

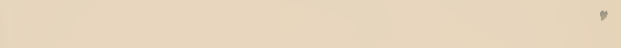

NUNC COGNOSCO EX PARTE

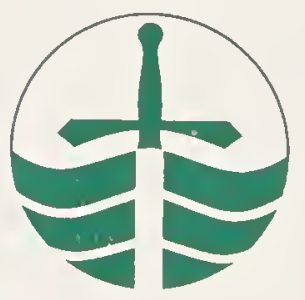

TRENT UNIVERSITY LIBRARY 


25

Pinkest

TWENTIETH CENTURY TEXTBOOKS EDITED BY

A. F. NiGHTINGale, Ph. D.

SUPERINTENDENT OF HIGH SCHOOLS, CHICAGO 

Digitized by the Internet Archive in 2019 with funding from Kahle/Austin Foundation 


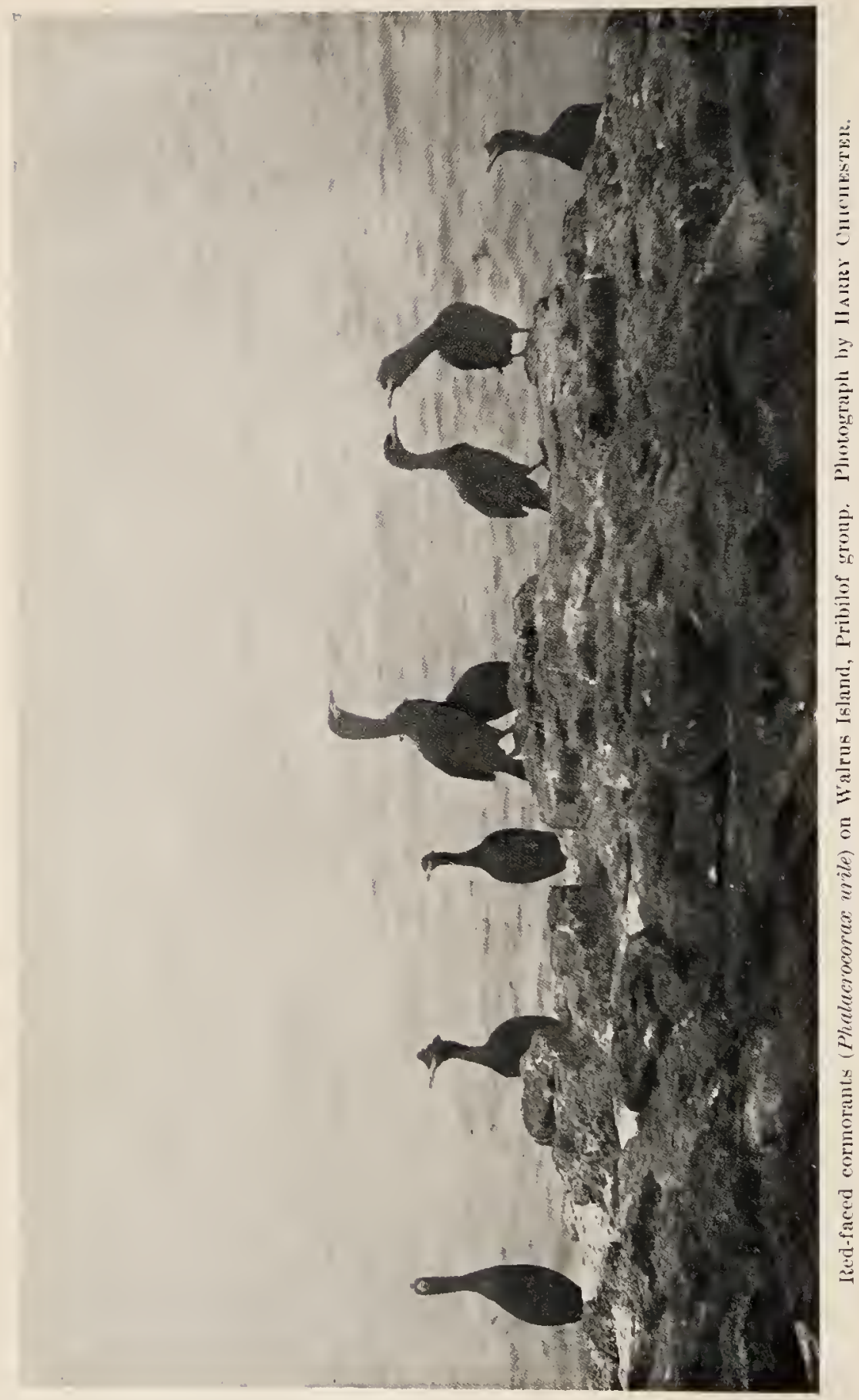




\section{A NIMAL LIFE}

A FIRST BOOK OF ZOÖLOGY

BY

DAVID STARR JORDAN. PH. D., LL. D.

PRESIDENT OF LELAND STANFORD JUNIOR UNIVERSITY

AND

VERNON L. KELLOGG, M. S.

PKOFESSOR IN I.ELAND STANFORD JUNIOR UNIVERSITY

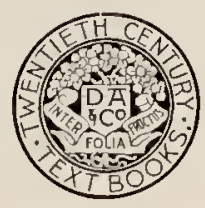

NEW YORK

D. APPLETON AND COMPANY

1900 
COPYRIGHT, 1900

BY D. APPLETON AND COMPANY 


\section{P R E F A C E}

THE authors present this book as an elementary account of animal ecology-that is, of the relations of animals to their surroundings and of the responsive adapting or fitting of the life of animals to these surroundings. The book treats of animals from the point of vicw of the observer and student of animal life who wishes to know why animals are in structure and habits as thcy arc. The beginning student should know that the whole life of animals, that all the varicty of animal form and habit, is an expression of the fitness of animals to the varicd circumstances and conditions of their living, and that this adapting and fitting of their life to the conditions of living come about incvitably and naturally, and that it can be readily studicd and largely understood. The ways and course of this fitting are the greatest facts of lifc cxcepting the fact of lifc itsclf. In this kind of study of animals crery obscrvation of a fact in animal structure or behavior lcads to a scarch for the significance, or meaning in the life of the animal, of this fact. The veriest beginner can be, and ought to bc, an indepcndent observer and thinker. It is the phase of the study of zoölogy which appeals most strongly to the beginning student, the phase which trcats of the why and how of animal form and habit. At the same time this phase is that to which the attention of the most advanced modern scholars of biology is rightly and chicfly turned. The 
point of vicw which the zoölogical beginner should take is the point of view that the best and most enlightened zoölogical scholar takcs. With this belief in mind the authors have tricd to put into simple form the principal facts and approved hypotheses upon which the modern conceptions of animal life are based.

It is mnecessary to say that this book depends for its best use on a basis of personal observational work by the student in laboratory and ficld. Without independent persollal work of the student little can be learned about animals and their life that will stick. But present-day teachers of biology are too well informed to make a discussion of the methods of their work necessary here. As a matter of fact, the mcthods of the teacher depend too nearly absolutely on his training and individual initiative to make worth while any attempt by the authors to point out the place of this book in elementary zoölogical teaching. That the phasc of study it attcmpts to represent should have a place in such teaching is, of course, firmly belicved by them.

'The obligations of the authors for the use of certain illustrations are acknowledged in proper place. Where no credit is otherwise given, the drawings have becn made by Miss Mary H. Wellman or by M[r. James Carter Bcard, and the photographs have bcen made by the authors or nnder their dircetion.

$$
\begin{aligned}
& \text { DAYTD STARR JORDAN, } \\
& \text { VIRNON LYMAN KELLOGg. }
\end{aligned}
$$

Stanford University, July, 1900. 


\section{CONTENTS}

CHAPTER

I.-THE LIFE OF THE SIMPLEST ANINALS .

The simplest animals, or Protozoa, 1.-The animal cell, 2.What the primitive eell can do, 5.-Amoba, 5.-Paramoeium, 9. -Vorticella, 12.-Marine P'rotozoa, 15.-Globigerina and Radiolaria, 16.-Antiquity of the Protozoa, 20.-The prinitive form, 20.- The prinitive but successful life, 21 .

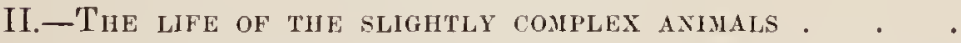

Colonial Protozoa, 24.-Gonium, 25.-T’andorina, 26.-Eudorina, 27.-Volvox, 28.-Steps toward complexity, 30.-Individual or colony, 31.-Sponges, 32.-Polyps, corals, and jelly-fishes, 37. -IIydra, 37.-Iifferentiation of the body cells, 41.-Neduse or jelly-tishes, 41.-Corals, 43.-Colonial jelly-fishes, 45.-Inerense in the degree of eomplexity, 48.

III.-THE MULTIPLICATION OF ANIMALS AND SEX .

All life from life, 50.-Spontaneous gencration, 51.-'The simplest method of multiplieation, 53.- Slightly eomplex methods of multiplieation, 54.-- Differentiation of the reproductive eclls, 55 . -Sex, or male and female, 57.-The object of sex, 57.-Sex dimorphism, 58.-The number of young, 61.

IV.-FUNCTION AND STRUCTURE . . . . . . .

Organs and functions, 63.-Differentiation of structure, 64.Anatomy and physiology, 64.-The animal boly a maehine, 65. - The specialization of organs, 66.-The alimentury cunal, 66.Stable and variable characteristies of an organ, 73. Stable and variable characteristics of the alimentary eanal, $73 .-$ The mutual relation of function and structure, 77 .

V.-ThE LIFE CTCLE . . . . . . . . .

Birth, growth and devclopment, and death, 78.--Life eyelc of simplest animals, 78.-The egg, 79.-Embryonic and post-embryonie development, 80.-Continuity of development, 83.-Development after the gastrula stage, 84.-Divergence of develop- 
ment, 84.-The laws or general ficts of development, 86.-The significumes of the facts of development, 89.-Netamorphosis, 90.-Metamorphosis among inseets, 90.-Metamorphosis of the toad, 94.-Metamorphosis among other animals, 96.-Duration of life, 101.-Death, 103.

VI.-THE PRIMARY CONDITIONS OF ANIMAL LIFE.

Primary conditions and speeial conditions, 106.-Food, 106.Oxygen, 107.-Temperature, pressure, and other eonditions, 108. -Difference between animals and plants, 111.-Living organie matter and inorganie matter, 11 .

VII.-ThE CROWD OF ANIMALS AND THE STRUgGle For ExISTENCE

The crowd of animals, 114.-The struggle for existence, 116. - Selection by Nature, 117.--Adjustment to surromdings a result of natural selection, 120.-Artificial selection, 120.-Dependence of species on species, 121.

VII.-ADAPTATIONS . . . . . . . . . .

Origin of adaptations, 128.-Classifiention of alaptations, 123. - Adaptations for securing food, 125.-Acaptations for self-chfense, 125.-Adaptations for rivalry, 135.-Adaptations for the defense of the young, 137.-Adaptations coneerned with surroundings in life, 143.-Degree of structural change in adaptations, 146.-Vestigrial organs, 147.

IX.-ANIMA, COMMUNTIES AND SOCIAL LIFE • • • .

Man not the only soeial animal, 148.-The honey-bee, 149.The ants, 155.-()ther communal insects, 158.- (ilegarionsmess atul mutual nid, 163.-1)ivision of labor and basis of communal life, 168.- Advantages of communal life, 170.

X.-COMMENSALISM AND STMBlosis . . . . . .

Assoeiation between aninals of different species, 172.-Commensalism, 173.-Symbiosis, 175 .

Ni.-Parasitisa ani megheration .

Relation of parasite and host, 179.-Kinds of parasitism, 190. -Tho simple structure of parasites, 181.-Gregarina, 182.-The tape-wom and other Hat-worms, 183.-Trichina and other roumeWu1ms, 184.-Sacenlina, 187.-Parasitie insects, 188.-l'arasitic vertebrates, 193.-Dugeneration through quiescence, 193.-Degeneration through other eanses, 197.--linmediate eauses of degeneration, 1 !19.- - Advantages and disalsantages of parasitism and degeneration, 198.-1luman degeneration, 200. 
Protective resemblance defined, 201.-General protective or agrossive resemblanee, 202.-Special proteetive resemblanee, 20\%.-Warning colors and terrifying appearances, 212.-Alluring coloration, 216.-Mimiery, 218.-Proteetive resemblanees and mimicry most common among inseets, 221.-No volition in mimiery, 222.-Color: its utility and beauty, 222.

XIII.-The SPECIAL SENSES . . . . . . . . .

Importance of the speeial senses, 224.-Diffieulty of the study of the special senses, 224. - Special senses of the simplest aninials, 225.-The sense of toueh, 226.-The sense of taste, 228.The sense of smell, 229.- The sense of hearing, 232.-Sound-making, 235 - The seuse of sight, 237.

XIV.-INSTINCT AND REASON . . . . . . . .

Irritability, 240-- Verve cells and fibers, 240.-The brain or sensorium, 241.-Peflex action, 241.-Instinet, 242.-Classification of instinets, 243.-Feeding, 244.--Self-defense, 245.-Play, 247.-Climate, 248.-Environment, 248.-Courtship, 248.-Reprocluction, 249.-Care of the young, 250.-Variability of instinets, 251.- Reason, 251.-Mind, 255.

XV.-IIONES AND DOMESTIC HABITS

Importance of eare of the young, 257.- rave of the young and eommunal life, 257.-The invertebrates (except spiders and inseets), 258.-Spiclers, 259.-Insects, 282.-The vertobrates, 261.

XVI.-Geographical distributiox of animals . . . .

Geographical distribution, 272.-Laws of distribution, 274.Speeies debarred by barriers, 274.- Speeies debarred by inahility to maintain their ground, 275. - Speeies altered by adaptation to new eonditions, 276. - Fffect of barriers, 283.-Relation of species to luabitat, 283.-Character of barriers to distribution, 288.- Barriers affecting fresh-water animals, 294.-Modes of distribution, 296.-Fauna and faunal areas, 296.-Reahns of animal life, 297.Subordinate reahms or provinees, 303.-Faunal areas of the sea, 304.

Classifichtion of animals . . . . . . 307

Glossary . . . . . . . . . . 313

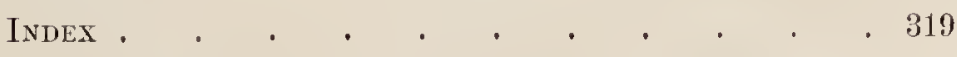





\section{ANTMAL LIFE}

\section{CHAPTER I}

\section{THE LIFE OF THE SIMPLEST ANIMALS}

1. The simplest animals, or Protozoa.-The simplest animals are those whose bodies are simplest in strueture and which do the things done by all living animals, sueh as eating, breathing, moving, feeling, and reprodueing in the most primitive way. The body of a horse, made np of various organs and tissues, is complexly formed, and the various organs of the body perform the various kinds of work for which they are fitted in a eomplex way. The simplest animals are all very small, and almost all live in the water; some kinds in fresh water and many kinds in the oeean. Some live in damp sand or moss, and still others are parasites in the bodies of other animals. They are not familiarly known to us; we ean not see them with the unaided eye, and yet there are thousands of diflerent kinds of them, and they may be found wherever there is water.

In a glass of watel taken from a stagnant pool there is a host of animals. There may be a few water beetles or water bugs swimming violently about, animals half an ineh long, with head and eyes and oar-like legs; or there may be a little fish, or some tadpoles and wrigglers. These are evidently not the simplest animals. There will be many very small aetive animals barely visible to the unaided eyes. These, too, are animals of eonsiderable complexity. But if a single drop of the water be plaeed 
on a glass slip or in a wateh glass and examined with a compound mieroseope, there will be seen a number of extremely small creatures which swim about in the water-drop by means of fine hairs, or erawl slowly on the surface of the glass. 'These are among our simplest animals. There are, as already said, many kinds of these "simplest animals," although, perhaps strietly speaking, only one kind can be called simplest. Some of these kinds are spherieal in shape, some elliptical or football-shaped, some conical, some flattened. Sone have many fine, minute hairs projecting from the surfaee; some have a few longer, stronger hairs that lash back and forth in the water, and some have no hairs at all. There are many kinds and they differ in size, shape, body eovering, manner of morement, and habit of food-getting. And some are truly simpler than others. But all agree in one thing-which is a very important thing-and that is in being composed in the simplest way possible anıong animals.

2. The animal cell.-The whole body of any one of the simplest animals or Protozoa is eomposed for the animal's whole lifetime of but a single cell. 'The bodies of all other animals are eomposed of miny eells. The eell may be ealled the unit of animal (or plant) strueture. The body of a horse is eomplexly composed of organs and tissues. Each of these organs and tissues is in turn eomposed of a large nunber of these structural units called eells. These cells are of great variety in slape and size and general character. The eells which compose museular tissue are very different from the eells which eompose the brain. And both of these kinds of eells are very different from the simple prinitive, molifferentiated kind of eell seen in the body of a protozoan, or in the earliest embryonie stages of a many-eelled animal.

The animal cell is rarely typieally cellular in eharaeter -that is, it is rarely in the condition of a tiny sae or box of synmetrical shape. Plant eells are often of this eliar- 
acter. The primitive animal cell (Fig. 1) consists of a small mass of a viscid, nearly colorless, substance called motoplesm. This protoplasm is differentiated to form two parts or regions of the cell, an inner denscr mass called the moleus, and an outer, clearer, inclosing mass called the cytoplasm. 'There may be more than one nucleus in a cell. Somctimes the cell is inclosed by a cell wall which may be simply a tougher onter layer of the cytoplasm, or may be a thin membrane secreted by the protoplasm. In addition to the protoplasm, which is the fundamental and cssential cell substance, the cell may contain certain so-called ccll products, substances produced by the life processcs of the protoplasm. The cell may thus contain water, oils, resin, starch grains, pigment gran-

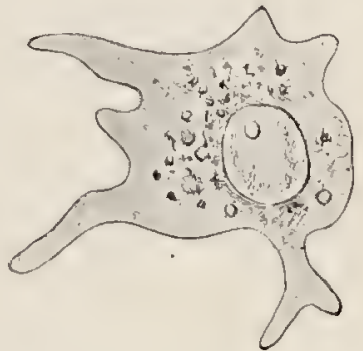

Fig. 1.-Blood cell of a crab (after HaEckel). Showing cy toplasm and nucleus (the large, inner, nearly circular spot) and granules of various substances lying in the cytoplasm. ules, or other substances. These substances are held in the protoplasm as liquid drops or solid particles.

'The protoplasm itsclf of the cell shows an obvious division into parts, so that certain parts of it, espccially parts in the nuclens, have received names. 'The nuclens usually has a thin protoplasmic membrane surrounding it, which is called the nurlear membrane. 'There appear to be fine threads or rods in the nucleus which are cvidently diffcrent from the rest of the nuclcar protoplasm. 'These rods arc called chromosomes. 'The cell is, indced, not so simple as the words "structural unit" might imply, but science has not yet so well analyzed its parts as to warrant the transfer of the name structural nnit to any single part of the cell-that is, to any lesser or simplcr part of the animal body than the cell as a whole.

The protoplasm, which is the cssential substance of the cell and hence of the whole animal body, is a substance 
of a very complex chemical and physical constitution. Its chemical structure is so complex that no chemist has yet been able to analyze it, and as the further the attempts at analysis reach the more complex and baffling the substance is found to be, it is not improbable that it may never be analyzed. It is a compound of numerous substances, some of these composing substances being themselves extremely complex. The most important thing we know about the chemical constitution of protoplasm is that there are always prescnt in it certain complex albuminous substances which arc never found in inorganic bodies. It is on the presence of these albuminous substances that the power of performing the processes of life depends. Protoplasm is the primitive basic life substance, but it is the presence of these complex albuminous componnds that makes protoplasm the life substance. A student of protoplasm and the fundamental life processes, Dr. Daverport, has said, "Just as the geologist is forced by the facts to assume a vast but not infinite time for earth building, so the biologist has to recognize an almost unlimited complexity in the constitution of the protoplasm." *

* The physieal structure of protoplasm has been mueh studied, but even with the improred microseopes and other instruments necessary for the study of minute structure, maturalists are still very far from understanding the physical constitution of this substince. While the alperance of protoplasm under the microseope is pretty generally ngreed on anong naturalists, the interpretation of the kind of strueture which is indicaterd by this appearanee is not at all well agreed on. P'rotoplasm inperars as a mesh work eomposed of fine granules suspencled in a clearer substance, the spaces of the mesh work being comfrosed of at third still clearer substance. Some naturalists believe, from this apearunce, that protoplasm is composed of a clear viseous subtance, in which are imbedrled many fine granules of denser substanee, and numerous large globules of a clearer, more liquid substance. Other maturalists believe that the fine spots which appear to be granules are simply cross sections of fine threals of dense protoplasm whieh lie coiled and tangled in the thinner, clearer protoplasm. And, finally, 
3. What the primitive cell can do.-The body of one of the minute animals in the water-drop is a single cell. The body is not composed of organs of different parts, as in the body of the horse. Tliere is no heart, no stomach; there are 110 muscles, no nerves. And yet the protozoan is a living animal as truly as is the horse, and it breathes and eats and moves and feels and produces young as truly as does the horse. It perfor'ms all the processes necessary for the life of an animal. 'The single cell, the single minute speck of protoplasm, has the power of doing, in a very simple and primitive way, all those things which are necessary for life, and which are done in the casc of other animals by the various organs of the body.

4. Amœba.-The simple and primitive life of these Protozoa can be best understood by the observation of living individuals. In the slime and sediment at the bottom of stagnant pools lives a certain specially interesting kind of protozoan, the Amoba (Fig. 2). Of all the simplest aninals this is as simple or primitive as any. The minute viscous particle of protoplasm which forms its body is irregular in outline, and its outline or shape slowly but constantly changes. It may contract into a tiny ball; it may become almost star-shaped; it may become elongate or flattened; short, blunt, finger-like projections called pscudopods extend from the central body mass, and these projections are constantly changing, slowly pushing out or

others believe that protoplasm exists as a foam work; that it is a viscous liqnid containing many fine glohules (the gramule-appearing spots) of a liquid of different density and numerous larger globules of a liquid of still other density. It is a foam in which the bubbles are not filled with air, but with liquids of different density. This last theory of the structure of protoplasn is the one accepted by a majority of modern naturalists, although the other theories have numerous believers. But just as with what little we know of the chemical constitution of protoplasm, the little we know of its physical structure throws almost no light on the remarkable properties of this fundamental life substance. 
drawing in. The single protoplasmic cell which makes up the body of the Amoba has no fixed outline; it is a cell without a wall. 'The substance of the eell or body is protoplasm, semiliquid and eolorless. The changes in form of the body are the moving of the Amoba. By close watehing. it may be seen that the Amceba ehanges its position on the glass slip. Althongh provided with no legs or wings or
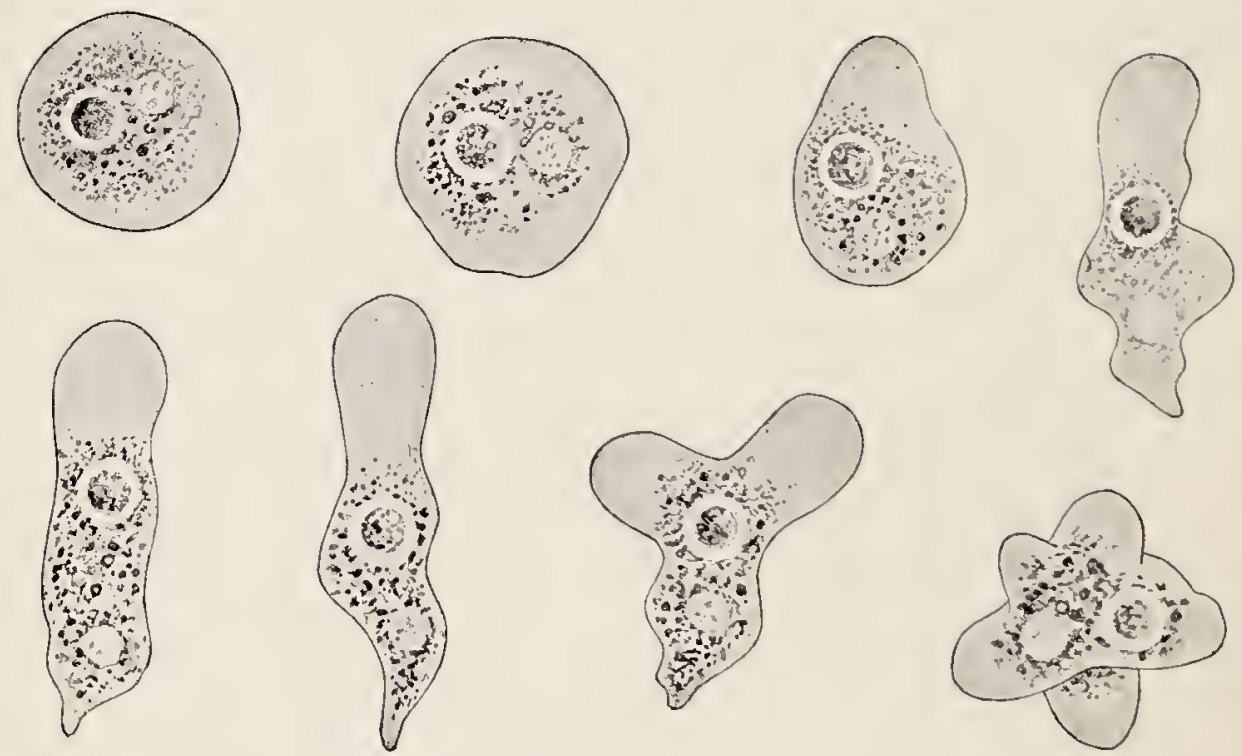

Fu. :- An Amobe, showing diflerent shapes assumed by it when crawling. - Mfler TERWORN.

scales or looks-that is, witl no special organs of locomotion-the Amerbe moves. 'There are no muscles in this tiny borly; miseles are composed of many contractile cells massed together, and the Ammba is but one eell. Bnt it is a eontratile cell ; it ean do what the muscles of the eomplex animals do.

If one of the finger-like projeetions of the Ameba, or, indeed, if any part of its body comes in eontatet witl some other mieroscopic :mimal or plant or some small fragment of a larger form, the soft body of the Imoba will be seen 
to press against it, and soon the plant or animal or organic particle becomes sunken in the protoplasm of the formless body and entirely inclosed in it (Fig. 3). 'The absorbed particle soon wholly or partly disappears. This is the manner in which the Amoba eats. It has no mouth or
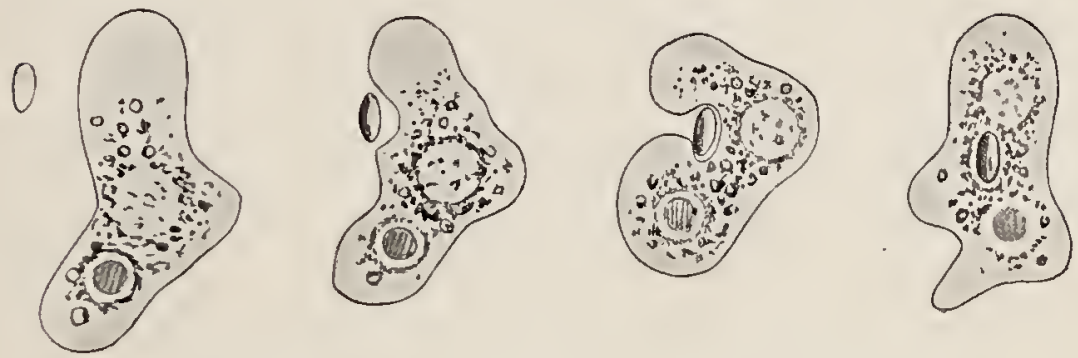

Frg. 3.-Amceba eating a microscopic one-celled plant.-After VERworn.

stomach. Any part of its body mass can take in and digest food. The viscous, membraneless body simply flows about the food and absorbs it. Such of the food particles as can not be digested are thrust out of the body.

The Amceba breathes. Though we can not readily observe this act of respiration, it is true that the Amoba takes into its body through any part of its surface oxygen from the air which is mixed with water, and it gives off from any part of its body carbonic-acid gas. Although the Amobe has no lungs or gills or other special organs of respiration, it breathes in oxygen and gives out carbonic-acid gas, which is just what the horse does with its elaborately developed organs of respiration.

If the Amreba, in moving slowly about, comes into contact with a sand grain or other foreign particle not suitable for food, the soft body slowly recoils and flows-for the movement is really a flowing of the thickly fluid protoplasm - so as to leave the sand grain at one side. 'The Amoba feels. It shows the effects of stimulation. Its movements can be changed, stopped, or induced by mechanical or chemical stimuli or by changes in temperature. The 
Amoba is irritable; it possesses irritability, which is sensation in its simplest degree.

If food is abundant the Amobre soon increases in size. The bulk of its body is bound to increase if new substance
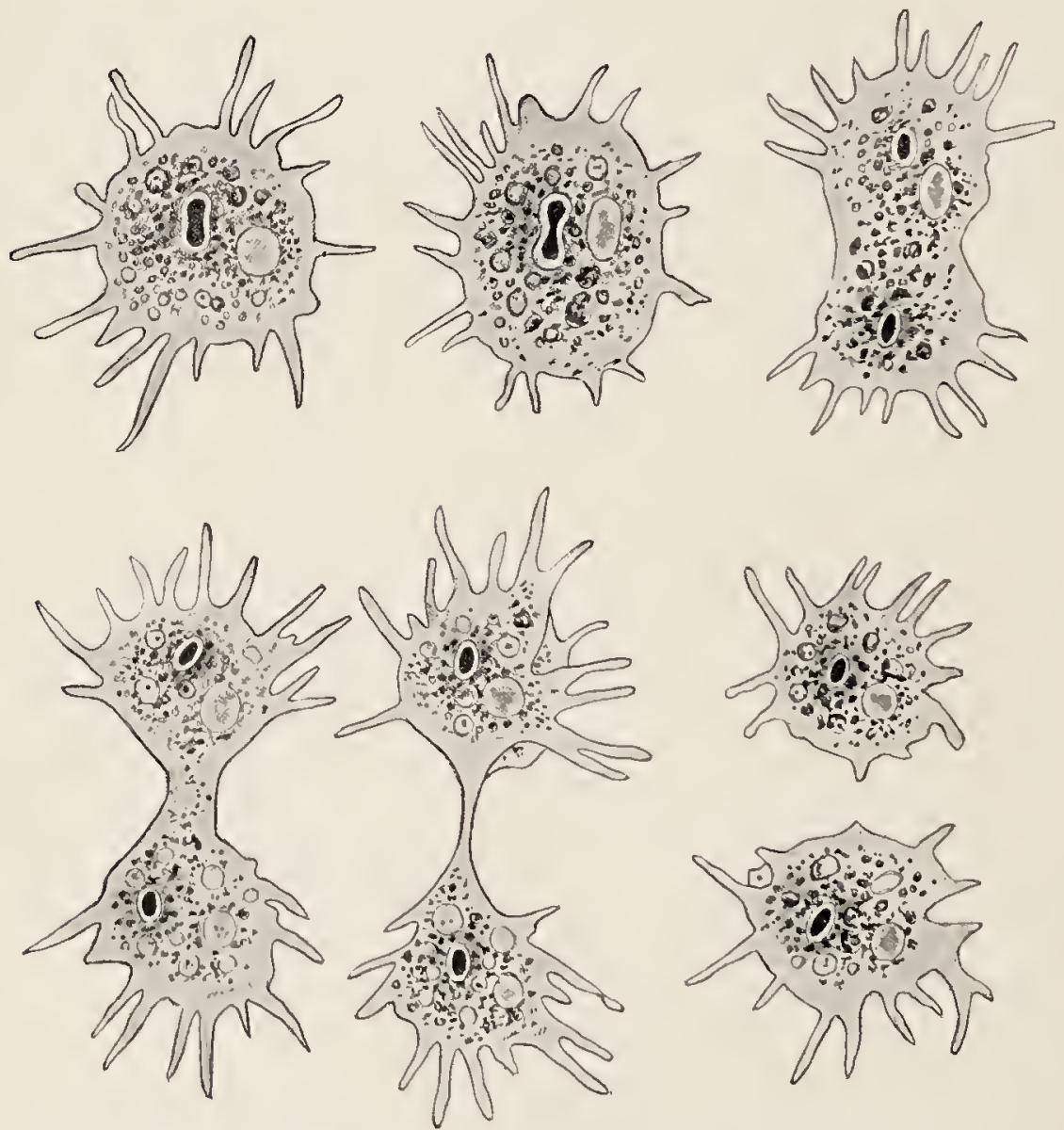

Fic. 4.- Imalon polyporta in six successive stages of division. The dark, whitematrined spot in the interior is the nucleas. After F. E. Schudze.

is constantly assimilated and added to it. The Ameba grows. But there seem to be some fixed limits to the extent of this inerease in size. No Amaba becomes large. A remarkable phenomenon always occurs to prevent this. 
An Amoba whieh has grown for some time eontrats all its finger-like proeesses, and its body beeomes eonstrieted. This eonstrietion or fissure inereases inward, so that the body is soon divided fairly in two (Fig. 4). The body, being an animal eell, possesses a nueleus imbedded in the body protoplasm or eytoplasm. When the body begins to divide, the nueleus begins to divide also, and beeomes entirely divided before the fission of the eytoplasm is eomplete. There are now two Amobe, eaeh half the size of the original one; eaeh, indeed, being aetually one half of the original one. 'This splitting of the body of the Amoba, whieh is ealled fission, is the proeess of reproduetion. The original Amoba is the parent; the two halves of the parent are the young. Eaeh of the young possesses all of the eharaeteristies and powers of the parent; each ean move, eat, feel, grow, and reproduee by fission. It is very evident that this is so, for any part of the body or the whole body was used in performing these funetions, and the young are simply two parts of the parent's body. But if there be any doubt about the matter, observation of the behavior of the young or new Amobe will soon remove it. Eaeh puts out pseudopods, moves, ingests food partieles, avoids sand grains, eontraets if the water is heated, grows, and finally divides in two.

5. Paramœcium.-Another protozoan whieh is eommon in stagnant pools and ean be readily obtained and observed is Paramocium (Fig. 5). The body of the Paramocium is mueh larger than that of the Amoba, being nearly one fourth of a millimeter in length, and is of fixed shape. It is elongate, elliptieal, and flattened, and when examined under the mieroseope seems to be a very eomplexly formed little mass. The body of the Paramecium is indeed less primitive than that of the Ameba, and yet it is still but a single eell. The protoplasm of the body is very soft within and dense on the outside, and it is eovered externally by a thin membrane. The body is eovered with short fine hairs or eilia, 
which are fine proeesses of the dense protoplasm of the surfaee. There is on one side an oblique shallow groove that leads to a small, fmmel-shaped depression in the body which serves as a primitive sort of mouth

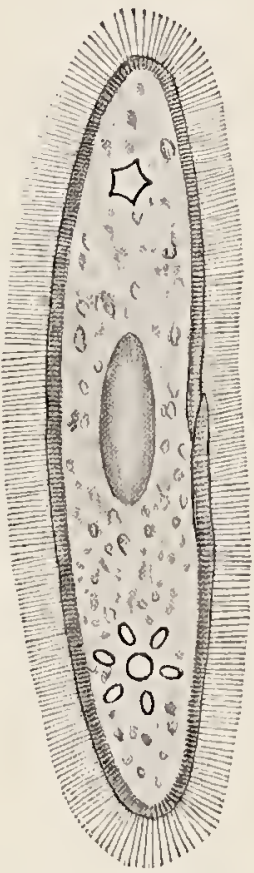

Fia. 5.-Peramerimm ausvelive (after Verwolis). At each culd there is a contractile vacuole, and in the center is one of the unclei. or opening for the ingress of food. The Paramacium swims about in the water by ribrating the cilia which eorer the body, and brings food to the mouth opening by producing tiny eurrents in the water by means of the eilia in the oblique groove. The food, which eonsists of other living Protozoa, is taken into the body mass only through the funnel-shaped opening, and that part of it whieh is undigested is thrust ont always through a particular part of the body surface. (The taking in and ejecting of foreign particles can be seen by putting a little powdered earmine in the water.) Within the body there are two nnclei and two soealled pulsating vacuoles. These pulsating vacuoles (Amcebr has onc) secm to aid in discharging waste produets from the body. When the l'aramorimm tonches some foreign substanee or is otherwise irritated it swims away, and it shoots ont from the surfaee of its body some fine long threals which when at rest are probably coiled up in little saes on the surface of the body. When the Paramerium has taken in enough food and grown so that it has reaehed the limit of its size, it divides transversely into halves as the Amolua does. Both nuelei divide first, and then the cytoplasm constriets and divides (Fig. 6). 'Thus two new P'armocia are formed. Onc of them has to develop a new month opening and groove, so that there is in 
the ease of the reproduction of Paramcecium the beginnings of developmental changes during the course of the growth of the young. The young Amobe have only to add substance to their bodies, to grow larger, in order to be exactly like their parent.

The new Paramecia attain full size and then divide, each into two. And so on for many generations. But it has been diseovered that this simplest kind of reproduction can not go on indefinitely. After a number of generations the Paramceria, instead of simply dividing in two, come together in pairs, and a part of

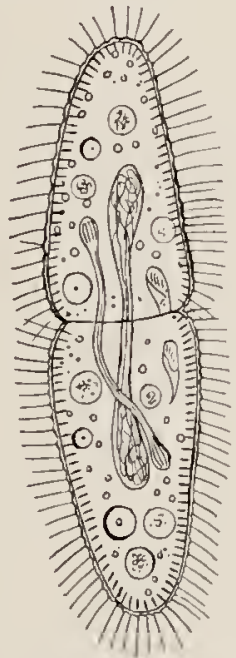

FI:. 6.-Paramacium putorinun dividing. The two nuclei becone very elongate before dividing.-After BÜtscut. one of the nuclei of each member of a pair passes into the body of and fuses with a part

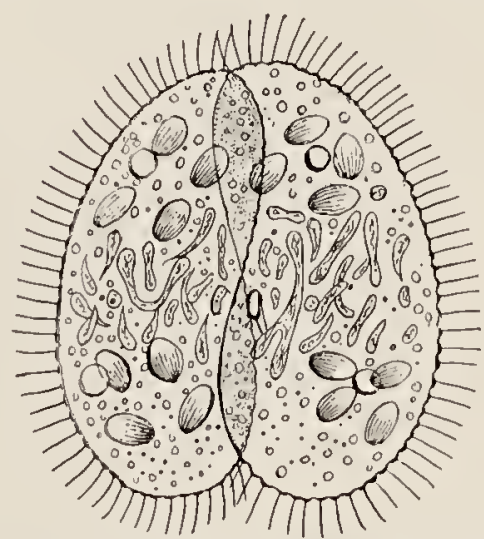

Fur, :- Paramarium coullatum ; two individuals separatiug after conjugation.

of one of the nuelei of the other member of the pair. In the meantime the seeond nucleus in each Paramocinm has broken up into small pieces and disappeared. The new nucleus composed of parts of the unclei from two animals divides, giving eaeh animal two nuelei just as it had beforc this extraordinary proeess, which is called conjugation, began (Fig. \%). Each Parancecium, with its nuelei composed of parts of the nuelei from two distinet individuals, 
now simply divides in two, and a large number of generations by simple fission follow.

Paramocium in the eharacter of its body and in the manner of the performance of its life processes is distinctly less simple than the Amoba, but its body is composed of a single struetural unit, a single eell, and it is truly one of the "simplest animals."

6. Vorticella.-Another interesting and readily found protozoan is Vorticelle (Fig. 8). While the Amoba can erawl and Paramocium swim, Vorticella, exeept when very young,
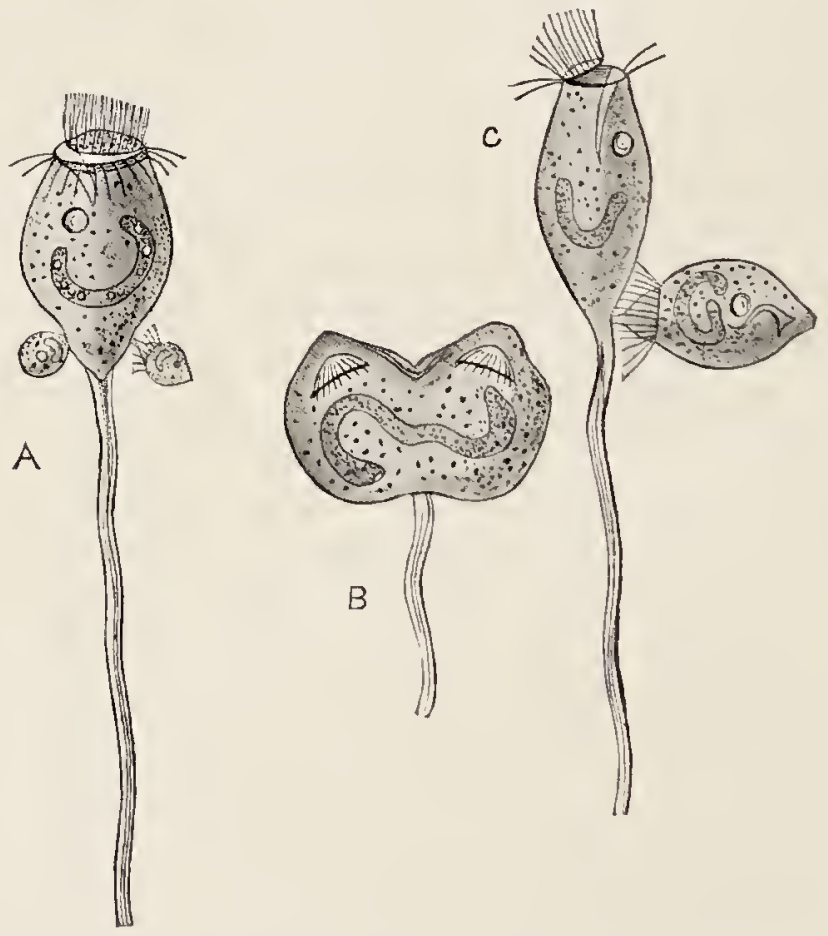

Fu. 8.- Forticelle microstoma (after STE1N), A, small, free-swimming indivlduals conjugating with a latge, stalked individual; $B$, a stalked individual diveding longitudinally; $\mathrm{c}$, after division is completed one part severs itself from the other, forms a ring of cilia, and swims away.

is attached by tiny stems to dead leaves or sticks in the water, and ean ehange its position only to a limited extent. 
The body is pear-shaped or bell-shaped, with a mouth opening at the broad end, and a delicate stem at the narrow end. This stem is either hard and stiff, or is flexible and capable of being suddenly contracted in a close spiral. In the body mass there is one pulsating vacuole and one nucleus. Usually many Vorticellee are found together on a common stalk, thus forming a protozoan colony.

The life processes of Vorticella are of the simple kind already observed in Amoba and Parameecium. Vorticella shows, however, some modifications of the process of reproduction which are interesting. The plane of division of Vorticelle is parallel to the long axis of the pear-shaped body, so that when fission is complete there are two Vorticellce on a single stalk. One of the two becomes detached, and by means of a circle of fine hairs or cilia which appear around its basal end leads a free swimming life for a short time. Finally it settles down and develops a stalk. Vorticella shows two kinds of fission-one the usual division into equal parts, and another division into unequal parts. In this latter kind, called reproduction or multiplication by budding, a sinall part of the parent body separates, develops a basal circle of cilia, and swims away. The process of conjugation also takes place among the Vorticella, but they are never two equal forms which conjugate, but always one of the ordinary stalked forms and one of the small free-swimming forms produced by budding.

Here, then, in the life of Vorticella, are new modifications of the life processes; but, after all, these life processes are very simply performed, and the body is like the body of the Amoba, a single cell. Vorticella is plainly one of "the simplest animals."

7. Gregarina. - A fourth kind of protozoan to which we can profitably give some special attention is Gregarina (Fig. 9), the various species of which live in the alimentary 
canal * of crayfishes and centipeds and certain insects. Gregarina is a parasite, living at the expense of the host in whose body it lies. It has no need to swim about quickly,
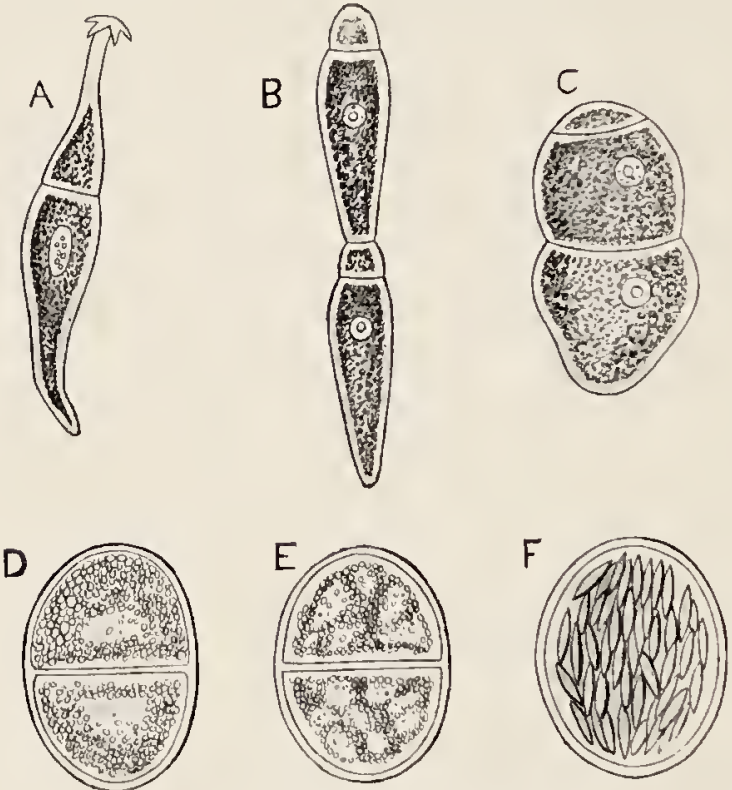

Fur. 9.-Gregarinide. A, a Gregarinid (Actinocephalus oligacanthus) from the intestine of an insect (aftor STwiN) : $\mathrm{B}$ and $\mathrm{C}$, spore forming by a cregarinid (Coccidium oviforme) from the liver of a guinea-pig (after LevckanT); D, E, and F, successive stuges in the eonjugation and spoce forming of Cregarina polymompha (after KOELLAKEL).

and hence has no swimming cilia like Paramecium and the young Vorticella. It docs need to cling to the inner wall of the alimentary canal of its host, and the body of some spceies is provided with hooks for that purpose. The

* Specimens of Gregarina can be abundantly found in the alimentary canal of meal worms, the larva of the black beetle (Tenebrio molitor), common in granaries, mills, and brans. "Snip off with small scissors both ends of a larva, seize the protruding (white) intestine with forceps, draw it out, and tease a portion in normal salt solution (water will do) on a slide. Cover, find with the low power (minute, oblong, transparent bodies), and study with any higher objective to suit." MurBaCH. 
food of Gregarina is the liquid food of the host as it exists in the intestine, and which is simply absorbed anywhere through the surface of the body of the parasite. There is no mouth opening nor fixed point of ejection of waste material, nor is there any contractile vacuole in the body.

In the method of multiplication or reproduction Gregarina shows an interesting difference from $A m x b a$ and Paramocium and Vorticella. When the Gregarina is ready to multiply, its body, which in most species is rather elongate and flattened, contracts into a ball-shaped mass and becomes encysted-that is, becomes inclosed in a tough, membranous coat. This may in turn be covered externally by a jelly-like substance. The nucleus and the protoplasm of the body inside of the coat now divide into many small parts called spores, each spore consisting of a bit of the cytoplasm inclosing a small part of the original nucleus. Later the tough outer wall of the cyst breaks and the spores fall out, each to grow and devclop into a new Gregarina. In some species there are fine ducts or canals leading from the center of the cyst through the wall to the outside, and throngh these canals the spores issue. Sometimes two Gregarince come together before encystation and become inclosed in a common wall, the two thus forming a single cyst. This is a kind of conjugation. In some spccies each of the young or new Gregarince coming from the spores immediately divides by fission to form two individuals.

8. Marine Protozoa.-If called upon to name the characteristic animals of the ocean, we answer readily with the names of the better-known ocean fishes, like the herring and cod, which we know to live there in enormous numbers; the seals and sea lions, the whales and porpoises, those fish-like animals which are really more like land animals than like the true fishes; and the jelly-fishes and corals and star-fishes which abound along the occan's edge. But in naming only these we should be omitting certain animals which in point 
of abundanee of individuals vastly outnumber all other animals, and which in point of importance in helping maintain the eomplex and varied life of the oeean distinetly outelass all other marine forms. These animals are the marine Protozoa, those of the "simplest animals" which live in the ocean.

Although the water at the surface of the oeean appears elear, and on superfieial examination devoid of life, yet a drop of this water taken from certain oeean regions examined under the microseope reveals the fact that this water is inhabited by Protozoa. Not only is the water at the very surface of the oeean the home of the simplest animals, but they can be found in all the water from the surfaee to a great depth beneath it. In a pint of this ocean water from the surface or near it there may be millions of these animals. In the oceans of the world the number of them is inconceivable. Dr. W. K. Brooks says that the "basis of all the life in the modern ocean is found in the microorganisms of the surfaee." By micro-organisms he means the one-celled animals and the one-celled plants. For the simplest plants are, like the simplest animals, oneeelled. "Modern microscopieal research," he says, "has shown that these simple plants, and the Globigerine and Radiolaria [kinds of Protozoil] which feed npon them, are so abundant and prolifie that they meet all demands and supply the food for all the animals of the ocean."

9. The Globigerinæ and Radiolaria.-The Globigerinie (Fig. 10) and Raudiolaria (Fig. 11) are among the most interesting of all the simplest animals. Their simple oneeelled body is surrounded by a microseopie shell, whieh among the Globigerina is usually male of lime (calcium earbonate), in the ease of Radiolaria of siliea. 'These minute shells present a great variety of shape and pattern, many being of the most exquisite symmetry and beauty. The shells are usually perforated by many small holes, through whieh project long, delicate, protoplasmic threads. These 
fine thrcads interlace when they touch each other, thus forming a sort of protoplasmic network outside of the shell. In some cases there is a complete layer of protoplasmpart of the body protoplasm of the protozoan - surronnd-

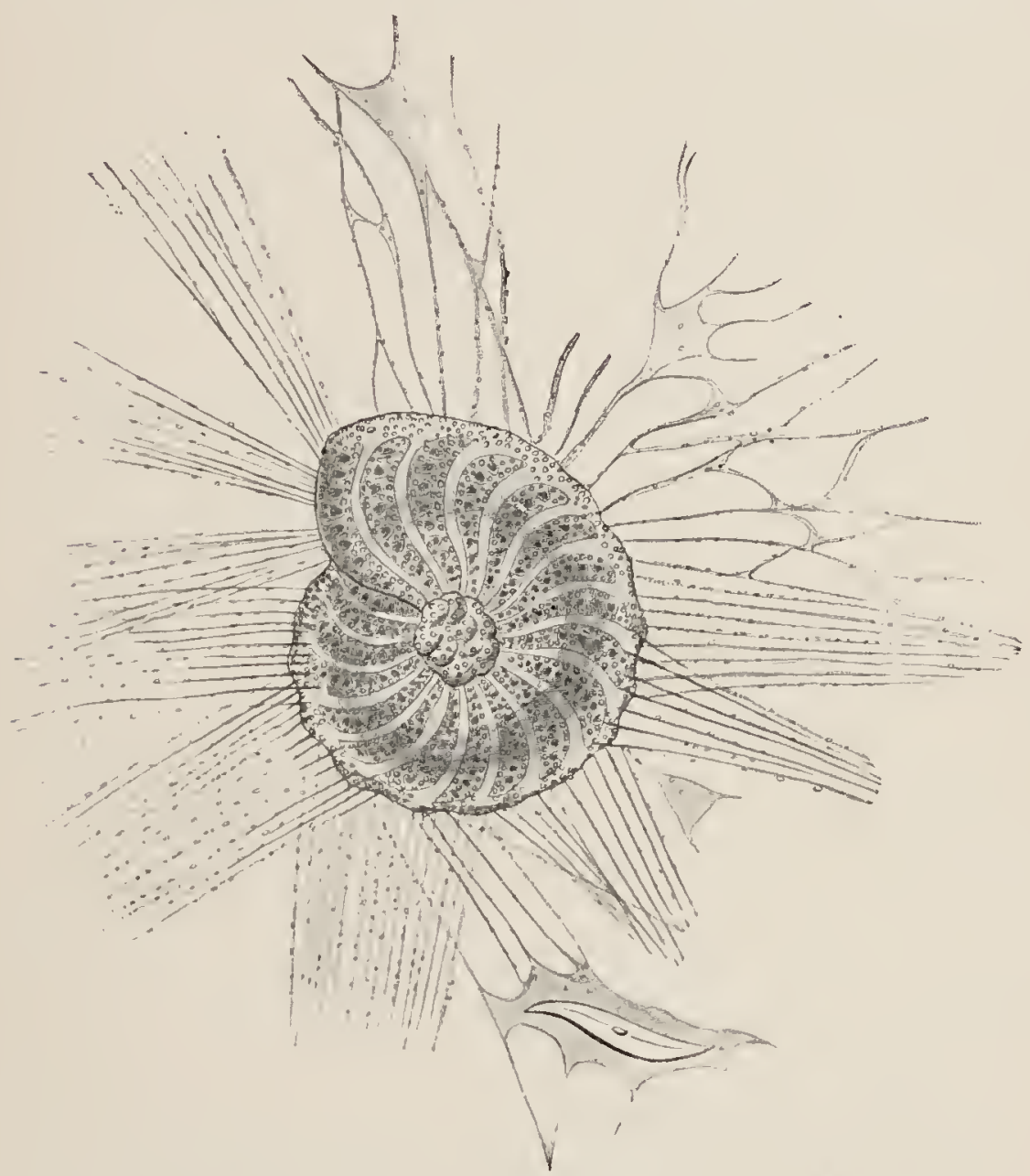

Fra. 10.-Polystomella strigillata, one of the Globigerine.-After Max Sonultze.

ing the cell externally. The Radiolaria, whose shclls are made of silica, possess also a perforated membranous sac called the central capsule, which lies imbedded in the protoplasm, dividing it into two portions, one within and 
one outside of the eapsnle. In the protoplasm inside of the eapsule lies the nueleus or nuclei; and from the protoplasm outside of the eapsule rise the numerous fine, threadlike pseudopods which project through the apertures in the shell, and enable the animal to swim and to get food.

Most of the myriads of the simplest animals which swar'm in the surfaee waters of the oeean belong to a few kinds of these shcll-bearing Globigcrinæ and Radiolaria. Large areas of the bottom of the Atlantic Oeean are corercd with a slimy gray mud, often of great thickness, which is ealled globigerina-ooze, beeause it is made up ehiefly of the mieroscopie shells of Globigerinæ. As death comes to the minute protoplasmic animals their hard shells sink slowly to the bottom, and aeeumulate in sueh rast quantities as to form a thiek layer on the oeean floor. Nor is it only in present times and in the oeeans we know that the Globigerine have flourished. All over the world there are thiek rock strata which are eomposed ehiefly of the fossilized shells of these simplest animals. Where the strata are made np exclnsively of these shells the roek is ehalk. Thus are eomposed the great ehalk elifts of Kent, which gave to England the early name of Ilbion, and the ehalk beds of France and Spain and Greece. The existenee of these ehalk strata means that where now is land, in earlier geologie times were oceans, and that in the occans Globigerine lived in combless numbers. Dying, their shells accumulated to form thiek layers on the sea bottom. In later geologie ages this sea bottom has been mplifted and is now land. far perhaps from any ocean. 'The ehalk strata of the plains of the Inited States, like those in Kansas, are more than a thousand miles from the sea, and yet they are mainly composed of the fossilized shells of marine Protozoa. Indeed, we are acquainted with more than twice as many fossil speeies of Globigrerina as species living at the present time. The ancestors of these Globigerina, from which the present Globigerine differ but little, can be 
traeed far baek in the geologie history of the world. It is an aneient type of animal strueture.

The Radiolaria, too, which live abundantly in the present oeeans, especially in the marine waters of the tropieal and temperate zolles, are found as fossils in the roeks from the time of the eoal age on. The silieeous shells of the

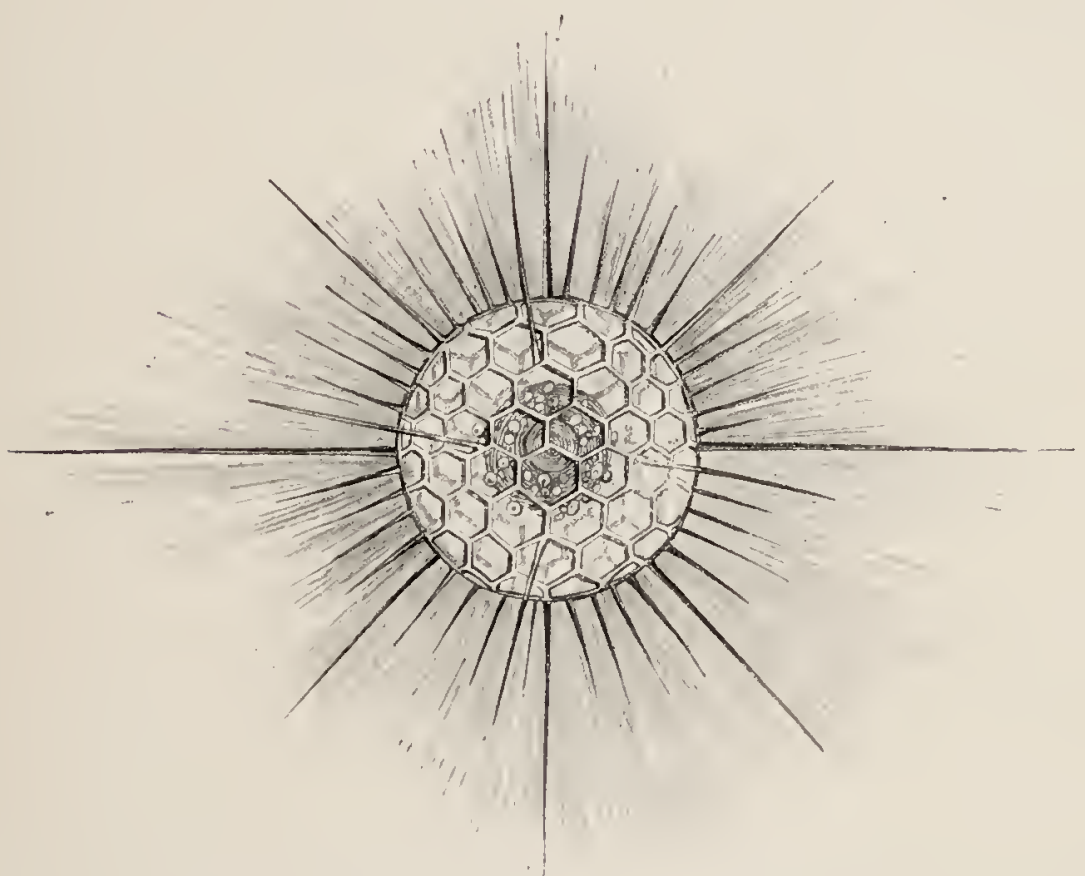

Fra. 11.-Deliosphera actinota (after IlAECKEL); a radiolarian with symmetrical shell.

Radiolaria sinking to the sea bottom and areumulating there in great masses form a radiolaria-ooze similal to the globigerinæ-ooze; and just as with the Globigerina, the remains of the aneient Radiolaria formed thiek layers on the floor of the aneient oeeans, which have sinee been uplifted and now form eertain rock strata. That kind of roek ealled Tripoli, found in Sieily, and the Barbatos earth from the island of Barbados, both of which are used 
as polishing powder, are composed almost exelusively of the siliceous shells of ancient and long-extinet Radiolaria.

10. Antiquity of the Protozoa.-All the animals of the ocean depend upon the marinc Protozoa (and the marine Protophyta, or one-eelled plants) for food. Either they prey upon these one-eelled organisms directly, or they prey upon animals which do prey on these simplest animals. The great zoölogist already quoted says: "The food supply of marine animals consists of a few speeies of mieroscopic organisms which are inexhaustible and the only source of food for all the inhabitants of the occan. The supply is primeval as well as inexhaustible, and all the life of the ocean has gradually taken shape in direct dependenee upon it." That is, the marine simplest animals are the only marine animals which live independently; they alone ean live or conld have lived in earlier ages withont depending on other animals. They must thercfore be the oldest of marine animals. By oldest we mean that their kind appeared earliest in the history of the world. As it is certain that marine life is older than terrestrial life-that is, that the first animals lived in the ocean-it is obvious that the marine Protozon are the most ancient of animals. This is an important and intcresting faet. Zoülogists try to find out the relationships and the degrees of antiquity or modernness of the varions kinds of animals. We have seen that the Protozoa, those animals whieh have the simplest body structure and perform the necessary life processes in the simplest way, are the oldest, the first animals. This is just what we would expeet.

11. The primitive form. - We find among the simplest animals a considcrable varicty of shape and some manifest variation in habit. But the points of rescmblance are far more pronounced than the points of difference, and are of fundamental importanee. The composition of the body of one cell, as opposed to the many-celled structure of the bodies of all other animals, is the faet to be most distinetly 
emphasized. The shape of this one-celled body varies. With the most primitive or simplest of the "simplest animals," like Amoba, for example, there is no "distinction of ends, sides, or surfaces, such as we are familiar with in in the higher animals. Anterior and posterior ends, right and left sides, dorsal and ventral snrfaces are terms which have no meaning in reference to an Amoba, for any part of the animal may go first in locomotion, and when crawling the animal moves along on whatever part of its surface happens to be in contact with foreign bodies." The one shape most often seen among the Protozoa, or most nearly fairly to be called the typical shape, is the spherical or subspherical shape. Why this is so is readily seen. Most of the Protozoa are aqnatic and free swimming. They live in a medium, the water, which supports or presses on the body equally on all sides, and the body is not forced to assume any particular form by the environment. The body rests suspended in the water with any part of its snrface nppermost or any part undermost. As any part of the snrface serves equally well in many of the Protozoa for breathing or eating or excreting, it is obvious that the spherical form is the simplest and most convenient shape for such a body. It is interesting to note that the spherical form is the common shape of the egg cell of the higher animals. Each one of the higher, mnlticellular animals begins life (as we shall find it explained in another chapter of this book) as a single cell, the egg cell, and these egg cells are isually spherical in shape. The fnll significance of this we need not now attempt to muderstand, but it is interesting to note that normally the whole body of the simplest animals is a single spherical cell, and that every one of the higher animals, however complex it may become by growth and development, begins life as a single spherical cell.

12. The primitive but successful life-Living consists of the performing of certain so-called life processes, such as 
eating, breathing, feeling, and multiplying. These processes are performed among the higher animals by rarious organs, special parts of the body, each of which is fitted to do some one kind of work, to perform some one of these proeesses. 'There is a division or assignment of labor here among different parts of the body. Such a division of labor, and special fitting of different parts of the body for special kinds of work does not exist, or exists only in slightest degree among the simplest animals. The Amcor eats or feels or moves with any part of its body; all of the body exposed to the air (air held in the water) breathes; the whole body mass takes part in the process of reproduetion.

Only very small organisms ean live in this simplest way. So all of the Protozoa are minute. When the only part of the body which can absorb oxygen is the simple external surface of a spherical body, the mass of that body must be very small. Nith any increase in size of the animal the mass of the body increases as the cube of the diameter, while the surface increases only as the sqnare of the diameter. 'Therefore the part of the body (inside) whieh requires to be provided with oxygen increases more lapidly than the part (the outside) which absorbs oxygen. 'Thus this need of oxygen alone is suflicient to determine the limit of size which ean be attained by the spherical or subspherical Protozoa.

'That the simplest animals, despite the laek of organs and the primitive way of performing the life proeesses, live stecessfully is evident from their existence in such extraordinary numbers. 'They ontunmber' all other animals. Althongh serving as food for hosts of ocean animals, the marine l'rotozoa are the most abmondant in individuals of all living animals. The conditions of life in the surfaee waters of the ocean are easy, and a simple strueture and simple method of performanee of the life proeesses are wholly adequate for sueeessful life under these eonditions. 
That the character of the body structure of the Protozoa has changed but little since early geologic times is explained by the even, mnchanging character of their surroundings. The oceans of former ages have undoubtedly been essentially like the oceans of to-day-not in extent and position, but in their character of place of habitation for animals. The environment is so simple and uniform that there is little demand for diversity of habits and consequent diversity of body structure. Where life is easy there is no necessity for complex structure or complicated habits of living. So the simplest animals, unseen by us, and so inferior to us in elaborateness of body structure-and habit, swarm in comntless hordes in all the oceans and rivers and lakes, and live successfully their simple lives. 


\section{CHAPTER II}

\section{THE LIFE OF THE SLIGHTLY COMPLEX ANIMALS}

13. Colonial Protozoa. When one of the simplest animals multiplies by fission, the halves of the one-celled body separate wholly from each other, more apart, and pursue their lives independently. The original parent eell divides to form two eells, which exist thereafter wholly apart from each other. There are, however, certain simple animals which are classed with the Protozoa, which show an interesting and important difference from the great majority of the simplest animals. These are the so-called eolony-forming or colonial Protozoa.

These colonial Protozoa belong to a group of organisms called the * Volvocina. The simplest of the Volvocina are single cells, which live wholly independently and are in structure and habit essentially like the other Protozoa we have studied. They have, however, imbedded in the onecelled body a bit of chlorophyll, the green substance which gives the color to green plants and is so important in their physiology. In this respect they differ from the other Protozoa. Among the other Tolvocme, however, a few or many cells live together, forming a small eolony-that is,

* These colonial organisms, the Volvocina, are the oljects of some contention between botanists ancl zoölogists. The botanisls call them plants beranse they posises a cellnlose membrane and green chromatophores, and exhibit the motabolism characteristic of most plants ; but most zoölogists consider them to be animals belonging to the order Flagellata of the Protozon. In the latest anthoritative text-book of zoölogy, that of Parlier and llaswell (1897), they are so classed. 
there is formed a group of a few or many cells, each cell having the structurc of the simpler unicellular forms. These cells are held together in a gelatinous envelope, and the mass is usually spherical in shape. In most of the colonies each of the cells possesses two or three long, protoplasmic, whiplash-like hairs, called flagella, and by the lashing of these flagclla in the watcr the wholc group swims about.

14. Gonium.-If when one of the simplest animals divided to form two daughter cells, these two cells did not morc apart, but remained side by side and cach divided to form two more, and each of these divided to form two more, and these cight divided cach into two, each cell connplcte and independent but all remaining together in a group - if this process should take place we should have produced a group or colony of sixtecn cclls, cach cell a complcte animal capible of living indepcndently like the other simplest animals, but all holding together

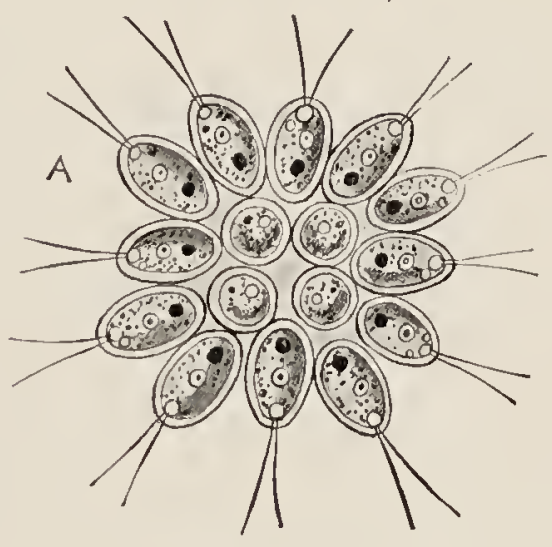
to form a tiny, flat, platelike colony. Now, this is precisely what takes place

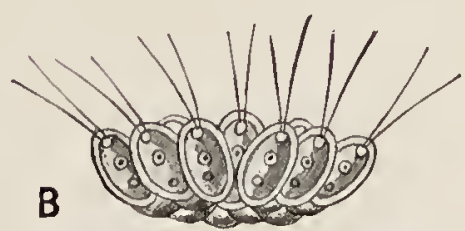

Fis. 12.-fionium pectorale (after ŚTE1N). A, colony seen from above; $\mathrm{B}$, colony seen from the side.

in the case of those colonial Protozoa belonging to the genus Gonium (Fig. 12). When the mother cell of (ionium divides, the daughter cells do not swim apart, but remain side by side, and by repcatcd fission, until thcre are sixteen cells side by side, the colony is formed. Each cell of the 
eolony eats and breathes and feels for itself; eaeh can and does perform all the proeesses necessary to keep it alive. When ready to multiply, the sixteen eells of the Gonium eolony separate, and eaeh eell becomes the aneestor of a new eolony.

15. Pandorina.-Another eolony usually eomposed of sixteen eells is Pandorina, but the eells are arranged to form a spherieal instead of a plate-like eolony (Fig. 13). In Pandorine morum the eolony consists of sixteen ovoid eells in a spherical jelly-like mass. Eaeh eell has two flagella, and by the lashing of all the flagella the whole eolony moves through the water. Food is taken by any of the eells, is assimilated, and the eells inerease in size. When Pandorina is ready to multiply, each eell dirides repeatedly until it has formed sixteen daughter eells. The inelosing gelatinous mass whieh holds the eolony together dissolves,

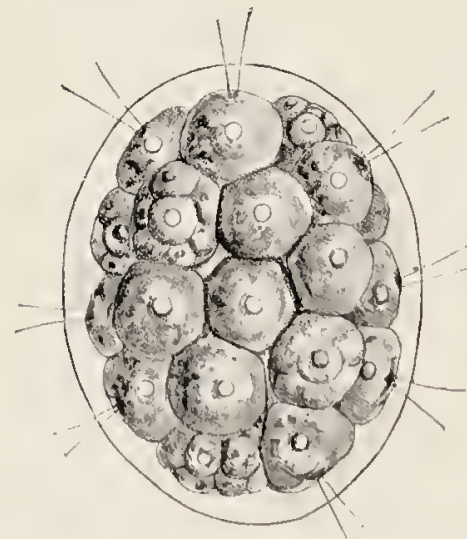

Fı, 13.-Pandorina s)). (from No tore), The cells composing the colony are hegiming to divide to form danghter colonies. and the damghter eolonies become free and swim apart. Each eolony soon grows to the size of the original eolony. This kind of multiplication or reproduetion may be eontinued for sereral generations. But it does not go on indefinitely. After a number of these generations have been produeed by simple division, the eells of a eolony divide each into eight instead of sixteen danghter eells. The daughter eclls are not all of the same size, but the differenee is hardly notieeable. 'The eight eells resulting from the repeated division of one of the original cells separate and swim about independently by means of their flagella. If one of these eells eomes near a similar frec-swimming eell from another 
colony, the two cells conjugate (Fig. 14) -that is, fusc to form a singlc eell. 'This new cell formed by the fusion of two, develops a tough enveloping membrane (of cellulosc) and passes into what is called the "resting stage." That is, the cell remains dormant for a shorter or longer time. It may thus tide over a drought or a winter. It may become dry or be frozen, yet when suitable eonditions of moisture or temperature arc again prescnt the outer wall breaks and the protoplasm issues as a large freeswimming cell, which soon divides into sixteen daughter cells which constitute a new eolony.

16. Eudorina. - Another eolonial protozoan which much resembles Pandorina, but difters from it in one interesting and A

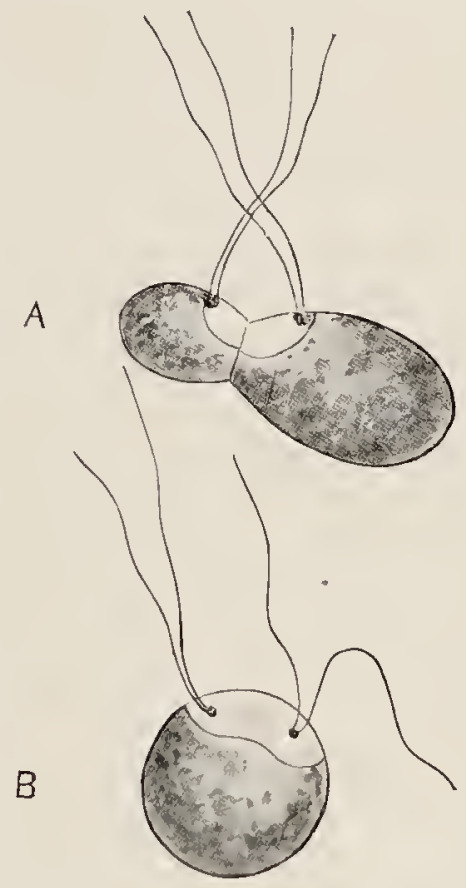
suggestive thing, is Eudoriua. In Eudorina elegens (Fig. 15) the eolony is spherieal and is eomposed of sixtecn ol thirtytwo eells. Eaeh of these cells can bccome the parcnt of a ncw colony by simple repeated division. But this simple mode of reproduction, just as with $P(n)-$ dorina, ean not persist indefinitcly. There must be eonjugation. But the process of mul-

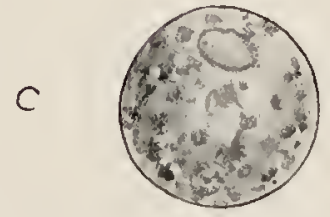

FIG. 14. - Pandonina morum (after GOEBEI ). Three stages in the conjugation and formation of the resting spore. A, two cells just fused: $B$, the two cells completely fused, but with flagella still persisting ; $\mathrm{C}$, the resting spore.

tiplieation, which includes conjugation, is different from that proeess in Pandorina, in that in Eudorina the conju- 
gating cells are of two distinctly different kinds. When this kind of multiplication is to take place in the case of Eudorina elegans, to choose a common species, some of the cells of a colony divide into sixteen or thirty-two

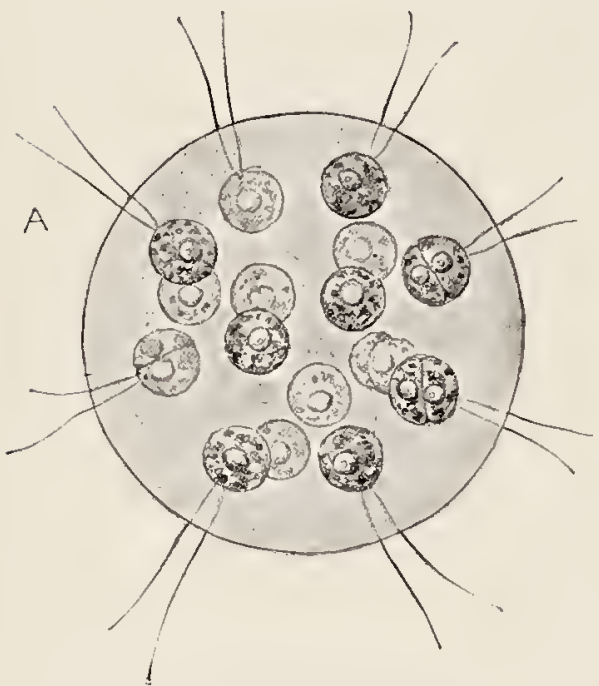
minute elongated cells, each provided with two flagella. These small cells escape

Fis. 15.-Eudorina elegans. A, a mature colony (from Nature); B, formation of the two kinds of reproductive cells.

from the envelope of the parent cell, remaining for some time united in small bundles. Other cells of the colony do not divide, but increase slightly in size and become spherical in shape. When a bundle of the small cells comes into contact with some of these large spherical cells the bundle breaks up, and conjugation takes place between the small flagellated free-swimming cells and the large non-flagellate spherical cells. Each new cell formed by the fusion of one of the small and one of the large cells develops a cellulose wall and assumes a resting stage. After a time from each of these resting spores a new colony of sixteen or thirty-two cells is formed by direct, repeated division.

1\%. Volvox.-Another interesting colonial protozoan is Volvox. The large spherical colonies of Volvox globator 
(Fig. 16) are composed of several thousand cclls, arranged in a single peripheral layer about the hollow center of the ball. The cells are ovoid, and cach is provided with two long flagella which project out into the water. The lashing of the thousands of the flagella give the balllike colony a rotary motion. The cells are held together by a jelly-like interccllular substance and are connected with each other by fine protoplasmic threads which extend from the body protoplasm of one ccll to the cells surrounding it. When the colony is full grown and ready to reproduce itself certain cells of the colony undergo great changes. Somc of them increase in size enormously, having reserve food material stored in them, and thcy may be called the egg cells of the colony. Reproduction may now occur by simple division of one of thesc great cgg cells into many small cells, all held together in a common envelopc. These form a danghter colony which escapes from the
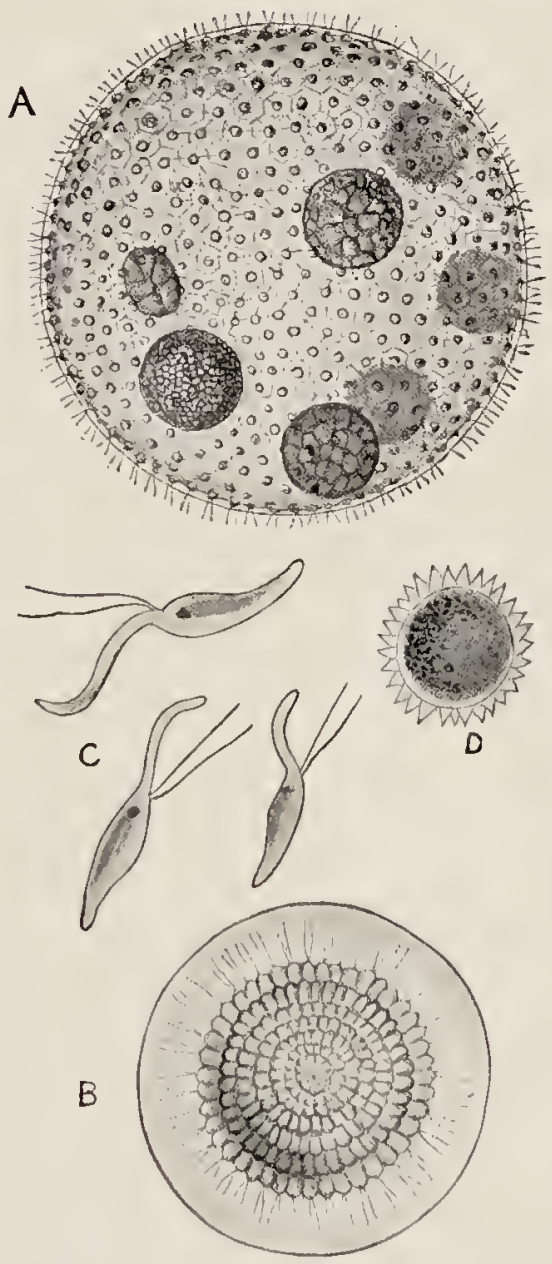

Fic. 16.-A, Tolvox minor, entire colony (from Natme). B, C, and 1), reproductive cells of Trolwex globutor. mother colony and by growth and further division comes to be a new full-sized colony. Or reproduction may occur in another, more complex, way. Certain cells of the colony 
divide into bundles of very small, slender cells, each of which is provided with flagella. The remaining cells of the colony (that is, those which have not swollen into egg cells or divided into many-sixty-four to one hundred and twenty-cight-minute, flagellatc cells) remain unchanged for a while and finally dic. They take absolutely no part in reproducing the colony. One of the minute free-swimming cells fuses with one of the enormous egg cells, the new cell thus formed being a resting spore. From this resting sporc a llew colony develops by repeated division.

18. Steps toward complexity.-Within the gromp of Tolvocince there are plainly several steps on the way from simplicity of structure to complexity of structure. Gonium, Pandorina, Eudorina, and Toliox form a series proceeding from the simplest animals toward the complex animals. In Gonium the cells composing the colony are all alike in structurc, and each one is capable of performing all the processes or functions of life. In Pandorina and Eulorina the cells are at first alike, but there is, as the time for reproduction approaches, a differcntiation of structure; the cells of the colony, all of which take part in the process of reproduction, conc to be in certain generations of two kinds-an inactive large kind which may be called the egg cells, and a small, active, free-swimming kind which seeks out and conjugates with, or, we may say, fertilizes the $\mathrm{cgg}$ cells. In Toterer there is a new diflerentiation. Only certain particular and relatively few cclls take part in reproducing the colony; most of the cells have given up the power or function of reproduction. These cells, when the time of multiplication comes, simply support the special reproductive cells. They continue to waft the grcat colony through the water by lashing their flagella; they continue to take in food from the outside. The reproductive cells devote themselves wholly to the business of producing new colonies, of perpetuating the species. And this matter of reproduction is less simple than in the other Volvocine. 
At least there is much more differenee between the two kinds of reproduetive eells. The egg eells are comparatively enormous, and they are stored with a mass of food material. The fertilizing eells are very small, but very aetive and very different from the egg eells. We have in Tolvox the beginnings of a distinet division of labor and an aceompanying differentiation of structure. Certain cells of the colony do eertain things, and are modified in strueture to fit them speeially for their partieular duties. The steps from the simplest strueture toward a complex strueture are plainly visible.

19. Individual or colony.-Is the Gonium eolony, the Pantorina eolony, or the Tolvox eolony a group of several or many distinet organisms, or is it to be eonsidered as a single organism? Nith Gonium, which we may eall the simplest of these eolonial organisms, the eolony is eomposed of a few wholly similar cells or one-celled animals, each fully eapable of performing all the life processes, each wholly competent to lead an independent life. In fact, each does, for part of its life, live independently, as we have already deseribed. In the ease of Pandorina and Eudorina, while all the cells are for most of the lifetime of the eolony alike and each is eapable of living independently, at the time of reproduction the cells become of two kinds. A difference of strueture is apparent, and for the perpetuation of the speeies the co-operation of these different kinds of cells is nccessary. 'That is, it is impossible for a single one of the members of the colony to reproduce the eolony, cxeept for a limited number of generations. With Folvox this giving up of independenee on the part of the individual members of the eolony is more marked. There is a real interdependence among the thousands of cells of the colony. The function of reproduction rests with a few partieular eells, and for the perpetuation of the speeies there is demanded a eo-operation of two distinet kinds of reproduetive eells. The great majority of the cells take no part in reproduc- 
tion. They can perform all the other life proeesses; they move the colony by lashing the water with their flagella; they take in food and assimilate it; they ean focl. All the cells of the great colony, too, are intimately connected by means of protoplasmic threads. The protoplasm of one cell can mingle with that of another cell; food can go from cell to eell. The question whether the Tolvox colony is a group of distinct organisms or is a single organism made up of cells among which there is a simple but obvious differenee in structure and function; in other words, whether Tolvox is a colony of one-eelled animals, of Protozoa, or is a multicellular animal, one of the Metazoa (for so all the many-eclled animals are ealled), is a difficult one to decide. Most zoülogists class the Volrocina with the Protozoa-that is, they incline to eonsider Gonimm, Pandorina, Tolvox, and the other Tolrocinæ as groups or eolonies of one-celled animals.

20. Sponges. - If the Totrocince be considered to belong to the Protozoa, the sponges are the simplest of all the many-eelled animals. Sponges are not free-swinnming animals, except for a short time in their young stage, but are fixed, like plants. They live attached to some solid substance on the sea bottom. They resemble plants, too, in the way in whiel the body is modified during growth by the environment. If the rock to which the young sponge is attached is rough and meven, the borly of the sponge will grow so as to fit the nuevenness; if the rock surfice is smooth, the body of the sponge will be more regular. 'Thus a sponge may be said to have no fixed shape of body: individuals of the sume species of sponge differ much in form. The typical form of the sponges is that of a short cylinder or vase attaehed by one end and with the mpper free end open (Fig. 17). Many individuals of one kind nsually live together in a close group or colony, and they may be so attached to oach other as to appear like a branching plant. 'Ihis branehing may be very diffuse, and the branehes 
may become so interwoven with each other as to form a very complex group. A sponge is composed of many eells arranged in three layers - that is, the body of a sponge is a eylinder elosed at one end whose wall is eomposed of three layers of eells. The outer layer of eells is ealled the ectoderm, and the eells eomposing it are flat and are all elosely attaehed to eaeh other. The inner layer is ealled the endoderm, and its eells are thieker than those of the eetoderm; they are also elosely attaehed to eaeh other. Sometimes they are provided with flagella like the flagellate Protozoa. The flagella are, however, not for the purpose of loeomotion, but for creating currents in the water, whieh bathes the interior of the open eylindrical body. The middle layer, ealled the mesoderm, is composed of numerous separate eells lying in a jelly-like matrix. From these mesoderm eells fine needles or spienles of lime or siliea often projeet out through the ectoderm. 'These minute sponge spienles are of a great variety of slapes, and they form a sort of skeleton for the support of the soft body mass. All over the outer surface of the body are seattered fine openings or pores, which

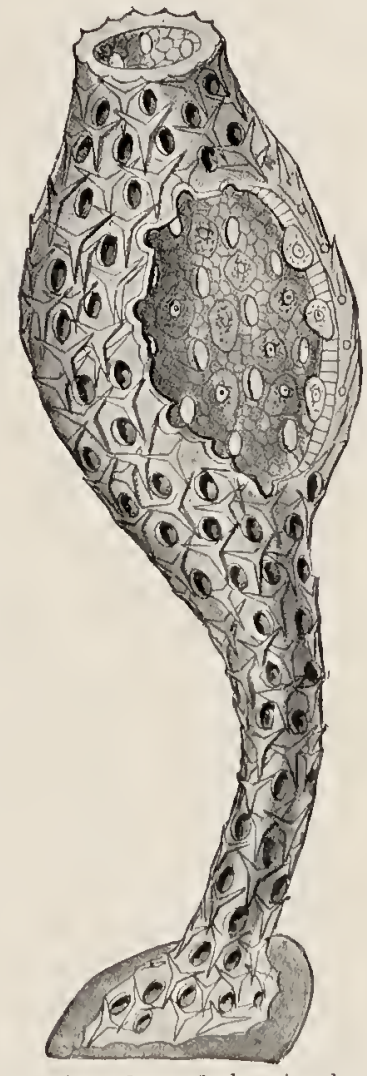

Fic. 17.-One of the simplest sponges, Calcolynthus primigenius (after IIAFCTELL). A part of the outer wall is cut away to show the inside. lead through the walls of the body into the imner eavity. This eavity is of course also eonneeted with the ontside by the large opening at the free or apieal end of the body.

There is hardly any differentiation of parts among the 
sponges. As in the Protozoa, there are no special organs for the performance of special functions. The sponge feeds by creating, with its flagella, water currents which

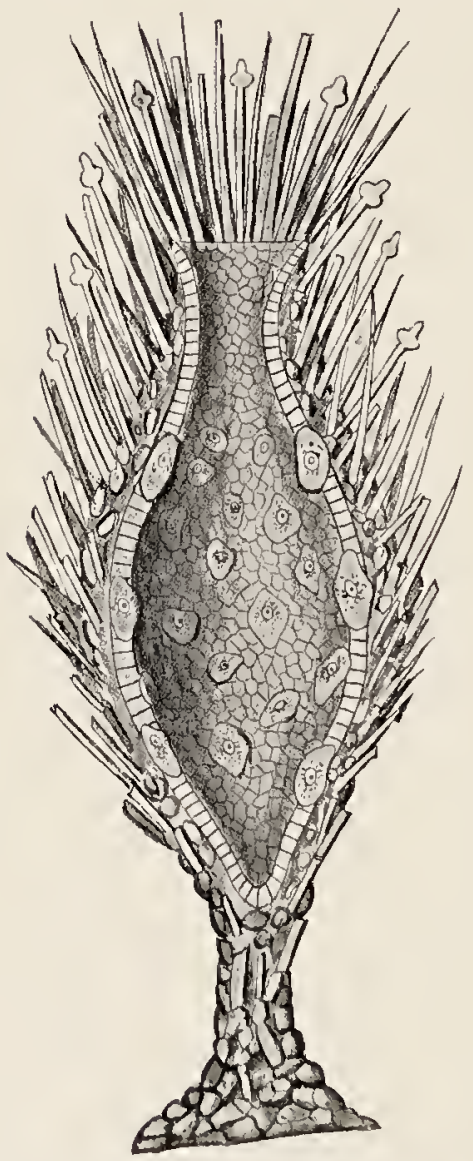

Fit. 1N.-One of the simple spouges, Prophysema mimordiale (nfter llAECKEL). The body is represented as cut in two longitudinally. The large cells of the inner layer are the egg cells. flow in through the many fine pores of the body and out from the inner body cavity through the large opening at the free end of the body. These currents of water bear fine particles of organic matter which are taken up by the cells lining the pores and body carity, and assimilated. There are no special organs of digestion. Each cell takes up food and digests it. The water currents also bring air to these same cells, and thns the sponge breathes. Although the sponge as a whole can not move, does not possess the power of locomotion, yet the protoplasm of the cells has the power of contracting, just as with the Protozoa, and the pores can be opened or closed by this cellular morcment. Practically, thus, the only movements the sponge can make are the morements made by the individual cells.

Reproduction is accomplished by a process of division, or by a process of conjugation and subsequent division. In its simplest way multiplication takes place by a group of cells separating from the body of the parent sponge, 
becoming inclosed in a eommon eapsular envelope, and by repeated division and consequent increase in number of cells becoming a new sponge. This is reproduetion by "budding." The "buds," or small gromps of eells whieh separate from the parent sponge, are called gemmules. Reproduction in the more complex way occurs as follows: Some of the free anmoboid eells of the mesoderm (the middle one of the three layers of the body wall) become enlarged and spherical in form. These arc the egg cells. Other mesodermie eells divide into many small cells, whieh are oval with a long, tapering, tail-like projeetion. These cells are active, being able to swim by the lashing of the tapering tail. These are the fertilizing eells. The two kinds of reproductive eells may be formed in one sponge; if so, they are formed at different times. Or one sponge may produee only egg eells, another only fertilizing or, as thcy are ealled, sperm eells. Conjugation takes plaee between a sperm cell and an egg eell. That is, one of the small active sperm cells finds one of the large, spherieal, inaetive cells and penetrates into the protoplasm of its body. The two cells fuse and form a single eell, which may be called the fertilized or impregnated egg. This fertilizcd egg, remaining in the body mass of the parent sponge, divides repeatedly, the new cells formed by this division remaining together. The young or embryo sponge finally cscapes from the body of the parent sponge, and lives for a short time as an active frec-swimming animal. Its body consists of an oval mass of eclls, of which those on one side are provided with cilia or swimming hairs. The cells of the body continue to divide and to grow, and the body shape gradually changes. The young sponge finally bccomes attached to some roek, the body assumes the typical eylindrieal shape, an aperture appoars at the free end, and small perforations appear on the surface. The sponge becomes full grown.

It is unfortunate that most of us do not live on the 
seashore, and henee can not observe the structure and life history of the living oeean sponges. There are, however, among the thousand and more kinds of sponges a few kinds which live in fresh water, and these are so widely spread over the earth that examples of them ean be found in almost any region. They belong to the genus Spongilla, and thirty or more species or kinds of Spongilla are known. In standing or slowly flowing water, Spongilla grows erect and branching, like a shrub or miniature tree; in swift water it grows low and spreading, forming a sort of mat over the surface to which it is attached. Reproduction takes place very actively by the process of budding. The budded-off gemmules are spherical in shape, and the cells of each gemmule are inclosed in an envelope composed of siliceous spicules of peculiar shape. These gemmules are formed in the body substance of the parent sponge toward the end of the year, and are set free by the decaying of that part of the body of the parent sponge in which they lie. They sink to the bottom of the pond or brook, and lie there dormant until the following spring. Then they develop rapidly by repeated division of the cells and growth.

It is impossible here to tell anything of the many and interesting kinds of sponges which inhabit the ocein. The "sponge" of the bathroom is simply the skeleton of a large sponge or group of sponges. The skeleton here is not composed of lime or silica, but of a tough, horny substance, which is secreted by eells of the mesodermal layer of the body wall of the sponge. This substance is called spongin, and is a substance allied to silk in its chemieal composition. All the commercial sponges, the spongin skeletons, belong to one genus-Sponyia. These sponges grow especially abmulantly in the Mediterranean and Red Seas, and in the Atlantic Ocean off the Florida reefs, and on the shores of the Bahama Islands. The sponges are pulled up by divers, or by means of looks or dredges. The 
living matter soon dies and decays, leaving the horny skeleton, which when cleaned and trimmed is ready for use.

The most beautiful sponges are those with silieeous skeletons. The fine needles or threads of glass, arranged often in delicate and intrieate pattern, make these sponges objeets of real beauty.

21. Polyps, corals, and jelly-fishes-The general or typieal plan of body structure of those animals which come next in degree of complexity to the sponges ean be best understood by imagining the typical cylindrieal body of a sponge modified in the following way: The middle one of the three layers of the body wall not to be eomposed of eells in a gelatinous mass, but to be simply a thin noneellular membrane; the body wall to be piereed by no fine openings or pores, so that the interior cavity of the body is conneeted with the outside only by the single large opening at the free end, and this opening to be surrounded by a eirelet of arm-like processes or tentaeles, continuations of the body wall and similarly composed. Such a body structure is the general or fundamental one for all polyps, corals, sea-anemones, and jelly-fishes. The variety in shape and the superficial modifications of this type-plan are many and striking; but, after all, the typeplan is recognizable throughout the whole of this great group of animals. Perhaps the simplest representative of the group is a tiny polyp which grows abundantly in the fresh-water streams and pools, and can be readily obtaincd for observation. It is called IIydra.

22. Hydra.-The body of Hydra (Fig. 19), which is very small and appears to the unaided eye as a tiny white or greenish gelatinous particlc attaehed to some submerged stone or bit of wood or aquatie plant, is a simple eylinder attached by onc end to the stone or wecd. The other frce end is eontracted so as to be conical, and it is narrowly open. Around the opening are six or eight small waving 
tcntacles. The wall of the cylinder is composed of an outer and an inner layer of cells and a thin non-cellular membranous layer betwecn them. The tentacles are hollow and are simple expansions of the body wall. The cells of the outer layer, or ectoderm, are not all alike. Some are smaller than the others and appear to be crowded in

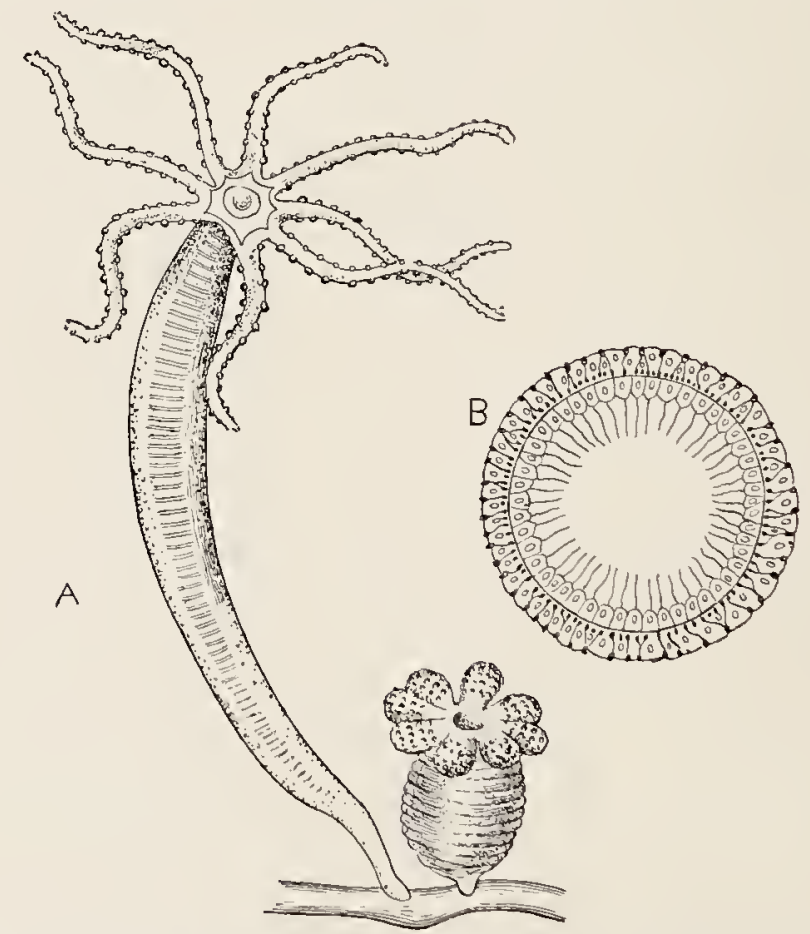

Fig. 19.-The fresli-water polyp, IIylla mlgaris. A, in expanded condition, and in contracted condition; 13 , cross section of body, showing the two layers of cells which make up the body wall.

betwecn the bases or inner cnds of the larger oncs. 'The imner cnds of the large cells are extended as narrow-pointed prolongations directed at right angles with the rest of the ccll. These processes are very contractile and are called muscle processes. Each onc is simply a continuation of the protoplasm of the cell body, which is especially contractile. Some of the smallcr ectoderm cells are very 
irregular in shape and possess specially large nuclei. These cells are more irritable or sensitive than the others and are called nerve cells. The ectoderm cells of the base or foot of the IIydra are peculiarly granular, and secrete a sticky substance by which the Hydra holds fast to the stone or weed on which it is found. These cclls are called gland cells. Imbedded in many of the larger ectoderm cells, especially those of the tentacles, are small oval sacs, in each of which lies folded or coilcd a fine long thread. When the tentacles touch one of the small animals which serve Hydra as food, these fine threads shoot out from their sacs and so poison or sting the prey that it is paralyzed. The tentacles then contract and bend inward, forcing the captured animal into the mouth opcning in the center of the circle of tentacles. Through the mouth opening the prey cnters the body cavity of Iydra and is digested by the cells lining this cavity. These cells belonging to the inner layer of the body wall or endoderm are mostly large, and each contains one or more contractile vacuoles. From the free cnds-the ends which are next to the body cavity-of these cells project pseudopods or finc flagella. These projcctions arc constantly changing: now two or three short, blunt pseudopods are projccting into the body cavity; now they are withdrawn, and a few finc, long flagella are projected. In addition to these cells there are in the endoderm, espccially abundant ncar the mouth opening and wholly lacking in the tentacles and at the base of the body, many long, narrow, granular cells. They are gland cells which secrete a digcstive fluid. 'The food captured by the tentacles and taken in through the mouth opening disintegrates in the body cavity, or digestive cavity, as it may be called. The digestive fluid secreted by the gland cells of the endoderm acts upon it, so that it beconies broken into small parts. These particles are probably seized by the pseudopods of the other endoderm cells and are taken into the body protoplasm 
of these cells. The ectoderm cells do not take food dircetly, but receive nourishment only through the endoderm cells.

Hydra is not permanently attached. It holds firmly to the submerged stone or weed by means of the sticky secretion from the ectodermal gland cells of its base, but it can loosen itself, and by a slow creeping or gliding move along the surface of the stone to another spot. Even when attached, the form of the body changes; it extends itself longitudinally, or it contracts into a compact globular mass. The tentacles move about in the water, and are continually contracting or extending.

Like Volvox and the sponges, those other slightly complex animals we have already considered, Hydra has two methods of multiplication. In the simpler way, there appears on the outer surface of the body a little bud which is composed, at first, of ectoderm cells alone; but soon it is cvident that it is a budding, or outpushing, of the whole body wall, ectoderm, endoderm, and middle membrane. In a few hours the bud has six or eight tiny, blunt tentacles, a mouth opening appears at the free end, and the little Hydra breaks off from the parent body and leads in independent existence. In the nore complex way, two kinds of special reproductive cells are produeed by each individual, viz., large, inactive, spherieal egg cells, and small, active sperm cells, each with an oval part or head (consisting of the nuclens) and a slender, tapering tail-like part (consisting of the cytoplasm). The egg cell lies inclosed in a layer of thin, surromnding cells, which compose a capsule for it. When the egg cell is ready for fertilization this capsule breaks, and one of the active sperm cells finds its way to and fuses with the egg cell. The fertilized egg cell now divides into several cells, which remain together. The onter ones form a hard capsule, and thus protected the cmbryo falls to the bottom, and after lying dormant for awhile devclops into a Hydra. 
23. Differentiation of the body cells.-In Hydra we have the beginnings of complexity of structurc carricd a step further than in the sponges. 'The division of labor among the cells composing the body is more pronounced, and the structural modification of the different cells to enable them better to perform their spccial duties is obvions. Some of the cells of the body specially devote themsclves to foodtaking; some specially to the digestion of the food; some are specially contractile, and on them the movements of the body depend, while others are spccially irritable or scnsitive, and on them the body depends for knowledge of the contact of prey or enemies. In the lasso cells-those with the stinging threads-there is a very wide departure from the simple primitive type of cells. There is in Hydra a manifest differentiation of the cclls into varions kinds of cells. The beginnings of distinct tissues and organs are foreshadowed.

'The indiriduals of Hydre live, usually, distinct from each other. 'Therc is no trec-like colony, as with the sponges. But most of the other polyps do live in this colonial manner. The new polyps which develop as buds from the boly of the parent do not separate from the parent, but remain attached by their bases. 'They, in turn, produce new polyps which remain attached, so that in time a branching, tree-like colony is formed.

24. Medusæ or jelly-fishes.-Most of the other polyps differ from IIydra also in producing, in addition to ordinary polyp buds, buds which devclop into bell-shitped structures called medusce (Fig. 20). Thesc medusie consist of a soft gelatinous bell- or umbrella-shaped body, with a short clapper or stem which has an opening at its frec end. From the edge of the bell or umbrella four pairs of tentacles arise. The mcdusæ usually separate from the parent polyp and live an independent, frce-swimming lifc. 'These are the beautiful animals commonly known as jelly-fishes. The medusæ or jelly-fishes produce special reproductive 
cells, a single medusa producing only onc kind of such cells - that is, producing cither egg cells alone or sperm cclls alone. The active sperm cells produced by onc medusa find their way to an egg cell producing medusa, and fuse with or fertilize these egg cells. The

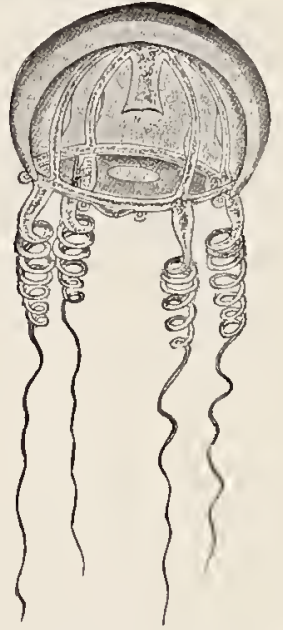

Fig. 20.- A medusa, Eucope. -After IrAECKEL. fertilized egg develops into a small, oval, free-swimming embryo called a planulu, which finally attaches itself to a stone or bit of wood or seaweed, and grows to be a simple cylindrical polyp attached at its base and with mouth and tentacles at its free end. This polyp gives rise by budding to new polyps, which remain attached to it, and gradually a new tree-like colony is formed. From this polyp or this colony new medusa bud off, swim away, and finally produce new polyps. Thus there is in the life of the polyps what is called an alternation of generations. There are two kinds of individuals which evilently belong to the same species of animal, or, put in another way, one kind of animal has two distinet forms. This appearance of one kind of animal in two forms is called dimorphism. Te shall see later that one kind of animal may appear in more than two forms; such a condition is called polymorphism. In alternation of gencrations we have the polyp animal appearing in one generation as a fixed cylindrical polyp, while in the next generation it is a free-swimming, umbrella-shaped medusa or jelly-fish.

The polyps which are dimorphic-that is, have a polyp form of individual and a medusa form of individual-show more differentiation in structure than the simple $I y d r a$. This further differentiation is especially apparent in the medusie or jelly-fishes. IIcre the nerve colls are aggregated in little groups arranged along the edge of the umbrella 
to form distinct sense organs. The muscle processes are better developed, and the digestive cavity is differentiated into central and peripheral portions. In these dimorphic polyps the fixed polyp individnals reprodnce by the simple way of budding, while the medusa individuals reprodnce by producing special reproductive cells of two kinds, which must fuse to form a cell capable of developing into a new polyp.

25. Corals.-There are many kinds of polyps and jellyfishes, and they prosent a great variety of shape and size and general appearance. Many polyps cxist only in the true polyp form, never producing medusæ. Others have

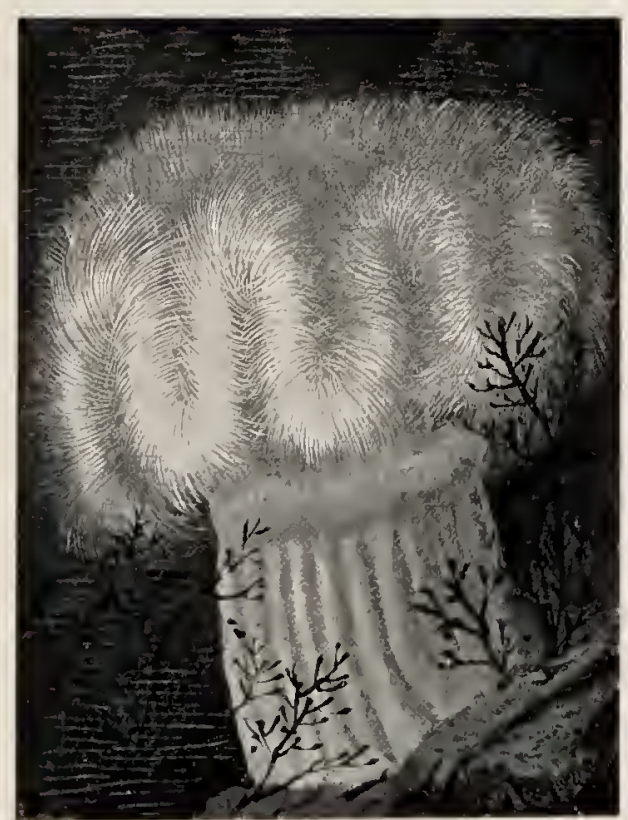

FIt. 21.-A polyp, or sea-anemone (Metrilium dianthus).

only the medusa form. Some live in colonics, and others are always solitary. The animals we know as corals are polyps which live in enormous colonies, and which exist only in the true polyp form, not producing medusæ. They 


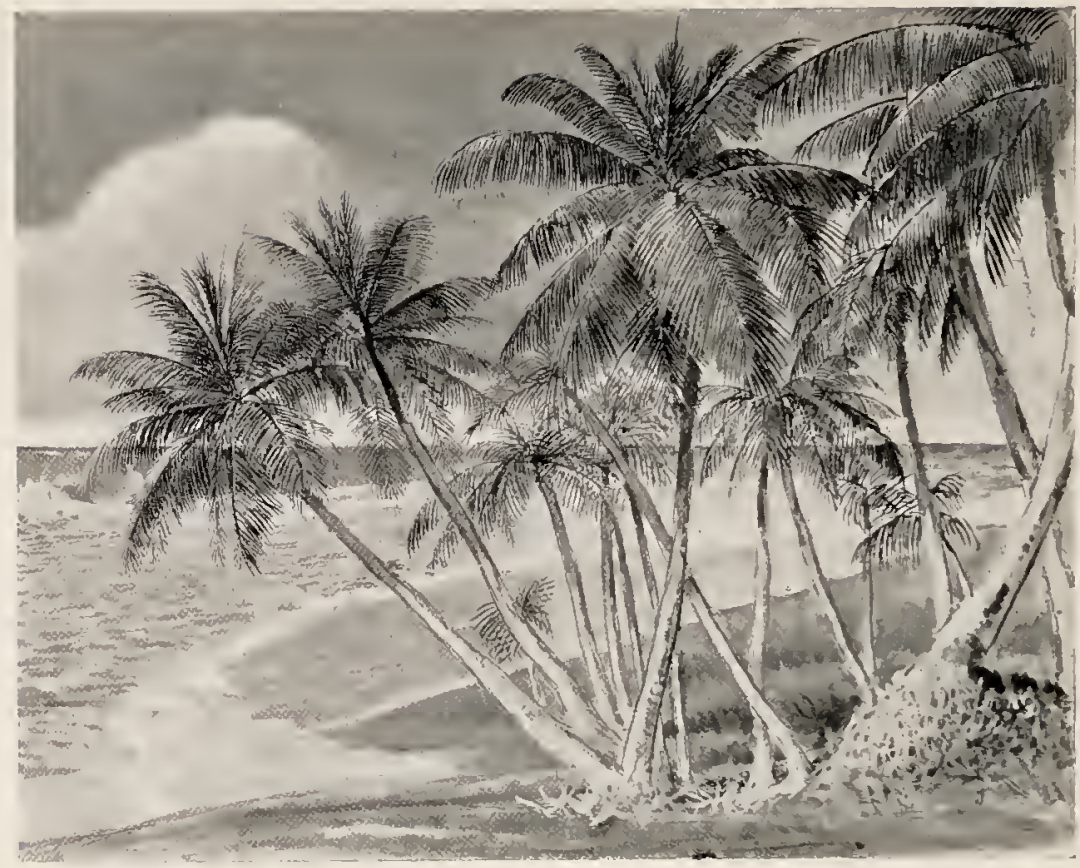

FIt, 22.-Coral island (atoll), looking seaward, showing line of breakers.

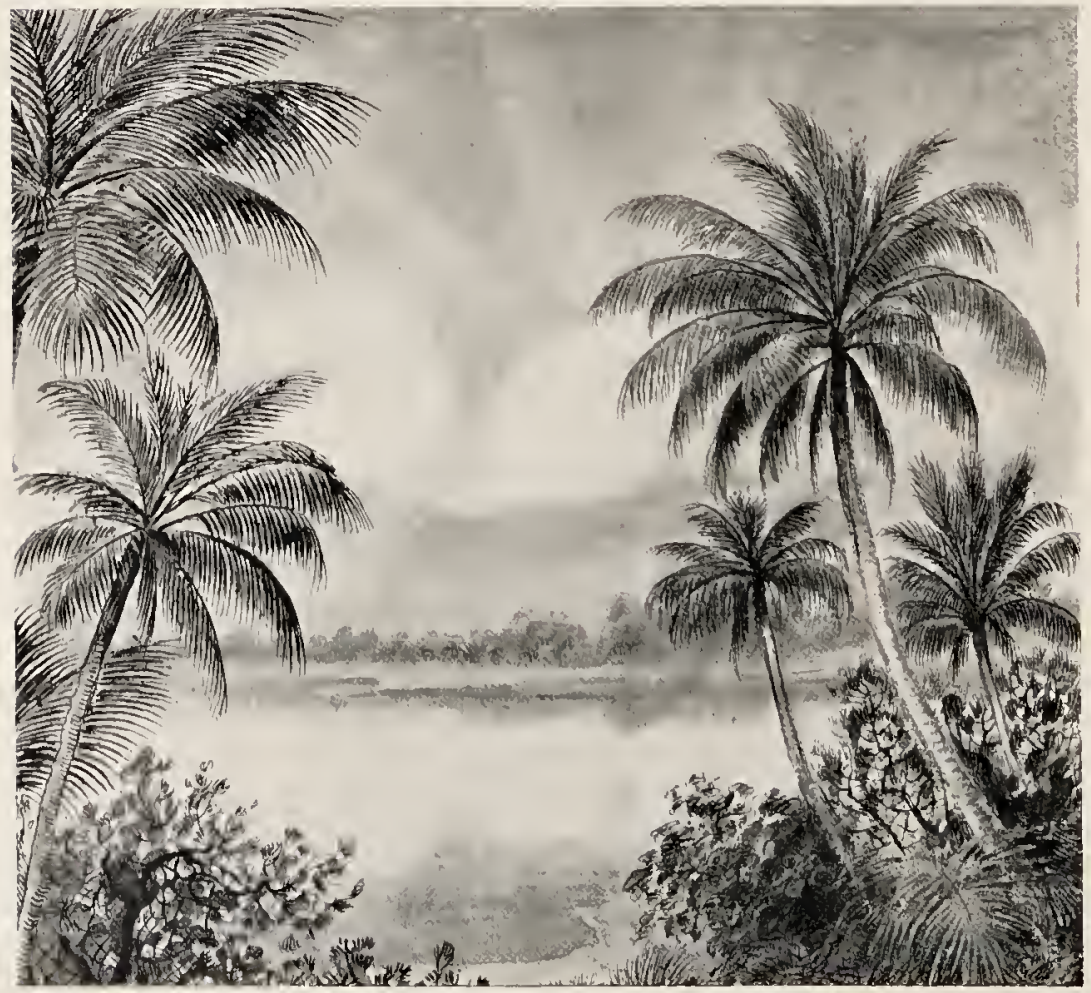

Fit. 23.-Coral island, view across lagoon. 
form a firm skeleton of lime (calcium carbonate), and after their death these skeletons persist, and because of their abundance and close massing form great reefs or banks and islands. Coral islands occur only in the warmer oceans. In the Atlantic they are found along the coasts of southern Florida, Brazil, and the West Indies; in the Pacific and Indian Oceans there are great coral reefs on the coast of Australia, Madagascar, and elsewhere, and certain large

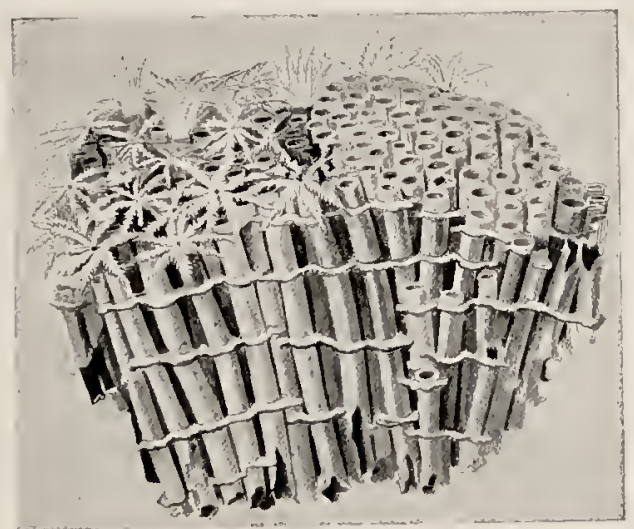

Fig. 24.-Organ-pipe coral.

groups of inhabited islands like the Fiji, Society, and Friendly Islands are composed exclusively of coral islands. More than two thousand kinds of living corals are known, and their skeletons offer much variety in structure and appearance. Brain coral, organ-pipe coral (Eig. 24), the well-known red coral from Italy and Sicily, used as jewelry, and the sea pens and sea fans are among the better known and more beautiful kinds of coral skeletons.

26. Colonial jelly-fishes. - Whilc many of the medusæ or jelly-fishes are another form of individual of a truc fixed polyp, many of the larger and more beautiful jelly-fishes do not exist in any other form. Some of these larger jellyfishes are several feet in diameter, and when cast up on the beach form a great shapelcss mass of soft, jclly-like sub- 
stanee. The bodies of all jelly-fishes are soft and gelatinous, the body substanee eontaining hardly one per eent of solid matter. It is mostly water. Many jelly-fishes are beautifully and strikingly eolored, and as they swim slowly about near the surfaee of the oeean, lazily opening and shutting their irideseent, umbrella-like bodies, they are among the most beantiful of marine organisms. When one of the jelly-fishes is taken from the water, however, it quiekly loses its brilliant eolors, and dries away to a shapeless, shriveling, stieky mass.

Some of the most beautiful of the jelly-fishes belong to a group ealled the Siphonophora. These jelly-fishes are elongate and tube-like rather than umbrella- or bell-shaped, and they are polymorphie-that is, there are several different forms of individuals belonging to a single kind or speeies. The Siphonophora are all free-swimming, but nevertheless form small eolonies. In the Mediterranean Sea and in other southern oeean waters the smrfaee may be eovered for great areas by these brilliantly eolored jelly-fish eolonies, eaeh of whieh looks, as a eelebrated German naturalist has said, like a swimming flower cluster whose parts, flowers, stems, and leaves seem to be made of transparent erystal, but whieh possess the life and soul of an animal. An abundant spoeies of these Siphonophora (Fig. 25) is composed of a slender, flexible, floating, eentral stem several feet long, to which are attached thonsands of medusa and polyp individuals representing several different kinds of forms, each kind of individual being speeially modified or adapted to perform some one duty. The eentral stem is a greatly elongated polyp individual, whose upper end is dilated and filled with ail to form a float. 'This individual holds up the whole eolony. Grouped around this eentral stem just below the float are many bell-shaped bodies whieh alternately open and close, and by thus drawing in and expelling water from their eavities impel the whole eolony through the water. 'These bell-shrped struetures are attaehed me- 
dusa individuals, whose business it is to be the locomotive organs for the colony. These medusæ are without tentacles, and take no food and produce no young. They have given up the power of performing these other life processes, and devote themselves wholly to the business of locomotion. From the lower end of the eentral stem rises a host of structures, among whieh several distinet kinds are readily perceived. One kind is composed of a pcarshaped hollow body open at its frec end, and bearing a long tentacle which is furnished with numerous groups of stinging cells. These are the polyp individuals whose especial busincss it is to eapture and sting prey and to eat it. These individuals arc the food-getters for the colony. Seattered among these stinging, feeding polyps, are numerous smaller individuals with oval, elosed body, each bcaring a long, slender thread. These threads

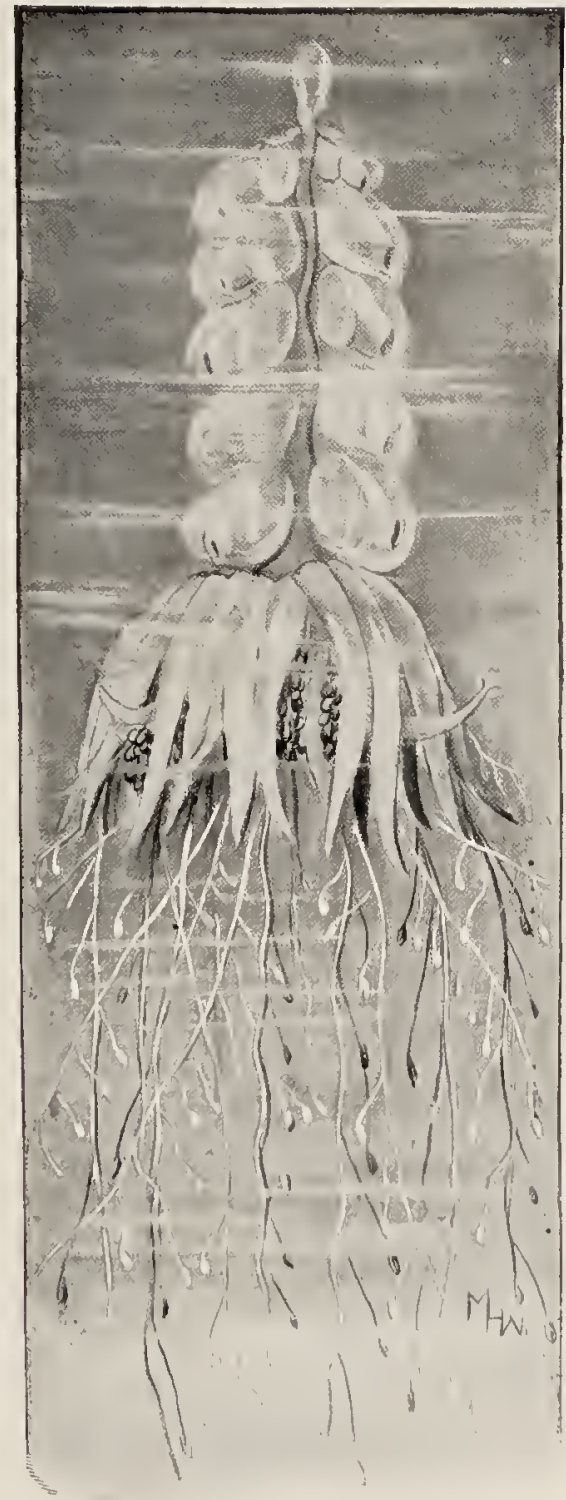

F16. 25.-A colonial jelly-fish, Physophora (after $11 \mathrm{AECKEL}$ ). At the top is the flont polyp, around its stem the swimming nedusa, and below are the feeding, feeling, protecting, and reproducing polyps and medusæ. 
are very sensitive, and the polyps bearing them have for spccial function that of feeling or being sensible of stimuli from without. They are the sense organs or sense individuals of the colony. Finally, there are two other kinds of structures or individuals which produce the special reproductive cells for the perpetuation of the species. These are the modified medusa individuals, and onc kind, larger than the other, produces the actire sperm cclls, while the other produces the inactive egg cells.

$2 \%$. Increase in the degree of complexity.-In the corals, sea-anemones, and jelly-fishes there is plainly much more of a division of labor among the various parts of an individnal and much more modification of these parts-that is, much more structural complexity than among the sponges and IIydra. And these, in thcir turn, are more complex than are the colonial Protozoa, the V'olvocinæ. There is a great difference in degree of complexity among the slightly complex animals. But the various groups of these animals which we have studicd can all be arranged roughly in a series beginning with the least complex anong them and ascending to the most complex. And in this series the gradual increase in complexity, and in the always accompanying division of labor anong the different parts, is bcautifully shown.

From an animal composed of many structurally similar cells, cach cell capable of performing all the life processes, we pass to an animal composed of cells of a few diffcrent kinds, of slight structural diversity. Each kind of ccll devotes itsclf especially to a certain few life processes or functions. Next we find an animal in which the cells of one kind are specially aggregated to form a single part of the body which is specially devoted to the performance of a single function. This diversity among the cells increases, this aggregation of similar cells to form special parts or organs increases, and the division of labor or assignment of special functions to special organs becomes 
more and more pronounced. Among the more complex polyps and jelly-fishes the contractile cells form distinct muscle fibers and muscles; the sensitive cells form distinct nerve cells and nerve fibers which are arranged in a primitive nervous system; the digestive cavity becomes complex and composed of different portions; the reproductive cells are formed by special organs, and the distinction between the egg cells and the sperm cells-that is, between the female reproductive elements and the male reproductive elements-becomes more pronounced.

We have followed this increase or development of structural and physiological complexity from simplest animals to fairly complex ones. The principle of this development of complexity is evident. It will not be profitable to attempt to follow in detail this development among the higher animals. The complex animals are complex because their life processes are performed by special parts of their body, which parts are specially modified so as to perform thesc processes well. The animals which are more complcx than those we have studied differ from these simply in the degree of complexity attained. In order to understand this better we shall not further considcr special groups of animals, but special processes or functions, and attcmpt to see how the modification and increasc in complexity of structure goes hand in hand with the incrcase of elaborateness or complexity in the performance of function. 


\section{CHAPTER III}

\section{THE MULTIPLICATION OF ANIMALS AND SEX}

28. All life from life.-On the performanee of the funetion of reproduction or multiplication depends the existenee or perpetuation of the speeies. Although an animal may take food and perform all the functions necessary to its own life, it does not fulfill the demands of successful existcnee unless it reproduces itself. Some individuals of every species must produce offspring or the speeies beeomes extinet. We have seen in our study of the simple animals that the function of reproduction is the first funetion to become differentiated in the ascent from simplest animals to eomplex animals. The first division of labor among the cells composing the bodies of the slightly complex animals and the first struetural differenees among the cells are connceted with the performanee of the funetion of reproduction or multiplieation.

We are so familiar with the fact that a new kitten comes into the world only through being born, as the offspring of parents of its kind, that we shall likely not appreciate at first the full signifieance of the statement that all life eomes from life; that all organisms are produeed by other organisms. Nor shall we at first appreeiate the importance of the statement. This is a generalization of modern times. It has always becn easy to see that cats and horses and chickens and the other animals we familiarly know give birth to young or new animals of their own kind; or, put conversely, that young or new cats and horses and chickens come into existence only as the off- 
spring of parents of their kind. And in these latter days of mieroseopes and meelianieal aids to observation it is even easy to see that the smaller animals, the mieroseopie organisms, come into existenee only as they are produeed by the division of other similar animals, which we may eall their parents. But in the days of the earlier naturalists the life of the mieroseopie organisms, and even that of many of the larger but unfamiliar animals, was shrouded in mystery. And what seem to us ridieulous beliefs were held regarding the origin of new individuals.

29. Spontaneous generation.-The aneients believed that many animals were spontaneously generated. The early naturalists thought that flies arose by spontaneous generation from the deeaying matter of dead animals; from a dead horse come myriads of maggots whieh ehange into flesh flies. Frogs and many inseets were tlought to be generated spontaneously from mud. Eels were thought to arise from the slime rubbed from the skin of fishes. Aristotle, the Greek philosopher, who was the greatest of the aneient naturalists, expresses these beliefs in his books. It was not until the middle of the seventeenth eenturyAristotle lived three luundred and fifty years before the birth of Christ-that these beliefs were attacked and began to be given up. In the begimning of the seventeentl eentury William Marvey, an English naturalist, deelared that every animal eomes from an egg, but he said that the egg might " proeeed from parents or arise spontaneously or" out of putrefaetion." In the middle of the same eentury Redi proved that the maggots in deeaying meat which prodnee the flesh flies develop from eggs laid on the meat by flies of the same kind. Other zoölogists of this time were aetive in investigating the origin of new individnals. And all their diseoveries tended to weaken the belief in the theory of spontaneous generation.

Finally, the adherents of this theory were foreed to restriet their belief in spontaneous generation to the case 
of a few kinds of animals, like parasites and the animalcules of stagmant water. It was maintained that parasites arose spontaneously from the matter of the living animal in which they lay. Many parasites have so complicated and extraordinary a life history that it was only after long and careful study that the truth regarding their origin was discovered. But in the case of every parasite whose life history is known the young are offspring of parents, of other individuals of their kind. No case of spontaneous generation among parasites is known. The same is true of the animalcules of stagnant watcr. If some water in which there are apparently no living organisms, howerer minute, be allowed to stand for a few days, it will come to bc swarming with mieroseopie plants and animals. Any organic liquid, as a broth or a rcgetable infusion exposed for a short time, bccomes foul through the presence of innumerable bacteria, infusoria, and other one-celled animals and plants, or rather through the clianges produced by their life processes. But it has been certainly proved that these organisms are not spontanconsly produced by the water or organic liquid. A few of them enter the water from the air, in which there are always greater or less numbers of spores of microscopic organisms. These spores (embryo organisms in the resting stage) germinate quickly when they fall into water or some organie liquid, and the rapid sucecssion of generations soon gives rise to the hosts of bacteria and Protozoa which infest all standing water. If all the active organisms and inactive spores in a glass of water are killed by boiling the water, "sterilizing" it, as it is ealled, and this sterilized water or organic liquid be put into a sterilized glass, and this glass be so well closed that germs or spores can not pass from the air without into the sterilized liquid, no living animals will ever appear in it. It is now known that flesh will not decay or liquids ferment execpt through the presenec of living animals or plants. 'T'o sum np, we may say that we know of no instance of the 
spontaneous generation of organisms, and that all the animals whose life history we know are produced from other" animals of the same kind. "Omne vivum ex vivo," All life from life.
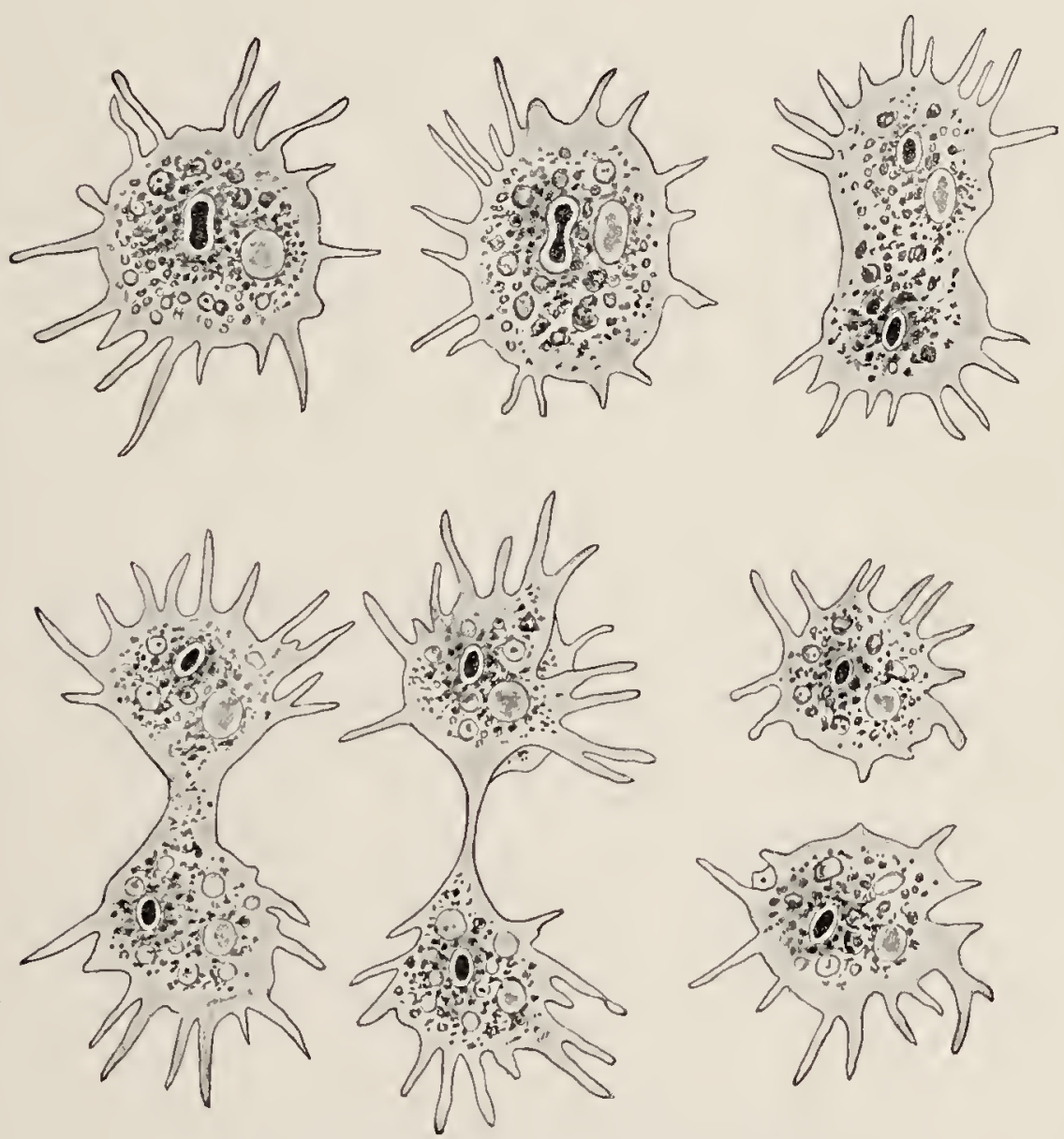

Fig. 26.-The multiplication of Amoba by simple fission.

30. The simplest method of multiplication.-In our study of the simplest and the slightly complex animals we became acquainted with the simplest methods of multiplication and with methods which are more complex. 'The method 
of simple fission or splitting-binary fission it is often ealled, beeause the division is always in two-by which the body of the parent beeomes divided into two equal parts-into halves-is the simplest method of multiplication. This is the only method of Amoba (Fig. 26) and of many other of the simplest animals. In this kind of reproduction it is hardly exaet to speak of parent and ehildren. The children, the new Amabce, are simply the parent eut into halves. The parent persists; it does not produee offspring and die. Its whole body eontinues to live. The new Amobce take in and assimilate food and add new matter to the original matter of the parent body; then each of them divides in two. The grandparent's body is now divided into four parts, one fourth of it forming one half of each of the bodies of the four grandehildren. The proeess of assimilation, growth, and subsequent division takes place again, and again, and again. Eaeh time there is given to the new Amaba an erer-lessening part of the actual body substanee of the original aneestor. Thus an Amoeba never dies a natural death, or, as has been said, "no Amoba ever lost an ancestor by death." It may be killed ontright, but in that ease it leaves no deseendants. If it is not killed before it prodnees new Imelice it nerer dies, although it eeases to exist as a single individual. The $A m a b a$ and other simple animals whieh multiply by direet binary fission maty be said to be immortal, and the "immortality of the Protozoa" is a phrase which you will be sure to meet if you begin to read the writings of the modern philosophieal zoölogists.

\section{Slightly complex methods of multiplication.-Most of} the Protozoi multiply or reproduee themselves in two ways-by simple fission and by eonjugation. Purumcecium, for example, reproduees itself for many generations by fission, but a generation finally appears in whieh a different method of reproduetion is followed. Two individuals eome together and eaeh exehanges with the other a part 
of its nucleus. Then the two individuals separate and each divides into two. The result of this conjugation is to give to the new Paramocia produced by the conjugating individuals a body which contains part of the body substance of two distinct individuals. The new Paramecia are not simply halves of a single parent; they are parts of two parents. If the two conjugating individuals differ at all-and they always do differ, because no two individual animals, altlongh belonging to the same species, are exactly alike-the new individual, made up of parts of each of them, will differ from both. We shall, as we study further, see that Nature seems intent on making every new individual differ slightly from the individual which produces it; and the method of multiplication or the production of new individuals which Nature has adopted to produce the result is the method which we have seen exhibited in its simplest form among the simplest animals-the method of having two individuals take part in the production of a new one. The further study of multiplication among animals is the study of the development and elaboration of this method.

32. Differentiation of the reproductive cells.-Among the colonial Protozoa the first differentiation of the cclls or members composing the colony is the differentiation into two kinds of reproductive cells. Reproduction by simple division, without preceding conjugation, can and does take place, to a certain extent, among all the colonial Protozoa. Indecd, this simple method of multiplication, or some modification of it, like budding, persists among many of the complex animals, as the sponges, the polyps, and even higher and more complex forms. But such a method of singleparent reproduction can not be used alone by a species for many generations, and those animals which possess the power of multiplication in this way always exhibit also the other more complex kind of multiplication, the method of double-parent reproduction. Conjugation takes place between different members of a single colony of one of the 
eolonial Protozoa, or between members of different eolonies of the same speeies. These eonjugating individuals in the simpler kinds of eolonies, like Gonium, are similar; in Pandorinu they appear to be slightly different, and in Eudorina and Volvox the eonjugating eells are very different from eaeh other (Figs. 15 and 16). One kind of eell, which is ealled the egg eell, is large, spherieal, and inaetive, while the other kind, the sperm eell, is small, with ovoid head and tapering tail, and free-swimming. In the simpler colonial Protozoa all the cells of the body take part in reproduction, but in Volvox only eertain eells perform this funetion, and the other eells of the body die. Or we may say that the body of Volvox dies after it has produced speeial reproductive eells which shall fulfill the function of multiplication.

Beginning with the more eomplex Volvocinæ, which we may eall either the most eomplex of the one-celled animals or the simplest of the many-celled animals, all the complex animals show this distinet differentiation between the reproduetive eells and the cells of the rest of the body. Of eourse, we find, as soon as we go mp at all far in the seale of the animal world, that there is a great deal of differentiation among the eells of the body: the eells which have to do with the assimilation of food are of one kind; those on whieh depend the motions of the body are of another kind; those whieh take oxygen and those whieh exerete waste matter are of other kinds. But the first of this eell differentiation, as we have already often repeated, is that shown by the reproduetive eells; and with the rery first of this differentiation between reproduetive eells and the other body eells appears a differentiation of the reproduetive eells into two kinds. These two kinds, anong all animals, are always essentially similar to the two kinds shown by Volvox and the simplest of the many-eelled animals-namely, large, inaetive, spherieal egg eells, and small, aetive, elongate or "tailed" sperml eells. 
33. Sex, or male and female.-In the slightly complex animals one individual produces both egg cells and sperm cells. But in the Siphonophora, or colonial jelly-fishes, studicd in the last chapter, certain nembers of the colony produce only sperm cells, and certain other members of the colony produce only egg cells. If the Siphonophora be considered an individual organism and not a colony composed of many individuals, then, of comrse, it is like the others of the slightly complex animals in this respect. But as soon as we rise higher in the scale of animal life, as soon as we study the more complex animals, we find that the egg cells and sperm cells are almost always produced by different individuals. Those individuals which produce egg cells are called female, and those which producc sperm cells are called male. There are two sexes. Malc and female are terms usually applied only to individuals, but it is evidently fair to call the egg cells the female reproductive cells, and the sperm cells the male reproductive cells. A single individual of the simpler kinds of animals produces both male and female cells. But such an individnal can not be said to be either male or female; it is sexlessthat is, sex is something which appears only after a certain degree of structural and physiological differentiation is reached. It is true that cren among many of the higher or complex animals certain species are not represcnted by male and femalc individuals, any individnal of the species being able to produce both male and female cells. But this is the exception.

34. The object of sex.-Among almost all the complex animals it is necessary that there bc a conjugation of male and female reproductive cells in order that a ncw individual may be produced. This necessity first appears, we remember, among very simple animals. This intermixing of body substance from two distinct individuals, and the development thercfrom of the new individual, is a phenomenon which takes place through the whole scalc of animal life. 
The object of this intermixing is the prodnction of rariation. Nature demands that the offspring shall differ slightly from its parents. By having the beginnings of its body, the single eell from which the whole body develops, composed of parts of two different individuals, this differenee, although slight and nearly imperceptible, is insured. Sex is a provision of Nature to insure variation.

35. Sex dimorphism.-As we have seen, almost every speeies of animal is represented by two kinds of individuals, males and fcmales. In the case of many animals, espe-

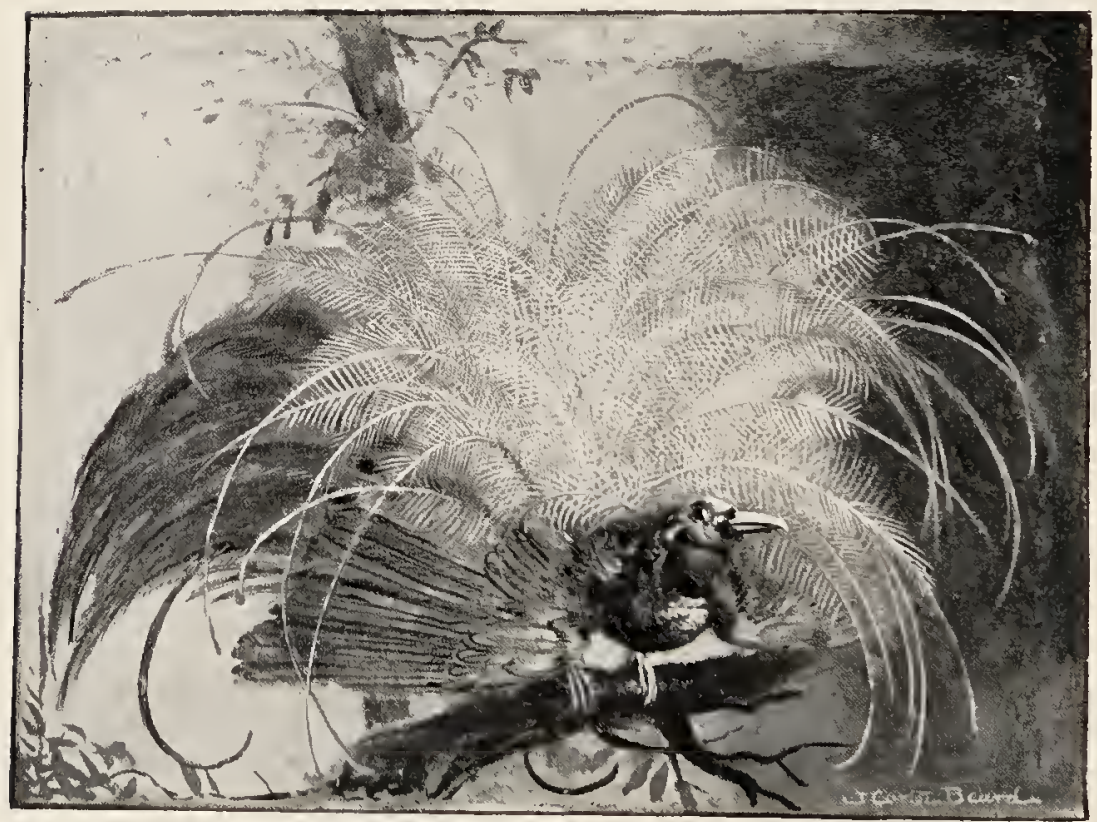

Fu, $2 z_{1}$ - Bird of parndise, male.

cially the simpler ones, these two kinds of individnals do not differ in appearance or in structure apart from the organs concerned with multiplication. But with many animals the scxes can be readily distinguished. The male and female individuals often show marked differences, espccially in external struetural characters. Te can read- 
ily tell the peacock, with its splendidly ornamental tail feathers, from the madorned peafowl, or the horned ram from the bleating ewe. There is here, plainly, a dimorphisn-the existence of two kinds of individuals belonging to a single specics. This dimorphism is due to scx, and the condition may be called sex dimorphism. Among some animals this sex dimorphism, or difference betwcen the sexes, is carried to extraordinary extremes. This is especially true among polygamous animals, or those in which the males mate with many females, and are forced to fight for their possession. The male bird of paradise, with its gorgeous display of brilliantly colored and fantastically shaped feathers (Fig. 2\%), seems a wholly different kind of bird from the modest brown female. The male golden and silver phcasants, and allied spccies with their elaborate plumage, are very unlike the dull-colored females. The great, rough, warlike male fur seal, roaring like a lion, is three times as large as the dainty, soft-furred femalc, which bleats like a shecp.

Among some of the lower animals the differences bctween male and female are even greater. The males of the common cankerworm moth (Fig. 28) have four wings;
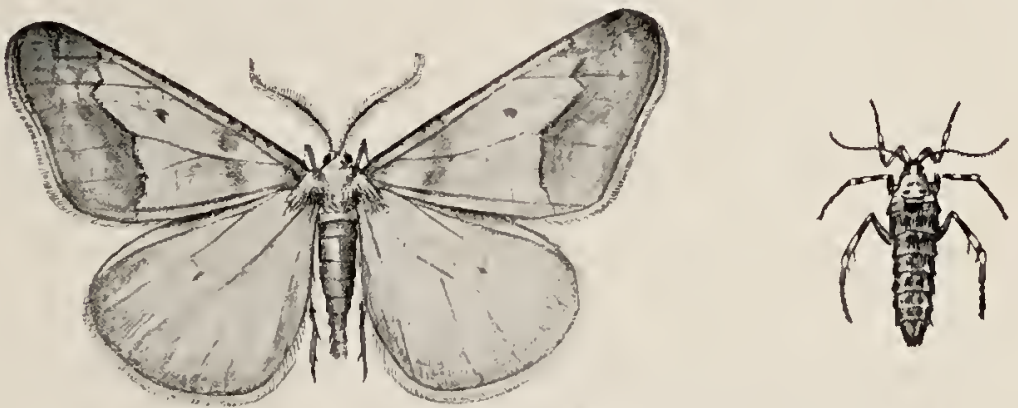

FIG. 28.-Cankerworm moth; the winged male and wingless female.

the femalcs are wingless, and several other insect specics show this same difference. Among ccrtain species of white ants the females grow to be five or six inches long, while the males do not exceed half an inch in length. In the 
ease of some of the parasitic worms which live in the bodies of other animals, the malc has an extraordinarily degraded, simple body, much smaller than that of the female and differing greatly from that of the female in structure.

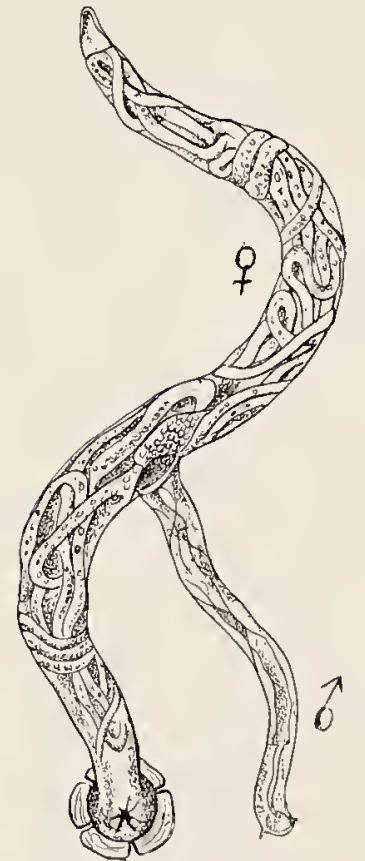

Fig. 29.-The parasitic worm

(Syngamus trucheatis), which causes the "gapes" in fowls. The male is attuched to the female, and lives as a parasite on her.

In some eases even-as, for example, the worm which causes "gapes" in chickens - the male lives parasitieally on the female, being attaehed to the body of the female for its whole lifetime, and drawing its nourishment from her blood (Fig. 29).

A condition known as parthenogenesis is found among certain of the complcx animals. Although the speeies is represented by individuals of both sexes, the female ean produce young from eggs which have not been fertilized. For example, the qucen bee lays both fertilized and unfertilized eggs. From the fertilized eggs hatch the workcrs, whieh are rudimentary females, and other queens, which are fullydeveloped females; from the unfertilized eggs hatch only males-the drones. Many generations of plant lice are prodnced eaeh year parthenogenctically - that is, by unfertilized females. But there is at least one generation each year produced in the normal way from fertilized eggs.

Some of the eomplex animals are hermaphroditic-that is, a single individual produces both egg cells and sperm cells. The tapeworm and many allied worms show this condition. 'This is the normal condition for the simplest animals, as we lave already learned, but it is an cxceptional condition among the eomplex animals. 
36. The number of young.-There is great variation in the number of young produeed by different speeies of animals. Among the animals we know familiarly, as the mammals, whieh give birth to young alive, and the birds, which lay eggs, it is the general rule that but few young are produced at a time, and the young are born or eggs are laid only onee or perhaps a few times in a year. 'The robin lays five or six eggs once a year; a cow may produee a ealf each year. Rabbits and pigeons are more prolifie, each having several broods a year. But when we observe the multiplieation of some of the animals whose habits are not so familiar to us, we find that the production of so few young is the exeeptional and not the usual habit. A lobster lays ten thousand eggs at a time; a queen bee lays about five million eggs in her life of four or five years. A female white ant, which after it is full grown does nothing but lie in a cell and lay eggs, produees eighty thousand eggs a day steadily for several months. A large codfish was found on dissection to contain about eight million eggs.

If we search for some reason for this great differenee in fertility among different animals, we may find a promising clew by attending to the duration of life of animals, and to the amount of care for the young exereised by the parents. We find it to be the general rule that animals whieh live many years, and whieh take care of their young, produce but few young; while animals which live but a short time, and which do not eare for their young, are very prolific. The codfish produces its millions of eggs; thousands are eaten by sculpins and other predatory fishes before they are hatched, and other thousands of the defenseless young fish are eaten long before attaining maturity. Of the great number produced by the parent, a few only reach maturity and produce new young. But the eggs of the robin are hatched and proteeted, and the helpless fledglings are fed and cared for until able to cope with their natural 
enemies. In the next year another brood is carefully reared, and so on for the few years of the robin's life.

Under normal conditions in any given locality the number of individuals of a certain species of animal remains about the same. The fish which produces tens of thousands of eggs and the bird which reproduces half a dozen eggs a year maintain equally well their numbers. In one case a few survive of many born; in the other many (relatively) survive of the few born; in both cases the species is effectively maintained. In general, no agency for the perpetuation of the species is so effective as that of care for the young. 


\section{CHAPTER IV \\ FUNCTION AND STRUCTURE}

3\%. Organs and functions.-An animal does eertain things whieh are neeessary to life. It eats and digests food, it breathes in air and takes oxygen from it and breathes out earbonie-aeid gas; it feels and has other sensations; it produees offspring, thus reprodueing itself. These things are done by the simplest animals as well as by the eomplex animals. But while with the simplest animals the whole body (whieh is but a single eell) takes part in doing eaeh of these things, among the eomplex animals only a part of the body is eoneerned with any one of these things. Only a part of the body has to do with the taking in of oxygen. Another part has to do with the digestion of food, and another with the business of loeomotion. These parts of the body, as we know, differ from each other, and they differ beeause they have different things to do. These different parts are ealled organs of the body, and the things they do are ealled their functions. The nostrils, traeher, and lungs are the organs whieh have for funetion the proeess of respiration. The legs of a eat are the organs which perform for it the funetion of loeomotion. The strueture of one of the higher animals is eomplex beeanse the body is made up of many distinet organs having distinet funetions. The things done by one of the eomplex animals are many; around eaeh of the prineipal funetions or neeessary processes, as a eenter, are grouped many minor aeeessory funetions, all helping to make more sueeessful the aeeom- 
plishment of the principal functions. While many of the lower animals have no cycs and no ears, and trust to more primitive mcans to diseover food or aroid enemies, the higher animals have extraordinarily complex organs for seeing and hearing, two functions which are accessory only to such a principal funetion as food-taking.

38. Differentiation of structure.- We hare seen, in our study of the slightly eomplex animals, how the body beeomes morc and morc complex in proportion to the degree in which the different lifc proeesses are divided or assigned to different parts of it for performance. With the gradually inereasing division of labor the body beeomes less homogcncous in strueture; a differentiation of strueture beeomes apparent and gradually inereases. 'The extent of the division of labor and the extcnt of the differcntiation of structure, or division of the body into distinet and different parts and organs, go hand in hand. An animal in which the division of labor is carried to an extreme is an animal in which complexity of structurc is extreme.

39. Anatomy and physiology.-Zoölogy, or the study of animals, is divided for eonvenicnee into serclal branches or phascs. 'The study of the classifieation of animals is called systematie zoölogy; the study of the development of animals from their beginning as a single eell to the time of their birth is called animal cmbryology; the study of the structure of animals is called animal anatomy, and the study of the performance of their life processes or funetions is callcd physiology. Becanse the whole field of zoölogy is so great, some zoölogists limit themselves exclusivcly to one of these phases of zoological study, and those who do not so definitely limit their study, at lcast give their speeial attention to a single phase, although all try to keep in touch with the state of knowledge in other phases. In earlicr days the study of the anatomy of animals and of their physiology werc held to be two very distinct lines of investigation, and the anatomists paid little attention to 
physiology and the physiologists little to anatomy. But we have seen how inseparably linked are structure and function. The structure of an animal is as it is because of the work it has to do, and the functions of an animal are performed as they are pcrformed because of the special structural condition of the organs which perform them. The study of the anatomy and the study of the physiology of animals can not be separated. To understand aright the structure of an animal it is necessary to know to what use the structure is put; to understand aright the processes of an animal it is necessary to know the structure on which the performance of the processes depends.

40. The animal body a machine.-The body of an animal may be well compared with some machine like a locomotive engine. Indeed, the animal body is a machine. It is a machine composed of many parts, cach part doing some particular kind of work for which a particular kind of structure fits it; and all the parts are dependent on each other and work together for the accomplishment of the total business of the machine. The locomotive must be provided with fuel, such as coal or wood or other readily combustible substance, the consumption of which furnishes the force or energy of the machine. The animal body must be provided with fuel, which is called food, which furnishes similarly the cnergy of the animal. Oxygen must be provided for the combustion of the fuel in the locomotive and the food in the body. The locomotive is composed of special parts: the firebox for the reception and combustion of fuel; the steam pipes for the carriage of steam; the wheels for locomotion; the smoke stack for throwing off of waste. The animal body is similarly composed of parts : the alimentary canal for the reception and assimilation of food the excretory organs for the throwing off of waste matter; the artcries and veins for the carriage of the oxygen and food-holding blood; the legs or wings for locomotion. 
The locomotive is an inorganic machine; the animal is an organic machine. There is a great and real differencc between an organism, a living animal, and a locomotive, an inorganic structure. But for a good understanding of the relation between function and structure, and of the composition of the body of the complex animals, the comparison of the animal and locomotive is very instructive.

41. The specialization of organs.-The organ for the performance of some definite function in one of the higher animals may be very complex. The corresponding organ in one of the lower animals for the performance of the same function may be comparatively simple. For example, the organ for the digestion of food is, in the case of the polyp, a simple cylindrical cavity in the body into which food enters through a large opening at the apical or frec end of the body. The digcstive organ of a cow is a long coiled tube, comprising many regions of distinct structural and physiological character and altogether extremely complicated. An organ in simple or primitive condition is said to be generalized; in complex or highly modified condition it is said to be specialized. That is, an organ may be modificd and complexly developed to perform its function in a spccial way, in a way differing in many particulars from the way the corresponding organ in some other animal performs the same general function. The specialization of organs, or thcir modification to perform their functions in spccial ways, is what makes animal bodies complex, for specialization is almost always in the line of complexity. Later we shall see more clcarly how specialization is brought about. For the present we may study one of the more important organs of the animal body for the sake of having concrete examples of some of the general statements made in this discussion of function and structure.

42. The alimentary canal.-The organ which has to do with the taking and digesting of food is called the ali- 
mentary canal. In some of the higher animals this is a very complex organ. In the cow, one of the cud-chewing mammals or ruminants, it consists of several distinct portions, which differ among themselves very much (Fig. 30). First, there is the mouth, or opening for the entrance of the food. The mouth is supplied with tceth for biting off and chewing the food, with a tongue for manipulating it, and witl taste papillæ situated on the tongue and palate for determining the desirability of the food. Into the mouth a peculiar fluid (the saliva) is poured by ccrtain glands, organs accessory to the alimentary canal. The herbage bitten off, mixed witl saliva, and rolled by the tonguc into a ball, passes back through a narrow tubc, the cosophagus, and into a sac called the rumen, or paumch. Here it lies until the cow ccases for the while to takc in food, when it passes back again through the cesophagus and into the mouth for mastica-

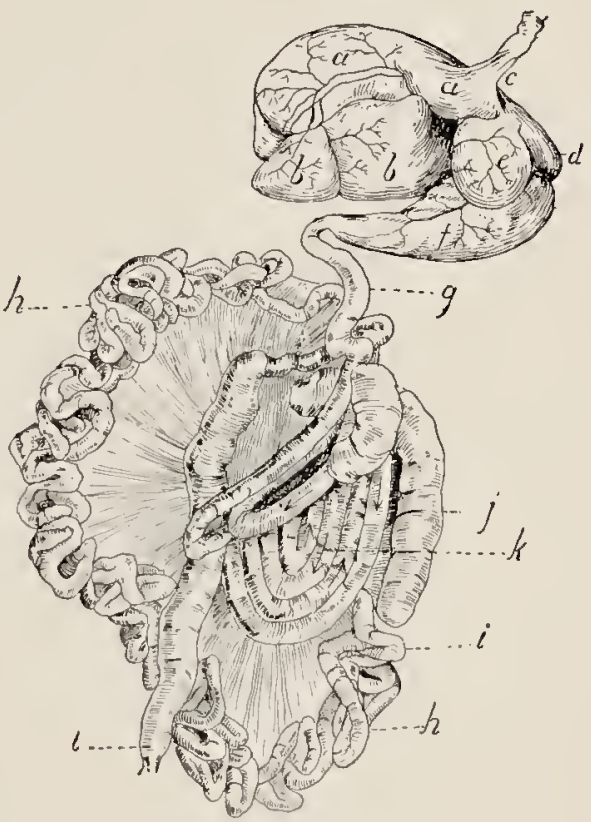

Fra. 30.-Alimentary cunal of the ox (after CoLIN and MÜldLER)。 $a$, rumell (left hemsiphere); $b$, rumen (right hemisphere) $c$, iusertion of resoplagus ; $d$, reticulum ; $e$, omasum ; $f$, abomasum ; $g$, duodenum; $h$ and $i$, jejunnm and ileum; $j$, cxcum; $k$, colon, with its various convolutions; $l$, rectum.

tion. After being masticated it again passes downward through the oesophagus, and entcrs this time another sac called the reticulum, lying next to the rumen. From here it passes into another sac-like portion of the alimentary canal called the omasum, whcre it is strained through numerous leaf-like folds which line the walls of this part of the canal. From here the food passes into a fourth 
sae-like part of the eanal, ealled the abomasum. Here the process of digestion goes on. 'The four saes-rumen, reticulum, omasum, and abomasum-are ealled stomachs, or they may be eonsidercd to be four ehamber's forming one large stomach. In the abomasum, or digesting stomach, digestive fluids are poured from glands lining its walls, and the food becomes converted into a liquid called ehyle. The chyle passes from the stomaeh into a long, narrow, tubular portion of the eanal ealled the intestine. The intestine is very long, and lies coiled in a large mass in the body of the cow. The intestine is divided into distinet regions, which vary in size and in the charaeter of the inmer wall. These parts of the intestine have names, as duodenum, jejunum, ileum, eæeum, colon, ete. Part of the intestine is lined inside with fine papillæ, whieh take up the chyle (the digested food) and pass it through the walls of the intestine to other special organs, which pass it on to the blood, with whieh it becomes mixed and carried by an elaborate system of tubes to all parts of the body. Part of the grass taken into the alimentary eanal by the eow can not be digested, and must be got rid of. This passes on into a final posterior part of the intestine called the reetum, and leaves the body through the anus or posterior opening of the alimentary canal. The whole canal is more than twenty times as long as the body of the cow; it is eomposed of parts of different shape; its walls are supplied with museles and blood-vessels; the inner lining is eovered with folds, papillæe, and gland eells. It is altogether a highly speeialized organ, a strueturally eomplex and claborately funetioning organ.

Let us now examinc the alimentary eaual, or organ of digestion, in some of the simpler animals.

The Protozoa, or simplest animals, have no speeial organ at all. When the surface of the body of an Amoba comes into contaet with an organic partiele which will serve as food, the surface becomes bent in at the point of its con- 
taet with the food partiele, and the body substance simply incloses the food (Fig. 3). Food is taken in by the surface. The whole outer surface of the body is the foodtaking organ. In the simplest many-celled animals, the sponges, there is no speeial food-taking and digestive organ. Each of the eells of the body takes in and assimilates food for itself. The sponge is like a great group of Amobce holding fast to eaeh other, but each looking out for its own neeessities. Among the polyps, however, there is a definite organ of digestion-that is, food is only taken and digested by certain parts of the body. The simple polyp's body (Fig. 31 ) is a cylinder or vase closed at one end and open at the other end, and attached by the closed end to a rock. The opening is usually of less diameter than the diameter of the body, and it is surrounded by a number of tentaeles, whose

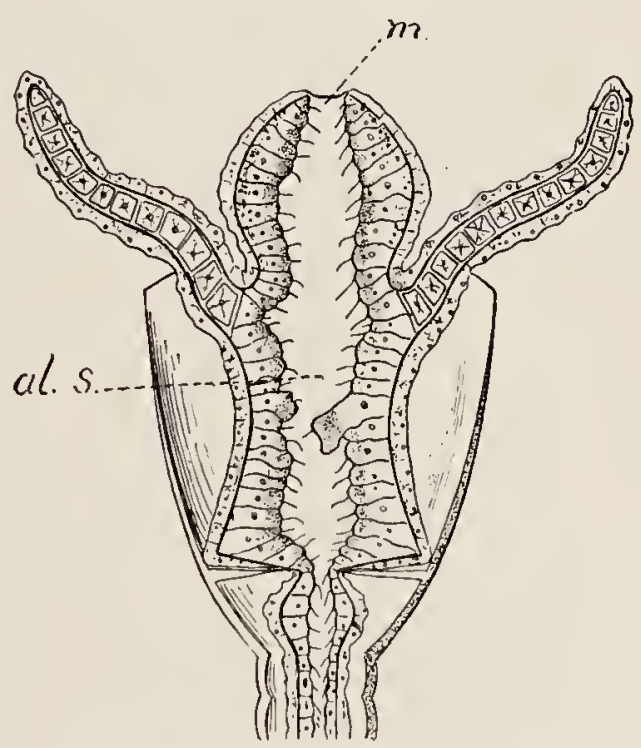

FIt. 31.- Obelia sp., a simple nolyp; vertical section, highly magnifled. m, month opening; al. s., alimentary sac. - After PAIKER and 11ASWELL.

function it is to seize the food and eonvey it to the mouth opening. There arc, of eourse, no teeth, no tongue, nonc of the various parts whieh are in or are part of the mouth of the higher animals. The polyp's mouth is simply a hole or opening into the inside of the body. This body eavity, or simplest of all stomaehs, is simply the eylindrieal or vase-shaped hollow spaee inelosed by the body wall. This space extends also into the tentacles. There is no other opening, no posterior or anal opening. We ean not 
speak of an œesophagus or intestine in eonnection with this most primitive of alimentary sacs. The cells which line the sacs show some differentiation; some are gland cells and secrete digestive fluids; some are amcboid and are provided with pseudopods or flagella for seizing bits of food. The food eaught by the tentacles comes into the alimentary sac through the opening or primitive mouth, and

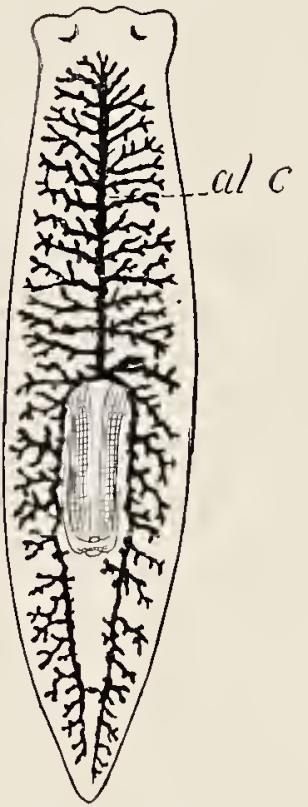

Fia. 32.-Diagrammatic sketch of a flatworm (Planaria), showing the branched alimentary canal, al. c.Aftir JIJIMA and IATSIEK.

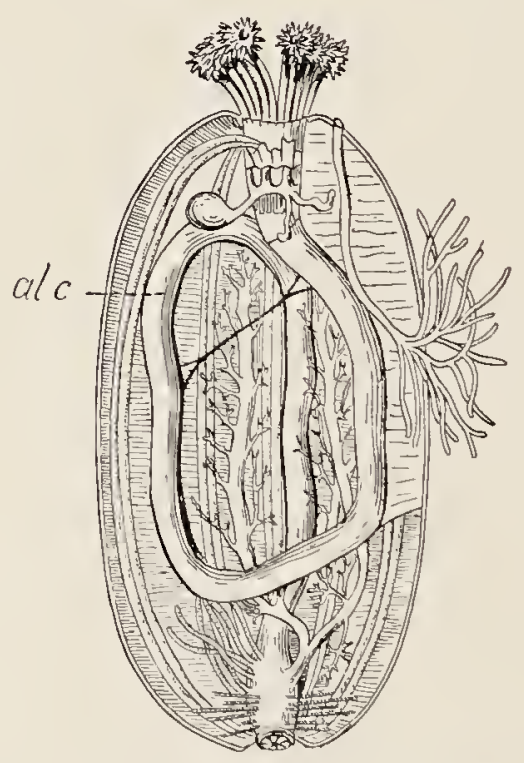

FIG. 33.-Sea-cnoumber (Holothurian) dissected to show alimentary canal, al. c.-After Leuchant.

what of it is digestible is, by the aid of the gland cells and the amoboid eells, taken $u p$ and assimilated, while the rest of it is carried out by water currents again through the single opening.

In the flatworms (Fig. 32) like Planaria (small, thin, flattened worms to be found in the mud at the bottom of fresh-water ponds) the mouth opens into a short, narrow tube which may be ealled an cesophagus. The osophagus 
connects the mouth with the rest of the alimentary canal, which gives out many side branches or diverticula, which are themselves branched, so that the alimentary sac or stomach is a system of ramifying tubes extending from a central main tube to all parts of the body of the worm. There is no anal opening. In the round or thread worms, of which the deadly Trichina is an example, the alimentary canal is a simple straight tube with both anterior or mouth opening and posterior or anal opening. In the seaurchins and sea-cucumbers (Fig. 33) the alimentary canal is a simple tube with two openings, but it is longer than the body betwecn mouth and anus, and so is more or less bent or coiled. In the earthworm the alimentary canal (Fig. 34), although a simple straight tube rumning through the body, plainly shows a differentiation into particular regions. Behind the mouth opening the alimentary tube is large and thick - walled and is called the pharynx; behind the pharynx it is narrower and is called the oosophagus. Behind the osophagus it expands to form a rounded, thin-walled chamber called the crop, and just behind this there is another rounded but very thick-walled cham- Fig. 34,-Earthworm dissected ber called the gizzard. From the

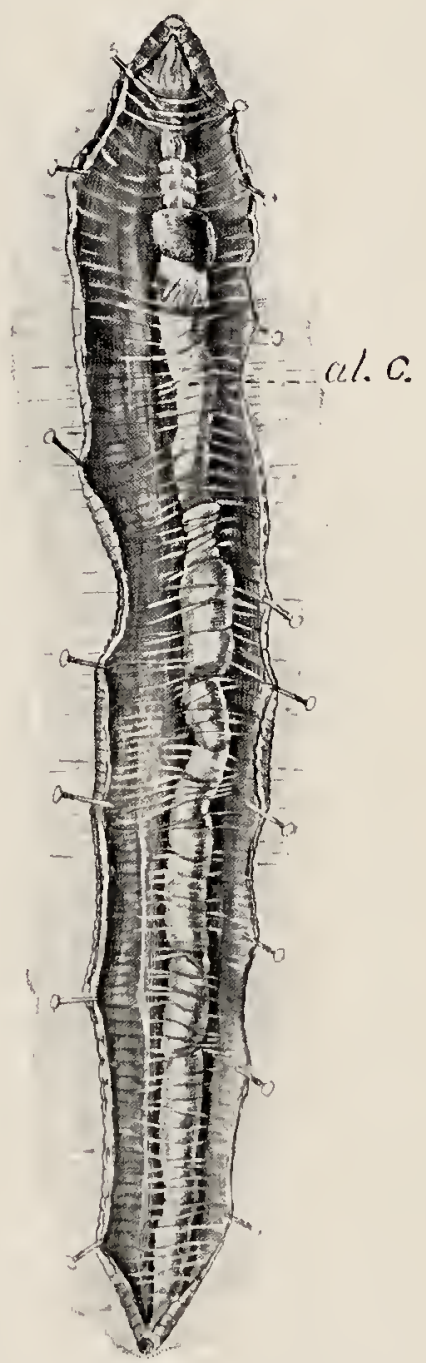
gizzard back the alimentary canal is to show alimentary canal, al. $c$. about uniform in sizc, being rather wide and having thick, soft walls. This portion of it is called the intestine. The 
posterior part of the intestine, called the rectum, leads to the anal opening. There is some differentiation of the inner surface of the canal. In the great group of mollusks, of which the common fresh-water clam or mussel is an example, the alimentary canal (Fig. 35) shows much variation. The microscopic plants, which are the food of the mussel, are taken in through the mouth and pass into a short osophagus, thence into a wide stomach and there digested. Behind the stomach is a long, much-folded, narrow intestine which winds about through the fleshy "foot" and finally reaches the surface of the body, and has an anal opening at a point opposite the position of the mouth.

Among the insects there is a great range in degree of complexity of the alimentary canal. The digestive organs are, however, in most insects in a condition of high specialization. The month opening is provided with well-developed

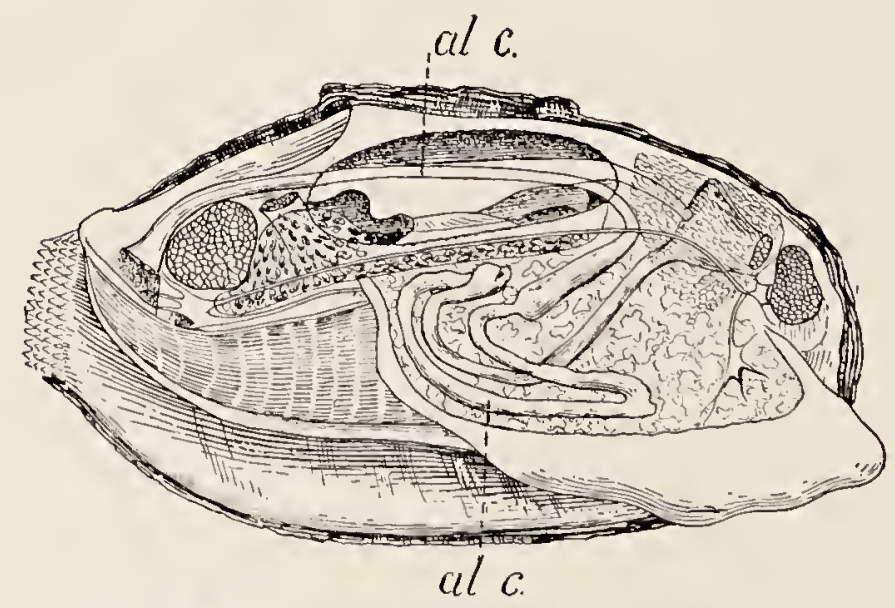

Fis. 35. - lond mussul diseceted to show alimentary canal, al, c.-After llatsiek and Cors.

biting and masticating or piereing and sucking mouth parts; pharyux, wsophagus, stomach, and intestine arc always differentiated and sometimes greatly modified. In the common cockroach, for example (Fig. 36), the mouth has a complicated food-getting apparatus, and the canal, which 
is mueh longer than the body of the inseet, and henee mueh bent and eoiled, eonsists of a pharynx, œsophagus, fore-stomach or proventrieulus, true digesting stomaeh or ventriculus, intestine, and rectum whieh opens at the postcrior tip of the body. The inner lining of the eanal shows mueh differentiation in the different parts of the canal, and there are numerous aeeessory glands conneeted with various parts of the canal.

Finally, among the highest animals, the vertebrates, we find still morc elaborate specialization of the alimentary eanal. As an example the alimentary eanal of a eow has already been described in detail.

13. Stable and variable characteristics of an organ. - In

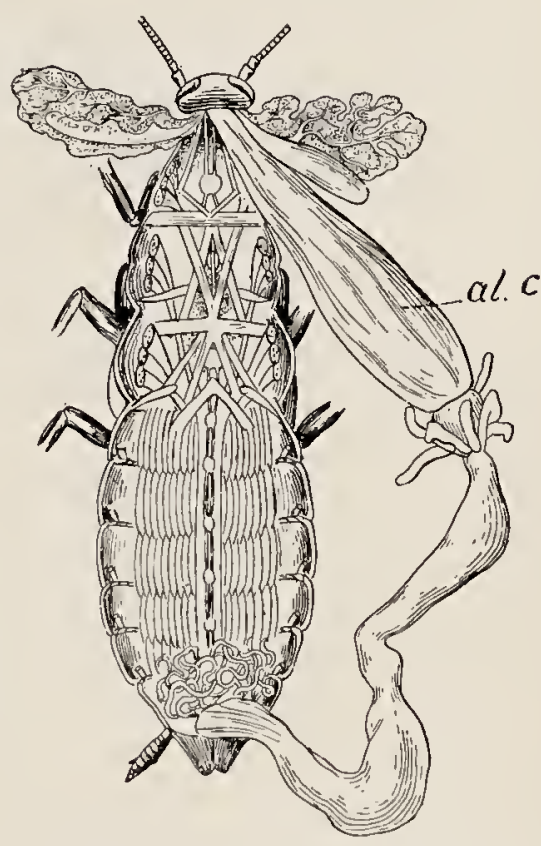

FIG. 36.-Cockroach dissected to show alimentary canal, al.c.-After 11ATSIIEK and Cors. spite of all this variation in the strueture and general charaeter of the alimentary eanal, there are certain charaeteristies which arc features of all alimentary canals. In the examination of an organ we must ever distinguish betwcen its so-called constant or stable charaeteristies and its ineonstant or variable characteristies. The constant eharaeteristics are the fundamentally essential ones of the organ; the variable ones are the speeial eharaeteristies which adapt the organ for the peculiar habits of the animal possessing it-habits which may differ very much from those of some other animal of similar size, similar distribution, similar abundance.

\section{Stable and variable characteristics of the alimentary} canal.-A tiger or a lion has an alimentary eanal not more 
than three or four times the length of its body, while a sheep has an alimentary eanal twenty-eight times as long as its body. The tiger is earnivorous; the sheep herbivorous. Assoeiated with the different food habits of the two animals is a striking differenee in the alimentary eanals. Animals like the horse or eat, whieh ehew their food before swallowing it, have a slender cesophagus; animals like snakes whieh swallow their food whole have a wide osophagus. Birds, that have no teetl and henee ean not mastieate or grind their food in their mouths, usually have a speeial grinding stomaeh, the gizzard, for this purpose. And so we might eite innumerable examples of these ineonstant or variable charaeteristies of the alimentary eanal. On the other hand, the alimentary eanals of all the many-eelled animals exeept the lowest agree in eertain important characteristies. Each alimentary eanal has two openings, one for the ingress of food and one for the exit of the indigestible portions of the matter taken in, and the eanal itself stretehes through the body from mouth to anus as a tube, now narrow, now wide, now suddenly expanding into a sae or giving off lateral diverticula, but always simply a lumen or hollow inelosed by a flexible muscular wall. The inner lining of the wall is provided with seereting and absorbing structures. Indeed, we can reduce the essential elaracters of the alimentary eanal to even more simple features. The organ of digestion or assimilation of all the many-celled animals is merely a surfaee with which food is brought into contaet, and which has the power of digesting this food by means of digestive seeretions, and of absorbing the food when digested. This surface is small or yreat in extent, depending upon the amount of food neeessary to the life of the animal and the diffieulty or readiness with whieh the food can be digested. This surface miglit just as well be on the ontside of the animal's body as on the inside, if it were eonvenient. In faet, it is on the outside of some animals. Among the Protozoa the 
digesting surface is simply the external surface of the body. And not alone among the one-eelled animals. Many of the parasitie worms which live in the bodies of other animals, and the larvæ or "grubs" of many inseets which lie in the tissues of plants bathed by the sap, have no inner alimcntary eanal, but take food through the outer surface of the body. But in these cases the food is ready for immediate absorption, so that no special treatment of it is necessary, hence no eomplex struetures are required.

Even were no such speeial treatment of the food necessary in the ease of the larger animals, it would still be im-

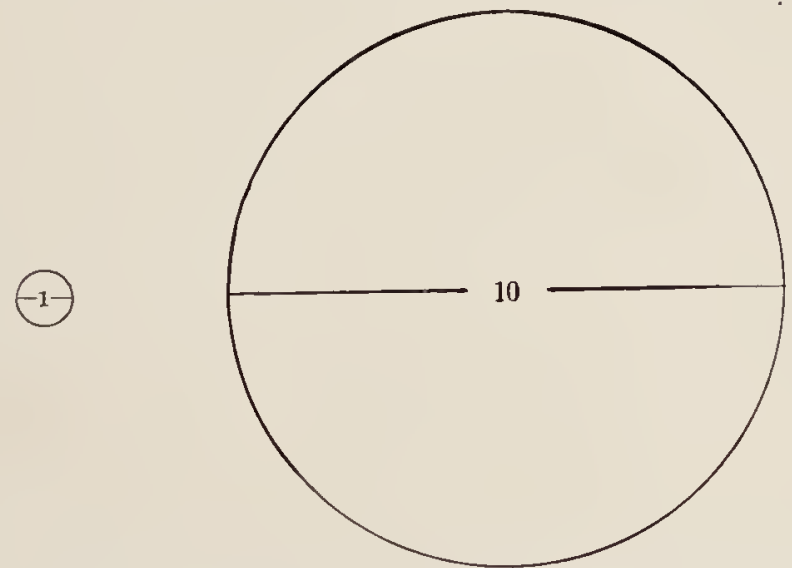

FIG. 3\%.-Diagram illustrating increase of volume and surface with increase of diameter of sphere.

possible for the simple external surface of the body to serve for food absorption, beeause of the well-known relation betwcen the surface and the mass of a solid body. When a solid body in the form of a sphere inereases in size, its mass or volume inereases as the eube of the diamcter, while the surface increases only as the square of the diameter (Fig. 37). The external surface of minute animals a few millimeters in diameter ean take up enough food to supply the whole body mass. But among large animals this foodgetting surface is inereased as the square of the diameter of 
the body, while the volume or food-using surface of the body is increased as the cube of its diameter. 'The food supplying can not keep pace with the food using. Hence it is absolutely essential that among large animals the food-taking surface be increased so that it will remain in the same favorable proportion to the mass of the animal as is the case among the minute animals, where the simple external body surface is sufficient to obtain all the food necessary. This increase of surface, without an accompanying increase of size of the animal, is accomplished by having the digesting and assimilating surface inside the body and by having it greatly folded. The surface of the alimentary canal is, after all, simply a bent-in continuation of the outer surface of the body. It is open to the outside of the body by two openings, and wholly closed (except by its porosity) to the true inside of the body. By the bending and coiling of the alimentary canal, and by the repeated folding of its inner wall, the alimentary surface is greatly increased. The necessity for this increase accounts largely for the complexity of the alimentary canal.

But it is not alone this necessity for increased surface that accounts for the great spccialization of the alimentary canal in such animals as the insects and the vertebrates. The structural differences in different portions of the canal, resulting in the differentiation of the canal into distinct parts, or the differentiation of the whole organ into distinct subordinate organs, each with a special work or function to perform, are the result of the necessity for the special manipulation of the special kinds of foods taken. Animals which feed on other animals must have mouth structures fit for seizing and rending their prey, and the alimentary canal nust be specially modified for the digestion of flesh. Animals which feed on regetable substances must have special modifications of the alimentary canal quitc different from those of the carnivores. Some insects, like the mosquito, take only liquid food, the sap of plants, or the blood 
of animals; others, like the weevils, feed on the hard, dry substance of seeds and grains; others, like the grasshoppers and caterpillars, eat green leaves; and still others eat other insects. The alimentary canal of each of these kinds of insects differs more or less from that of the other kinds. The specialization of the alimentary canal depends then upon the necessity for a large food-digesting and absorbing surface, and on the complex treatment of the food. The character of this specialization in each case depends upon the special kind or quality of food taken by the animal in question.

45. The mutual relation of function and structure,-The structure of an animal depends upon the manner in which the life processes or functions of the animal arc performed. If the functions are performed in a complex manner, the structure of the body is complex; if the functions are performed in simple manner, the body will be simple in structure. With the increase in degree of the division of labor among various parts of the body, there is an increase in definiteness and extent of differentiation of structure. Each part or organ of the body becomes more modified and better fitted to perform its own special function. A peculiar structural condition of any part of the body, or of the whole body of any animal, is not to be looked on as a freak of Nature, or as a wonder or marvel. Such a structure has a significance which may be sought for. The unusual structural condition is associated with some special habit or manner of performance of a function. Function and structure are always associated in Nature, and should always be associated in our study of Nature. 


\section{CHAPTER V}

\section{THE LIFE CYCLE}

46. Birth, growth and development, and death.-Certain phenomena are familiar to us as oeeurring ineritably in the life of every animal. Each individual is born in an immature or young eondition; it grows (that is, it inereases in size), and develops (that is, changes more or less in strueture), and dies. These phenomena oeeur in the sueeession of birth, growth and development, and death. But before any animal appears to us as an independent individualthat is, outside the body of the mother and outsicle of an egg (i. e., before birth or hatehing, as we are aeeustomed to eall such appearance) -it has already undergone a longer or shorter period of life. It has been a new living organism hours or days or months, perhaps, before its appearanee to us. 'This period of life has been passed inside an egg, or as an egg or in the egg stage, as it is variously termed. The life of an animal as a distinet organism begins in an egg. And the true life eyele of an organism is its life from egg through birth, growth and development, and maturity to the time it produees new organisms in the condition of eggs. The life eyele is from egg to egg. Birth and growth, two of the phenomena readily apparent. to us in the life of every animal, are two phenomena in the true life eyele. Death is a third inevitable phenomenon in the life of eaeh individual, but it is not a part of the eyele. It is something outside.

4\%. Life cycle of simplest animals.-The simplest aninals have no true egg stage, nor perhaps have they any true 
death. The new Amobe are from their beginning like the full-grown Amoba, except as regards size. And the old Amoba does not die, beeause its whole body continues to live, although in two parts-the two new Amoba. The life eyele of the simplest animals ineludes birth (usually by simple fission of the body of the parent), growth, and some, but usually very little, development, and finally the reproduetion of new individuals, not by the formation of eggs, but by direet division of the body.

48. The egg.-In our study of the multiplieation of animals (Chapter III) we learned that it is the almost univer-
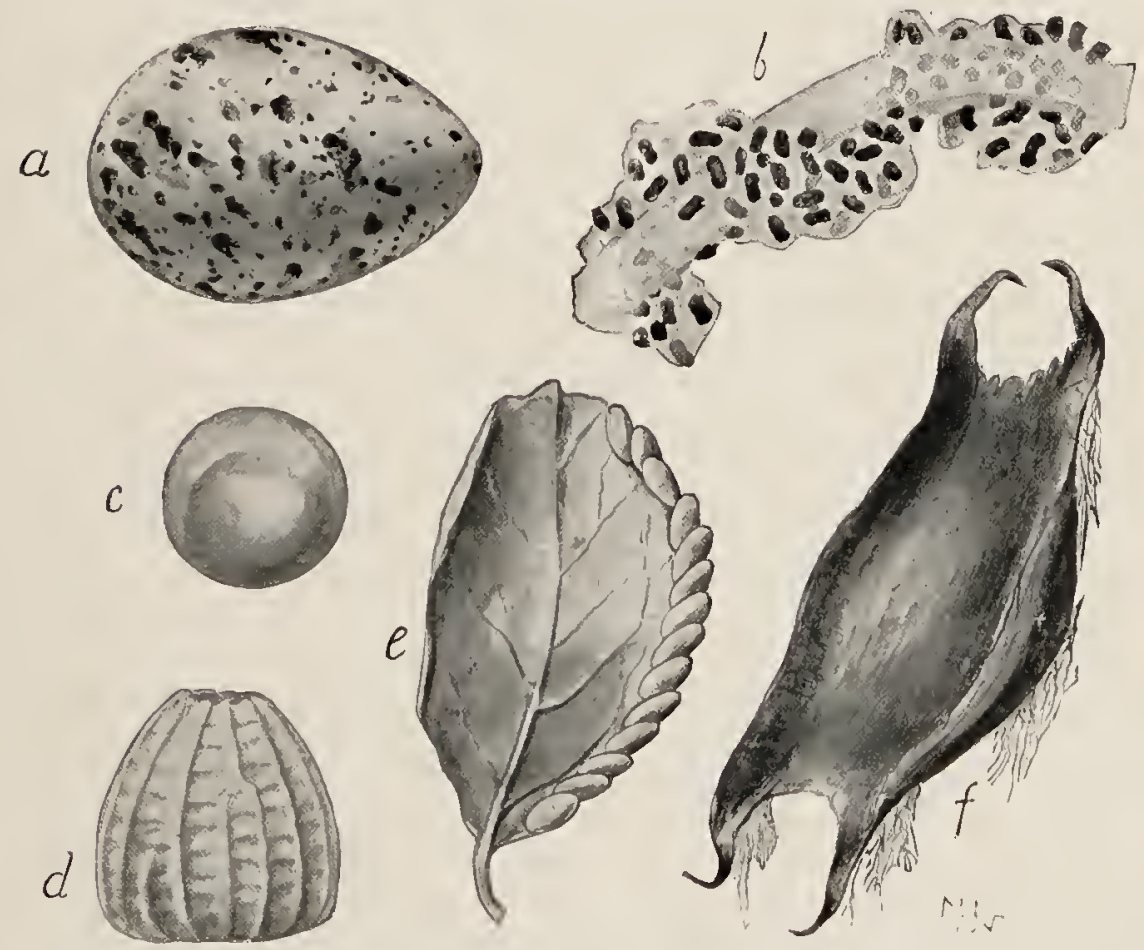

FIG. 38.-Egrrs of different animals showing variety in external appearance. $\alpha$, egg of bird; $b$, eggs of toad; $c$, egg of fish ; $d$, egg of butterily; $e$, eggs of katydid on leaf; $f$,egrg-case of skate.

sal rule among many-celled animals that eaeh individual begins life as a single eell, which has been prodneed by the 
fusion of two germ eells, a sperm eell from a male individual of the speeies and an egg eell from a female individual of the speeies. The single eell thus formed is ealled the fertilized egg eell, and its subsequent derelopment results in the formation of a new individual of the same speeies with its parents. Now, in the development of this eell into a new animal, food is neeessary, and sometimes a eertain amount of warmth. So with the fertilized egg eell there is, in the ease of all animals that lay eggs, a greater or less amount of food matter-food yolk, it is ealled-gathered about the germ cell, and both germ eell and food yolk are inclosed in a soft or hara wall. Thus is eomposed the egg as we know it. 'The hen's egg is as large as it is beeanse of the great amount of food yolk it eontains. The egg of a fish as large as a hen is much smaller than the hen's egg; it eontains less food yolk. Eggs (Fig. 38) may vary also in their external appearanee, beeause of the different kinds of membrane or shells which may inelose and proteet them. Thus the frog's eggs are inelosed in a thin membrane and imbedded in a soft, jelly-like substanee; the skate's egg has a tougl, dark-brown leathery inelosing wall ; the spiral egg of the bull-head sharks is leathery and eolored like the dark-olive seaweeds among whieh it lies; and a bird's egg has a hard shell of earbonate of lime. Bnt in eaeh ease there is the essential fertilized germ eell; in this the eggs of hen and fish and butterfly and eray-fish and worm are alike, however mueh they may differ in size and external appear:mee.

49. Embryonic and post-embryonic development.-Some animals do not lay eggs, that is they do not deposit the fertilized egg eell outside of the body, but allow the development of the new individual to go on inside the body of the mother for a longer or shorter period. All the mammals and some other animals have this habit. When sueh an animal issues from the body of the mother, it is said to be born. When the developing animal issues from an egg 
which has been deposited outside the body of the mother, it is said to hateh. 'The animal cut birth or at time of hatehing is not yet fully developed. Only part of its development or period of immaturity is passed within the egg or within the body of the mother. That part of its life thus passed within the egg or mother's body is ealled the embryonic life or embryonie stages of development; while that period of development or immaturity from the time of birth or hatehing until maturity is reached is ealled the post-embryonic life or post-embryonic stages of development.

50. First stages in development.-The embryonic development is from the beginning up to a certain point practically identical for all many-celled animals - that is, there are cer-

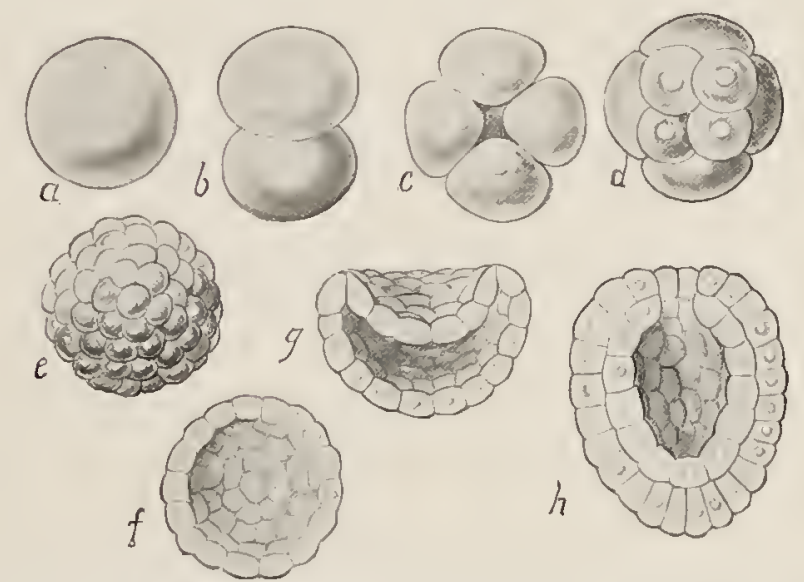

Fra. 39. - First stages in embryonie development of the pond smail (Lymmarns), $a$, erge cell ; $b$, first cleavage : $c$, second cleavage ; $d$, third clenvage ; e, after numerons cleavages; $f$, blastula (in section); $g$, gastrula, just forming (in rection); $h$, gastrula, completed (in section).-After RABL.

tain prineipal or constant characteristics of the beginning development which are present in the development of all many-eelled animals. The first stage or phenomenon of development is the simple fission of the germ eell into halves (Fig. 39, b). These two daughter cells next divide so that there are four cells (Fig. 39, c); each of these divides, and this division is repeated until a greater or lesser num- 
ber (varying with the various specics or groups of ani mals) of cells is produced (Fig. 39, d). The phenomenon of repeated division of the germ cell is called cleavage, and this cleavage is the first stage of development in the case of all many-celled animals. The first division of the germ cell produces two equal cells, but in some of the later divisions the new cells formed may not be equal. In some animals all the cleavage cells are of equal size; in some there are two sizes of cells. The germ or embryo animal consists now of a mass of few or many undifferentiated primitive cells lying together and nsually forming a sphere (Fig. 39, e), or perhaps separated and scattered through the food yolk of the egg. The next stage of development is this: the cleavage cells arrange themselves so as to form a hollow sphere or ball, the cells lying side by side to form the outer circumferential wall of this hollow sphere (Fig. $39, f)$. This is called the blastule or blastoderm stage of development, and the embryo itself is called the blastula or blastoderm. This stage also is common to all the manycelled animals. The next stage in embryonic development is formed by the bending inward of a part of the blastoderm cell layer, as shown in Fig. 39, $g$. This bending in may producc a small depression or groove; but whatever the shape or extent of the sunken-in part of the blastoderm, it results in distinguishing the blastoderm layer into two parts, a sunken-in portion called the endoblast and the other unmodificl portion called the ectoblast. Endo-means within, and the cclls of the cndoblast usually push so far into the original blastoderm cavity as to come into contact with the cells of the cetoblast and thus oblitcratc this cavity (1Fig. 39, $h$ ). 'This third well-marked stage in the cmbryonic devclopment is called the gastrula $*$ stagc, and it also

* This gastrula stage is not always formed by a bending in or invagination of the blastoderm, but in some animals is formed by the splitting off or delamination of cells from a definite limited region of 
oeeurs in the development of all or nearly all many-eelled animals.

51. Continuity of development.-In the ease of a few of the simple many-eelled animals the embryo hatehes-that is, issnes from the egg at the time of or very soon after reaching the gastrula stage. In the higher animals, however, development goes on within the egg or within the body of the mother until the embryo beeomes a eomplex body, eomposed of many various tissues and organs. Almost all the development may take plaee within the egg,
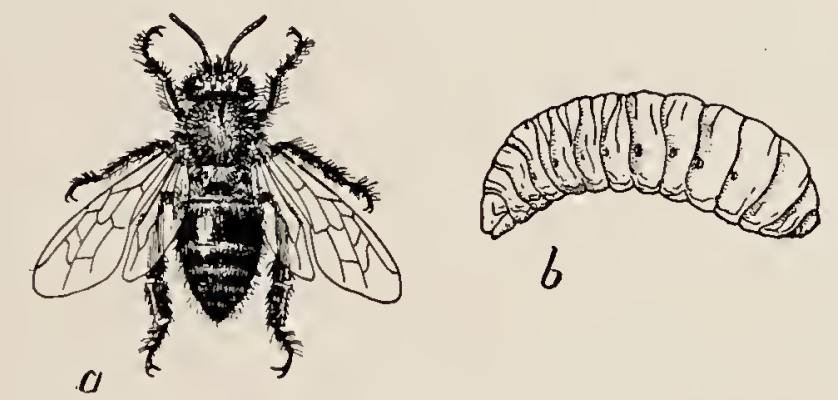

Fig. 40.-Honey-bee. $a$, adult worker ; $b$, young or larval worker.

so that when the young animal hatehes there is neeessary little more than a rapid growth and inerease of size to make it a fully developed, mature animal. This is the ease with the birds: a ehieken just hatehed has most of the tissues and organs of a full-grown fowl, and is simply a little hen. But in the ease of other animals the young hatehes from the egg before it has reached sueh an adranced stage of development; a young star-fish or young erab or young honey-bee (Fig. 40) just hatehed looks very different from its parent. It has yet a great deal of development to undergo before it reaches the struetural condition of a fully developed and fully grown star-fish or erab or bee. Thus the development of some animals is almost

the blastoderm. Our knowledge of gastrulation and the gastrula stage is yet far from complete. 
wholly embryonic development-that is, development within the egg or in the body of the mother-while the development of other animals is largely post-embryonie or larval development, as it is often ealled. There is no important differenee between embryonie and post-embryonie development. The development is eontinucus from egg eell to mature animal, and whether inside or ontside of an egg it goes on regularly and uninterruptedly.

52. Development after the gastrula stage.-The eells whieh eompose the embryo in the eleavage stage and blastoderm stage, and even in the gastrula stage, are all similar; there is little or no differentiation shown among them. But from the gastrula stage on development ineludes three important things: the gradual differentiation of eells into various kinds to form the various kinds of animal tissnes; the arrangement and grouping of these eells into organs and body parts; and finally the developing of these organs and body parts into the speeial eondition eharaeteristie of the speeies of animal to whieh the dereloping indiridual belongs. From the primitive undifferentiated eells of the blastoderm, development leads to the speeial eell types of musele tissue, of bone tissue, of nerve tissne; and from the generalized eondition of the embryo in its early stinges development leads to the speeialized condition of the body of the adnlt animal. Development is from the general to the speeial, as was said years ago by the first great student of development.

53. Divergence of development.-A star-fisl, a beetle, a love, and a horse are all alike in their beginning--that is, the body of each is eomposed of a single eell, a single struetural mit. And they are all alike, or very mueh alike, through several stages of development; the body of eaeh is first a single eell, then a number of similar undifferentiated eells, and then a hollow spliere eonsisting of a single layer of similar undifferentiated eells. But soon in the course of development the embryos begin to differ, and as 
the young animals get further and further along in the course of their derelopment, they become more and more differcnt until cach finally reaches its fully developed mature form, showing all the great structural differences between the star-fish and the dove, the beetle and the horse. That is, all animals begin development alike, but gradually diverge from each other during the course of development.

There are some extremely interesting and significant things about this divergence to which attention should be given. While all animals are alike structurally* at the beginning of development, so far as we can see, they do not all differ at the time of the first divergence in development. This first divergence is only to be noted betwcen two kinds of animals whieh belong to different great groups or classes. But two animals of different kinds, both belonging to some one great group, do not show differences until later in their development. This can best be understood by an example. All the butterflies and beetles and grasshoppers and flies belong to the great group of animals ealled Insecta, or insects. There are many different kinds of insects, and these kinds ean be arranged in subordinate groups, such as the Diptera, or flies, the Lepidoptera, or butterflies and moths, and so on. But all have certain struetural charaeteristics in eommon, so that they are eomprised in one great gronp or elass-the Inseeta. Another great group of animals is known as the Vertebrata, or back-boned animals. 'The elass Vertebrata inelndes the fishes, the batrachians, the reptiles, the birds, and the mammals, eaelı eomposing a subordinate group, but all eharacterized by the possession of a back-

* They are alike structurally, when we eonsider the cell as the unit of animal structure. That the egg cells of different animals may differ in their fine or ultimate strueture, seems certain. For eueh one of these egg cells is destined to become some one kind of animal, and no other; eaeh is, indeed, an individual in simplest, least developed condition of some one kind of animal, and we must believe that differenee in kind of animals depends upon differenee in structure in the egg itself. 
bone, or, more accurately speaking, of a notochord, a backbone-like structure. Now, an insect and a vertebrate diverge very soon in their development from each other; but two insects, such as a beetle and a honey-bee, or any two vertebrates, such as a frog and a pigeon, do not diverge from each other so soon. That is, all vertebrate animals diverge in one direction from the other great groups, but all the members of the great group keep together for some time longer. Then the subordinate groups of the Vertebrata, such as the fishes, the birds, and the others diverge, and still later the different kinds of animals in each of these groups diverge from each other. In the illustration (Fig. 41) on the opposite page will be seen pictures of the embryos of various vertebrate animals shown as they appear at different stages or times in the course of development. The embryos of a fish, a salamander, a tortoise, a bird, and a mammal, representing the five principal groups of the Vertebrata, are shown. In the upper row the embryos are in the earliest of all the stages figured, and they are very much alike. There are no distinctive characteristics of fish or bird. Yet there are distinctive characteristics of the great class Vertebrata. Any of these embryos could readily be distinguished from an embryonic insect or worm or sea-urchin. In the second row there is begimning to be manifest a divergence among the different embryos, although it would still be a difficult matter to distinguish certainly which was the young fish and which the young salamander, or which the young tortoise and which the young bird. In the bottom row, showing the animals in a later stage of development, the divergence has proceeded so far that it is now plain which is a fish, which batrachian, which reptile, which bird, and which mammal.

54. The laws or general facts of development.-That the course of development of any animal from its beginning to fully developed adult form is fixed and certain is readily seen. Every rabbit develops in the same way ; every grass- 

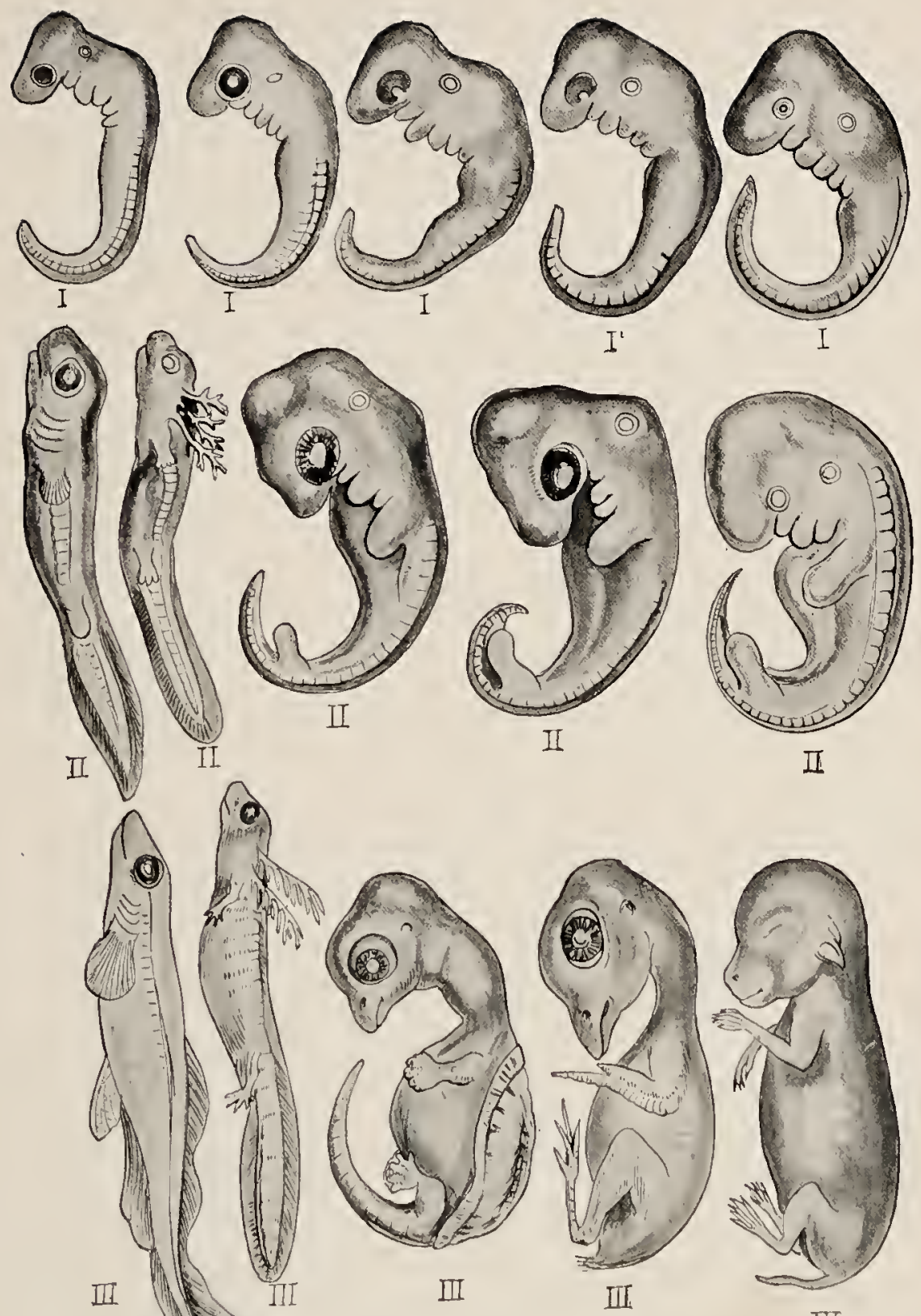

Fish Salamander
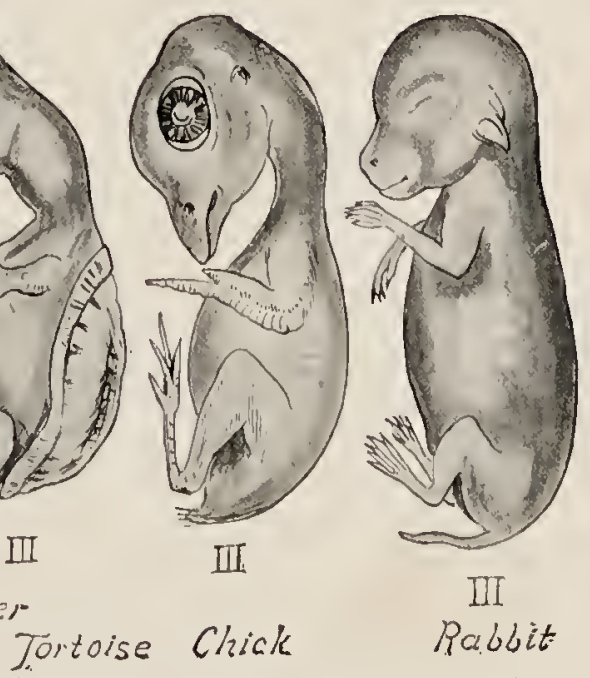

FIG. 41.-Different vertebrate animal in successive cmbryonic stages. I, first or earliest of the stages figured: II. second of the stages; III, third or latest of the stages.-After HAEcribl. 
hopper goes through the same developmental ehanges from single egg eell to the full-grown active hopper as every other grasshopper of the same kind-that is, development takes place aeeording to eertain natural laws, the laws of animal development. 'These laws may be roughly stated as follows: All many-eelled animals begin life as a single eell, the fertilized egg eell ; each animal goes through a eertain orderly series of developmental ehanges whieh, aecompanied by growth, leads the animal to change from single eell to the many-eelled, complex form eharacteristie of the speeies to whieh the animal belongs; this development is from simple to eomplex structural condition; the development is the same for all individuals of one speeies. While all animals begin development similarly, the course of development in the different groups soon diverges, the divergenee being of the nature of a branehing, like that shown in the growth of a tree. In the free tips of the smallest branehes we have represented the various speeies of animals in their fully developed eondition, all standing clearly apart from eaeh other. But in traeing baek the development of any kind of animal, we soon eome to a point where it very mueh resembles or beeomes appirently identieal with some other kind of animal, and going further baek we find it resembling other animals in their young eondition, and so on until we eome to that first stage of development, that trunk stage, where all animals are strueturally alike. To be sure, any animal at any stage in its existence differs absolutely from any other kind of animal, in that it ean develop into only its own kind of animal. There is something inherent in eaeh developing animal that gives it an identity of its own. Althougl in its young stages it may be indistinguishalble from some other kind of animal in its young stages, it is sure to eome out, when fully developed, an individual of the same kind as its parents were or are. The young fish and the young salamander in the upper row in Fig. 41 are indistinguishably alike, but one embryo 
is sure to develop into a fish and the other into a salamander. This certainty of an cmbryo to become an individual of a certain kind is called the law of heredity. Viewed in the light of development, there must be as grcat a difference betwcen one egg and another as betwcen one animal and another, for the greater differcnce is included in the less.

55. The significance of the facts of development.-The significance of the developmental phcnomena is a matter about which naturalists have yet very much to learn. It is believed, however, by practically all naturalists that many of the various stages in the development of an animal correspond to or repeat the structural condition of the animal's ancestors. Naturalists bclicve that all backboned or vertebrate animals are related to cach other through being descended from a common ancestor, the first or oldest backboned animal. In fact, it is because all these backboned animals- the fishes, the batrachians, the reptiles, the birds, and the mammals-have descended from a common ancestor that they all have a backbone. It is believed that the descendants of the first backboned animal have in the course of many generations branched off little by little from the original type until there came to exist very real and obvious differences among the backboned animals-differences which among the living backboned animals arc familiar to all of us. The course of development of an individual animal is believed to be a very rapid and cvidently much condensed and changed, recapitulation of the history which the specics or kind of animal to which the developing individual belongs has passed through in the coursc of its descent through a long scries of gradually changing ancestors. If this is truc, then we can readily understand why the fish and the salamander and tortoise and bird and rabbit are all alike in their earlier stages of development, and gradually come to differ more and more as they pass through later and later developmental stages. 
56. Metamorphosis. - While a young robin when it hatehes from the egg or a young kitten at birth resembles its parents, a young star-fish or a young erab or a young butterfly when hatehed does not at all resemble its parents. And while the young robin after hatehing beeomes a fully grown robin simply by growing larger and undergoing eomparatively slight developmental ehanges, the young star-fish or young butterfly not only grows larger, but undergoes some very striking developmental ehanges; the body ehanges very mueh in appearanee. Marked ehanges in the body of an animal during post-embryonie or larval development eonstitute what is ealled metamorphic development, or the animal is said to undergo or to show metamorphosis in its development. Metamorphosis is one of the most interesting features in the life history or development of animals, and it ean be, at least as far as its external aspeets are eoneerned, very readily observed and studied.

5\%. Metamorphosis among insects.-All the butterflies and moths show metamorphosis in their development. So do many other inseets, as the ants, bees, and wasps, and all the flies and beetles. On the other hand, many inseets do not show metamorphosis, but, like the birds, are hatehed from the egg in a condition plainly resembling the parents. A grasshopper (Fig. 42) is a conrenient example of an inseet without metamorphosis, or rather, as there are, after all, a few easily pereeived changes in its post-embryonie development, of an inseet with an "ineomplete metamorphosis." The oggs of grasshoppers are laid in little paekets of several seore half an ineh below the surface of the ground. When the young grasshopper hatehes from the egg it is of eourse very small, but it is plainly recognizable as a grasshopper. But in one important eharaeter it differs from the adult, and that is in its lak of wings. The adult grasshopper has two pairs of wings; the just hatehed young or larval grasshopper has no wings at all. The young grasshopper feeds voraciously and grows rapidly. 
In a few days it molts, or casts its outer skin (not the true skin, but a thin, firm covering or outer body wall composed of a substance called chitin, which is secreted by the cells of the true skin). In this second larval stage there can be seen the rudiments of four wings, in the condition
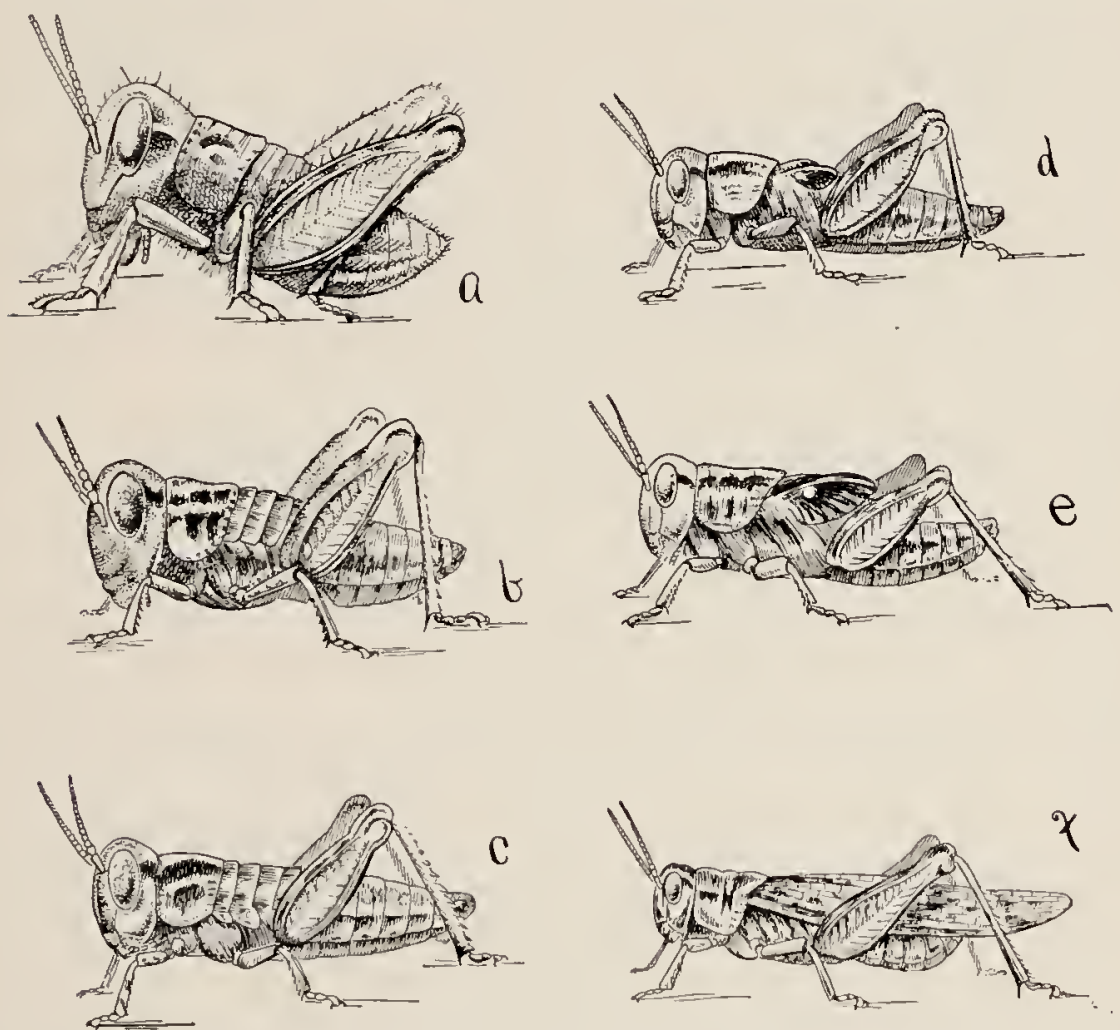

FIt. 42.-Post-embryonic development (incomplete metamorphosis) of the Rocky Mountain locust (Melanoplus spretus). $a, b, c, d, e$, and $f$, successive developmental stages from just hatched to adult individual.-After ЕмеRтоN.

of tiny wing pads on the back of the middle part of the body (the thorax). Soon the chitinous body covering is shed again, and after this molt the wing pads are markedly larger than before. Still another molt occurs, with another increase in size of the developing wings, and after a fifth and last molt the wings are fully developed, and 
the grasshopper is no longer in a larval or immature eondition, but is full grown and adult.

For example of eomplete metamorphosis among insects we may ehoose a butterfly, the large red-brown butterfly
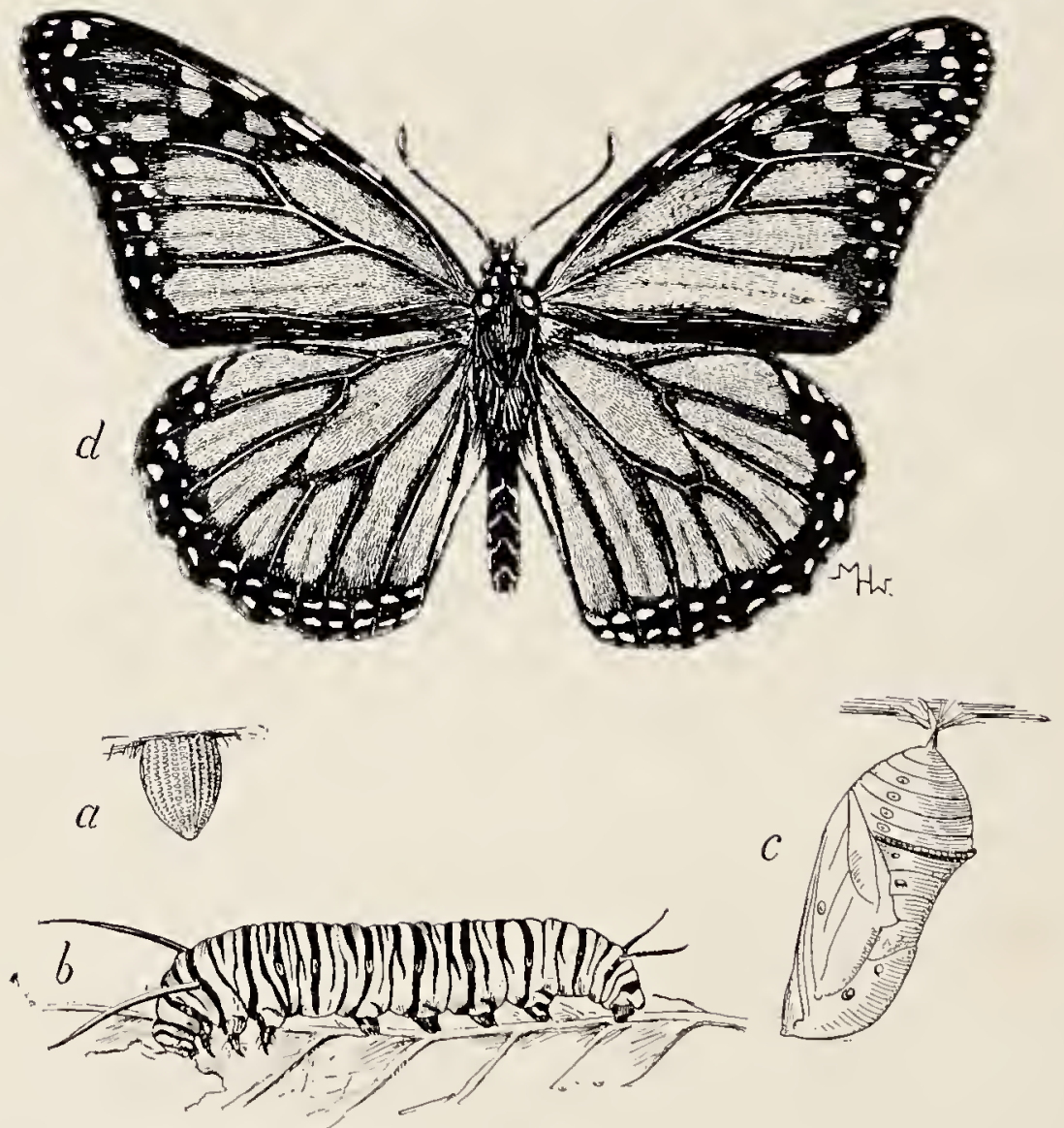

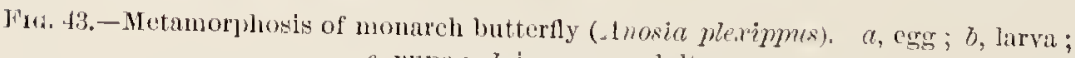
$c$, Iripu; $d$, imago or adult.

eommon in the United States and ealled the monarch or milkweed butterfly (Anosia plexipmms). The eggs (Fig. $43, a)$ of this butterfly are laid on the leaves of varions kinds of milkweed (Asclepias). The larval butterfly or butterfly larva or eaterpillar (as the first young stage of the butter- 
flies and moths is usually ealled), which hatches from the egg in three or four days, is a ereature bearing little or no resemblanee to the beautiful winged imago (the adult butterfly). It is worm-like, and instead of having three pairs of legs like the butterfly it has eight pairs; it has biting jaws in its mouth with which it nips off bits of the green milkweed leares, instead of having a long, slender, sucking proboscis for drinking flower neetar as the butterfly has. The body of the erawling worm.like larva (Fig. 43, b) is greenish yellow in color, with broad rings or bands of shining black. It has no wings, of course. It eats voraciously, grows rapidly and molts. But after the molting there is no appearance of rudimentary wings; it is simply a larger wormlike larva. It eontinues to feed and grow, molting several times, until after the fourth molt it appears no longer as an active, erawling, feed-

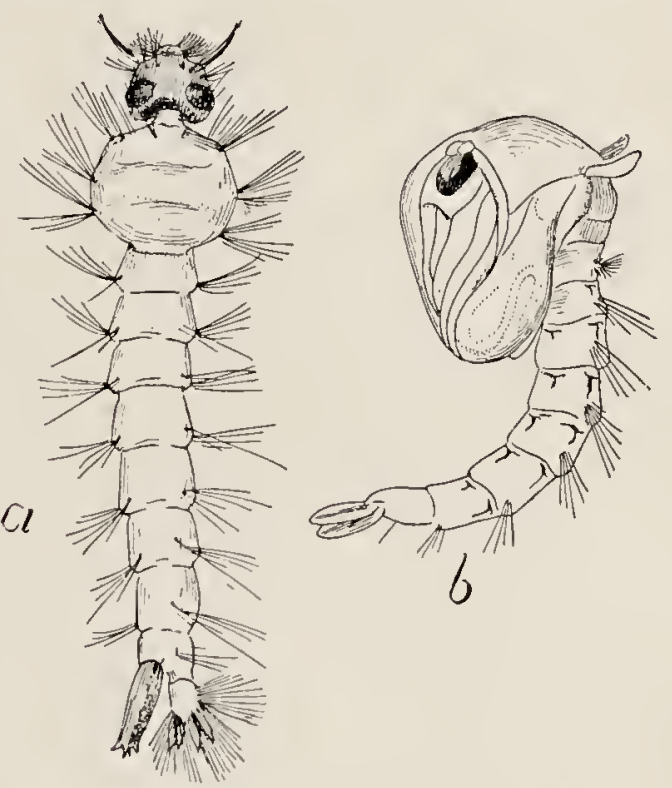

FIG. 44.-Mctamorphosis of mosquito (Culex). $a$, larva; $b$, pupa. ing, worm-like larva, but as a quieseent, non-feeding pupa or chrysalis (Fig. 43,c). The immature butterlly is now greatly contracted, and the onter ehitinous wall is very thick and firm. It is bright green in color with golden dots. It is fastened by one end to a leaf of the milkweed, where it hangs immovable for from a few days to two weeks. Finally, the chitin wall of the chrysalis splits, and there issues the full-fledged, great, four-winged, red-brown butterfly (Fig. $43, d$ ). Truly this is a metamorphosis, and a start- 
ling one. But we know that development in other animals is a gradual and continuous process, and so it is in the

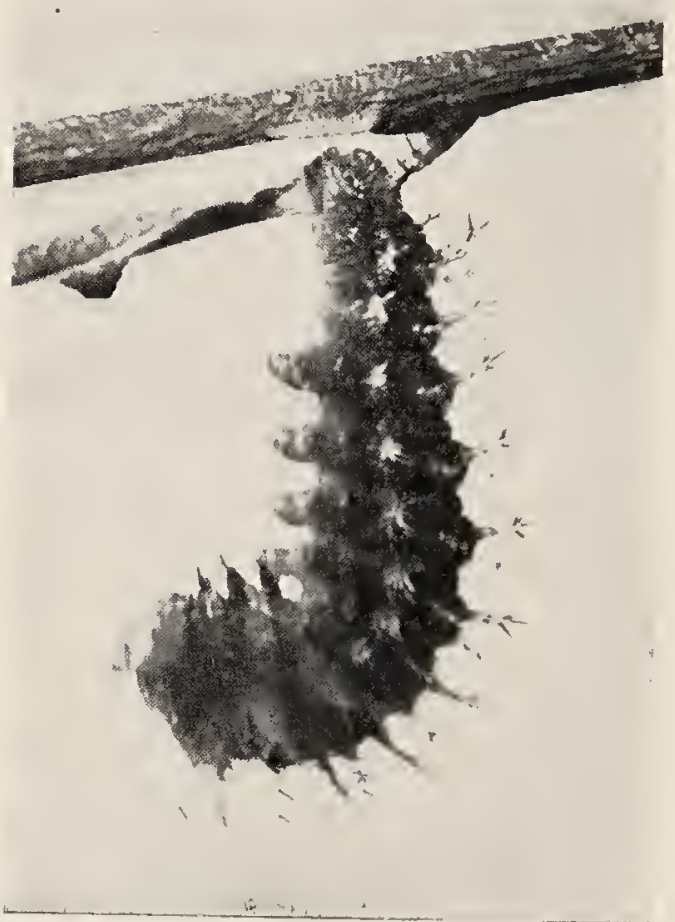

Frg. 45 - Larva of a butterlly just chmongr into pupa (making last larval molt). Photograph from Nature. case of the butterfly. The gradual changing is masked by the outer covering of the body in both larva and pupa. It is only at each molting or throwing off of this unchanging, myielding chitin armor that we perceive how far this change has gone. The longest time of concealment is that during the pupal or chrysalis stage, and the results of the changing or development when finally revealed by the splitting of the pupal case arc hence the most striking

58. Metamorphosis of the toad.-Metamorphosis is found in the development of numcrous other animals, as well as among the insects. Certain cases are familiar to all-the metamorphosis of the frogs and toads (Fig. 46). The eggs of the toud are arranged in long strings or ribbons in at transparent jelly-like substance. These jelly ribbons with the small, black, bead-like eggs in them are wound around the stems of submerged plants or sticks near the shores of the pond. From each egg hatches a tiny, wriggling tadpole, differing nearly as much from a full-grown toad as a catcrpillar differs from a butterfly. The tadpoles feed on 
the microscopic plants to be found in the water, and swim easily about by means of the long tail. The vcry young tadpoles remain underneath the surface of the water all the time, breathing the air which is mixed with water by means of gills. But as they become older and larger they comc often to the surface of the water. Lungs are developing inside the body, and the tadpole is beginning to brcathe as a land animal, although it still breathes partly by means of gills, that is, as an aquatic animal. Soon it is apparent that although the tadpole is steadily and rapidly growing larger, its tail is growing shorter and smaller instead of larger. At the same time, fore and hind legs bud out and rapidly take

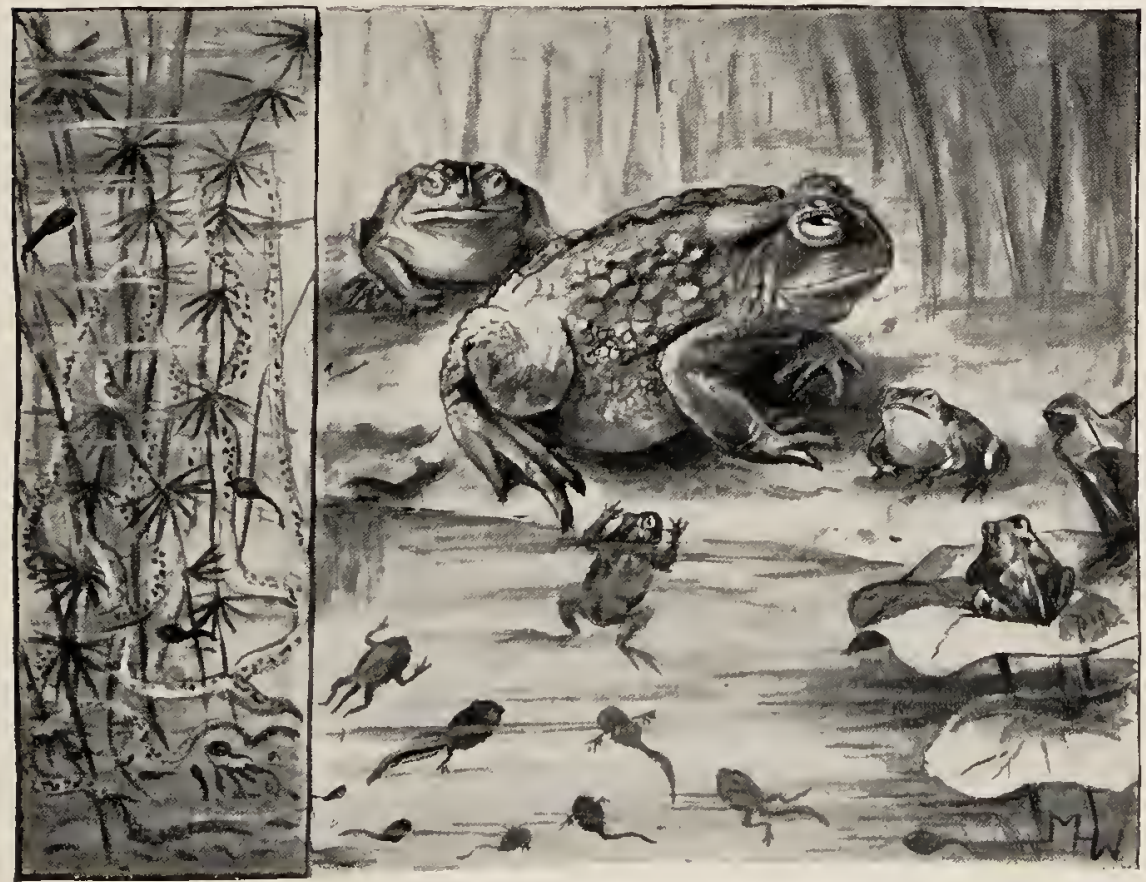

F1G. 46.-Metamorphosis of the toad (partly after GAGE). At left the strings of eggr, in water the various tadpole or larval stages, and on bink the adult toads.

form and become functional. By the time that the tail gets very short, indeed, the young toad is ready to leave the water and live as a land animal. On land the toad lives, as 
we know, on insects and snails and worms. The metamorphosis of the toad is not so striking as that of the butterfly, but if the tadpole were inclosed in an unchanging opaque body wall while it was losing its tail and getting its legs, and this wall were to be shed after these changes were made, would not the metamorphosis be nearly as cxtraordi-

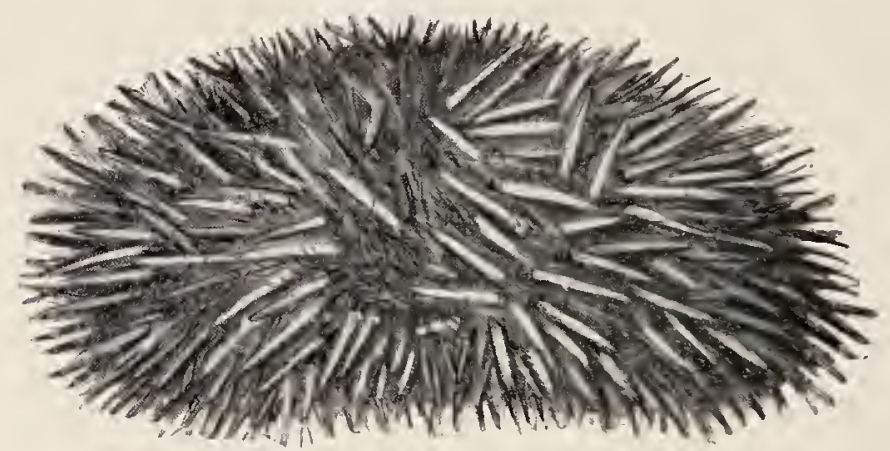

FIG. 4\%.-Metamorphosis of seaurchin. Upper figme the adult, lower figure the plutens larva.

nary as in the case of the butterfly? But in the metamorphosis of the toad we ean see the gradual and eontinuous character of the change.

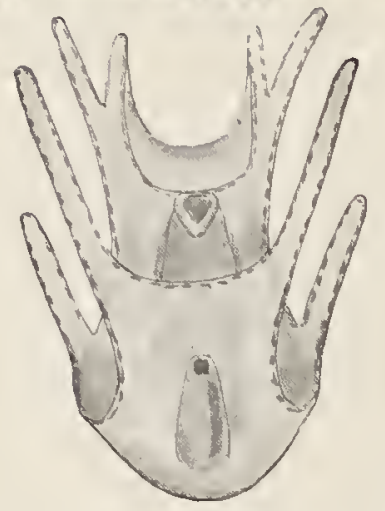

59. Metamorphosis among other animals-Many other animals, besides inseets and frogs and toads, undergo metamorphosis. The just-hatched sca-urchin does not resemble a fully developed sea-urehin at all. It is a minute wormlike creature, provided with cilia or vibratile hairs, by means of which it swims freely about. It ehanges next into a eurious bootjack-shaped body ealled the pluteus stage (Fig. 47). In the pluteus a skeleton of lime is formed, and the final true sea-urchin body begins to appoar inside the pluteus, 
developing and growing by using up the body substanee of the pluteus. Star-fishes, which are elosely related to seaurehins, show a similar metamolphosis, exeept that there is no plutens stage, the true star-fish-shaped body forming, within and at the expense of the first larval stage, the eiliated free-swimming stage.

A young erab just issued from the egg (Fig. 48) is a very different appearing ereature from the adult or fully developed erab. 'The body of the erab in its first larval stage is eomposed of a short, globular portion, fur-
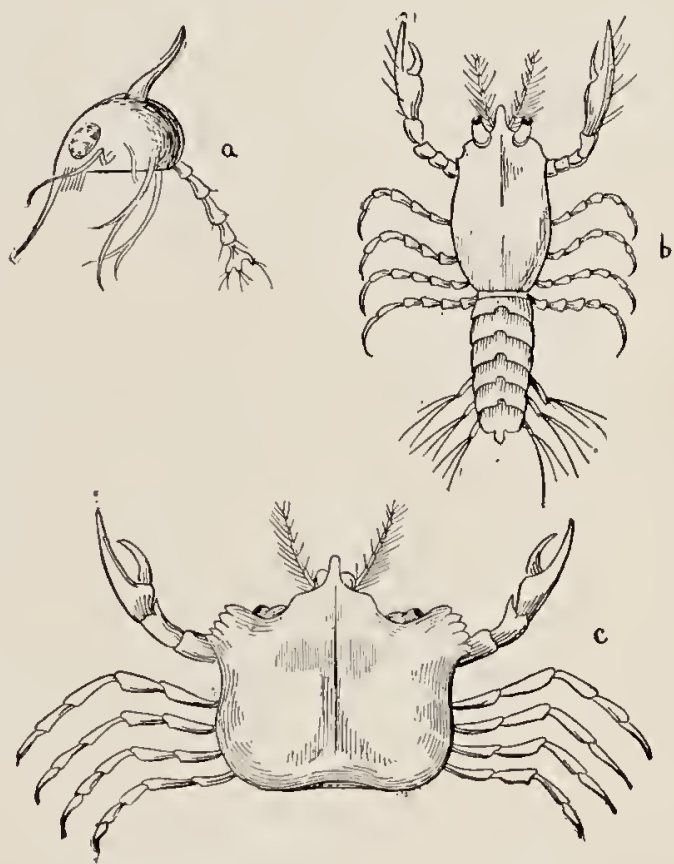

Fra. 48.-Metamorphosis of the crab. $a$, the zoena stage; $b$, the merralops; $c$, the adult. nished with eonspieuous long spines and a relatively long, jointed tail. This is ealled the zoëa stage. The zoïa ehanges into a stage ealled the megalops, whieh has many eharaeteristies of the adult erab condition, but differs espeeially from it in the possession of a long, segmented tail, and ili having the front half of the boly longer than wide. The erab in the megalops stage looks very much like a tiny lobster or shrimp. The tail soon disappears and the body widens, and the final stage is reached.

In many families of fishes the changes which take place in the eourse of the life eyele are almost as great as in the ease of the inseet or the toad. In the lady-fish (Albula vulpes) the very young (Fig. 49) are ribbon-like in form, 
with small heads and very loose texture of the tissues, the body substance being jelly-like and transparent. As the fish grows older the body becomes more compact, and therefore
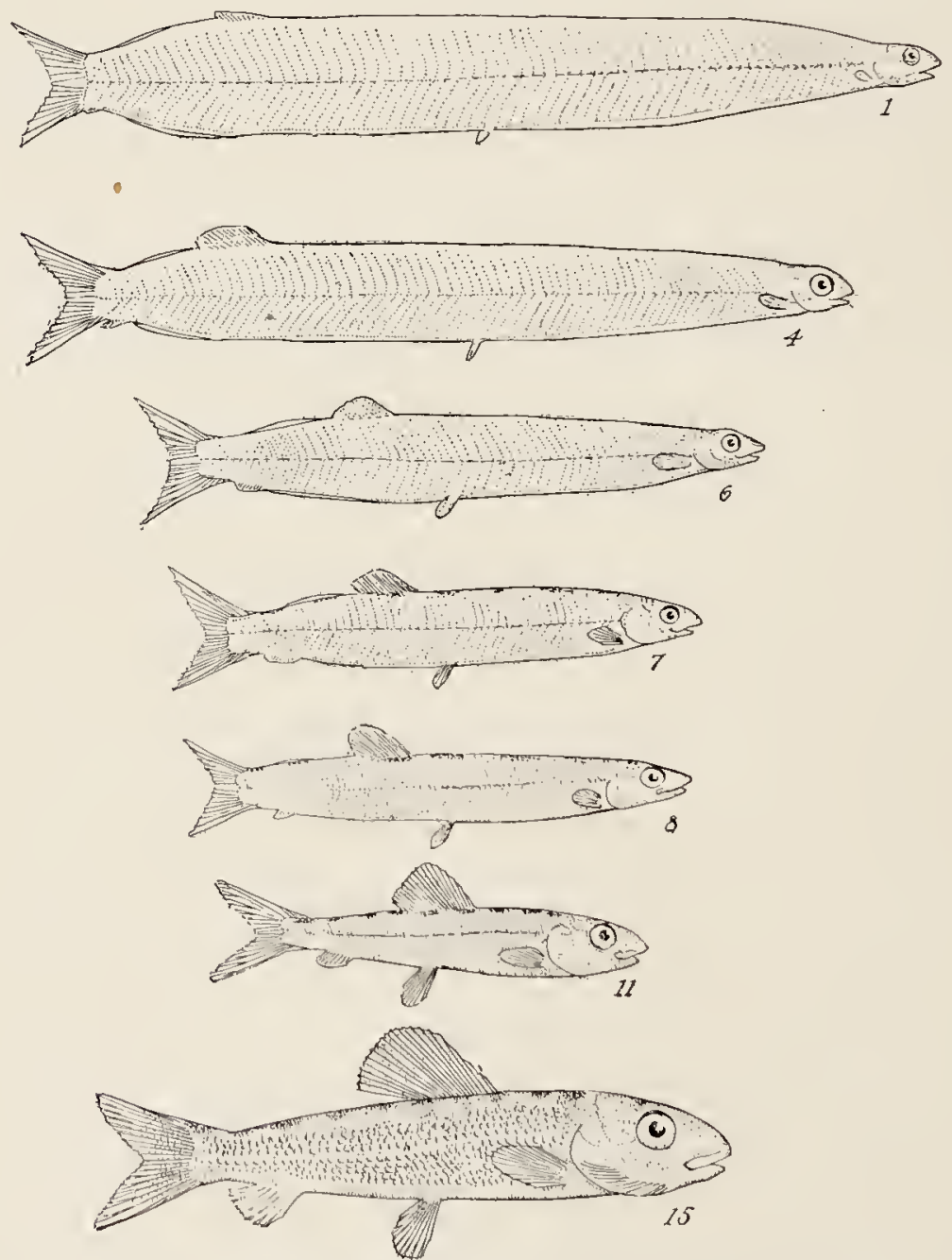

F1a.49.-Stages in the post-unbryonic development of the lady-fish (Albula vulpes), showing metamorphosis. -After C. II. GiLisert.

shorter and slimmer. After shrinking to the texture of an ordinary fish, its growth in size begins normally, although 
it has steadily inereased in aetual weight. Many herring, eels, and other soft-bodied fishes pass through stages similar to those seen in the lady-fish. Another type of development is illustrated in the sword-fish. The young has a bony head, bristling with spines. As it grows older the spines disappear, the skin grows smoother, and, finally, the bones of the upper jaw grow together, forming a prolonged sword, the teeth are lost and the fins become greatly modified. Fig. 50 shows three of these stages of growth. The
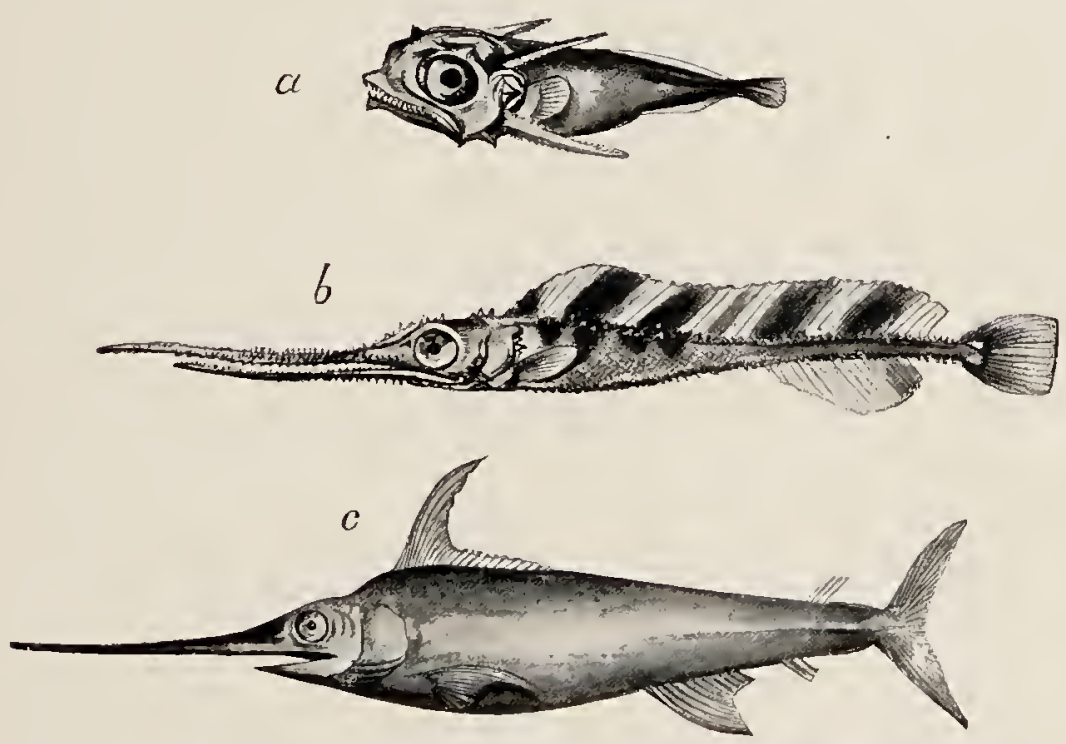

Fig. 50.-Three stages in the development of the sword-fish (. Tiphius gludius). $a$, very young; $b$, older; $c$, adult.-l'artly after LÜTKEN.

flounder or flat-fish (Fig. 51) when full grown lies flat on one side when swimming or when resting in the sand on the bottom of the sea. The eyes are both on the upper side of the body, and the lower side is blind and eolorless. When the flounder is hatehed it is a transparent fish, broad and flat, swimming vertieally in the water, with an eye on eaeh side. As its development (Fig. 5\%) goes on it rests itself obliquely on the bottom, the eye of the lower side turns upward, and as growth proceeds it passes gradually 
around the forehead, its soeket moving with it, until both eyes and sockets are transferred by twisting of the skull to

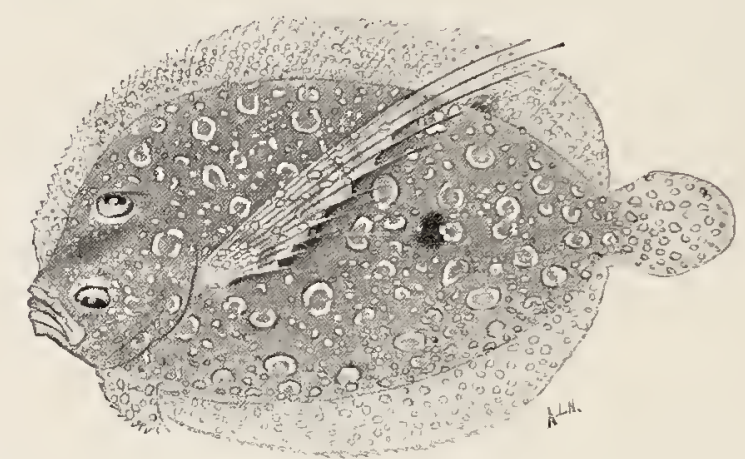

Fig. 51.-The wide-eyed flounder (Platophrys lunatus). Adnlt, showing both eyes on upper side of head.

the upper side. In some related forms or soles the small eye passes through the head and not around it, appearing finally in the same soeket with the other eye.

Thus in almost all the great groups of animals we find eertain kinds whiel show metamorphosis in their postembryonie development. But metamorphosis is simply development; its striking and extraordinary features are usmally due to the fact that the orderly, gradual eourse of the development is revealed to us only occasionally, with the result of giving the impression that the development is proeeeding by leaps and bounds from one strange stage to
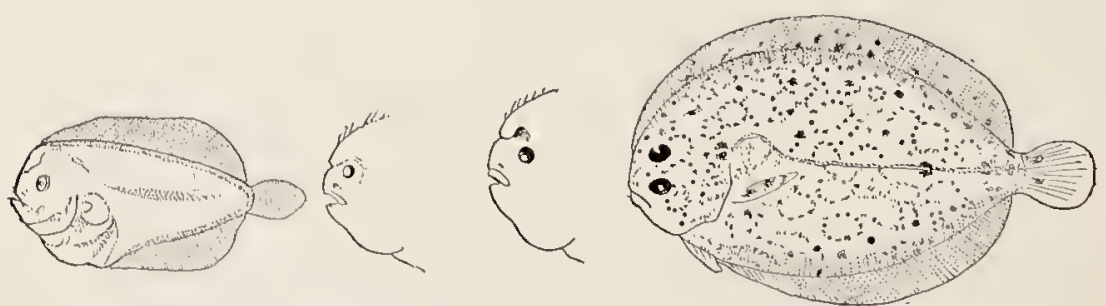

Fit. 52.-Development of a flounder (after EMERT). The eyes in the young flounder are arranged normally, one on eneh side of head.

another. If metanorphosis is carefully studied it loses its aspeet of marvel, although never its great interest. 
60. Duration of life.-After an animal has completed its development it has but one thing to do to complete its life cyele, and that is the production of offspring. When it has laid eggs or given birth to young, it has insured the beginning of a new life eyele. Does it now die? Is the business of its life aecomplished? There are many animals which die immediately or very soon after laying eggs. The May-flies-ephemeral insects which issue as winged adults from ponds or lakes in which they have spent from one to three years as aquatic crawling or swimming larva, flutter about for an evening, mate, drop their packets of fertilized eggs into the water, and die before the sunrise - are extreme examples of the numerous kinds of animals whose adult life lasts only long enough for mating and egglaying. But elephants live for two hundred years. Whales probably live longer. A horse lives about forty years, and so may a eat or toad. A sea-

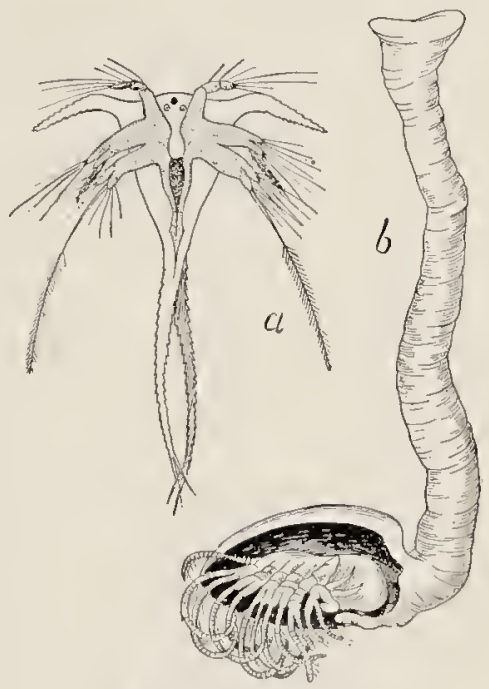

Fig. 53.-Metamorphosis of a bamacle (Lepus). a, larva; b, adult. anemone, which was kept in an aquarium, lived sixty-six years. Cray-fishes may live twenty years. A queen bee was kept in eaptivity for fifteen years. Most birds have long lives-the small song birds from eight to eighteen years, and the great eagles and vultures 11 p to a hundred years or more. On the other hand, among all the thonsands of species of insects, the individuals of very few indeed live more thim a year; the adult life of most insects being but a few days or weeks, or at best months. Even among the higher animals, some are very short-lived. In Japan is a small fish (Soleux) which probably lives 
but a year, ascending the rivers in numbers when young in the spring, the whole mass of individuals dying in the fall after spawning.

Naturalists have sought to discover the reason for these extraordinary differences in the duration of life of different animals, and while it can not be said that the reason or reasons are wholly known, yet the probability is strong that the duration of life is closely connected with, or dependent upon, the conditions attending the production of offspring. It is not sufficient, as we have learned from our study of the multiplication of animals (Chapter III), that an adult animal shall produce simply a single new individual of its kind, or even only a few. It must produce many, or if it produces comparatively few it must derote great care to the rearing of these few, if the perpetuation of the species is to be insured. Now, almost all long-lived animals are species which produce but few offspring at a time, and reproduce only at long intervals, while most short-lived animals produce a great many eggs, and these all at one time. Birds are long-lived animals; as we know, most of them lay eggs but once a year, and lay only a few eggs each time. Many of the sea birds which swarm in countless numbers on the rocky ocean islets and great sea cliffs lay only a single egg once each year. And these birds, the guillemots and murres and anks, are especially long-lived. Insects, on the contrary, usually prodnce many eggs, and all of them in a short time. The May-fly, with its one evening's lifetime, lets fall from its body two packets of eggs and then dies. 'Thus the shortening of the period of reproduction with the production of a great many offspring seem to be always associated with a short alult lifetime; while a long period of reproduction with the production of few offspring at a time and care of the offspring are associated with a long adult lifetime.

There seems also to be some relation between the size of animals and the length of lifo. As a general rule, 
large animals are long-lived and small animals have short lives.

61. Death.-At the end comes death. After the animal has completed its life cycle, after it has done its share toward insuring the perpetuation of its species, it dies. It may meet a violent death, may be killed by accident or by enemies, before the life cycle is completed. And this is the fate of the vast majority of animals which are born or hatched. Or death may come before the time for birth or hatching. Of the millions of eggs laid by a fish, each egg a new fish in simplest stage of development, how many or rather how few come to maturity, how few complete the cycle of life!

Of death we know the essential meaning. Life ceases and can never be renewed in the body of the dead animal. It is important that we include the words "can never be renewed," for to say simply that "life ceases," that is, that the performance of the life processes or functions ceases, is not really death. It is easy to distinguish in most cases between life and death, between a live animal and a dead one, yet there are cases of apparent death or a semblance of death which are very puzzling. The test of life is usually taken to be the performance of life functions, the assimilation of food and excretion of waste, the breathing in of oxygen, and breathing out of carbonic-acid gas, morement, feeling, etc. But some animals can actually suspend all of these functions, or at least reduce them to such a minimum that they can not be perceived by the strictest examination, and yet not be dead. 'That is, they can renew again the performance of the life processes. Bears and some other animals, among them many insects, spend the winter in a state of death-like sleep. Perhaps it is but slecp; and yet hibernating insects can be frozen solid and remain frozen for wceks and months, and still retain the power of actively living again in the following spring. Even more remarkable is the case of certain minute animals called $R_{0-}$ 
tatoria and of others called Tardigrada, or bear-animalcules. These bear-animalcules live in water. If the water dries up, the animaleules dry up too; they shrivel up into formless little nuasses and become completely desiccated. They are simply dried-up bits of organic matter, they are organic dust. Now, if after a long time-years even-one of these organic dust particles, one of these dried-up bear-animalcules is put into water, a strange thing liappens. The body swells and stretches out, the skin bccomes smooth instead of all wiinkled and folded, and the legs appear in normal shape. The body is again as it was years before, and after a quarter of an hour to several hours (depending on the length of time the animal has lain dormant and dried) slow movements of the body parts begin, and soon the animaleule crawls about, begins again its life where it had been interrupted. Tarious other small animals; such as vinegar eels and certam Protozoa, show similar powers. Certainly here is an interesting problem in life and death.

When deatl comes to one of the animals with which we arc familiar, we are accustomed to think of its eoming to the whole body at some exact montent of time. As we stand beside a pet which has been fatally injured, we wait until suddenly we say, "It is deal." As a matter of fact, it is diflicult to say when death ocenrs. Long after the heart eeases to beat, other organs of the body are alivethat is, are able to perform their special functions. The muscles cam contract for minutes or lours (for" a short time in warm-blooded, for a long time in cold-blooded animals) after the animal ecases to breathe and its heart to beat. Even longer live certain cells of the body, especially the amwboid white blood-corpuscles. These cells, very like the Amola in eharacter, live for days after the animal is, as we say, dead. The cells which line the tracheal tubc lcading to the lungs bear cilia or fine hairs which they wave back and forth. They continue this movement for days after the heart lias ceased beating. Among cold- 
blooded animals, like snakes and turtles, complete cessation of life functions comes very slowly, even after the body has beell literally cut to picces.

Thus it is essential in defining death to speak of a complete and permanent cessation of the pcrformance of the life processes.

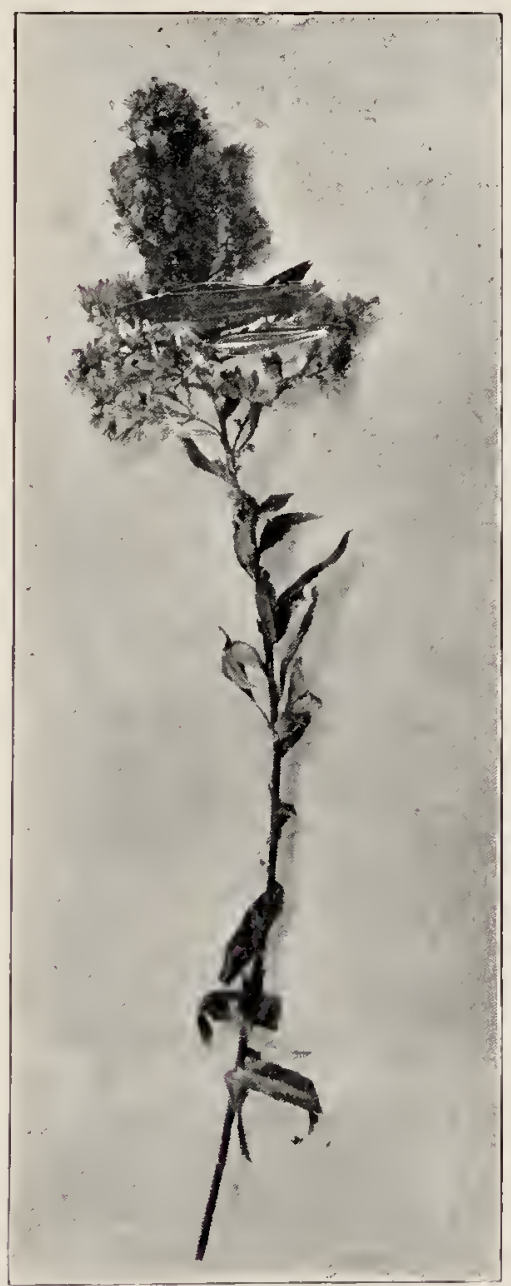

A grasshopper (Melunoplus differenfielis) killed by disease cunsed by a parasitic fungrus. On golden-rod. 


\section{CHAPTER VI}

\section{THE PRIMARY CONDITIONB OF ANIMAL LIFE}

\section{Primary conditions and special conditions-Certain}

primary conditions are necessary for the existence of all animals. We know that fishes can not live rery long out of water, and that birds can not live in water. These, howerer, are special conditions which depend on the speeial structure and habits of these two partieular kinds of backboned animals. But the neeessity of a constant and sufficient supply of air is a neeessity common to both; it is one of the primary conditions of their life. All animals must have air. Similarly both fishes and birds, and all other animals as well, must have food. 'This is another one of the primary conditions of animal life. That backboned animals must find somehow a supply of salts or compounds of lime to form into bones is a special eondition peculiar to these animals. Other animals having shells or teeth composed of anbonate or phosphate of lime are subjeet to the same special demand, but many animals have no hard parts, and therefore need no lime.

63. Food--All the higher plants, those that are green (chlorophyll-bearing), ean make their living substance out of inorganic matter alone-that is, use morganic substances as food. But animals ean not do this. They must have alrealy formed organie matter for food. This organic matter llaty be the living or dead tissues of plants, or the living or dead tissues of animals. For the life of animals it is neeessary that other organisms live, or have lived. It is this need which primarily distinguishes an animal from a 
plant. Animals ean not exist without plants. The plants furnish all animals with food, either directly or indirectly. The amount of food and the kinds of food required by various kinds of animals are special conditions depending on the size, the degree of activity, the struetural charaeter of the body, etc., of the animal in question. Those whieh do the most need most. Those with warmest blood, greatest aetivity, and most rapid ehange of tissues are most dependent on abundance, regularity, and fitness of their food. As we well know, an animal can live for a longer or shorter time without food. Men have fasted for a month, or even two months. Among eold-blooded animals, like the reptiles, the general habit of food taking is that of an occasional gorging, succeeded by a long period of abstinenee. Many of the lower animals can go without food for surprisingly long periods without loss of life. But the continued lack of food results incvitably in death. Any animal may be starved in time.

If water be held not to be included in the gencral eoneeption of food, then special mention must be made of the neccssity of water as one of the primary eonditions of animal life. Protoplasm, the basis of life, is a fluid, although thiek and viscons. To be fluid its eomponents must be dissolved or suspended in water. In faet, all the truly living substanee in an animal's body eontains water. The hard parts, as bones and teeth and nails, are not really living. The water neeessary for the animal may be derived from the other food, all of whieh contains water in greater or less quantity, or may be taken apart from the other food, by drinking or by absorption through the skin. Sheep are seldom scen to drink, for they find almost enongh water in their green food. Fur scals never drink, for they absorb the water needed through pores in the skin.

64. 0xygen.-Animals must have air in order to live, but the essential clement of the air which they need is its oxygen. For the metabolism of the body, for the chemical 
ehanges which take place in the body of every living animal, a supply of oxygen is required. This oxygen is derived directly or indirectly from the air. The atmosphere of the earth is eomposed of 79.02 parts of nitrogen (ineluding argon), .03 parts of carbonie aeid, and 20.95 parts of oxygen. Thus all the animals which live on land are enveloped by a substance containing nearly 21 per eent of oxygen. But animals can live in an atmosphere containing much less oxygen. Certain mammals, experimented on, lived without diffieulty in an atmosphere eontaining only 14 per cent of oxygen; when the oxygen was reduced to $\%$ per cent serious disturbances were eaused in the animal's eondition, and death by suffocation ensued when 3 per eent of oxygen was left in the atmosphere. Animals which live in water get their oxygen, not from the water itself (water being composed of hydrogen and oxygen), but from air which is meehanically mixed with the water. Fishes breathe the air whieh is mixed with or dissolved in the water. This seanty supply therefore eonstitutes their atmosphere, for in water from which all air is excluded no animal can breathe. Whatever the habits of life of the animal, whether it lives on the land, in the ground, or in the water, it must have oxygen or die.

65. Temperature, pressure, and other conditions.-Some physiologists inelude among the printary or essential general conditions of animal life such eonditions as favorable temperature and favorable pressure. It is known from observation and experiment that animals die when a too low or a too high temperature prevails. 'The minimum or maximum of temperature between which limits an animal ean live varies mueh among different kinds of animals. It is familiar knowledge that many kinds of animals ean be frozen and yet not be killed. lnseets and other small animals may lie frozen through a winter and resume active life again in the spring. An experimenter kept eertain fish frozen in bloeks of ice at a temperature of $-15^{\circ} \mathrm{C}$. 
for some time and then gradually thawed them out unhurt. Only very hardy kinds adapted to the cold would, however, survive such treatment. There is no doubt that every part of the body, all of the living substance, of these fish was frozen, for specimens at this temperature could be broken and pounded up into fine ice powder. But a temperature of $-20^{\circ} \mathrm{C}$. killed the fish. Frogs lived after being kept at a temperature of $-28^{\circ} \mathrm{C}$, centipeds at $-50^{\circ} \mathrm{C}$, and certain snails endured a temperature of $-120^{\circ} \mathrm{C}$. without dying. At the other extreme, instances are known of animals living in water (hot springs or water gradually heated with the organisms in it) of a temperature as high as $50^{\circ} \mathrm{C}$. Experiments with Amoebce show that these simplest animals contract and cease active motion at $35^{\circ} \mathrm{C}$, but are not killed until a temperature of $40^{\circ}$ to $45^{\circ} \mathrm{C}$. is reached. The little fish called blob or miller's thumb (Cottus ictalops) has been scen lying boiled in the bottom of the hot springs in the Yellowstone Park; but it must have entered these springs through streams of a temperature little below the boiling point.

The pressure or weight of the atmosphere on the surface of the carth is nearly fiftcen pounds on each square inch. This pressure is exerted equally in all directions, so that an object on the earth's surface sustains a pressure on each square inch of its surface exposed to the air of fiftcen pounds. Thus all animals living on the earth's surface or near it live under this pressure, and know no other condition. For this reason they do not notice it. The animals which live in water, however, sustain a much greater pressure, this pressure increasing with the depth. Ccrtain ocean fishes live habitually at great depths, as two to five miles, where the pressure is equivalent to that of many hundred atmospheres. If these fishes are brought to the surface their eycs bulge out fearfully, bcing pushed out through reduced expansion; their scales fall off becaluse of the great expansion of the skin, and the stomach is pushed 
out from the mouth till it is wrong side out. Indeed, the bodies sometimes burst. 'Their bodies are accustomed to this great pressure, and when this outside pressure is suddenly removed the body may be bursted. Sometimes such a fish is raised from its proper level by a struggle with its prey, when both captor and vietim may be destroyed by the expansion of the body. Sonie fishes die on being taken out of water through the swelling of the air bladder and the bursting of its blood-ressels. If an animal which lives normally on the surface of the earth is taken up a very high mountain or is earried up in a balloon to a great altitude where the pressure of the atmosphere is mueh less than it is at the earth's surface, serious consequences may ensue, and if too high an altitude is reached death occurs. This death may be in part duc to the difficulty in breathing in sufficient oxygen to maintain life, but it is probably chiefly due to disturbances caused by the removal of the pressure to which the body is aeenstomed and is strueturally adapted to withstand. A famous balloon ascension was made in Paris in $18 \% 5$ by three men. After the balloon had reached a height of nearly 24,000 feet (almost five miles) the men began to lose conseiousness. On the sinking of the balloon to about 20,000 fect the men regained conseiousncss again and threw ont ballast so that the balloon rose to a height of over 25,000 feet. This time all three becane wholly mnconseious, and on the balloon sinking again only one regained consciousness. The other two died in the foolhardy experiment. All living animals are aceustomed to live under a certain pressure, and there are evidently limits of maximum or minimum pressure beyond which no animal at present existing can go and remain alive.

But in the case both of temperature and pressure conditions it is easy to conceive that animals m. oxht exist which could live moler temperature and pressure onditions not included between the minimum and maximum vits of each 
as determined by animals so cxisting. But it is impossible to conceive of animals which could live without oxygen or without organic food. The necessities of oxygen and organic food (and water) are the primary or essential conditions for the existence of any animals.

Of course, we might include such conditions, among the primary conditions, as the light and heat of the sun, the action of gravitation, and other physical conditions without which existence or life of any kind would be impossible on this earth. But we here consider by "primary conditions of animal life" rather those necessities of living animals as opposed to the neccssities of living plants. Neither animals nor plants could exist without the sun, whence they derive directly or indirectly all their encrgy.

66. Difference between animals and plants.-It is easy to distinguish between the animal and plant when a butterfly is fluttering about a blossoming cherry trce or a cow feeding in a field of clover. It is not so easy, if it is, indecd, possible, to say which is plant and which is animal when the simplest plants arc compared with the simplest animals. It is almost impossible to so define animals as to distinguish all of them from all plants, or so to define plants as to distinguish all of them from all animals. While most animals have the power of locomotion, some, like the sponges and polyps and barnacles and numerous parasites, are fixed. While most plants are fixed, some of the low aquatic forms have the power of spontaneous locomotion, and all plants have some power of motion, as especially excmplified in the revolution of the apex of the growing stem and root, and the spiral twisting of tendrils, and in the sudden closing of the lcaves of the scnsitive plant when touched. Among the grcen or chlorophyllbearing plants the food consists chiefly of inorganic substances, especially of carbon which is taken from the carbonic-acid gas in the atmosphere, and of water. But some green-leared plants feed also in part on organic food. 
Such are the pitcher-plants and sun-dews, and Venus-flytraps, which catch insects and use them for food nutrition. But there are many plants, the fungi, which are not green -that is, which do not possess chlorophyll, the substance on which secms to depend the power to make organic matter out of inorganic substances. These plants fecd on organic matter as animals do. The cells of plants (in their young stages, at least) have a wall composed of a peculiar carbohydrate substance called cellulose, and this cellulose was for a long time believed not to occur in the body of animals. But now it is known that certain sea-squirts (Tunicata) possess cellulose. It is impossible to find any set of characteristics, or even any one characteristic, which is possessed only by plants or only by animals. But noarly all of the many-celled plants and animals may be casily distinguished by their gencral characteristics. The power of brcaking up carbonic-acid gas into carbon and oxygen and assimilating the carbon thus obtained, the presence of chlorophyll, and the cell walls formed of cellulose, are characteristics constant in all typical plints. In addition, the fixed life of plants, and their general use of inorganic substances for food instead of organic, arc characteristics readily observed and practically characteristic of many. celled plants. When the thousands of kinds of one-celled orgunisms are compared, howcrer, it is often a matter of great difficulty or of real impossibility to say whether a given organism shonld be assigned to the plant kingdom or to the animal kingdom. In general the distinctive characters of plants are grouped around the loss of the power of locomotion and related to or dependent upon it.

$6 \%$ Living organic matter and inorganic matter.-It wonld seem to be an casy matter to distinguish an organism-that is, a living aninal or plant-from an inorganic substance. It is easy to distinguish a dove or a sunflower from stone, and practically there never is any difficulty in making such distinctions. But when we try to define living organic matter, 
and to deseribe those eharaeteristics which are peculiar to it, which absolutcly distinguish it from inorganie matter, we meet with some difficulties. At least many of the charaeteristies commonly aseribed to organisms, as peeuliar to them, are not so. The possession of organs, or the eomposition of the body of distinet parts, each with a distinet funetion, but all working together, and depending on each other, is as true of a steam-engine as of a horse. That the work done by the steam-engine depends upon fuel is true; but so it is that the work done by the horse depends upon fuel, or food as we eall it in the case of the animal. The oxidation or burning of this fuel in the engine is wholly eomparable with the oxidation of the food, or the musele and fat it is turned into, in the horse's body. The composition of the bodies of animals and plants of tiny structural units, the cells, is in many ways comparable with the eomposition of some roeks of tiny structural units, the crystals. But not to earry such rather quibbling eomparisons too far, it may be said that organisms are distinguished from organic substanees by the following charaeteristies: Organization; the power to make over inorganie substances into organie matter, or the changing of organic matter of one kind, as plant matter, into another kind, as animal matter; motion, the power of spontaneous movement in response to stimuli; sensation, the power of being sensible of external stimuli; reproduction, the power of producing new bcings like themselves; and adaptation, the power of responding to external conditions in a way uscful to the organism. 'Through adaptation organisins continue to exist despite the ehanging of eonditions. If the eonditions surrounding an inorganie body ehange, even gradually, the inorganie body does not change to adapt itself to these eonditions, but resists then until no longer able to do so, when it loses its identity or integrity. 


\section{CHAPTER VII}

\section{THE CROWD OF ANIMALS AND THE STRUGGLE FOR EXISTENCE}

68. The crowd of animals.-All animals feed upon living organisms, or on their dead bodies. Hence each animai throughout its life is busy with the destruetion of other organisms, or with their removal after death. If those creatures upon which others feed are to hold their own, there must be enough born or developed to make good the drain upon their numbers. If the plants did not fill up their ranks and make good their losses, the animals that feed on them would perish. If the plant-eating animals were destroyed, the flesh-eating animals would in turn disappear. But, fortmnately, there is a rast excess in the process of reproduction. More plants sprout than ean find room to grow. More animals are born than can possibly survive. The process of increase anlong animils is correctly spoken of as multiplication. Each species tends to inerease in geometrio ratio, but as it multiplies its nembers it finds the world already erowded with other species doing the same thing. $\Lambda$ single pair of any species whatsoerer, if not restrained by adverse comtitions, rould soon increase to such an extent as to fill the whole world with its progeny. An annual plant produeing two seeds only would have $1,048,5 \% 6$ descendants at the end of trenty-one years, if ench seed spronted and matured. The ratio of increase is therefore a matter of minor importanee. It is the ratio of net increase above loss which determines the fate of a spoeies. Those speeies inerease in numbers whose gain exceeds 
the death rate, and those which "live beyond their means" must sooner or later disappear. One of the most abundant of birds is the fulmar petrel, which lays but one egg yearly. It has but few enemies, and this low rate of increase suffices to cover the seas within its range with petrels.

It is difficult to realize the inordinate numbers in which each species would exist were it not for the checks produced by the presence of other animals. Certain Protozoa at their normal rate of increase, if none wcre devoured or destroyed, might fill the entire ocean in about a week. The congereel lays, it is said, 15,000,000 eggs. If each egg grew up to maturity and reproduced itself in the sanc way in less than ten years the sea would be solidly full of congereels. If the eggs of a common house-fly should develop, and each of its progeny should find the food and temperature it needed, with no loss and no destruction, the people of a city in which this inight happen could not get away soon enough to escape suffocation from a plague of flies. Whenever any insect is able to develop a large percentage of the eggs laid, it becomes at once a plague. Thus originate plagues of grasshoppers, locusts, and caterpillars. But the crowd of life is such that no great danger exists. The scavenger destroys the decaying flesh where the fly would lay its eggs. Minute creatures, insects, bacteria, Protozoa are parasitic within the larva and kill it. Millions of flies perish for want of food. Millions more are destroyed by insectivorous birds, and millions are slain by parasites. The final resnlt is that from year to year the number of flies does not increase. Linnæus once said that "three flies would devour a dead horse as quickly as a lion." Equally soon would it be devoured by three bacteria, for the decay of the liorse is due to the decomposition of its flesh by these microscopic plants which feed upon it. "Even slow-brceding man," says Darwin, "has loubled in twenty-five years. At this rate in less than a thousand years there would literally not be standing room for his progeny. The elephant is reckoned the slow- 
est breeder of all known animals. It begins breeding when thirty years old and goes on breeding until ninety years old, bringing forth six young in the interval, and surviving till a humdred years old. If this be so, after about eight hundred years there would be 19,000,000 elephants alive, deseended from the first pair." A few years more of the unchecked multiplieation of the elephant and every foot of land on the earth would be eovered by them.

Yet the number of elephants does not inerease. In general, the numbers of every species of animal in the state of Nature remain about stationary. Under the influenee of man most of them slowly diminish. There are about as many squirrels in the forest one year as another, abont as many butterflies in the field, about as many frogs in the pond. Wolves, bears, deer, wild dueks, singing birds, fishes, tend to grow fewer and fewer in inhabited regions, beeause the losses from the hand of man are added to the losses in the state of Nature.

It has been shown that at the normal rate in inerease of English sparrows, if none were to die save of old age, it would take but twenty years to give one sparrow to every square inch in the State of Indima. Sueh an inerease is aetually impossible, for more than a hundred other speeies of similar birds are disputing the same territory with the power of inerease at a similar rate. There ean not be food and spaee for all. With sueh eonditions a struggle is set up between sparrow and sparrow, between sparrow and other birds, and between sparrow and the eonditions of life. Such a eonfliet is known as the struggle for existenee.

69. The struggle for existence,-The struggle for existenee is threefold: ( $($ ) among individuals of one speeies, as sparrow and sparrow; $(b)$ between individuals of different species, as sparrow with bluebird or robin; and (c) with the conditions of life, as the effort of the sparrow to keep warm in winter and to find water in summer. All three forms of this struggle are constantly operative and with 
every species. In some regions the one phase may be more destructive, in others another. Where the conditions of life are most easy, as in the tropics, the struggle of species with species, of individual with individual, is the most severe.

No living being can escape from any of these three phases of the struggle for existence. For rcasons which we shall see later, it is not well that any should escape, for " the sheltered life," the life withdrawn from the stress of effort, brings the tendency to degeneration.

Bccause of the destruction resulting from the struggle for existence, more of every species are born than can possibly find space or food to mature. The majority fail to reach their full growth bccausc, for one reason or another, they can not do so. All live who can. Each strives to feed itsclf, to save its own life, to protect its young. But with all their efforts only a portion of each species succeed.

70. Selection by Nature.-But the destruction in Nature is not indiscriminate. In the long run those lcast fitted to resist attack are the first to perish. It is the slowest animal which is soonest overtaken by those which fced upon it. It is the weakest which is crowded away from the feeding-place by its associates. It is the lcast adapted which is first destroyed by cxtremes of heat and cold. Just as a farmer improves his herd of cattle by destroying his weakest or roughest calves, reserving the strong and fit for parentage, so, on an inconceivably large scale, the forces of Nature are at work purifying, strengthening, and fitting to their surroundings the various species of animals. 'This process has been called natural selection, or the survival of the fittest. But by fittest in this sense we mean only best adapted to the surroundings, for this process, like others in Nature, has itself no ncccssarily moral clement. The songbird becomes through this process more fit for the song-bird life, the hawk bccomes more capable of killing and tear- 
ing, and the woodpeeker better fitted to extraet grubs from the tree.

In the struggle of species with speeies one may gain a little one year and another the next, the numbers of each speeies fluctuating a little with varying circumstances, but after a time, unless disturbed by the hand of man, a point will be reached when the loss will almost exactly balance the inerease. This produces a eondition of apparent equilibrium. The equilibrium is broken when any individual or group of individuals beeomes eapable of doing something more than hold its own in the struggle for existence.

When the conditions of life beeome adverse to the existence of a species it has three alternatives, or, better, one of three things happens, namely, migration, adaptation, extinetion. The migration of birds and some other animals is a systematic changing of enviromment when conditions are unfavorable to life. When the snow and iee come, the furseal forsakes the islands on which it breeds, and which are its real home, and spends the rest of the year in the open sea, retmrning at the elose of winter. Some other animals migrate irregularly, removing from place to place as eonditions become severe or undesirable. The Roeky Mountan locusts, which breed on the great platean along the eastern base of the Rochy Mountains, sometimes increase so rapidly in numbers that they can not find enough food in the scanty vegetation of this region. Then great hosts of them fly high into the air until they meet an air eurrent moving toward the southeast. The loensts are borne by this eurrent or wind hundreds of miles, until, when they come to the great granin-growing Mississippi Valley, they deseend and feod to their hearts' content, and to the dismay of the Nebraska and Kansas farmer. 'These great forced migrations used to oceur only too often, but none has taken place sinee 18\%8, and it is probable that none will ever oceur again. With the settlement of the Rocky Mountain plateau by farmers, food is plenty at home. And the constant fight- 
ing of the locusts by the farmers, by plowing up their eggs, and crushing and burning the young hoppers, keeps down their numbers.

Another animal of interesting migratory habits is the lemming, a mouse-like animal nearly as large as a rat, which lives in the arctic regions. At intervals varying from five to twenty years the cultivated lands of Norway and Sweden, where the lemming is ordinarily unknown, are ovcrum by vast numbers of these little animals. They come as an army, steadily and slowly advancing, always in the same direction, and "regardless of all obstacles, swimming across streams and even lakes of several miles in breadth, and committing considerable devastation on their line of march by the quantity of food they consume. In thcir turn they are pursued and harassed by crowds of beasts and birds of prey, as bears, wolves, foxes, dogs, wild cats, stoats, weasels, cagles, hawks, and owls, and never spared by man; even the domestic animals not usually predaceous, as cattle, foals, and reindeer, are said to join in the destruction, stamping them to the ground with their feet and even eating their bodies. Numbers also die from diseasc apparently produced from overcrowding. None ever return by the course by which they came, and the onward march of the survivors never ccascs until they reach the sea, into which they plunge, and swimming onward in the samc direction as before perish in the waves." One of these great migrations lasts for from one to three years. But it always ends in the total destruction of the migrating army. But the inigration may be of advantage to the lemmings which remain in the original breeding grounds, leaving them with cnough food, so that, on the whole, the migration results in gain to the species.

But most animals can not migrate to their betterment. In that case the only alternatives are adaptation or destruction. Somc individuals by the possession of slight advantageous variations of structure are able to meet the new 
demands and survive, the rest die. The survicors ploduce young similarly advantageously different from the general type, and the adaptation inereases with successive generations.

\section{Adjustment to surroundings a result of natural selec-} tion.-To such canses as these we must aseribe the nice adjustment of each species to its surroundings. If a species or a group of individuals can not adapt itself to its enrironment, it will be erowded out by others that can do so. The former will disappear entirely from the earth, or else will be limited to surroundings with which it eomes into perfect adjustment. A partial adjustment must with time become a complete one, for the individuals not adapted will be exterminated in the struggle for life. In this regard very small variations may lead to great results. A side issue apparently of little consequenee may determine the fate of a speeies. Any adrantage, no matter how small, will turn the seale of life in favor of its possessor and his progeny. "Battle within battle," says a famous naturalist, "must be continually recuring, with rarying suceess. Yet in the long run the forees are so nieely balaneed that the face of Nature remains for a long time uniform, though assuredly the merest trifle would give the vietory to one organie being over another."

\%\%. Artificial selection.-It has been long known that the nature of a herd or riee of animals can be materially altered by a eonscious selection on the part of man of these individuals whieh are to beeome parents. To "weed out" a herd artificially is to improve its blood. To seleet for reproluetion the swiftest horses, the best milk cows, the most intelligent dogs, is to raise the standard of the herd or race in each of these respeets by the simple aetion of heredity. Artificial selection has been called the "magieian's wand," by which the breeder can summon up whatever" animal form he will. If the parentage is chosen to a definite end, the process of heredity will develop the form 
desired by a force as unehanging as that by which a stream turns a mill.

From the wild animals about him man has developed the domestic animals which he finds useful. The dog whieh man trains to care for his sheep is developed by selection from the most tractable progeny of the wolf which onee devoured his flocks. By the proeess of artifieial selection those individuals that are not useful to man or pleasing to his fancy have been destroyed, and those which eontribute to his pleasure or welfare have been preserved and allowed to reproduce their kind. The various faney breeds of pigeons-the carriers, pouters, tumblers, ruff-neeks, and fan-tails-are all the descendants of the wild dove of Enrope (Columba livia). These brecds or raees or varieties have been produced by artifieial seleetion. So it is with the various breeds of cattle and of hogs and of horses and dogs.

In this artifieial seleetion new variations are morc rapidly produced than in Nature by means of intererossing different raees, and by a more rapid weeding out of unfarorable-that is, of undesirable-variations. The rapid production of variations and the caleful prescrvation of the desirable ones and rigid destruction of undesirable ones are the means by whieh many raees of domestic animals are produced. This is artificial sclection.

73. Dependence of species on species.-There was introduced into California from Australia, on young orange trees, a few years ago, an insect pest called the cottony cushion scale (Lecrya purchasi). This pest increased in numbers with extraordinary rapidity, and in four or five years threatcned to destroy eompletcly the great orange orehards of California. Artificial remedies were of little avail. Finally, an entomologist was sent to Australia to find out if this scale insect had not some special natural enemy in its native country. It was found that in Australia a certain species of lady-bird beetle attaeked and fed on the cottony 
cushion scales and kept them in eheck. Some of these lady-birds ( Vedalia cardinatis) were brought to California and released in a seale-infested orehard. The lady-birds, having plenty of food, thrived and produced many young. Soon the lady-birds were in sueh numbers that numbers of them eould be distributed to other orchards. In two or three years the Veclulias had beeome so numerous and widely distributed that the eottony eushion seales began to diminish perceptibly, and soon the pest was nearly wiped out. But with the disappearance of the scales came also a disappearanee of the lady-birds, and it was then diseorered that the Vedalias fed only on cottony eushion seales and could not live where the seales were not. So now, in order to have a stock of Tedalias on hand in California it is neeessary to keep protected some eolonies of the cottony cushion scale to serve as food. Of course, with the disappearanee of the predaeeous lady-birds the seale began to inerease again in rarions parts of the State, but with the sending of Vedalias to these localities the seale was again crushed. How close is the interdependence of these two species !

Similar relations ean be traced in erery group of animals. When the salmon cease to run in the Saeramento River in California the otter which feeds on them takes, it is said, to robbing the poultry-yards; and the bear, which also feeds on fish, strikes out for other game, taking fruit or chiekens or bee-lnives, whatever he may find. 


\section{CHAPTER VIII}

\section{ADAPTATIONS}

74. Origin of adaptations. - The strife for place in the crowd of animals makes it neeessary for eaeh one to adjust itself to the place it holds. As the individual beeomes fitted to its eondition, so must the speeies as a whole. The speeies is thereforc made up of individuals that are fitted or may become fitted for the eonditions of life. As the stress of existenee beeomes more severe, the individuals fit to continue the speeies are ehosen morc closcly. This choice is the antomatie work of the conditions of life, but it is none the less effeetive in its operations, and in the course of eenturies it becomes uncrring. When conditions change, the perfection of adaptation in a species may be the eause of its extinetion. If the nced of a special fitness can not be met immediatcly, the specics will disappcar. For example, the native shecp of England have developed a long wool fitted to protect them in a cool, damp elimate. Sueh sheep transferred to Cuba died in a short time, leaving no deseendants. The warm fleeec, so useful in England, rendered them wholly unfit for survival in the tropies. It is one advantage of man, as compared with other forms of life, that so many of his adaptations are cxternal to his strueture, and ean be east aside, when nceessity arises.

75. Classification of adaptations. - The various forms of adaptations may be roughly divided into five classes, as follows: ( $($ ) food securing, (b) sclf-protection, $(c)$ rivalry, $(d)$ defense of young, $(e)$ surroundings.

The few examples whieh are given under each elass, 
some of them striking, some not especially so, are mostly chosen from the vertebrates and from the insects, because these two groups of animals are the groups with which beginning students of zoölogy are likely to be familiar, and the adaptations referred to are therefore most likely to be best appreciated. Quite as good and obvious examples could be selected from any other groups of animals. The student

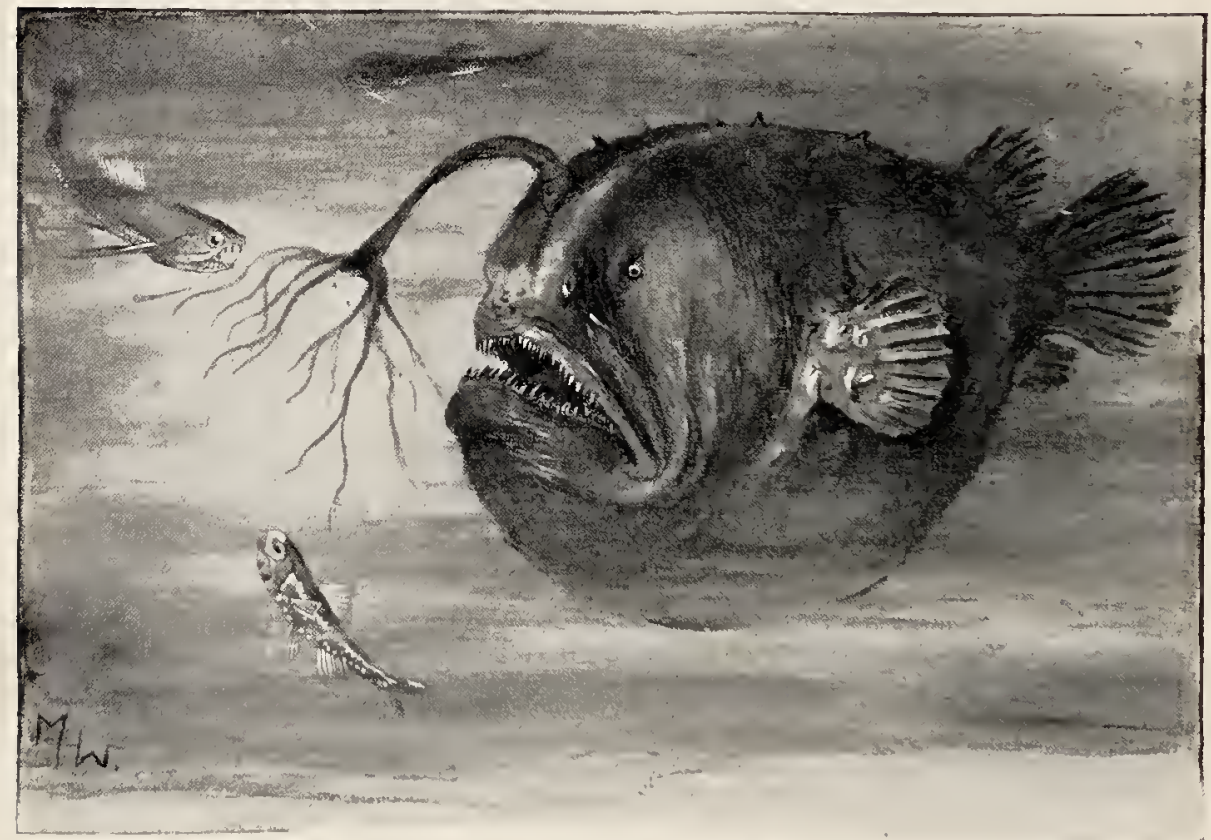

Fia. 54.-The deep-sen angler (Corynolophes reinhardti), which has a dorsal spine modified to be a luminons "fishing rod and lure," attracting lantern-fishes (Echiostome and Ethophora). An extraordmary adaptation for securing food. ('The angler is drawn after a figure of LÜTKEN's.)

will find good practice in trying to discover examples shown by the animals with which he may be familiar. 'That all or any part of the body structure of any animal can be called with truth an example of adaptation is plain from what we know of how the various organs of the animal body have come to exist. But by giving special attention to such adaptations as are plainly obvious, beginning stu- 
dents may be put in the way of independent observation along an extremely interesting and attractive line of zoölogieal study.

76. Adaptations for securing food.-For the purpose of eapture of their prey, some carnivorous animals are prorided with strong claws, sharp teeth, hooked beaks, and other struetures familiar to us in the lion, tiger, dog, eat, owl, and eagle. Inseeteating mammals have eontrivanees espeeially

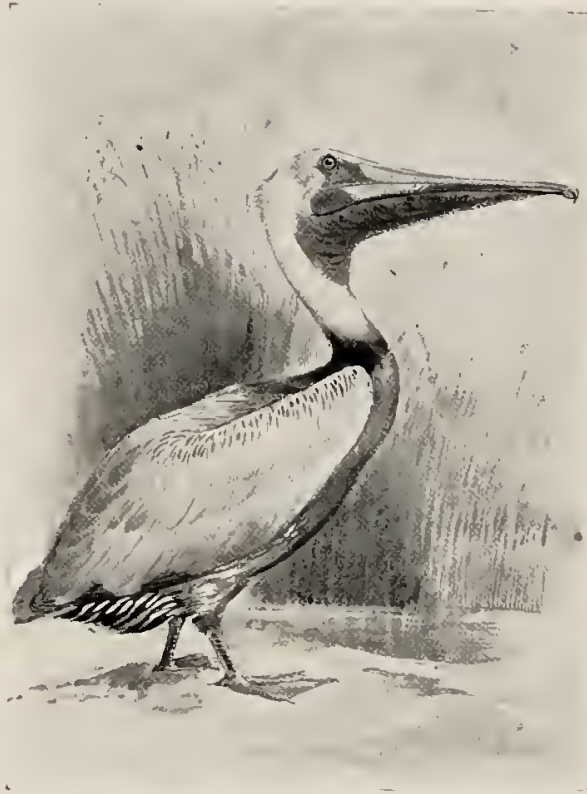

Fig. 55.-The brown pelican, showing gular sac, which it uses in catching and holding fishes that form its food.

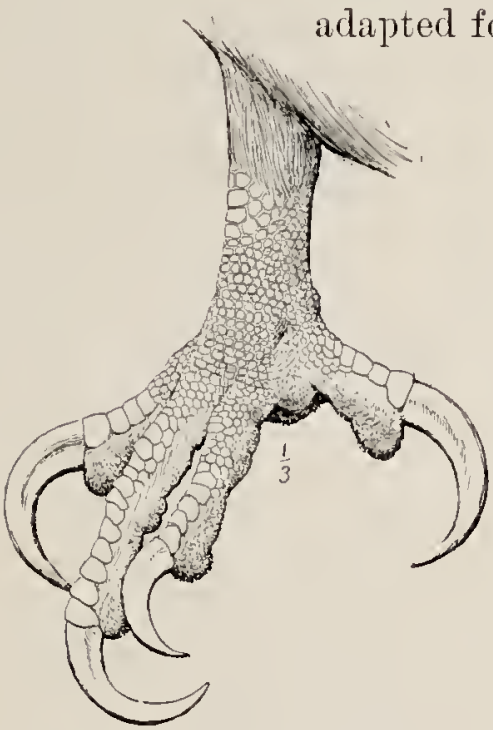

Fig. 56.-Foot of the bald eagle, showing claws for seizing its prey. (ChapMan.)

$r$ the eatehing of inseets. The ant-eater, for example, has a eurious, long sticky tongue which it thrusts forth from its eylindrieal snout deep into the recesses of the anthill, bringing it out with its stieky surface covered with ants. Animals whieh feed on nuts are fitted with strong teeth or beaks for craeking them. Similar teeth are found in those fishes which feed on crabs, snails, or sea-urchins. Those mammals like the horse and eow, that feed on plants, have usually 


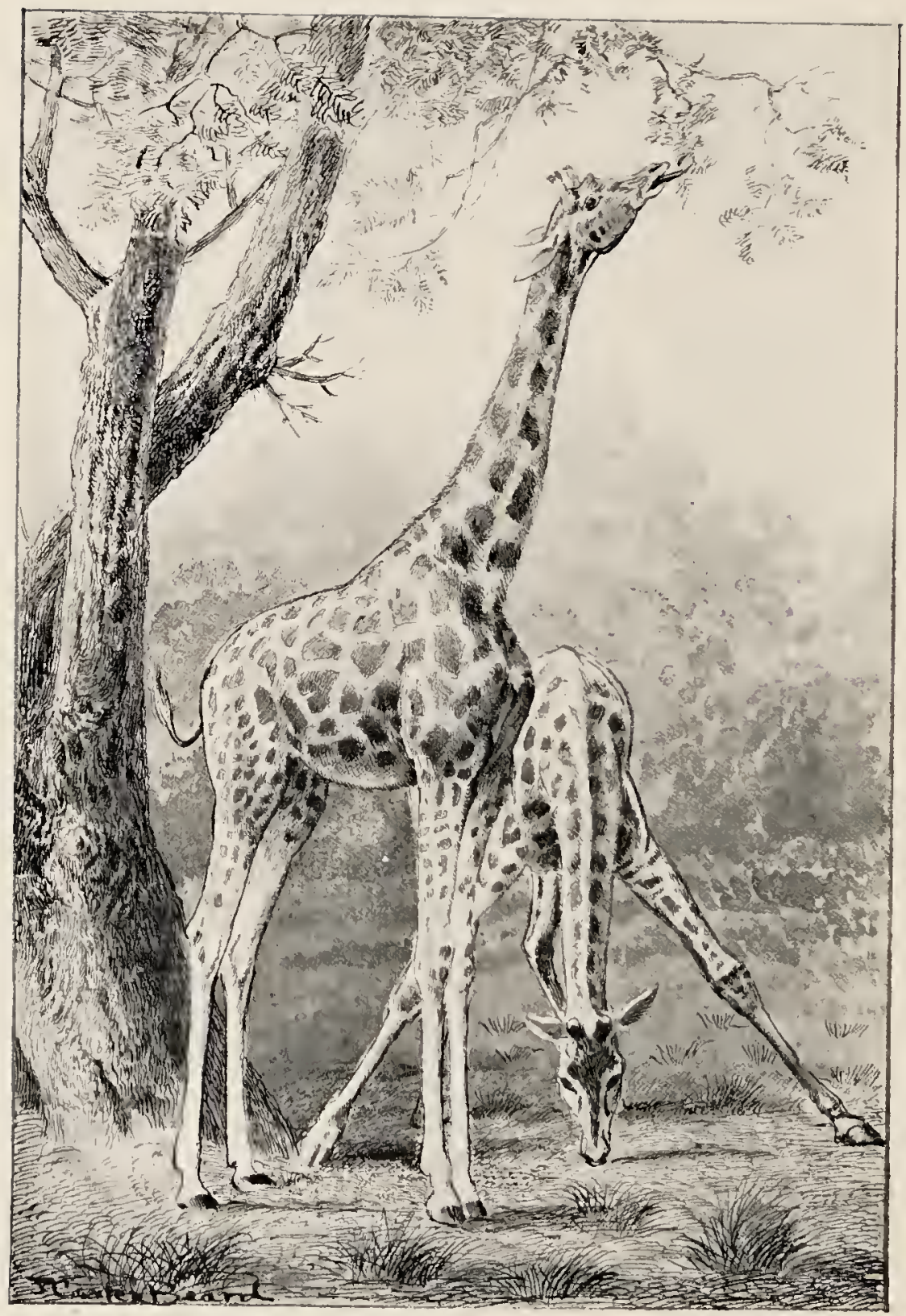

Fig. 5\%,-Giraffes feeding. 
broad ehisel-like ineisor teeth for eutting off the foliage, and teeth of rery similar form are developed in the dif-

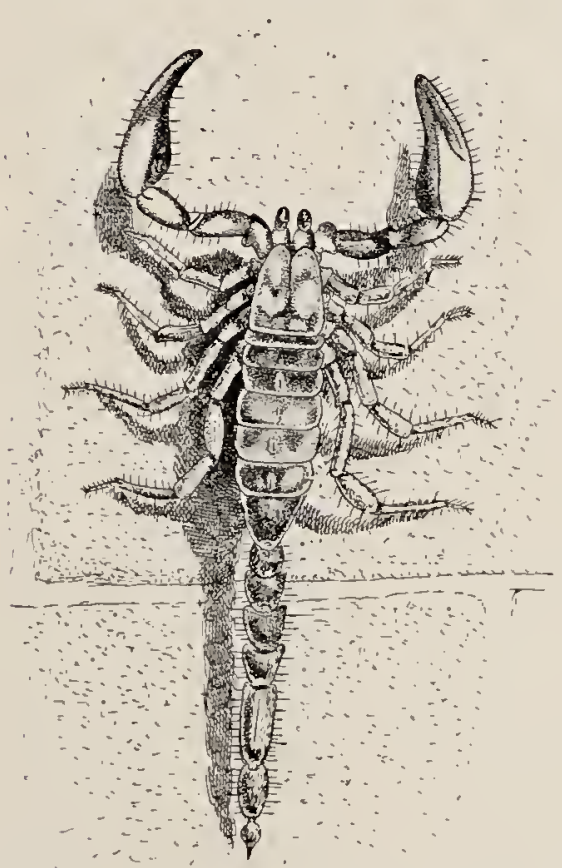

Fit. 58-Scorpion, showing the special development of certain mouth parts (the maxillary pilpi) as pincer-like organs for grusping prey. At the postcrior tip of the borly is the poisonons sting. ferent groups of planteating fishes. Molar teeth are found when it

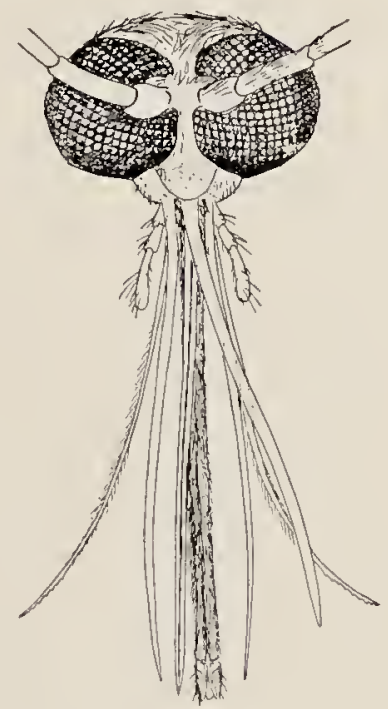

Fitr. 59,-Head of mosquito (fenlale), showing the piereing needle-like mouth parts which rompose the "bill."

is neeessary that the food should be erushed or vhewed, and the sharp canine teeth go with a flesh diet. The long neek of the giraffe (Fig. 5y) enables it to browse on the foliage of trees.

Inseets like the leafbeetles and the grasshoppers, that feed on the foliage of plants, have a pair of jaws, broad but

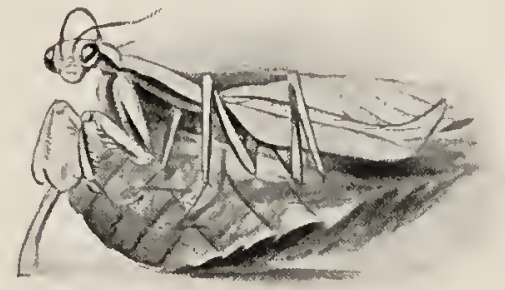

Fla, 60. -The frayng-horse (1/antis) with fore legs developed as grasping organs. 
sharply edged, for cutting off bits of leaves and stems. Those which take only liquid food, as the butterflies and sucking-bugs, have their mouth parts modified to form a slender, hollow sucking beak or proboscis, which can be

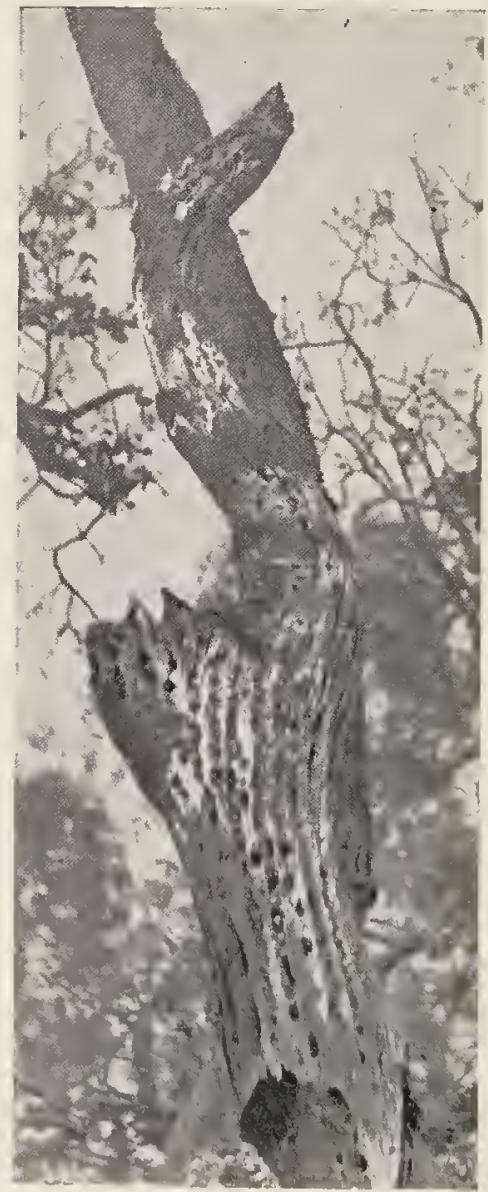

Hig. 61.- Mcorus put into bark of tree by the Califoruian woodjecker (Nelunerpes fomnicicorous buirdii). - From photograph, Stanford University, Califoruia. prey; but these as well as
other animals may protect themsclves in other fashions. Most of the hoofed animals arc provided with horns, strucor into the green tissue of plants or the flesh of animals, to suck up nectar or plant sap or blood, depending on the special food habits of the insect. The honey-bee has a very complicated equipment of mouth parts fitted for taking either solid food like pollen, or liquid food like the nectar of flowers. The mosquito has a "bill" (Fig. 59) composed of six shar"p, slender needles for piercing and lacerating the flesh, and a long tubular under lip through which the blood can flow into the mouth. Some predaceous insects, as the praying-horse (Fig. 60), have their fore legs developed into formidable grasping organs for seizing and holding their prey.

\%\%. Adaptation for self-defense.-For self-protcction, carnivorous animals use the same weapons to defend themselves which serve to sccure their thrust into a flower ncctary, (n) 


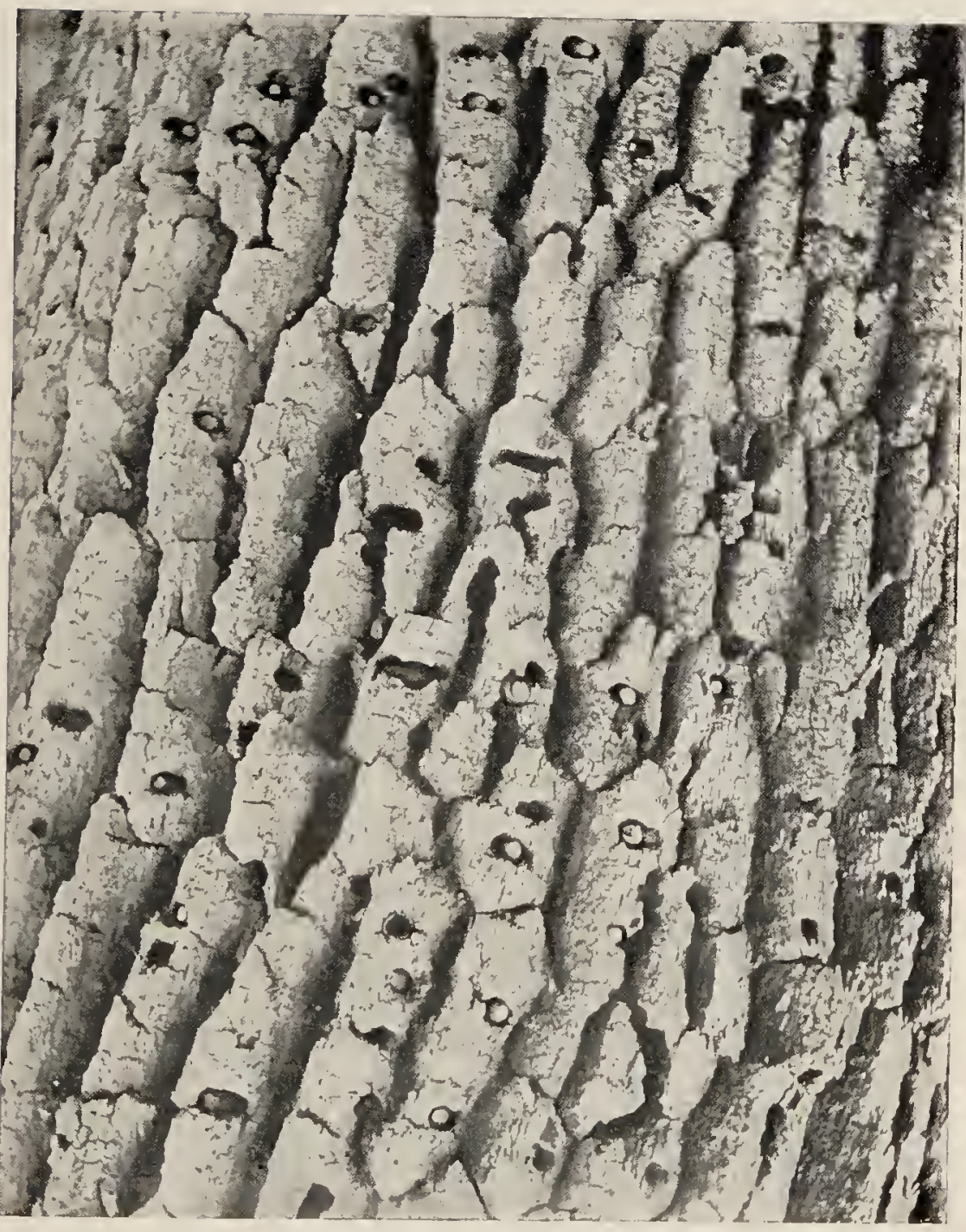

Fig. 62.-Section of bark of live oak tree with acorus placed in it by the Culifornian woodpecker (Melanerpes fornicivorous bairdii). - Fron photograph, Stanford University, California.

tures useless in proeuring food but often of great effeetiveness as weapons of defense. To the category of structures useful for self-defense belong the many peenliarities of coloration known as "recognition marks." These are marks, 
not otherwise useful, which are supposed to enable members of any one species to recognize their own kind among the mass of animal life. To this category belongs the

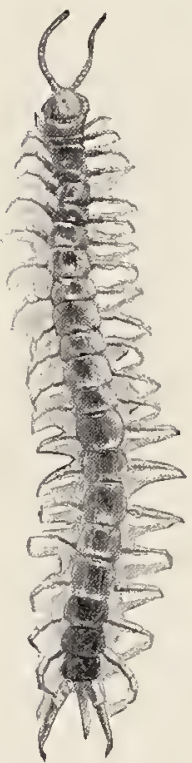

Fig. 03.-Centiped. The foremost pair of legs is modified to be a pair of seizing and stinging organs. An adaptation for self-defense and for securing food. black tip of the weasel's tail, which remains the same whatever the changes in the outer fur. Another example is seen in the white outer feathers of the tail of the meadow-lark as well as in certain sparrows and warblers. The white on the skunk's back and tail serves the same purpose and also as a warning. It is to the skmk's adrantage not to be hidden, for to be seen in the crowd of animals is to be avoided by them. 'The songs of birts and the calls of various creatures serve also as recognition marks. Each species knows and heeds its own characteristic song or cry, and it is a source of mutual protection. The fur-scal pup knows its mother's call, eren though ten thousand other mothers are calling on the rookery.

The ways in which animals make themselves disagreeable or dangerous to their captors are almost as varied as the animals themsolves. Besides the teeth, cliws, and horns of ordinary attack and defense, we find among the mammals many special structures or contrivances which serve for defense through making their possession mpleasant. The scent glands of the skunk and its relatives are noticed above. The poreupine has the bristles in its fur specialized as quills, barbed and detachable. These quills fill the mouth of an attacking fox or wolf, and serve well the purpose of defense. The hedgehog of Europe, an animal of different nature, being related rather to the mole than to 
the squirrel, has a similar armature of quills. The armadillo of the tropies has movable shields, and when it withdraws its

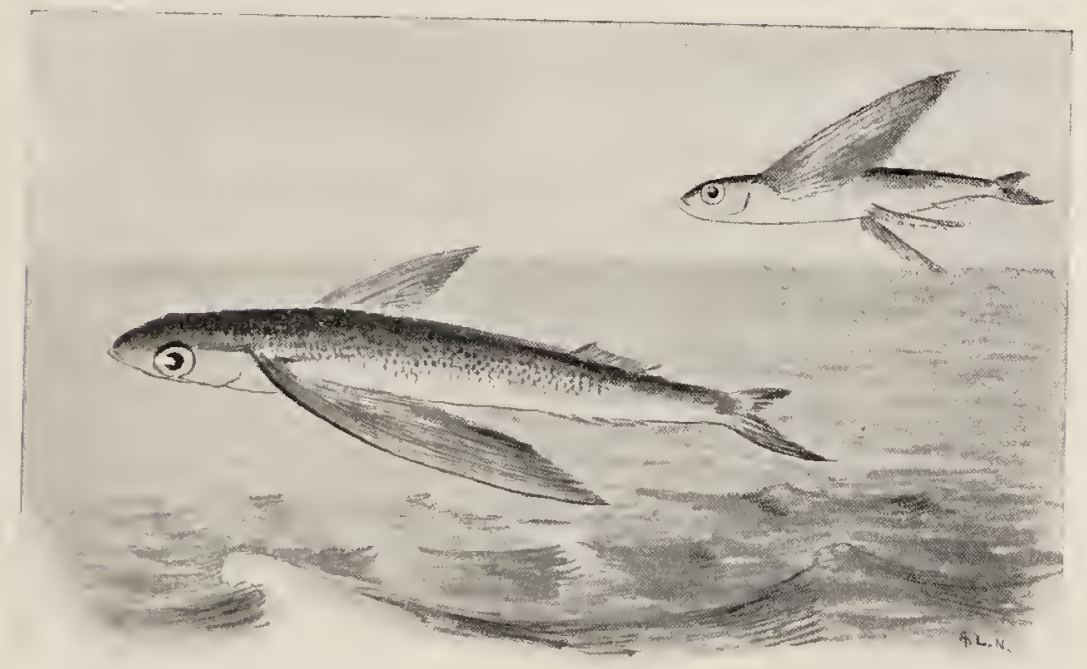

Fia. 64.-Flying fishes. (The upper one a species of Cypselurus, the lower of Exocotus.) These fishes escape from their enemies by leaping into the air and sailing or "flying" long distances.

head (which is also defended by a bony shield) it is as well protected as a turtle.

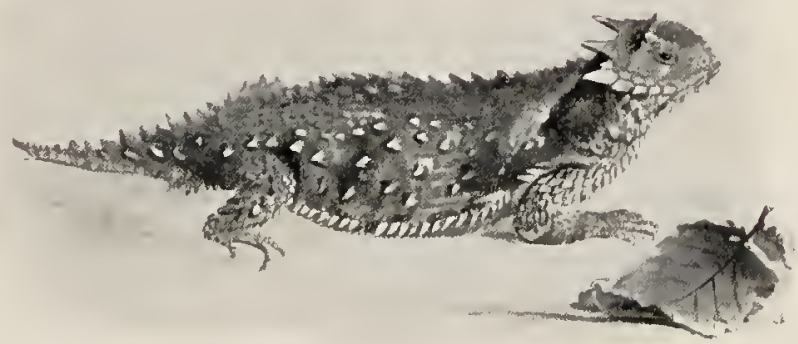

FIg. 65.-The horned toad (Phrynosoma blainvillei). The spiny covering repels many enemies.

Speeial organs for defense of this nature are rare among birds, but numerous among reptiles. The turtles are all 
proteeted by bony shields, and some of them, the box-turtles, may elose their shields almost hermetieally. The snakes broaden their heads, swell their neeks, or show their forked tongues to frighten their enemies. Some of them

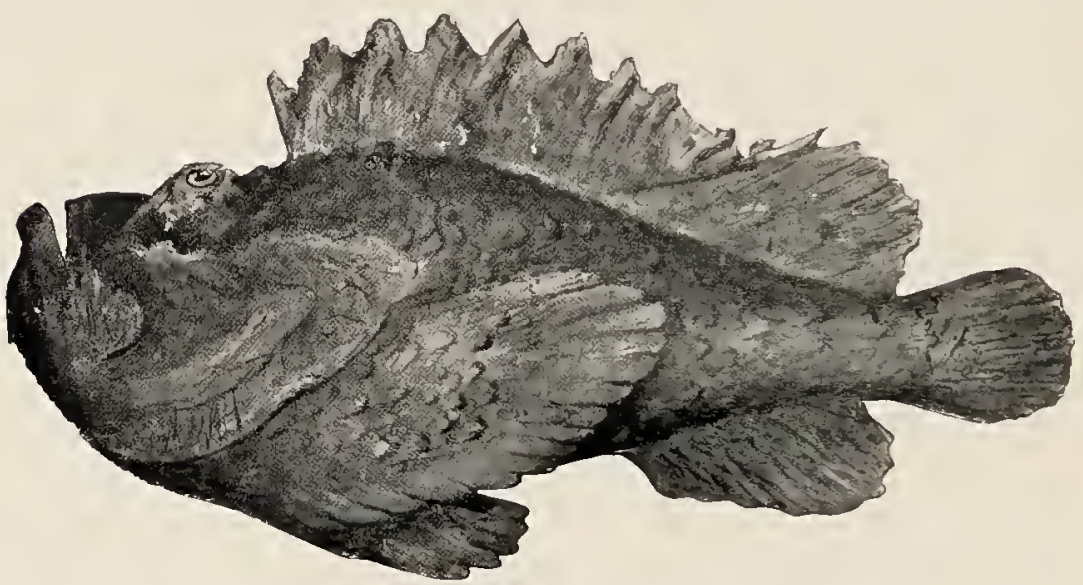

Fig. 66.--Nokee or poisonons scorpion-fish (Emmydrichthys vulcanus) with poisonons spines, from Tahitj.

are further armed with fangs eomeeted with a venom gland, so that to most animals their bite is deadly. Besides its fangs the rattlesnake has a rattle on the tail made up of a

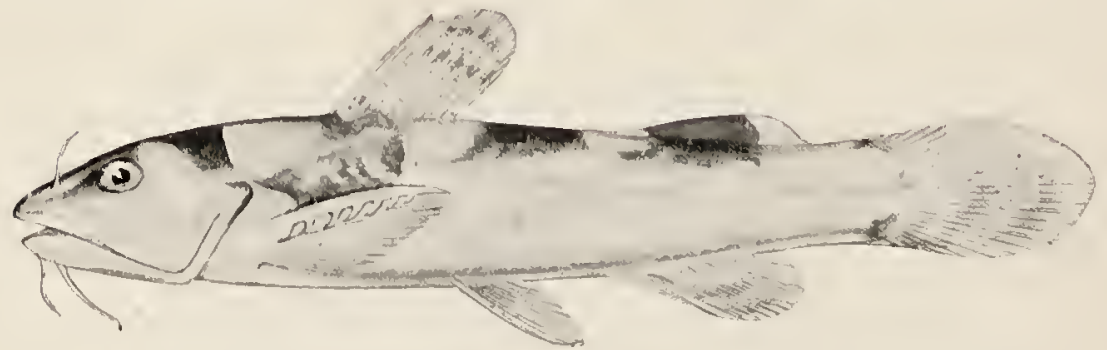

Mig. 67.-Mad tom (Schilbcodes furiosus) with poisoned pectoral spine.

suecession of bony elappers, modified vertebre, and seales, by which intruders are warned of their presenee. 'This sharp and insistent buzz is a warning to animals of other speeies and a reeognition signal to those of its own kind. 
Even the fishes have many modes of self-defense through giving pain or injury to those who would swallow them. The cat-fishes or horned pouts when attaeked set immovably the sharp spine of the pectoral fin, inflieting a jagged round. Pelieans who have swallowed a eatfish have been known to die of the wounds inflicted by the fish's spine. In the group of scorpionfishes and toad-fishes are eertain genera in which these spines are provided with poison glands. 'These may inflict very severe wounds to other fishes, or even to birds or man. One of this group of poison-fishes is the nokee (Emmydrichthyss, Fig. 66). A group of small freshwater eat-fishes, known as the mad toms (Fig. 6\%), have also a poison gland attaehed to the peetoral spine, and its sting is most exasperating, like the sting of a wasp. The sting-rays (Fig. 68) of many speeies Fid. 68. $-\Lambda$ sting ray have a strong, jagged spine on the tail, eovered with slime, and armed with broad (Crolophlus goodei), from Panama.

saw-like teeth. This inflicts a dangerous wound, not through the presenee of speeifie venom, but from the danger of blood poisoning arising from the slime, and the ragged or unclem cut.

Many fishes are defended by a eoat of mail or a coat of sharp thorns. The globe-fishes and porcupine-fishes (Fig. 69) are for the most part defended by spines, but their instinet to swallow air gives them an additional safeguard. When one of these fishes is disturbed it rises to the surface, 
gulps air until its capacious stomach is filled, and then floats belly upward on the surface. It is thus protected from other fishes, though casily taken by man. The torpedo, electric eel, elcetric cat-fish, and star-gazer, surprise and

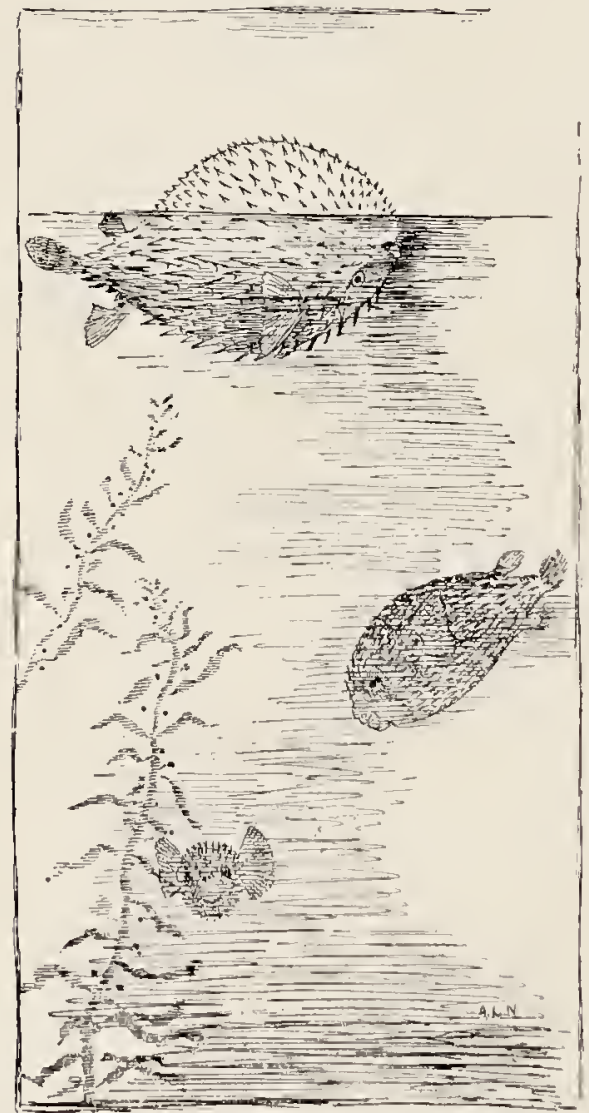

Fre. (i9.-l'ol'cupine-fish (7)indon, hystrix), the lower ones swimming normally, the mpper one flouting belly upwarl. with inllated stomacli. - Hawn from specimens from the rlorida líys. staggel their captors by means of clectric shocks. In the torpedo or electric ray (Fig. ro), found on the sandy shores of all warm seas, on either side of the head is a large honeycomb-like structure which yields a strong electric shock whenever the live fish is tonched. This shock is felt sererely if the fish be stabbed with a knife or metallic spear. The electric eel of the rivers of Paraguay and southern Brazil is said to give severe shocks to herds of wild horses driven through the strcims, and similar accounts are given of the clectric cat-fish of the Nile.

Among the insects, the possession of stings is not uncommon. The wasps and bees arc familiar cxamples of stinging insects, but many other kinds, less familiar, are similarly protected. All insects have their bodies covered with a coat of armor, composed of a horny substance called chitin. In some cases this chitin- 
ous coat is very thick and serves to protect them effectually. This is especially true of the beetles. Some inseets are inedible (as mentioned in Chapter XII), and are conspieuously colored so as to be readily reeognized by insectivorous birds. The birds, knowing by experienee that these insects are ill-tasting, aroid them. Others are effeetively eoneealed from their enemies by their close resemblance in color and marking to their surroundings. These proteetive resemblanees are discussed in Chapter XII.

\%8. Adaptation for rivalry. - In questions of attaek and defense, the need of mecting animals of their owu kind as well as animals of other races must be eonsidered. In struggles of speeies with those of their own kind, the term rivalry may be applied. Actual warfare is confined mainly to males in the breeding season and to polygamous animals. Among those in which the male mates with many fomales, he must struggle with other males for their possession. In all the groups of vertebrates the sexes are about equal in numbers. Where mating exists,

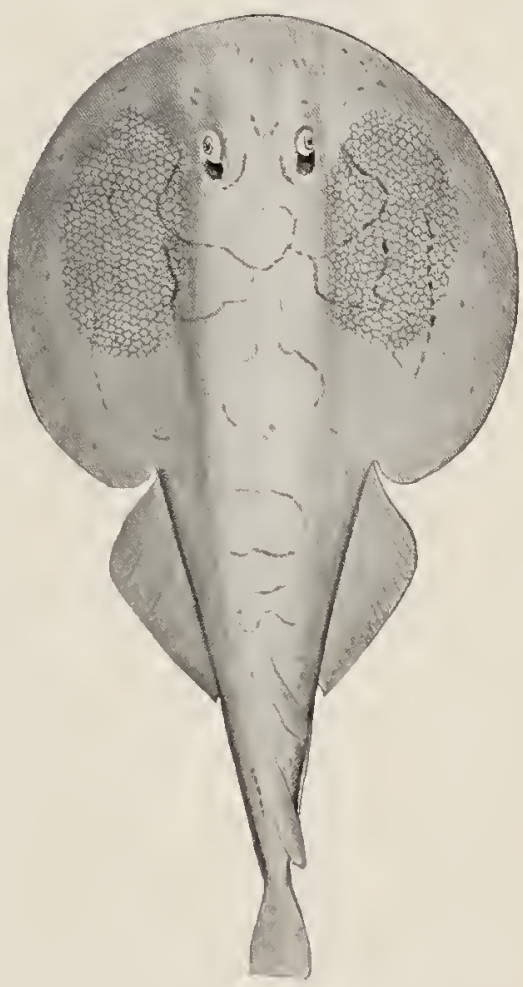

Fis. ro.-Torpeclo or electric ray (Narcine braxiliensis), showing electric cells. either for the season or for life, this eondition does not involve serious struggle or destruetive rivalry.

Among monogamous birds, or those which pair, the male eourts the female of his ehoice by song and by display 


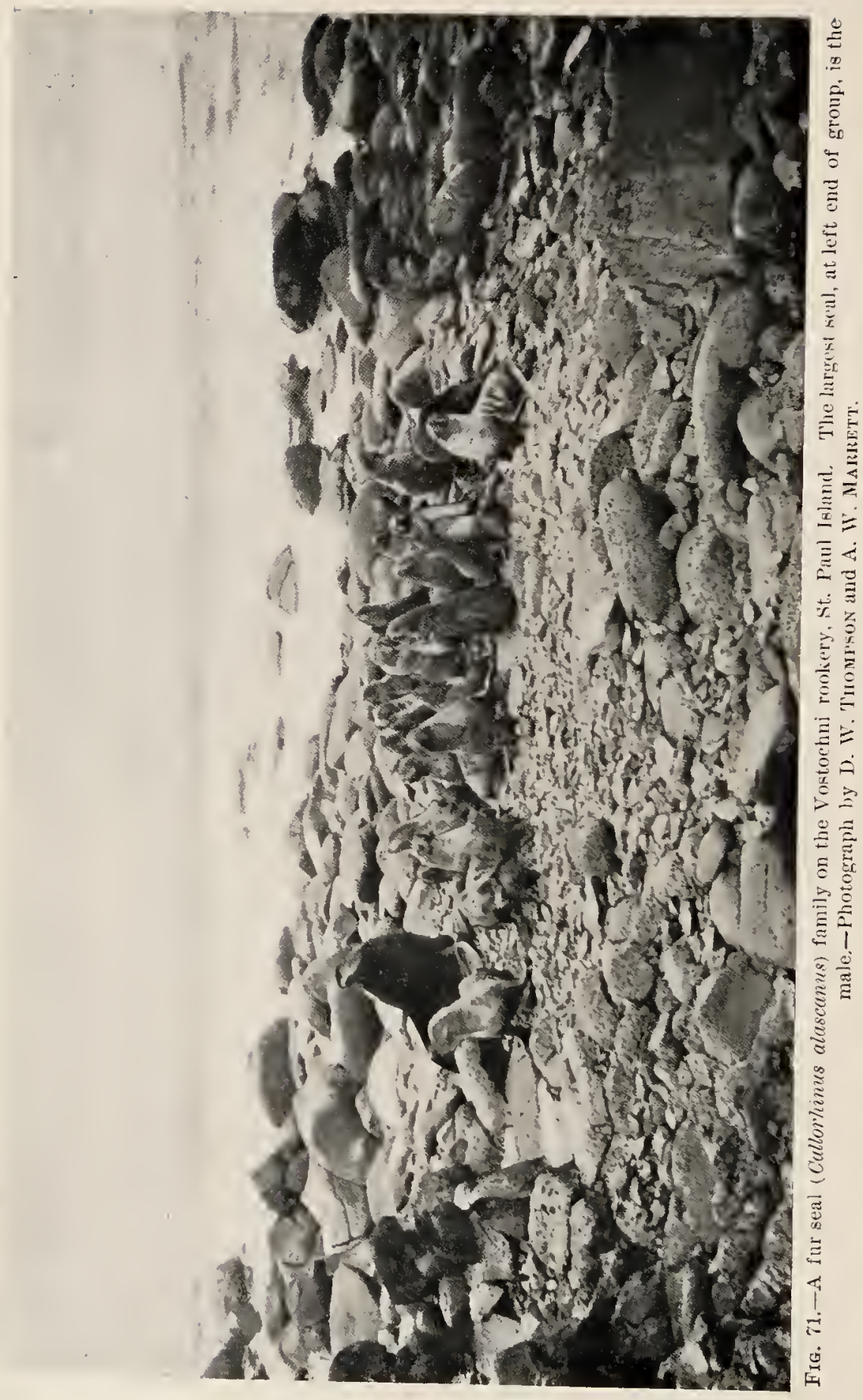


of his bright feathers. The female consents to be chosen by the one which pleases her. It is believed that the handsomest, most vivacious, and most musical males are the ones most successful in such courtship. With polygamous animals there is intense rivalry among the males in the mating season, which in almost all species is in the spring. 'The strongest males survive and reproduce their strength. The most notable adaptation is seen in the superior size of teeth, horns, mane, or spurs. Among the polygamous fur scals (Fig. \%1) and sea lions the male is about four times

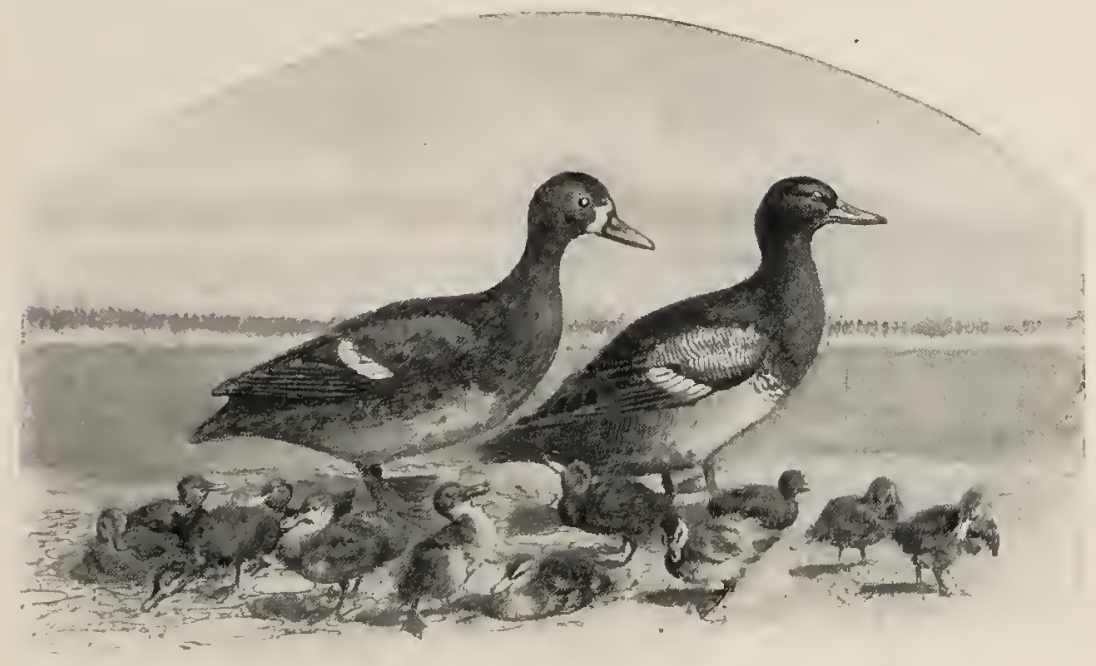

FIG. F,-The Arctic black duck. Male, female, and prococial young.

the size of the female. In the polygamous family of deer, buffalo, and the domestic cattle and shcep, the male is larger and more powcrfully armed than the fcmale. In the polygamous group to which the hen, turkey, and peacock bclong the males possess the display of plumagc, and the structures adapted for fighting, with the will to use them.

79. Adaptations for the defense of the young.--The protection of the young is the source of many adaptive structures as well as of the instincts by which such structures are 
utilized. In general, those animals are highest in derelopment, with best means of holding their own in the struggle

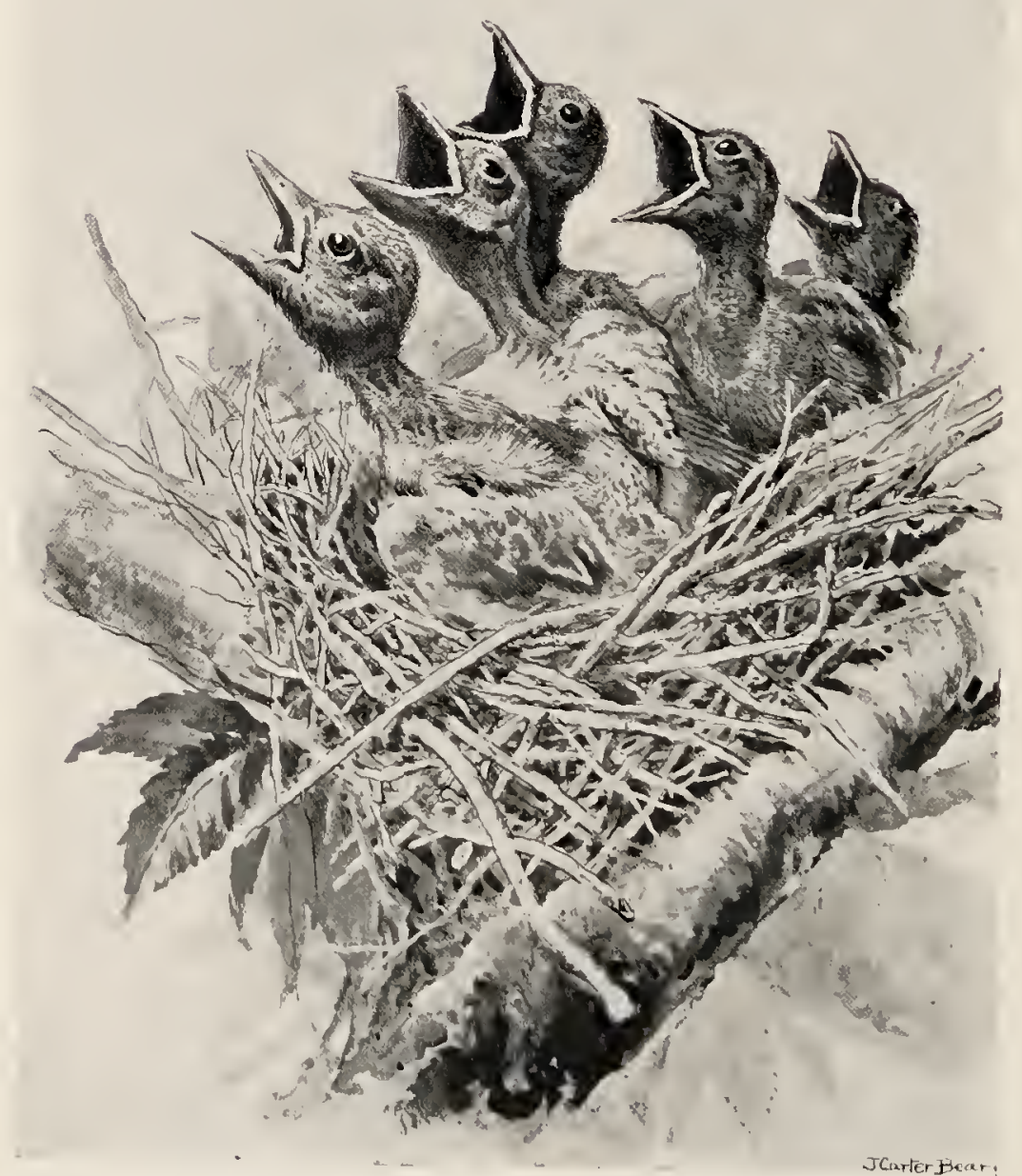

Fia. 73. -The altricial nestlings of the Canada jay (Perisoreus canadensis).

for life, that take best care of their young. The homes of animals are elsewhere specially disenssed (see Chapter 
$X V)$, but those instincts which lead to home-building may all be regarded as useful adaptations in preserving the young. Among the lower or more coarsely organized

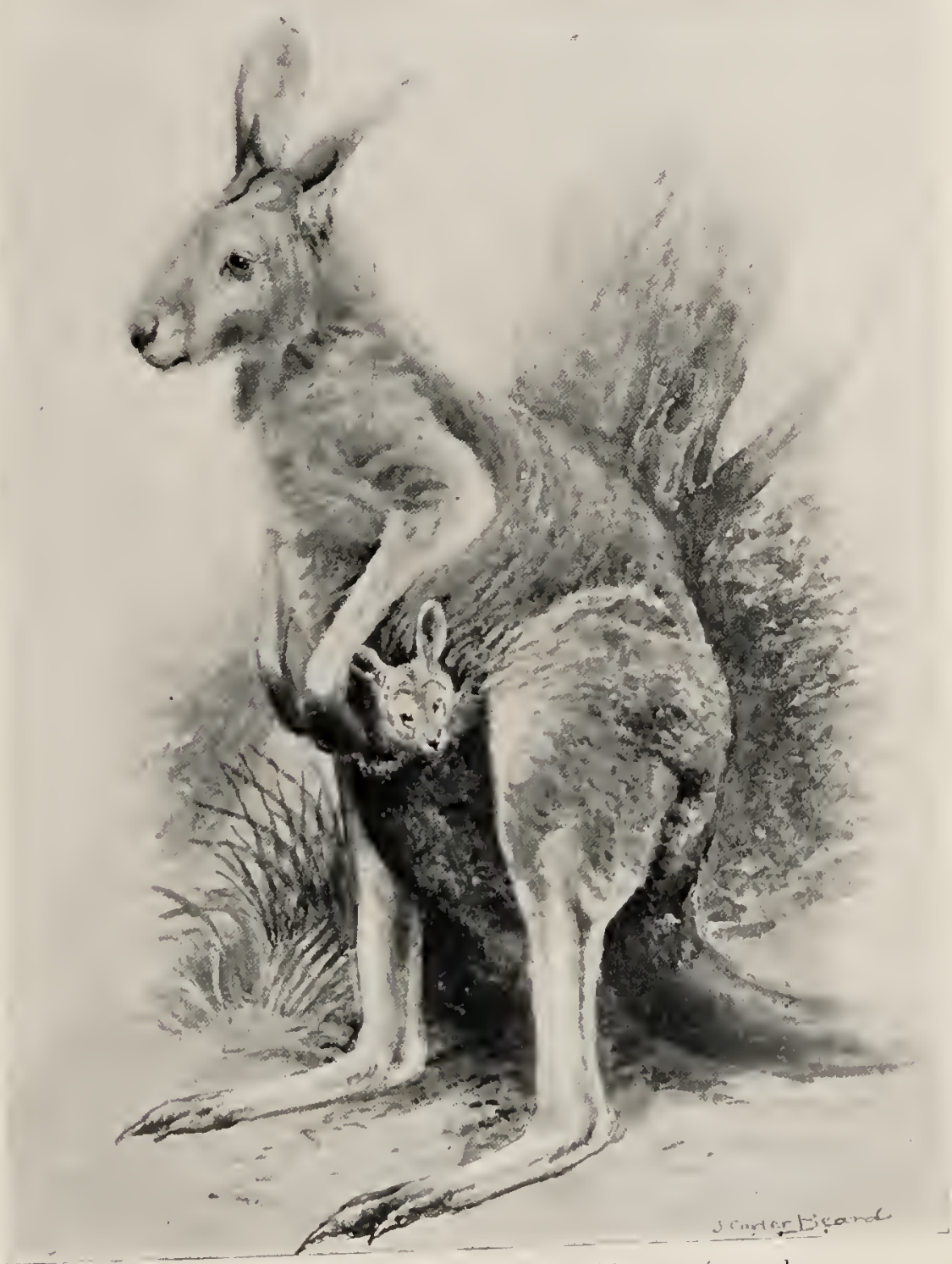

FIG. it.-Kangaroo (Macroms rufus) with young in pouch. 
birds, sueh as the ehieken, the duck, and the auk, as with the reptiles, the young animal is hatehed with well-derel-

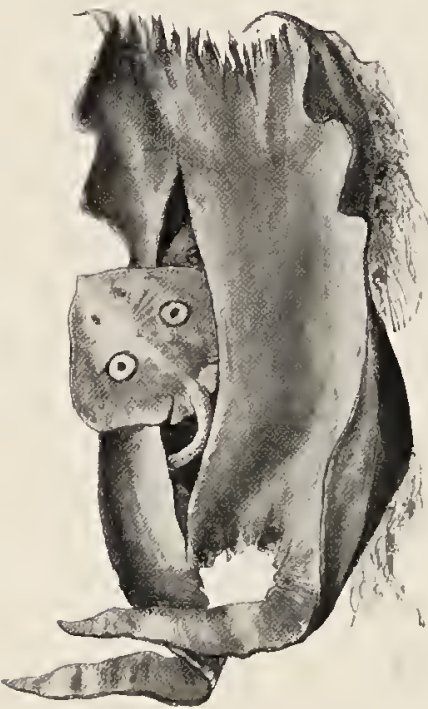

Frg. \%r.-Egg case of California barn-door skate ( Rujubinoculata) cut open to show young inside. (Young issues naturally at oure (nd of the case.) oped muscular system and sense organs, and is capable of running about, and, to some extent, of feeding itself. Birds of this type are known as precocial (Fig. $7 \%$ ), while the name altricial (Fig. 73 ) is applied to the more highly organized forms, such as the thrushes, doves, and song-birds gencrally. With these the young are hatched in a wholly helpless condition, with ineffective muscles, deficient senses, and dependent wholly upon the parent. The altricial condition demands the building of a nest, the establishment of a home, and the continued care of one or both of the parents.

The very lowest mammals known, the duck-bills (Monotremes) of Australia, lay large eggs in a horny shell like those of a turtle, and guard them with great jealousy. But with ahnost all mammals the egg is very small and without mueh food-yolk. The egrg begins its development within the body. It is nomished by the blood of the mother, and after birth the young is cherished by her, and fed by milk secreted loy specialized glands of the skin. All these features are adaptations tending toward the preservation of the young. In the

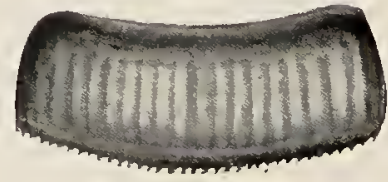

FIG. T6.--Egrt-case of the cockronch.

division of mammals next lowest to the Monotremes-the kangaroo, opossum, etc.- the young are boln in a very immature state and are at once seized by t'ie mother and 
thrust into a poueh or fold of skin along the aboiomen, where they are kept until they are able to take carc of themselves (Fig. 74 ). This is an interesting and ingenious adaptation, but less specialized and less perfect an adaptation than the conditions found in ordinary mammals.

Among the insects, the special provisions for the protection and eare of the eggs and the young are wide-spread and various. Some of those adaptations which take the speeial form of nests or "homes" will be described in a later ehapter (see Chapter $\mathrm{XT}$ ). The eggs of the common eockroach are laid in small packets inclosed in a firm wall

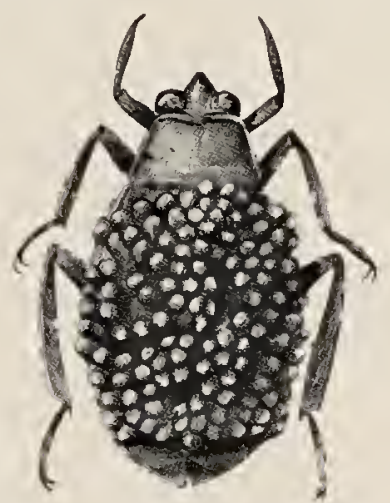
(Fig. 76). The eggs of the great water-bugs are earricd on the baek of the male (Fig. $\% \%$ ); and the spiders lay their eggs in a silken sac or eocoon, and some of the ground or

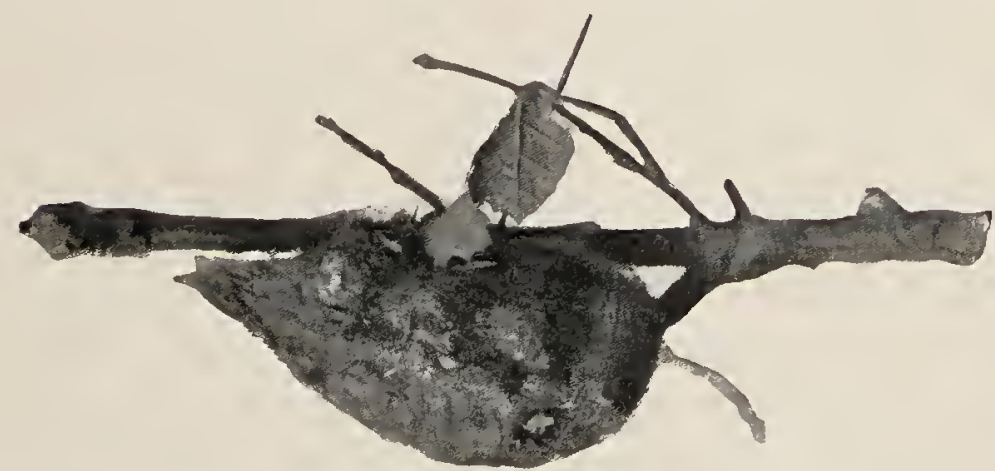

FIG. 78. - Cocoon inclosing the pupa of the great Cecropia moth. Spun of silk by the larva before pupation.

running spiders (Lycosida) drag this egg-sac, attached to the tip of the abdomcu, about with them. The young spiders when hatched live for some days inside this sae, feeding on each other! Many insects have long, sharp, 
piercing ovipositors, by means of which the eggs are deposited in the ground or in the leaves or stems of green plants, or even in the hard wood of tree-trunks. Some of

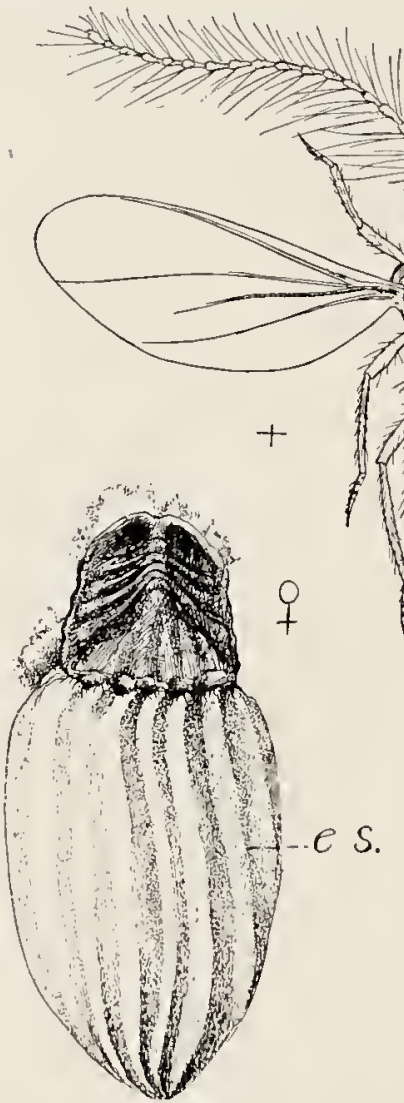

Fia. 79.-The cottony collicm sale inseret (cerya purchesi), from Califonill. The male is winged, the f(male: wingless and with a large waxen cogg-sac $\left(e_{0} s_{\text {. }}\right)$ attached to her bolly. (The lines at the left of each figure indicate the size of the insectr.)

gnaws its way out. Sueh inseet galls are espeeially abundant on oak trees (Fig. 80). 'The eare of the eggs and the young of the social inseets, as the bees and ants, are described in Chapter IX. 
S0. Adaptations concerned with surroundings in life.-A large part of the life of the animal is a struggle with the environment itself; in this struggle only those that are adapted live and leave deseendants fitted like themselves. The fur of mammals fits them to their surroundings. As the fur differs, so may the habits ehange. Some animals are aetive in winter; others, as the bear, hibernate, sleeping in eaves or hollow trees or in burrows until eonditions are favorable for their aetivity. Most suakes and lizards hibernate in eold weather. In the swamps of Louisiana,
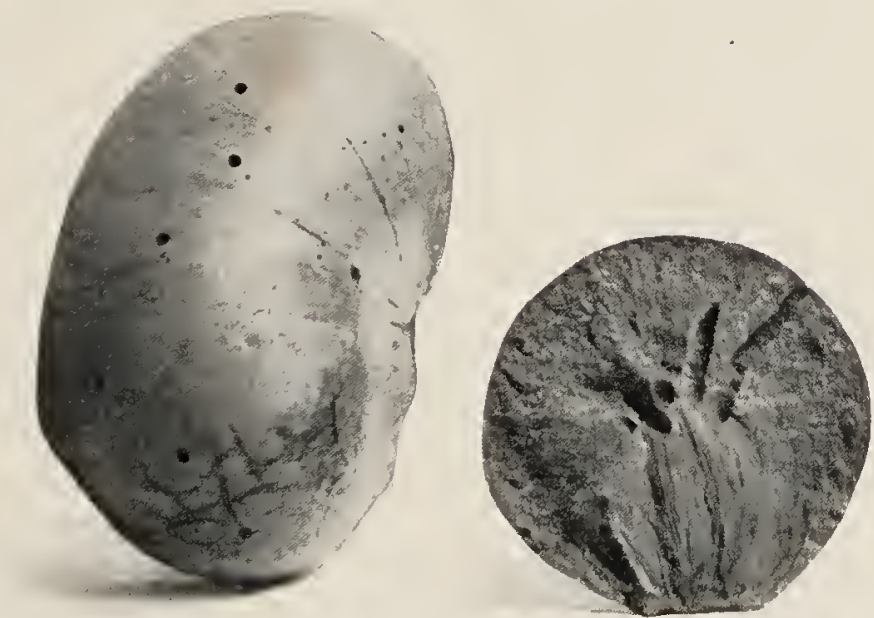

FIG. 80. -The giant gall of the white oak (California), made by the gall insect, Andricus californicus. The gall at the right cut open to show tunnels made by the insects in escaping from the gall.-From photograpl.

in winter, the bottom may often be seen eovered with water snakes lying as inert as dead twigs. Usually, however, hibernation is aeeompanied by eoneealment. Some animals in hibernation may be frozen alive withont apparent injury. The blaekfish of the Alaska swamps, fed to dogs when frozen solid, has been known to revive in the heat of the dog's stomaeh and to wriggle out and eseape. As animals resist heat and eold by adaptations of strueture or habits, so may they resist dryness. Certain fishes hold reservoirs 
of water above their gills, by means of which they can breathe during short excursions from the water. Still others (mud-fishes) retain the primitive lung-like structure of the swim-bladder, and are able to breathe air when, in the dry season, the water of the pools is reduced to mud.

Another series of adaptations is concerned with the places chosen by animals for their homes. The fishes that

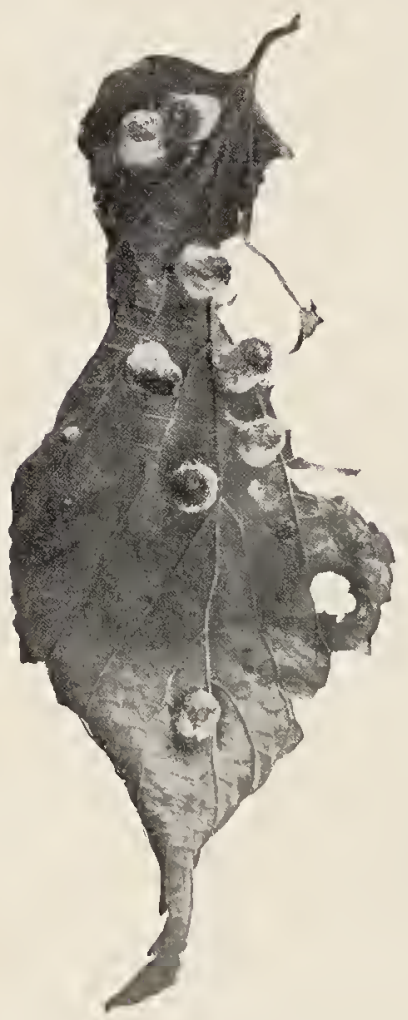

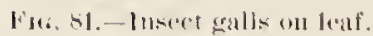

live in water have special organs for breathing under water (Fig. 8\%). Many of the South American monkeys hare the tip of the tail adapted for clinging to limbs of trees or to the bodies of tother monkeys of its own kind. The hooked claws of the bat hold on to rocks, the bricks of chimneys, or to the surface of hollow trees where the bat sleeps through the day. " The tree-frogs (Fig. 83) or tree-toads have the tips of the toes swollen, forming little pads by which they cling to the bark of trees.

Among other adaptations relating to special surroundings or conditions of life are the great cheek pouches of the pocket gophers, which carry off the soil dug up by the large shorcl-like feet when the gopher excavates its burrow.

Those insects which live undergromnd, making burrows or tunnels in the soil, have their legs or other parts adapted for digging and burowing. 'The mole cricket (Fig. 84) has its legs stout and short, with broad, shorel-like feet. Some watcr-beetles (Fig. 85) and watcr-bugs have one or morc of the pairs of legs flattened and broad to serve as oars or pad. dles for swimming. The grasshoppers or locusts, who leap, 
have their hind legs greatly enlarged and elongated, and provided with strong museles, so as to make of them "leaping legs." The grubs

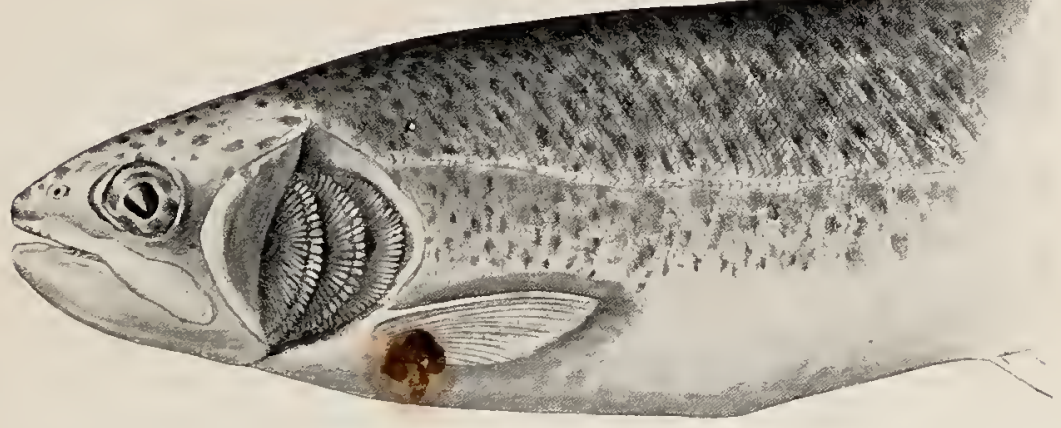

Fig. 8\%.-1Head of rainbow trout (Salmo irideus) with gill cover bent back to show gills, the breathing organs.

or larve of beetles whieh live as "borers" in tree-trunks have mere rudiments of legs, or none at all (Fig. 86). They have great, strong, biting jaws for eutting away the hard wood. They move simply by wriggling along in their burrows or tumnels.

Inseets that live

in water either eome up to the surfaee to breathe or take dorm air underneath their wings, or in some other way, or have gills for breathing the air whieh is mixed with the water. These gills are speeial adap-

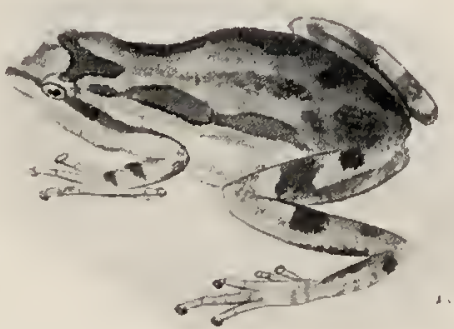

Fig. 83.--Tree-toad (Hyle regilla). tive struetures which present a great variety of form and appearanee. In the young of the May-flies they are delieate plate-like flaps projeeting from the sides of the body. They are kept in eonstant motion, gently waving baek and 
forth in the water so as to maintain eurrents to bring fresh water in eontaet with them. Young mosquitoes (Fig. 8\%)

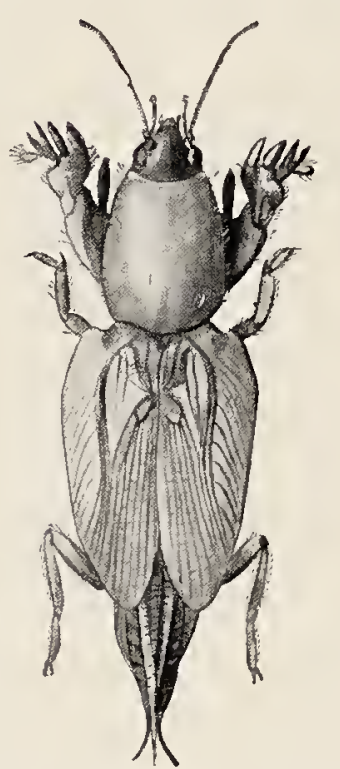

FIG. 81. - The mole cricket ( Gryllotalpa), with fore feet modified for digging. do not have gills, but eome up to the surfaee to breathe. The larvæ, or wrigglers, breathe through a speeial

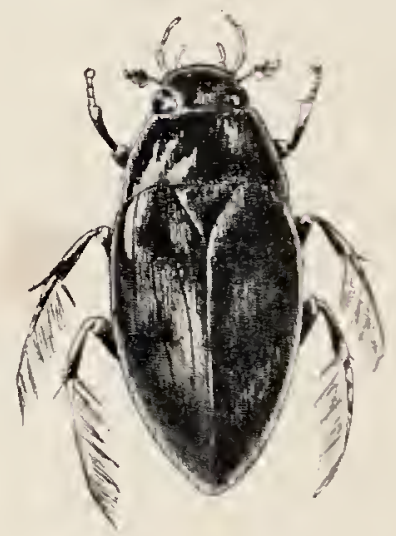

Fia. 85.-A water-beetle (IIydrophilus).

tube at the posterior tip of the body, while the pupie have a pair of horn-like tubes on the baek of the head end of the body.

81. Degree of structural change in adaptations.- Thile among the higher or vertebrate animals, espeeially the fishes and reptiles, most remarkable cases of adaptations ocenr, yet the struetural ehanges are for the most part external, never seriously affecting the development of the internal organs other than the skeleton. The organization of these higher animals is mueh less plastie than among the invertebrates. In

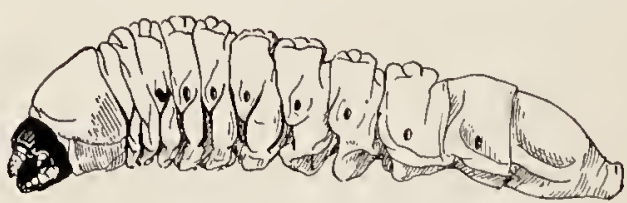

Fut, 86.- Wood-boring beetle larva (Prionus). general, the higher the type the more persistent and unchangeable are those struetures not immediately exposed 
to the influence of the struggle for cxistence. It is thus the outside of an animal that tells where its ancestors have lived. The inside, suffering little change, whaterer the surroundings, tells the real nature of the animal.

82. Vestigial organs.-In general, all the peculiaritics of animal structure find their explanation in some necd of adaptation. When this need ceases, the structure itself tends to disappear or else to serve some other necd. In the bodies of most animals there are certain incomplctc or rudimentary organs or structures which serve no distinct useful purposc. They are structures which, in the ancestors of the animals now possessing them, wcre fully developed functional organs, but which, bccause of a change in habits or conditions of living, are of no further need, and are gradually dying out. Such organs are called vestigial organs. Examples are the disused ear muscles of man, the

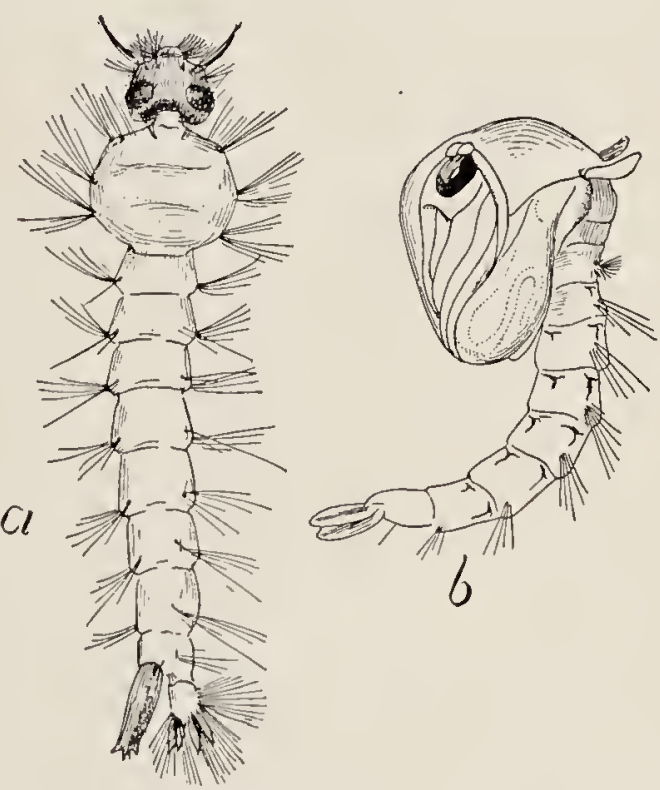

Fra. bir.-Young stages of the mosquito. $a$, larva (wriggler) ; $b$, pupa. vermiform appendix in man, which is the reduced and now uselcss anterior end of the large intestinc. In the lowcr animals, the thumb or degeneratc first finger of the bird with its two or threc little quills serves as an cxample. So also the reduced and clevated hind toe of certain birds, the splint bones or rudimentary side toes of the horse, the rudimentary eyes of blind fishes, the minute barbel or beard of the hormed dace or chub, and the rudimentary teeth of the right whales and sword-fish. 
Each of these vestigial organs tells a story of some past adaptation to conditions, one that is no longer needed in the life of the species. They have the same place in the study of animals that silent letters have in the study of words. For cxample, in our word knight the $k$ and $g h$ are no longer sounded; but our ancestors used them both, as the Germans do to-day in their cognate word Finecht. So with the French word temps, which means time, in which both $p$ and $s$ are silent. 'The Romans, from whom the French took this word, needed all its letters, for they spelled and pronounced it tempus. In general, every silent letter in every word was once sounded. In like manner, every vestigial structure was once in use and helpful or necessary to the life of the animal which possessed it.

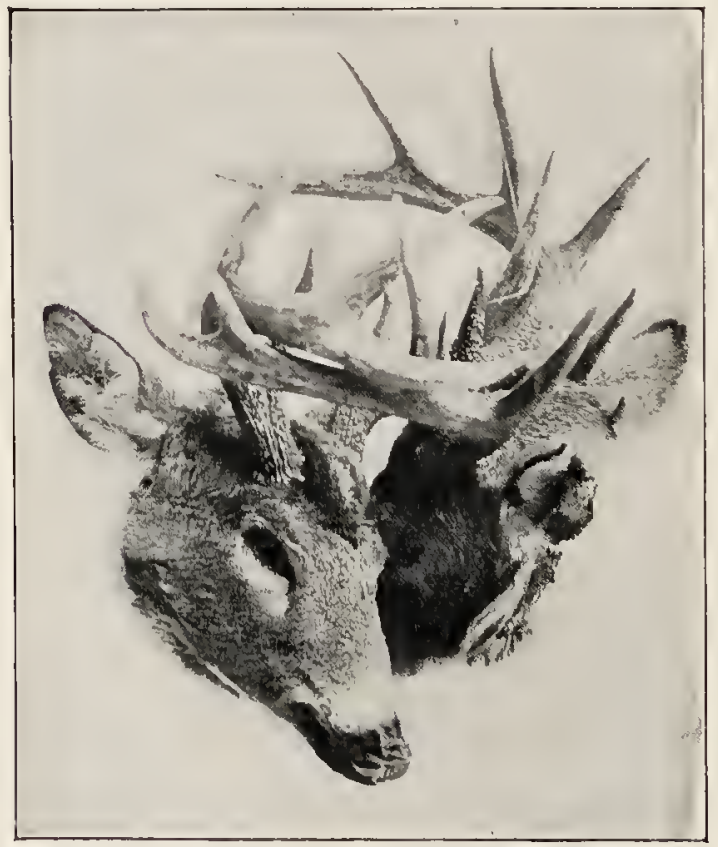

IIorns of two male alk interlocked while fighting. Permission of G. O. Sinfuns, publisher of Recreation. 


\section{CHAPTER IX}

\section{ANIMAL COMMUNITIES AND SOCIAL LIFE}

83. Man not the only social animal.-Man is eommonly called the social animal, but he is not the only onc to which this term may be applied. There are many others which possess a social or communal life. A moment's thought brings to mind the familiar faets of the communal life of the honey-bce and of the ants. And thcre are many other kinds of animals, not so well known to us, that live in communities or colonies, and live a life which in greater or less degree is eommunal or social. In this connection we may use the term communal for the life of those animals in which the division of labor is suel that the individual is depcndent for its continual existcnec on the community as a whole. 'The term social life would refer to a lower degree of mutual aid and mutual dependence.

84. The honey-bee.-Honcy-bees live together, as we know, in large eommunities. Wr arc accustomed to think of honey-bees as the inhabitants of bcc-hives, but there were bces before there werc hives. "The "bec-trec" is familiar to many of us. The becs, in Naturc, make their home in the lollow of some dead or deeaying tree-trunk, and carry on there all the industrics which characterize the busy communities in the hives. A honcy-bec community comprises threc kinds of individuals (Fig. 88)uamely, a fertile female or queen, numcrous males or drones, and many infertile femalcs or workers. These three kinds of individuals differ in external appearanee suffieiently to be readily recognizable. The workcrs are 
smaller than the queens and drones, and the last two differ in the shape of the abdomen, or hind body, the abdomen of the queen being longer and more slender than that of the
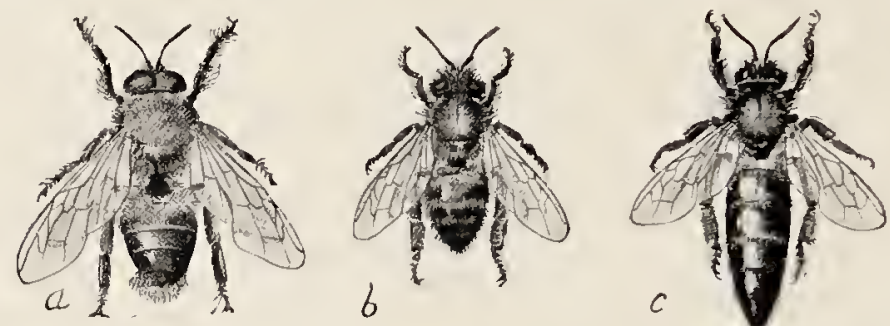

Fra. 88.-Iloney-bee. $a$, drone or male; $b$, worker or infertile female; $c$, queen or fertile female.

male or drone. In a single eommunity there is one queen, a few hundred drones, and ten to thirty thousand workers. The number of drones and workers varies at different times of the year, being smallest in winter. Each kind of individual has certain work or business to do for the whole community. The queen lays all the eggs from whieh new bees are born; that is, she is the mother of the entire commmity. The drones or males have simply to act as royal consorts; mpon them depends the fertilization of the eggs. 'The workers undertake all the food-getting, the care of the young bees, the comb-building, the honey-making - all the industries with which we are more or less familiar that are carried on in the hive. And all the work done by the workers is strietly work for the whole community; in no case does the worker bee work for itself alone; it works for itself only in so far as it is a nember of the community.

Iow varied and elaborately perfected these industries are may be pereeived from a brief account of the life history of a bee community. The interior of the hollow in the bee-tree or of the hive is filled with "comb" - that is, with wax molded into hexagonal cells and supports for these eells. The molding of these thousands of symmet- 
rical eells is accomplished by the workers by means of their speeially modified trowel-like mandibles or jaws. 'The wax itself, of whieh the eells are made, eomes from the bodies of the workers in the form of small liquid drops which exude from the skin on the under side of the abdomen or hinder body rings. These droplets run together, harden and become flattened, and are removed from the wax plates, as the peeuliarly modified parts of the skin which produce the wax are ealled, by means of the lind legs, which are furnished with scissor-like eontrivanees for entting off the wax (Fig. 89). In eertain of the eells arc stored the pollen and honey, which serve as food for the community. The pollen is gathered by the workers from eertain favorite flowcrs and is carricd by them from the flowers to the hive in the "pollen baskets," the slightly coneave outcr surfaces of one of the segments of the broadcned and flattened hind legs. This coneave surface is lined on each margin with a row of ineurved stiff hairs which hold the pollen mass securely in plaec (Fig. 89). The "loney" is the nectar of flowers which has been sueked up by the workers by means of their elaborate lapping and sucking mouth parts and swallowed into a sort of honey-sae or stomaeh, then brought to the hive and regurgitated into the

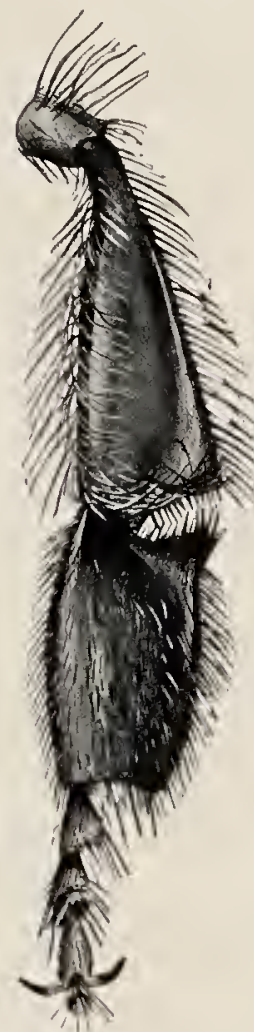

Fic. 89,-Posterior leg of worker loney-bce. The concave surface of the upper large joint with the marginal hairs is the polien basket; the wax shears are the cutting surfaces of the angle between the two large segments of the leg. eells. This neetar is at first too watery to be good honey, so the bees have to evaporate some of this water. Many of the workers gather above the eells containing 
nectar, and buzz - that is, vibrate their wings violently. This creates currents of air which pass over the exposed nectar and increase the evaporation of the ratel. 'The violent buzzing raises the temperature of the bees' bodies, and this warmth given off to the air also helps make eraporation morc rapid. In addition to bringing in food the workers also bring in, when necessary, "propolis," or the resinous gum of eertain trees, which they use in repairing the hive, as closing up eracks and creviees in it.

In many of the eells there will be found, not pollen or honey, but the eggs or the young bees in larval or pupal

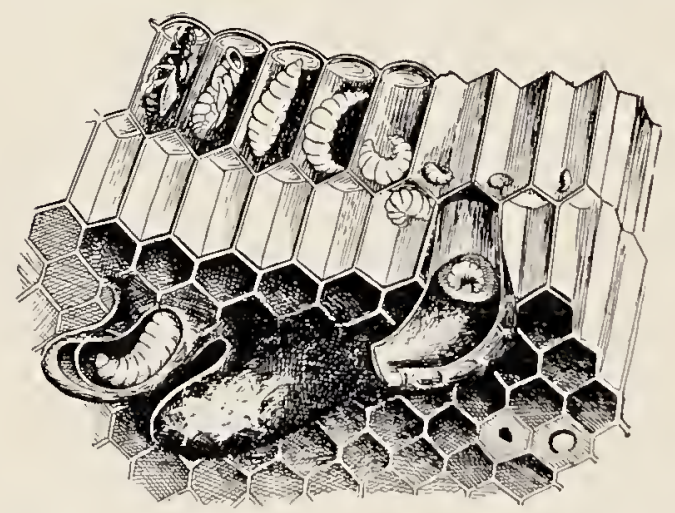

Fig. 90,-Cells containing eggs, larre, and pupie of the honey-bec. The fower large, irregular cells are queen cells.-After BENTON. condition (Fig. 90). The queen mores about through the hive, laying eggs. She deposits only one egr in a cell. In three days the egg hatehes, and the young bee appears as a helpless, soft, white, footless grub or larva. It is eared for by eertain of the workers, that may be called nurses. These nurses do not differ structurally from the other workers, but they have the speeial duty of caring for the helpless young bees. They do not go out for pollen or honey, but stay in the hive. They are usually the new bees-i. e., the youngest or most recently added workers. After they act as uurses for a week or so they take their platees with the food-gathering workers, and other new becs act as nurses. The nurses feed the young or larval bees at first with a highly nutritious food called bee-jelly, whieh the nurses make in their stomaeh, and regurgitate for the larvæ. After the larvæ are two or three days old 
they are fed with pollen and honey. Finally, a small mass of food is put into the eell, and the cell is "eapped" or coverer with wax. The larva, after eating all the food, in two or three days more ehanges into a pupa, whieh lies quiescent without eating for thirteen days, when it changes into a full-grown bee. The new bee breaks open the cap of the eell with its jaws, and comes out into the hive, ready to take up its share of the work for the community. In a few eases, however, the life history is different. The nurses will tear down several cells around some single one, and enlarge this inner one into a great irregular vase-shaped eell. When the egg hatehes, the grub or larva is fed beejelly as long as it remains a larva, never being given ordinary pollen and honey at all. This larva finally pupates, and there issues from the pupa not a worker or drone bee, but a new queen. The egg from which the queen is prodneed is the same as the other eggs, but the worker nurses by feeding the larva only the highly nutritious bee-jelly make it certain that the new bee shall beeome a queen instead of a worker. It is also to be noted that the male bees or drones are hatched from eggs that are not fertilized, the queen having it in her power to lay either fertilized or unfertilized eggs. From the fertilized eggs hateh larre which develop into queens or workers, depending on the manner of their nourishment; from the unfertilized eggs hatch the males.

When several queens appcar there is mueh excitement in the community. Eaeh community has normally a single one, so that when additional queens appear some rearrangement is necessary. This rearrangement comes about first by fighting among the queens until only one of the new queens is left alive. Then the old or mother queen issues from the hive or tree followed by many of the workers. She and her followers fly away together, finally alighting on some tree branch and massing there in a dense swarm. This is the familiar phenomenon of "swarming." The 
swarm finally finds a new hollow tree, or in the ease of the hive-bee (Fig. 91) the swarm is put into a new hive, where the bees build eells, gather food, prodnee young, and thus

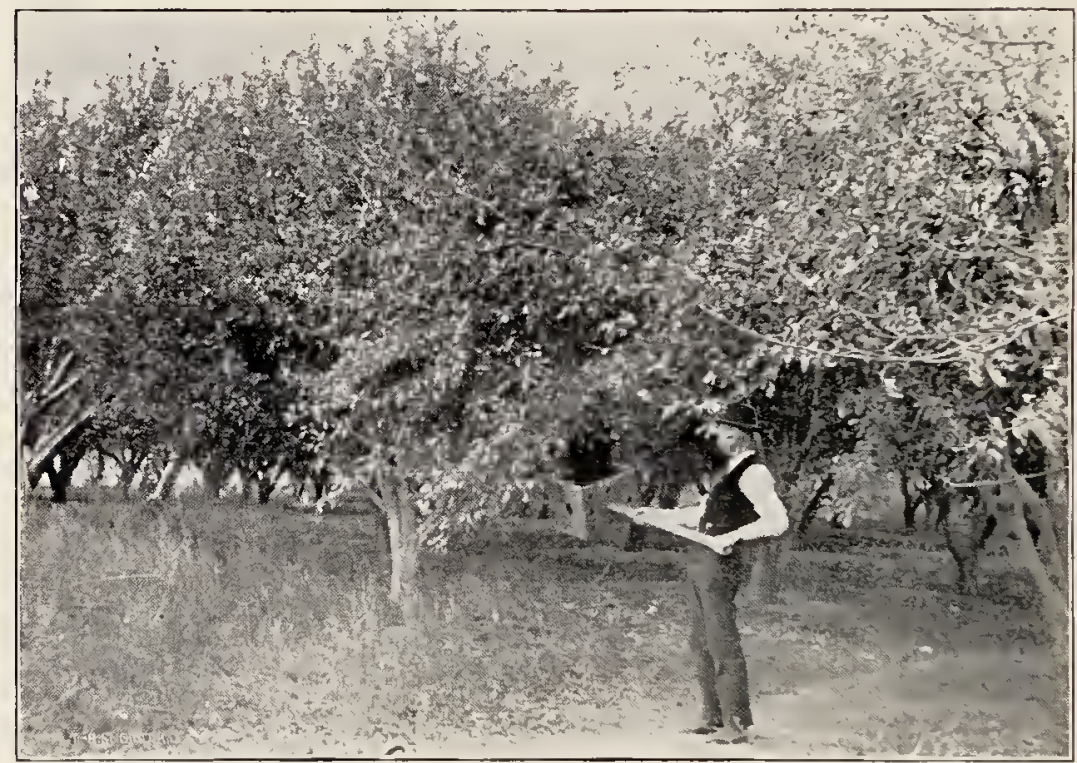

lit. 91.-1living a swarm of honey-bees. Photograph by 太. J. Huxter

found a new eommmity. This swaming is simply an emigration, which results in the wider distribution and in the inerease of the number of the speeies. It is a peculiar but effeetive mode of distributing and perpetuating the species.

'There are many other interesting and suggestive things whieh might be told of the life in a bee community : how the eommunity protects itself from the dangers of starvation when food is searee or winter comes on by killing the useless drones and the immatnre bees in egg and larval stage; how the instinct of home-finding has been so highly developed that the worker bees go miles away for honey and neetar, flying with nnerring aeenracy back to the hive; of the extraordinarily niee struetural modifieations whieh adapt the bee so perfeetly for its eomplex and varied businesses; and of the tireless persistenee of the workers until 
they fall exhausted and dying in the performance of their duties. The community, it is important to note, is a persistent or continuous one. The workers do not live long, the spring broods usually not over two or three months, and the fall broods not more than six or eight months; but new ones are hatching while the old ones are dying, and the community as a whole always persists. The queen may live several years, perhaps as many as fivc.* She lays about one million eggs a year.

85. The ants.-There are many speeies of ants, two thousand or more, and all of them live in communitics and show a truly eommunal life. There is mueh variety of habit in the lives of different kinds of ants, and the degree in which the communal or soeial life is speeialized or elaborated varies much. But certain gencral eonditions prerail in the life of all the differcnt kinds of individuals-
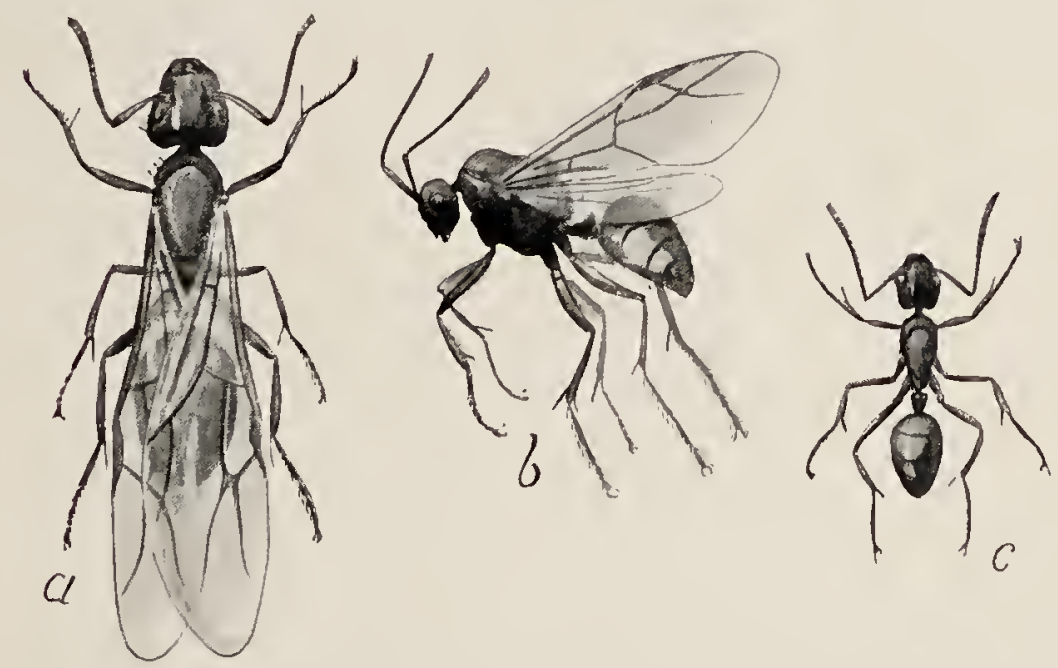

Fig. 92.-Female $(a)$, male $(b)$, and worker $(c)$ of an ant (Camponotus sp.).

sexually devcloped males and females that possess wings, and sexually undevcloped workers that are wingless (Fig. 92). In some kinds the workers show struetural differ-

* A queen bee has been kept alive in eaptivity for fifteen years. 
ences among themsclves, being divided into small workers, large workers, and soldiers. The workers are not, as with the bees, all infertile females, but they are both male and female, both being infertile. Although the life of the ant communities is much less familiar and fully known than that of the bees, it is even more remarkable in its specializations and elaborateness. The ant home, or nest, or formicary, is, with most species, a very elaborate underground, many-storied labyrinth of galleries and chambers. Certain rooms are used for the storage of food; certain others as "nurseries" for the reception and care of the young; and others as stables for the ants' cattle, certain plant-lice or scale-insects which are sometimcs collected and cared for by the ants. The food of ants comprises many kinds of vege. table and animal substances, but the favorite food, or "national dish," as it has bcen called, is a sweet fluid which is produced by certain small insects, the plant-lice (Aphidx) and scale-insects (Coccidx). These insects live on the sap of plants; rose-bushes are especially favored with their presence. The worker ants (and we rarely see any ants but the wingless workers, the winged males and females appearing out of the nest only at mating timc) find thesc honeysecreting insects, and gently touch or stroke them with their feelers (antennæ), when the plant-lice allows tiny drops of the honey to issuc from the body, which are calgcrly drunk by the ants. It is manifestly to the advantage of the ants that the plant-lice should thrive; but they are soft-bodicd, defenseless insects, and readily fall a prey to the wandering predaceous insects like the lady-birds and aphis lions. So the ants often guard small groups of plant-lice, attacking, and driving away the would-be raragers. When the branch on which the plant-lice are gets withered and dry, the ants have been observed to carry the plant-lice carefully to at fresh, green branch. In the Mississippi Valley a certain kind of plant-louse lives on the roots of corn. Its eggs are depositcd in the ground in the autumn and hatch 
the following spring before the eorn is planted. Now, the eommon little brown ant lives abundantly in the eornfields, and is speeially fond of the honey secreted by the corn-root plant-louse. So, when the plant-liee hateh in the spring before there are corn roots for them to feed on, the little brown ants with great solicitude carefully place the plant-lice on the roots of a eertain kind of knotweed whieh grows in the field, and protect them until the corn germinates. Then the ants remove the plant-lice to the roots of the eorn, their favorite food plant. In the arid lands of New Mexico and Arizona the ants rear their seale-inseets on the roots of cactus. Other kinds of ants earry plantliee into their nests and provide them with food there. Beeause the ants obtain food from the plant-lice and take care of them, the plant-liee are not inaptly called the ants' eattle.

Like the honey-bees, the young ants are helpless little grubs or larvæ, and are eared for and fed by nurses. The so-called ants' eggs, little white, oval masses, which we often see being earried in the mouths of ants in and out of an ants' nest, are not eggs, but are the pupæ whieh are being bronght out to enjoy the warmth and light of the sun or being taken baek into the nest afterward.

In addition to the workcrs that build the nest and eolleet food and eare for the plant-liee, there is in many specics of ants a kind of individuals called soldiers. These are wingless, like the workers, and are also, like the workers, not capable of laying or of fertilizing eggs. It is the business of the soldiers, as their name suggests, to figlit. They protect the community by attacking and driving away predaceous insects, especially other ants. The ants are among the most warlike of insects. The soldiers of a community of one species of ant often sally forth and attaek a community of some other speeies. If sueessful in battle the workers of the vietorious community take possession of the food stores of the conquered and earry 
them to their own nest. Indeed, they go even further; they may make slaves of the eonquered ants. There are numerous species of the so-called slave-making ants. The slavemakers carry into their own nest the eggs and larvæ and pupæ of the conquered eommunity, and when these come to maturity they act as slaves of the victors-that is, they collect food, build additions to the nests, and care for the young of the slave-makers. This specialization goes so far in the case of some kinds of ants, like the robber-ant of South Ameriea (Eciton), that all of the Eciton workers have beeome soldiers, which no longer do any work for themselves. The whole community lives, therefore, wholly by pillage or by making slaves of other kinds of ants. There are four kinds of individuals in a robber-ant eommunitywinged males, winged females, and small and large wingless soldiers. There are many more of the small soldiers than of the large, and some naturalists believe that the few latter, which are distinguished by heads and jaws of great size, act as officers. On the march the small soldiers are arranged in a long, narrow column, while the large soldiers are scattered along on either side of the eolumn and appear to act as sentinels and direetors of the army. The observations made by the famous Swiss students of ants, Ifuber and Forel, and by other naturalists, read like fairy tales, and yet are the well-attested and often reobserved actnal phenomena of the extremely specialized communal and social life of these animals.

86. Other communal insects.--The termites or white ants (not true ants) are communal insects. Some species of termites in Africa live in great mounds of earth, often fifteen feet high. The community comprises hundreds of thousinds of individuals, which are of eight kinds (Fig 93), viz., sexually aetive winged males, sexually aetive winged females, other fertile males and females which are wingless, wingless workers of both sexes not eapable of reproduetion, and wingless soldiers of both sexes also incapable of 
reproduction. The production of new individnals is the sole business of the fertile males and females; the workers build the nest and collect food, and the soldiers proteet the community from the attaeks of marauding inseets. The egg-laying queen grows to monstrous size, being sometimes
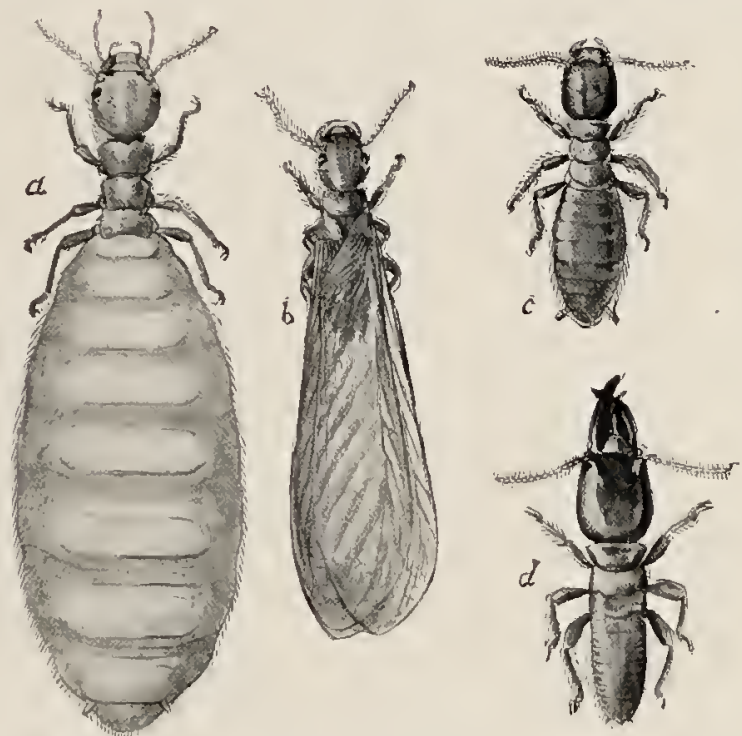

Fic. 93.-Termites. $a$, queen ; $b$, male; $c$, worker; $a$, soldier.

five or six inches long, while the other individnals of the community are not more than half or three quarters of an inch long. The great size of the queen is due to the enormous number of eggs in her body.

The bumble-bees live in commmities, but their social arrangements are very simple ones eompared with those of the honey-bee. There is, in fact, among the bees a series of gradations from solitary to commmnal life. 'The interesting little green carpenter-bees live a truly solitury life. Eaeh female bores ont the pith from five or six inches of an elder branch or raspberry cane, and divides this spaee into a few cells by means of transverse partitions (Fig. 94). In each cell she lays an egg, and puts with it enongh food -flower pollen-to last the grub or larva throngh its life. 
She then waits in an upper eell of the nest until the young bees issue from their eells, when she leads them off, and each begins aetive life on its own aceount. The mining-

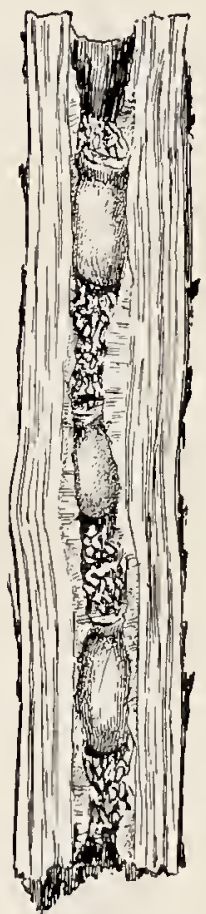

FIG. 94-Nest of carpenter-bee.

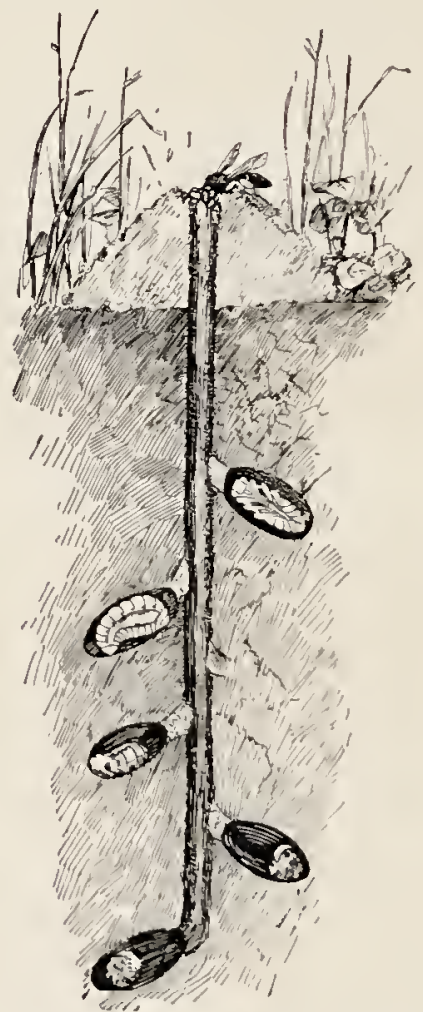

Fie. 95,-Nest of Andrena, the mining-bee.

bees (Andrenc), whieh make little burrows (Fig. 95) in a elay bank, live in large eolonies-that is, they make their nest burrows elose together in the same elay bank, but each female makes her own burrow, lays her own eggs in it, furnishes it with food-a kind of paste of neetar and pollenand takes no further eare of her young. Nor has she at any time any speeial interest in her neighbors. But with the smaller mining-bees, belonging to the genus Hutictus, several females unite in making a eommon burrow, after which each female makes side passages of her own, extend- 
ing from the main or public entranee burrow. As a wellknown entomologist has said, Andrena builds villages eomposed of individual homes, while Halictus makes eities composed of apartment houses. The bumble-bee (Fig. 96), however, establishes a real community with a truly communal life, although a very simple one. The few bumblebees which we see in winter time are queens; all other bumble-bees die in the autumn. In the spring a queen seleets some deserted nest of a field-mouse, or a hole in the ground, gathers pollen which she molds into a rather large irregular mass and puts into the hole, and lays a few eggs on the pollen mass. 'The young grubs or larvæ which soon hateh feed on the pollen, grow, pupate, and issue as workers-winged bees a little smaller than the quecu. These workers bring more pollen, enlarge the nest, and make irregular eells in the pollen mass, in each of which the qneen lays an egg. She gathers no more pollen, does no more work exeept that of egg-laying. From these new eggs are produeed more workers, and so on until the eommunity may come to be pretty large. Isater in the summer males and females are produced and mate. With the approach of winter all the workers and males die, leaving only the fertilized females, the queens, to live through the winter and found new eommunities in the spring.

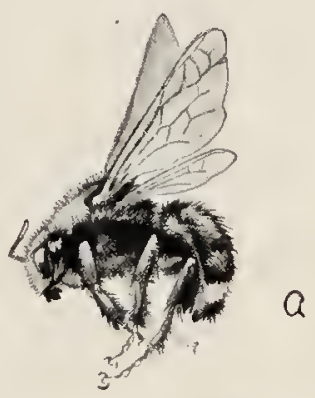

The social wasps show a communal life like that of the bumble-bees. 'The only yellow-jaekets and hornets that live through the winter are fertilized females or queens. 
When spring comcs each queen builds a small nest suspended from a tree branch, and consisting of a small comb inclosed in a covering or envelope open at the lower end. The nest is composed of "wasp paper," made by chewing bits of weather-beaten wood taken from old fences or outbuildings. In each of the cells the queen lays an egg. She deposits in the cell a small mass of food, consisting of some chewed insects or spiders. From these eggs hatch grubs which eat the food prepared for them, grow, pupate, and issne as worker bees, winged and slightly smaller than the queen (Fig. 9\%). The workers enlarge the nest, adding more combs and making many cells, in each of which the queen lays an egg. The workcrs provision the cell with chewed insects, and other broods of workers are

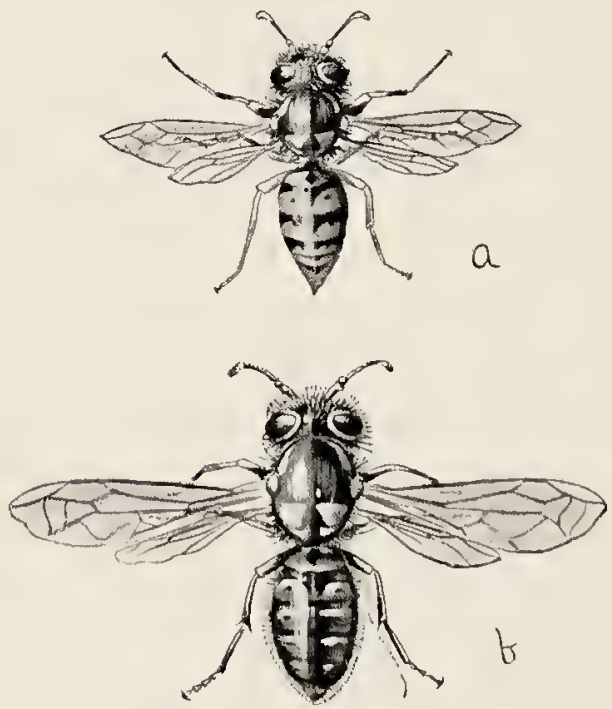

F1t. 97.-The yellow-jacket (Tespa), a social wasp. $a$, worker; $b$, queen. rapidly hatched. The community grows in numbers and the nest grows in size until it comes to be the great ball-like oval mass which we know so well as a hornets' nest (Figs. 98 and 99 ), a thing to be left mutouched. Sometimes the nest is built underground. Wh en disturbed, they swarm out of the hole and ficreely attack any invading foe in sight. After a number of broods of workers has bcen produccd, broods of males and females appear and mating takes place. In the latc fall the males and all of the many workers die, lcaving only the new queens to live through the winter. 
The bumble-bees and soeial wasps show an intermediate condition between the simply gregarious or neighborly

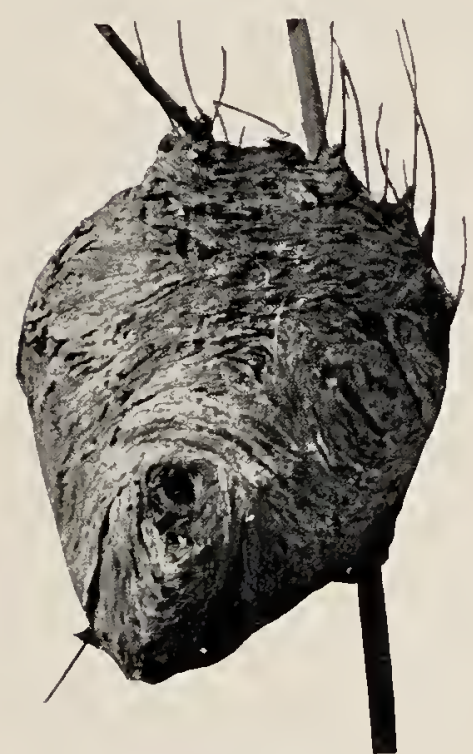

Fig. 98.-Nest of Tespa, a social wasp. From photograph.

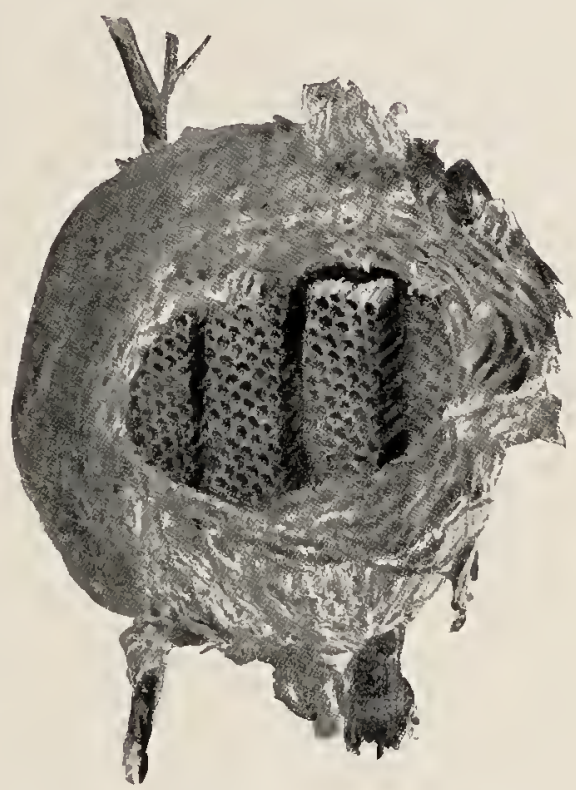

Fig. 99.-Nest of Vespa olvened to show combs within.

mining-bees and the highly developed, pcrmanent honeybee eommunity. Naturalists belicve that the highly organized communal life of the honcy-bees and the ants is a development from some simple eondition like that of the bumble-becs and soeial wasps, which in its turn has grown out of a still simpler, mere gregarious asscmbly of the individuals of one specics. It is not difficult to see how such a development eould in the course of a long time take place.

8\%. Gregariousness and mutual aid.-The simplest form of social life is shown among those kinds of animals in which many individuals of one species kcep together, forming a great band or herd. In this ease there is not mueh division of labor, and the safety of the individual is not wholly bound up in the fate of the herd. Sueh animals are 
said to be gregarious in habit. The habit undoubtedly is advantageous in the mutual protection and aid afforded the individuals of the band. This mutual help in the case of many gregarious animals is of a very positive and obvious character. In other cases this gregariousness is reduced to a matter of slight or temporary convenience, possessing but little of the element of mutual aid. The great herds of reindeer in the north, and of the bison or buffalo which once ranged over the Western American plains, are examples of a gregariousness in which mutual protection from enemies, like wolves, seems to be the principal advantage gained. The bands of wolves which hunted the buffalo show the advantage of mutual help in aggression as well as in protection. In this banding together of wolves there is active co-operation among individuals to obtain a common food supply. What one wolf can not do-that is, tear down a buffalo from the edge of the herd-a dozen can do, and all are gainers by the operation. On the other hand, the vast assembling of sea-birds (Fig. 100) on certain occan islands and rocks is a condition probably brought about rather by the special suitablcness of a few places for safe breeding than from any special mutual aid afforded; still, these seabirds undoubtedly combine to drive off attacking eagles and hawks. Eagles are usually considered to be strictly solitary in habit (the unit of solitarincss being a pair, not an individual); but the description, by a Russian naturalist, of the hunting habits of the great white-tailed cagle (Haliatos albicilla) on the Russian steppes shows that this kind of eagle at least has adopted a gregarious habit, in which nutual help is plainly obvious. This naturalist once saw an cagle high in the air, circling slowly and widely in perfect silence. Suddenly the cagle screamed loudly. "Its cry was soon answercd by another cagle, which approached it, and was followed by a third, a fourth, and so on, till nine or ten eagles came together and soon disappeared." The naturalist, following them, soon discovered them gathered 


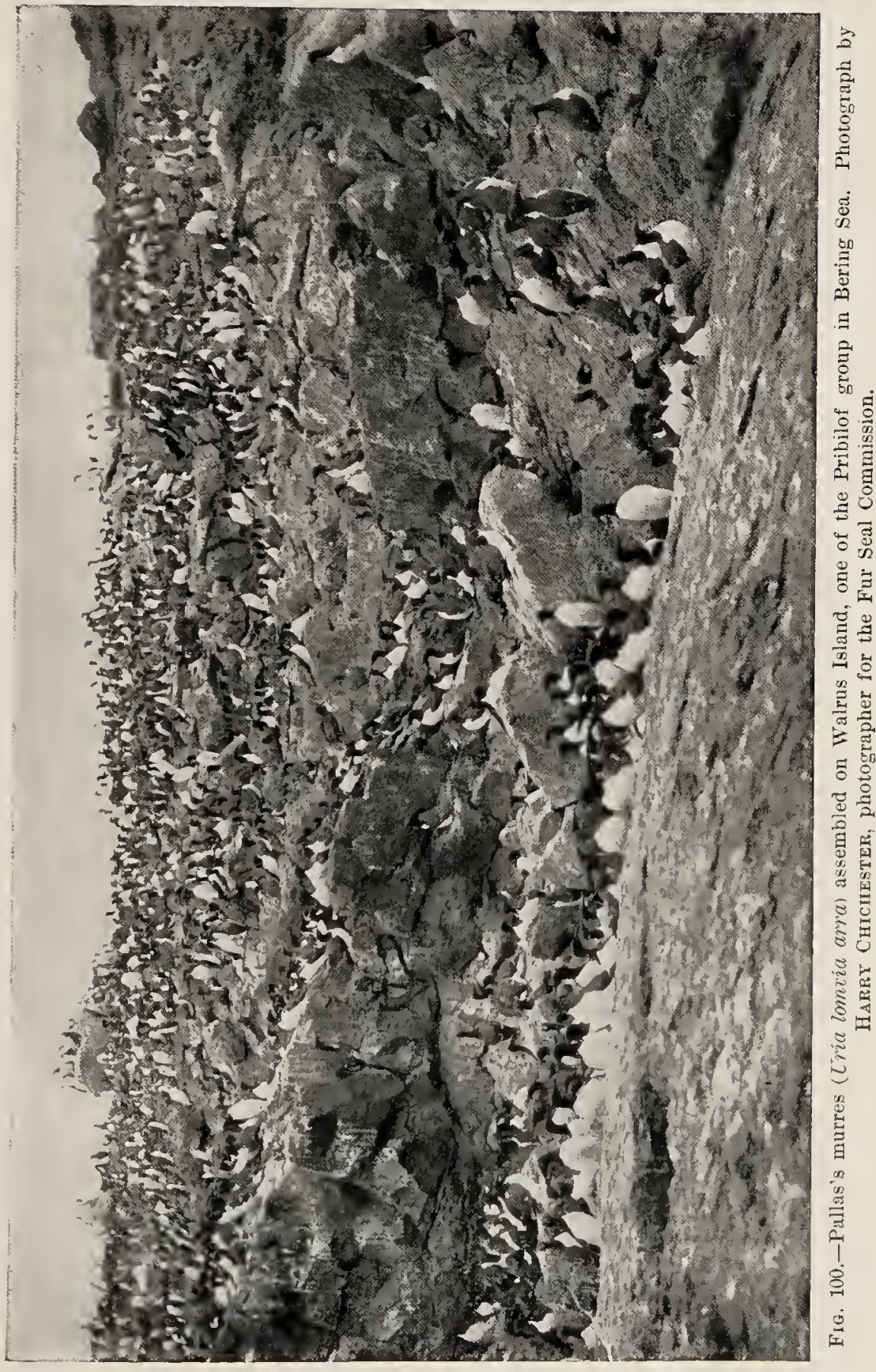


about the dead body of a horse. The food found by the first was being shared by all. The well-known assoeiation of pelieans in fishing is a good example of the adrantage of a gregarious and mutually helpful habit. The pelicans go fishing in great bands, and, after having chosen an appropriate place near the shore, they form a wide half-eirele facing the shore, and narrow it by paddling toward the land, eatehing the fish which they inclose in the erer-narrowing eircle.

The wary Rocky Mountain sheep (Fig. 101) live together in small bands, posting sentinels whenerer they are feeding or resting, who wateh for and give warning of the approach of enemies. The beavers furnish a wellknown and very interesting example of mutual help, and they exhibit a truly eommunal life, although a simple one. They live in "villages" or communities, all helping to build the dam across the stream, which is neeessary to form the broad marsh or pool in which the nests or houses are built. Prairie-dogs live in great rillages or communities which spread over many acres. They tell each other by shrill cries of the approach of enemies, and they seem to visit each other and to enjoy each other's society a great deal, although that they afford each other mueh aetual active help is not apparent. Birds in migration are gregarious, although at other times they may live comparatively alone. In their long flights they lieep together, often with definite leaders who seem to discover and deeide on the course of flight for the whole great flock. The wedgeshaped flocks of wild geese flying high and nttering their sharp, metallie call in their southward migrations are well known in many parts of the United States. Indeed, the more one studies the habits of animals the more examples of social life and mutual help will be found. Probably most animals are in some degree gregarious in habit, and in all cases of gregariousness there is probably some degree of mutual aid. 


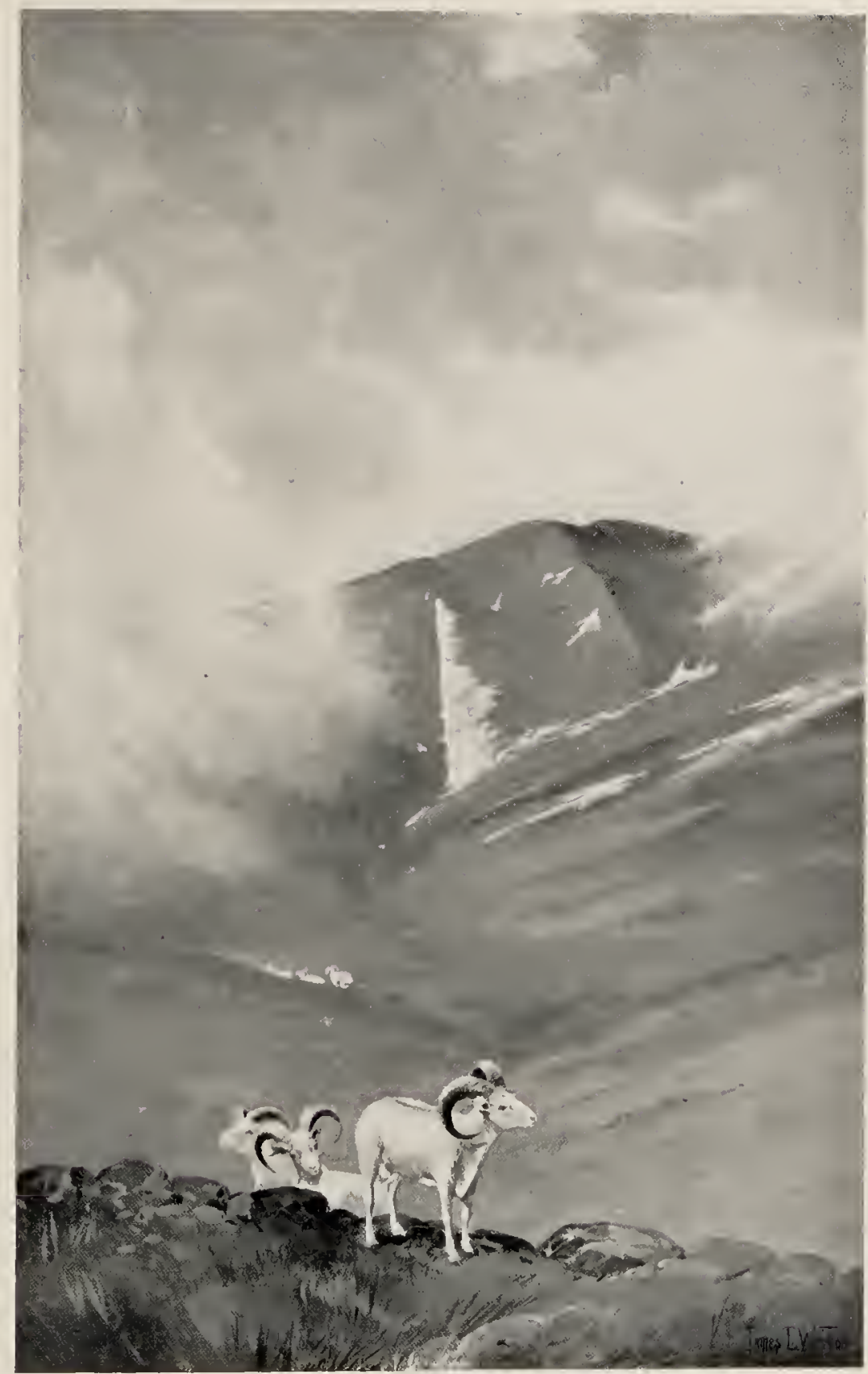

FIG. 101.-Rocky Mountain or highorn sheep. By permission of the publishers of Outing. 
88. Division of labor and basis of communal life.- TVe have learned in Chapters II and IV that the eomplexity of the bodies of the higher animals depends on a specialization or differentiation of parts, due to the assumption of different functions or duties by different parts of the body; that the degree of structural differentiation depends on the degree or extent of division of labor shown in the eeonomy of the animal. It is obvious that the same principle of division of labor with accompanying modifieation of structure is the basis of colonial and eommunal life. It is simply a manifestation of the principle among individuals instead of among organs. The division of the neeessary labors of life among the different zooids of the colonial jelly-fish is plainly the reason for the profound and striking, but always reasonable and explicable modifieations of the typieal polyp or medusa body, which is shown by the swimming zooids, the feeding zooids, the sense zooids, and the others of the colony. And similarly in the case of the termite community, the soldicr individuals are different structurally from the worker individuals beeause of the different work they have to do. And the queen differs from all the others, because of the cxtraordinary prolifieacy demanded of her to maintain the great eommunity.

It is important to note, however, that among those animals that show the most highly organized or specialized eommmnal or soeial life, the struetural differcnees among the individuals are the least marked, or at least are not the most profomd. The three kinds of honey-bec individuals differ lnt little; indeed, as two of the kinds, male and female, arc to be found in the case of almost all kinds of animals, whether commmal in habit or not, the only unusual structural specialization in the case of the honey-bee, is the presence of the worker individual, which differs from the nsual individuals in but little more than the rudimentary condition of the reproduetive glands. Finally, in the case of man, with whom the conmunal or soeial habit is so 


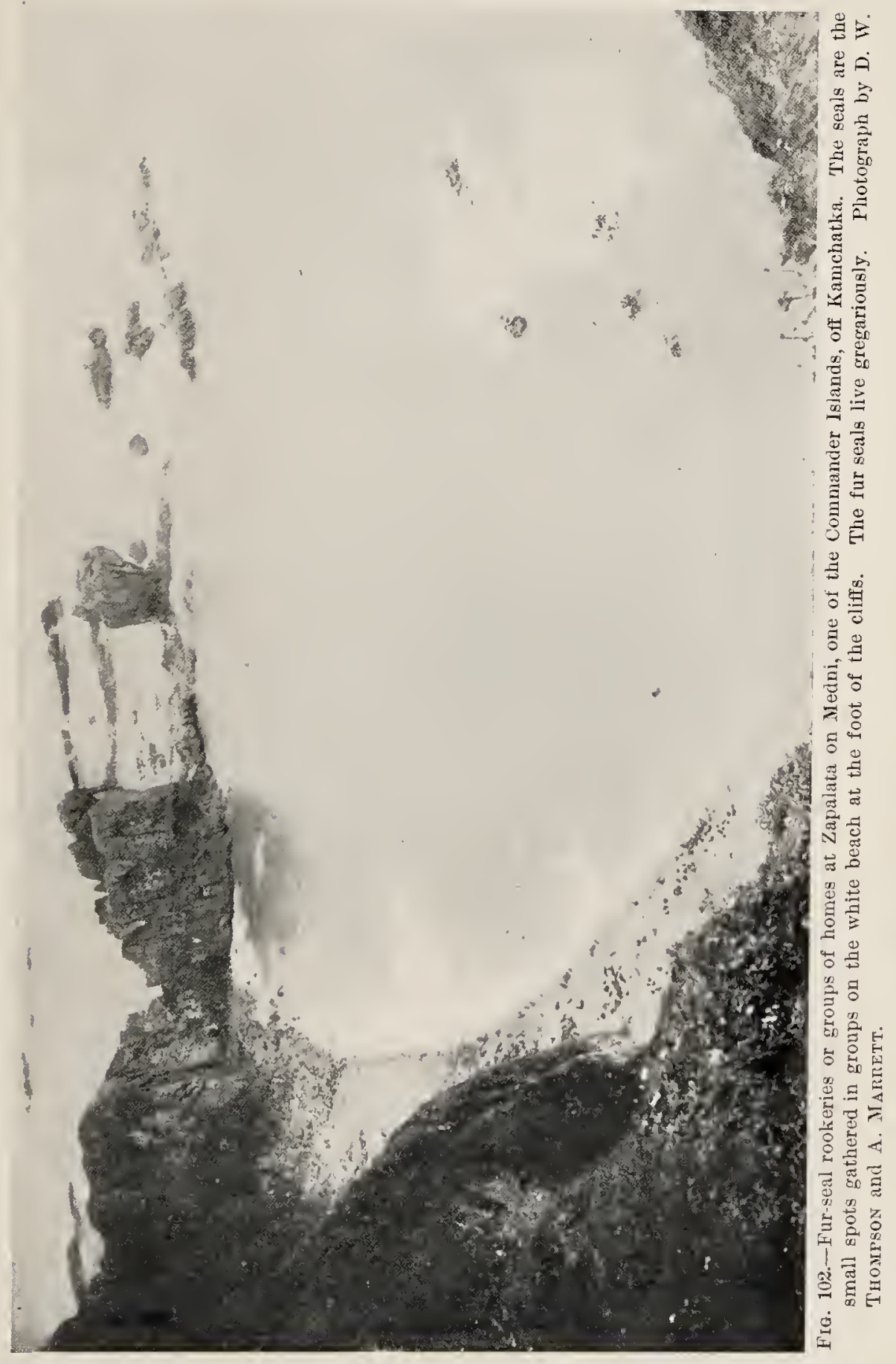


all-important as to gain for him the name of "the social animal," there is no differentiation of individuals adapted only for certain kinds of work. Among these highest examples of social animals, the presence of an adranced mental endowment, the specialization of the mental power, the power of reason, have taken the place of and made unnecessary the structural differentiation of individuals. The honey-bee workers do different kinds of work: some gather food, some care for the young, and some make wax and build cells, but the individuals are interchangcable; each one knows enough to do these various things. There is a structural differentiation in the matter of only one special work or function, that of reproduction.

With the ants there is, in some cases, a considerable structural divergence among individuals, as in the gcnus Atte of South America with six kinds of individualsnamely, winged males, winged females, wingless soldiers, and wingless workers of threc distinct sizcs. In the case of other kinds with quite as highly organized a commumal life there arc but three kinds of individuals, the winged males and females and the wingless workers. The workers gather food, build the nest, guard the "cattle" (aphids), make war, and carc for the young. Each onc knows enough to do all these various distinct things. Its body is not so modified that it can do but one kind of thing, which thing it must always do.

The increase of intelligence, the development of the power of reasoning, is the most potent factor in the development of a highly specialized social life. Nan is the example of the highest development of this sort in the animal kingdom, but the highest form of social devclopment is not by any means the most perfectly communal.

89. Advantages of communal life.-The advantages of communal or social life, of co-operation and mutual aid, are real. The animals that have adopted such a life are among the most successful of all animals in the struggle for exist- 
ence. The termite individual is onc of the most defenscless, and, for those animals that prey on insects, one of the most toothsome luxuries to bc found in the insect world. But the termite is one of the most abundant and widespread and successfully living insect kinds in all the tropics. Where ants are not, few insccts are. The honeybee is a popular typc of a successful lifc. The artificial protection afforded the honey-bee by man may aid in its struggle for existence, but it gains this protection because of certain features of its communal life, and in Nature the honey-bee takes care of itself wcll. The Littlc Bec People of Kipling's Jungle Book, who live in great communities in the rocks of Indian hills, can put to rout the largest and fiercest of the jungle animals. Co-operation and mutual aid arc among the most important factors which help in the struggle for cxistence. Its great advantages are, however, in some degrec balanced by the fact that inutual help brings mutual dependence. The community or socicty can accomplish greater things than the solitary individuals, but co-operation limits frecdom, and often sacrifices the individual to the whole. 


\section{CHAPTER X \\ COMMENSALISM AND SYMBIOSIS}

90. Association between animals of different species.-The living together and mutual help discussed in the last chapter concerned in each instance a single species of animal. All the various members of a pack of wolves or of a community of ants are individuals of the same species. But there are many instances of an association of indiriduals of different kinds of animals. The number of individuals concerned, however, is usually but two-that is, one of each of the two kinds of animals. In many cases of an association of individuals of different specics one kind derives great benefit and the other suffers more or less injury from the association. Onc kind lives at the expense of the other. This association is called parasitism, and is discussed in the next chapter. In some cases, howcrer, neither kind of animal suffers from the presence of the other. 'The two live together in harmony and presumably to their mutual advantage. In some cases this mutual alvantage is obvious. This kind of association is called commensulism or symbiosis. The term commensalism may be used to denote a condition where the two animals arc not so intimately associated nor derive such obvious mutual adrantage from the association, as in that condition of very intimate and permanent association with obvious co-operative and marked advantage that may be called symbiosis. A few examples of each of thesc interesting conditions of association between which it is impossible to make any sharp distinction, will be given. 
91. Commensalism.-A eurious example of eommensalism is afforded by the different speeies of Remoras (Echenidide) whieh attaeh themselves to sharks, barraeudas, and other large fishes by means of a sueking disk on the top of the head (Fig. 103). This disk is made by a modifieation of

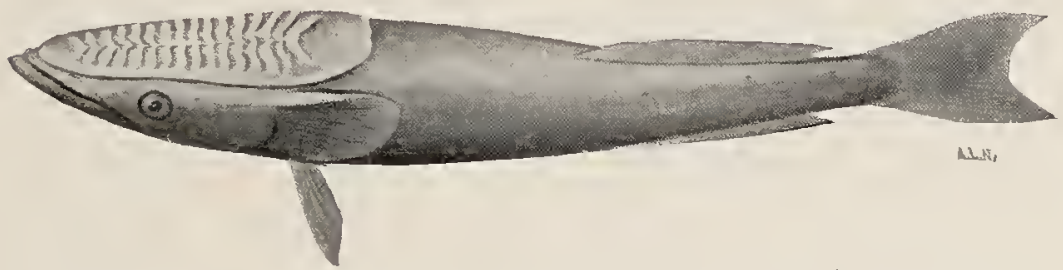

Fig. 103.-Remora, with dorsal fin modified to be a sucking plate by which the fish attaches itself to a shark.

the dorsal fin. The Remora thus attached to a shark may be earried about for weeks, leaving its host only to secure food. This is done by a sudden dash through the water. The Remora injures the shark in no way save, perhaps, by the slight eheek its presenee gives to the shark's speed in swimming.

Whales, similarly, often earry barnaeles about with them. These barnaeles are permanently attaehed to the skin of the whale just as they would be to a stone or wooden pile. Nany small erustaeeans, amnelids, mollusks, and other invertebrates burrow into the substanee of living sponges, not for the purpose of feeding on them, but for shelter. On the other hand, the little boring sponge (Ctiona) burrows in the shells of oysters and other bivalves for protection. These are hardly true eases of even that lesser degree of mutually advantageous assoeiation whieh we are ealling eommensalism. But some speeies of sponge "are never found growing exeept on the baeks or legs of eertain erabs." In these eases the sponge, with its many plant-like branehes, proteets the erab by eoneealing it from its enemies, while the sponge is benefited by being earried about by the erab to new food supplies. Certain sponges 
and polyps are always found growing in close association, though what the mutual advantage of this association is has not yet been found out.

Among the coral reefs near Thursday Island (between New Guinea and Australia) there lives an enormous kind of sea-anemone or polyp. Individuals of this great polyp measure two feet across the disk when fully expanded. In the interior, the stomach eavity, which communicates freely with the outside by means of the large mouth opening at the free end of the polyp, there may often be found a small fish (Amphiprion percula). That this fish is purposely in the gastral eavity of the polyp is proved by the faet that when it is dislodged it invariably returns to its singular lodging-place. The fish is brightly colored, being of a brilliant vermilion hue with three broad white cross bands. The diseorerer of this peeuliar habit suggests that there are mutual benefits to fish and polyp from this habit. "The fish being conspienous, is liable to attacks, which it escapes by a rapid retreat into the sea-anemone; its enemies in hot pursuit blunder against the outspread tentacles of the ancmone and are at once nareotized by the 'thread cells' shot out in imnumerable showers from the tentacles, and afterward drawn into the stomach of the anemone and digested."

Small fish of the genus Nomers may often be found accompanying the beantiful Portuguese man-of-war (Physalia) as it sails slowly about on the ocean's surfaec (Fig. 104). These little fish lurk undermeath the float and among the various hanging thread-like parts of the Physatia, which are provided with stinging cells. The fish are protected from their enemies by their proximity to these stinging threads, but of what advantage to the man-ofwar thcir prescnee is is not understood. Similarly, several kinds of medusa are known to harbor or to be aceompanied by young or small adult fishes.

In the nests of the varions species of ants and termites 
many different kinds of other inseets have been found. Some of these are harmful to their hosts, in that they feed on the food stores gathered by the industrious and provident ant, but other's appear to feed only on refuse or useless substances in the nest. Some may even be of help to their hosts. Over one thonsand species of these myrmeeophilous (aut-loving) and termitophilous (termite-loving) insects have been recorded by eollectors as living habitually in the nests of ants and termites. 'The owls and rattlesnakes whieh live with the prairie-dogs in their villages afford a familial example of eommensalism.

92. Symbiosis. - Of a more intimate charaeter, and of more obvious and certain mutual advantage, is the wellknown case of the symbiotic assoeiation of some of the numerous speeies of hermitcrabs and eertain specics of sea-anemones. The hermiterab always takes for his habitation the shell of another animal, often that of the eommon whelk. All of

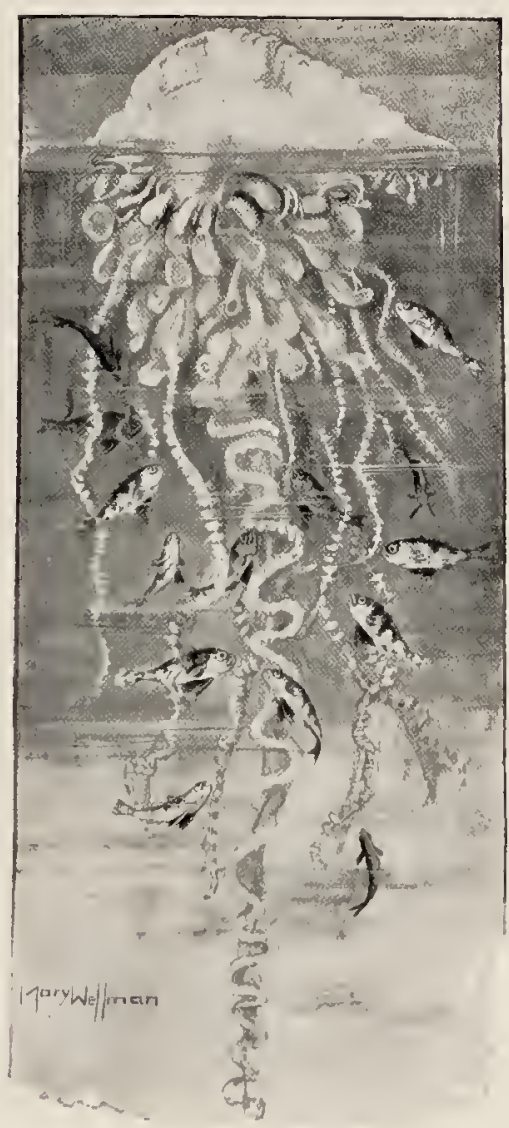

Fia. 104.-A Portuguese man-of-war (Physolia), with man-of-war fishes (Nomeus gronovii) living in the shelter of the stinging feelers. speeimens from off Tampa, Nla.

the hind part of the erab lies inside the shell, while its head with its great elaws project from the opening of the shell. On the surface of the shell near the opening there is usually to be found a sea-ancmone, or sea-rose (Fig. 105). 
This sea-anemone is fastened seeurely to the shell, and has its mouth opening and tentaeles near the head of the erab. The sea-anemone is earried from plaee to plaee by the hermit-erab, and in this way is mueh aided in obtaining food. On the other hand, the erab is proteeted from its enemies by the well-armed and dangerous tentaeles of the sea-anem-

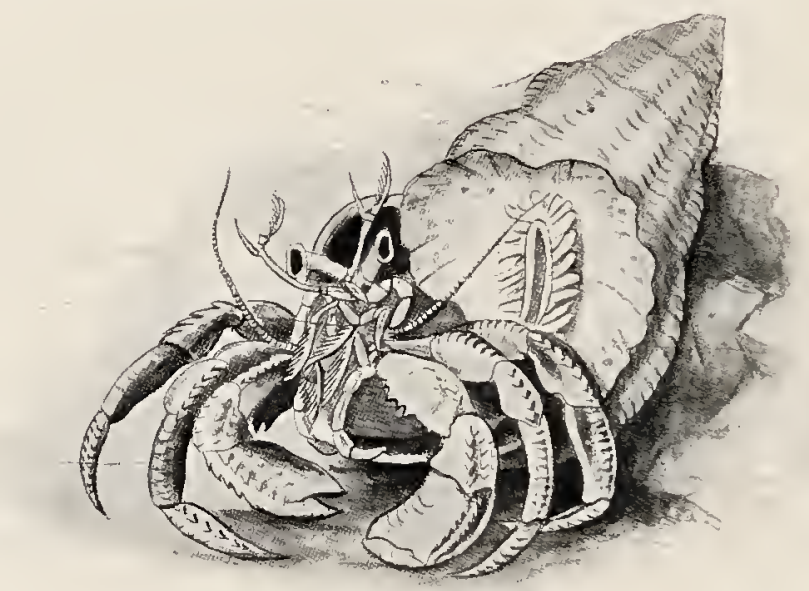

Fra. 105.-Hermit-crab (Pagume) in shell, with a sea-anemone (Adamsia palliata) attached to the shell.-After Hentwia.

one. In the tentaeles there are many thousand long, slender stinging threads, and the fish that would obtain the hermit-erab for food must first deal with the stinging anemone. There is no doubt here of the mutual adrantage gained by these two widely different but intimately assoeiated eompanions. If the sea-anemone be torn away from the shell inliabited by one of these erabs, the erab will wander about, carefully seeking for another anemone. When he finds it he struggles to loosen it from its roek or from whatever it may be growing on, and does not rest until he has torn it loose and plaeed it on his shell.

There are numerous small erabs ealled pea-erabs (Pinnotheres) whieh live habitually inside the shells of living 
mussels. The mussels and the erabs live together in perfeet harmony and to their mutual benefit.

Therc are a few cxtrcmely interesting eases of symbiosis in which not different kinds of animals are eoneerued, but animals and plants. It has long been known that some sea-anemones possess eertain body cells whieh contain chlorophyll, that green substance characteristic of the grcen plants, and only in few eases posscssed by animals. When thcse chlorophyll - bear in g sea-anemones wcre first found, it was believed that the chlorophyll cells really belonged to the animal's body,

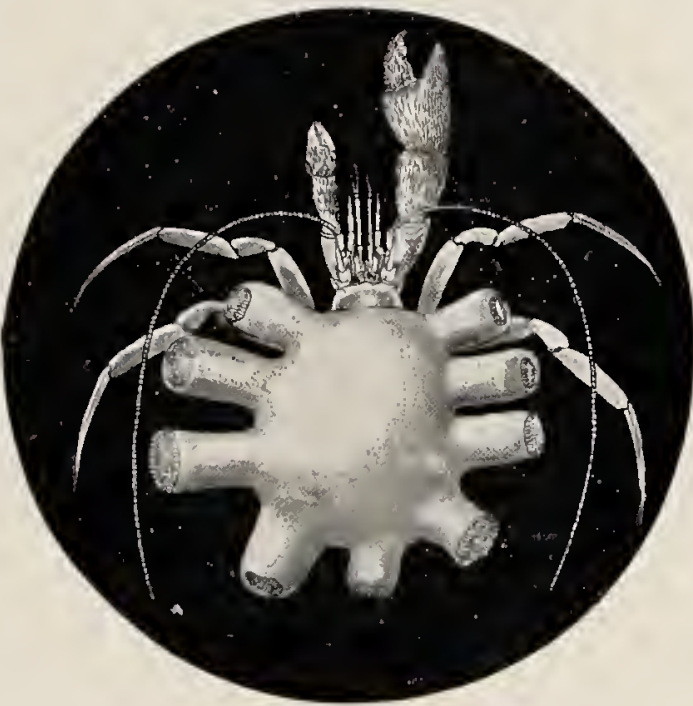

FIf, 106.-The crab Epizoanthus paguriphitus, with the sea-anemone Purapagumes pilosiramus on its shell. and that this eondition broke down one of the chicfest and most readily apparent distinetions between animals and plants. But it is now known that these chlorophyll-bearing cells are microseopic, one-celled plants, green algæ, which live habitmally in the bodies of the sea-ancmonc. It is a ease of true symbiosis. The algx, or plants, nse as food the earbonie-aeid gas whieh is given off in the respiratory proccsses of the sea-anemonc, and the sea-anemonc breathes in the oxygen given off by the algæ in the proeess of extracting the earbon for food from the earbonic-aeid gas. These algæ, or one-celled plants, lic regularly only in the innermost of the thrce cell layers which compose the wall 
or body of the sca-ancmone (Fig. 10\%). They penctrate into and lie in the interior of the eells of this layer whose spccial funetion is that of digestion. They give this innermost layer of cells

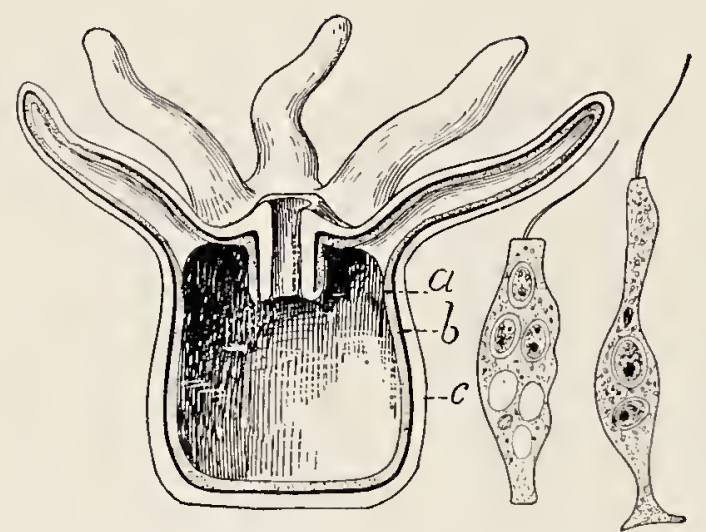
a distinct green color.

Therc are othcr examples known of the symbiotic association of plants and animals; and if we werc to follow the study of symbiosis into the plant kingdom we

FIG. 10\%.-Diagrammatic section of sea-anemone. $a$, the immer cell layer containing alga cells, the two isolated cells at right being cells of this layer with contained algae; b, middle body wall layer; $c$, outer body wall layer.-After IIEeTwit. should find that in one of the large groups of plants, the familiar liehens whieh grow on rocks and tree trunks and old fenees, crery member lives symbiotieally. A lichen is not a single plant, but is always composed of two plants, an alga (chlorophyll-bearing) and a fungus (without chlorophyll) living together in a most intimate, mutually advantageons assoeiation. 


\section{CHAP'TER XI}

\section{PARASITISM AND DEGENERATION}

93. Relation of parasite and host.-In addition to the various ways of living together of animals already deseribed, namely, the social life of individuals of a single species and the commensal and symbiotic life of individuals of different speeies, there is another kind of association among animals that is very coinmon. In cases of symbiosis the two animals living together are of mutual advantage to each other; both profit by the association. But tnere arc many instanees in the animal kingdom of an assoeiation betwecu two animals by which onc gains advantages great or small, sometimes even obtaining all the necessities of life, while the other gains nothing, but suffers corresponding disadvantage, often cren the loss of life itself. This is the association of parasite and host; the relation between two animals whereby one, the parasite, lives on or in the other, the host, and at the cxpense of the host. Parasitism is a common phenomenon in all gromps of animals, although the parasites themsclves are for the most part confined to the classes of invertcbrates. Among the simplest animals or Protozoa there are parasites, as Gregarina, which lives in the bodies of insects and crustaceans; there are parasitic worms, and parasitic erustaceans and mollusks and insects, and a fow vertebrates. When an animal can get along more safely or more easily by living at the expense of some other animal and takes 1 p sueh a lifo, it bccomes a parasite. Parasitism is naturally, therefore, not eonfined to any one group or class of animals. 
94. Kinds of parasitism.-The bird-lice (Nallophaga), which infest the bodies of all kinds of birds and are found especially abundant on domestie fowls, live upon the outside of the bodies of their hosts, feeding upon the feathers and dermal seales. They are examples of extemal purasites. Other examples are fleas and ticks, and the erustaceans ealled fish-lice and whale-lice, which are attached to marine animals. On the other hand, almost all animals are infested by certain parasitic worms which live in the alimentary canal, like the tape-worm, or imbedded in the museles, like the trichina. 'These are examples of internal parasites. Such parasites belong mostly to the class of worms, and some of them are very injurious, sucking the blood from the tissues of the host, while others feed solely on the partly digested food. There are also parasites that live partly within and partly on the ontside of the body, like the Sacculina, which lives on various kinds of crabs. The body of the Sacculina eonsists of a soft sac which lies on the ontside of the erab's body, and of a number of long, slender root-like processes which penetrate deeply into the crab's body, and take up nourishment from within. The Sacculina is itself a clustacean or erab-like creature. The classification of parasites as external and internal is purely arbitrary, but it is often a matter of convenience.

Some parasites live for their whole lifetime on or in the body of the host, as is the case with the bird-liee. Their eggs are laid on the feathers of the bird host; the young when hatehed remain on the bird during growth and development, and the adnlts only rarely leave the body, usually never. These may be called permanent parasites. On the other hand, fleas leap off or on a dog as eapriee dictates; or, as in other cases, the parasite may pass some definite part of its life as a free, non-parasitic organism, attaching itself, after development, to some animal, and remaining there for the rest of its life. These parasites may be ealled temporary parasites. But this grouping or elassification, 
like that of the external and internal parasites, is simply a matter of eonvenienee, and does not indieate at all any blood relationship among the members of any one group.

95. The simple structure of parasites. - In all eases the body of a parasite is simpler in strueture than the body of other animals whieh are elosely related to the parasitethat is, animals that live parasitieally have simpler bodies than animals that live free aetive lives, eompeting for food with the other animals about them. This simplieity is not primitive, but results from the loss or atrophy of the struetures which the mode of life renders useless. Many parasites are attaehed firmly to their host, and do not move about. 'They have no need of the power of locomotion. They are earried by their host. Such parasites are usually without wings, legs, or other loeomotory organs. Beeause they have given up loeomotion they have no need of organs of orientation, those speeial sense organs like eyes and ears and feelers which serve to guide and direet the moving animal; and most non-loeomotory parasites will be found to have no eyes, nor any of the organs of special sense whieh are aecessory to loeomotion and which serve for the detection of food or of enemies. Because these important organs, which depend for their suecessful aetivity on a highly organized nervous system, are lacking, the nervous system of parasites is usually very simple and undeveloped. Again, beeause the parasite usually has for its sustenance the already digested lighly nutritious food elaborated by its host, most parasites have a very simple alimentary eanal, or even no alimentary canal at all. Finally, as the fixed parasite leads a wholly sedentary and inaetive life, the breaking down and rebuilding of tissue in its body go on very slowly and in minimmm degree, and there is no need of highly developed respiratory and eireulatory organs; so that most fixed parasites have these systems of organs in simple eondition. Altogether the body of a fixed, permanent parasite is so simplified and so want- 
ing in all those special structures which characterize the higher, active, complex animals, that it often presents a very different appearance from those animals with which we know it to be nearly related.

The simplicity of parasites does not indicate that they all belong to the groups of primitive simple animals. Parasitism is found in the whole range of animal life, from primitive to highest. 'Their simplicity is something that has resulted from their mode of life. It is the result of a change in the body-structnre which we can often trace in the development of the individnal parasite. Many parasites in their young stages are free, active animals with a better or more complex body than they possess in their fully developer or adult stage. The simplicity of parasites is the result of degeneration-a degeneration that has been brought about by their adoption of a sedentary, non-competitive parasitic life. And this simplicity of degeneration, and the simplicity of primitireness should be sharply distinguished. Animals that are primitively simple have had only simple ancestors; aninials that are simple by degeneration often have had highly organized, complex ancestors. And while in the life history or development of a primitively simple animal all the young stages are simpler than the adult, in a degenerate animal the young stages may be, and usually are, more complex and more highly organized than the adult stage.

In the examples of parasitism that are described in the following pages all these general statements are illnstrated.

96. Gregarina.-In the intestines of cray-fishes, centipeds, and several kinds of insects may often be found certain one-celled animals (Protozoa) which are living as parasites. Their food, which they take into their minnte body by absorption, is the intestinal flnids in which they lie. These parasitic Protozoa belong to the genus Gregarina (Fig. 9) (see Chapter 1). Because the body of any 
protozoan is as simple as an animal's body ean bc, being eomposed of but a single eell, degeneration ean not occur in the eases of these parasites. There are, besides Gregarina, numerous other parasitie one-eelled animals, several kinds living inside the cells of their host's body. One kind lives in the blood-eorpuseles of the frog, and another in the eells of the liver of the rabbit.

9\%. The tape-worm and other flat-worms,-In the great group of flat-worms (Platyhelminthes), that group of animals which of all the prineipal animal groups is widest in its distribution, perhaps a majority of the species are parasites. Instead of bcing the exeeption, the parasitie life is the rulc among these worms. Of the thrce classes into which the flat-worms are divided almost all of the members of two of the classes are parasitcs. The common tapc-worm (Tania) (Fig. 108), whieh lives parasitically in the intestinc of man, is a good example of one of thesc elasscs. "It has the form of a narrow ribbon, which may attain the length of screral yards, attaehed at onc end to the wall of the intestinc, the remainder hanging frcely in the interior." Its body is eomposed of segments or serially

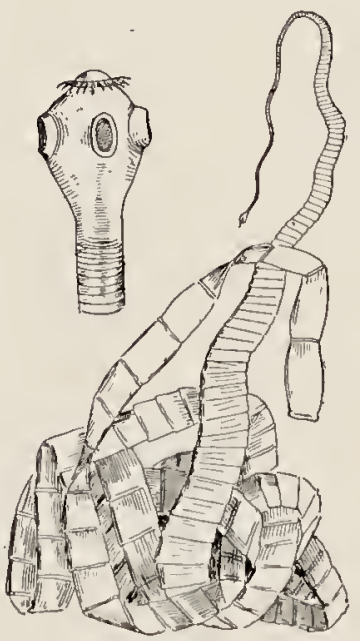

Fıa. 108.-Tape-worm (Tunia solium). In upper lefth..nd corner of figure the head much magnified. After LeUCKART. arranged parts, of whieh there are about eight hundred and fifty altogether. It has no mouth nor alimentary eanal. It feeds simply by absorbing into its body, through the surface, the nutritions, alrcady digested liquid food in the intestine. There are no eycs nor other speeial sensc organs, nor any organs of locomotion. The body is rery degeneratc. The life history of the tape-worm is interesting, because of thc neeessity of 
two hosts for its eompletion. 'The eggs of the tape-worm pass from the intestine with the excreta, and must be taken into the body of some other animal in order to develop. In the ease of one of the several speeies of tapeworms that infest man this other host must be the pig. In the alimentary canal of the pig the young tape-worm develops, and later bores its way through the walls of the eanal and beeomes imbedded in the muscles. There it lies, until it finds its way into the alimentary canal of man by his eating the flesh of the pig. In the intestine of man

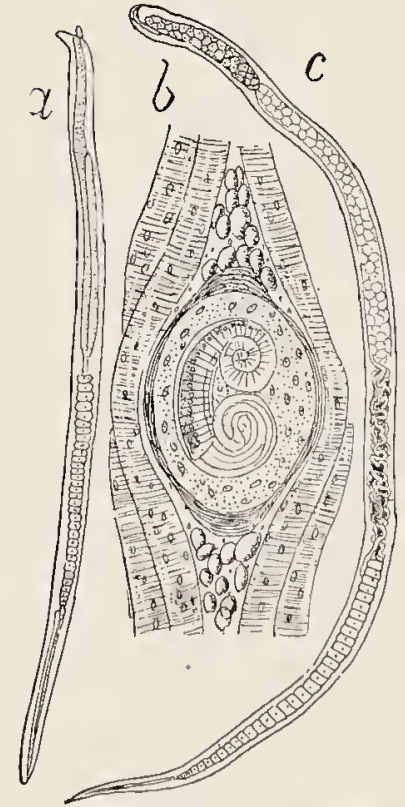

lise. 109. - Thiblima spirclis (after $C_{\perp \wedge U A}$. $a$, male; $b$, encysted form in muscle; $c$, formale. the tape-worm continues to develop until it becomes full grown.

In a lake in Yellowstone Park the suckers are infested by one of the flat-worms (Ligula) that attains a size of nearly one fourth the size of the fish in whose intestines it lives. If the tape-worm of man attained such a comparatire size, a man of two hmodred ponnds' weight would be infested by a parasite of fifty pounds' weight.

98. Trichina and other roundworms.-Another gromp of animals, nany of whose numbers are parasites, are the romnd-worms or threadworms (Nemathelminthes). The free-living round-worms are aetive, well-organized animals, but the pillasitic kinds all show a greater or less degree of degeneration. One of the most terrible parasites of man is a round-worm ealled Trickina spiratis (Fig. 109). It is a minnte worm, from one to three millimetres long, which in its adult eondition lives in the intestine of man or of the pig or other mammals. The young are born alive and bore through the walls 
of the intestine. They migrate to the roluntary muscles of the hosts, especially those of the limbs and back, and here each worm coils itself up in a muscle fiber and becomes inclosed in a spindle-shaped eyst or cell (Fig. 109, b). A single muscle may be infested by hundreds of thousands of these minute worms. It has been estimated that fully one hundred million encysted worms have existed in the muscles of a "trichinized" human body. The museles undergo more or less degeneration, and the death of the host may oceur. It is neeessary, for the further development of the worms, that the flesh of the host be eaten by another mammal, as the flesh of the pig by man, or the flesh of man by a pig or rat. The Trichine in the alimentary canal of the new host develop into aetive adult worms and produee new young.

In the Yellowstone Lake the trout are infested by the larvæ or young of a round-worm (Bothriocephalus cordiceps) which reaches a length of twenty inehes, and which is often found stitched, as it were, through the viscera and the muscles of the fish. The infested trout become feeble and die, or are eaten by the pelicans whieh fish in this lake. In the alimentary eanal of the peliean the worms become adult, and parts of the worms containing eggs escape from the alimentary eanal with the excreta. 'These portions of worms are eaten by the trout, and the eggs give birth to new worms which develop in the bodies of the fish with disastrous effeets. It is estimated that fol ach pelican in Yellowstone Lake over five million egrgs of the parasitic worms are discharged into the lake.

The young of various carnivorous animals are often infested by one of the species of round-worms called "pupworms" (Tneinaria). Recent investigations show that thousands of the young or pup fur-seals are destroyed each year by these parasites. The eggs of the worm lie through the winter in the sands of the breeding grounds of the furseal. The young reeeive them from the fur of the mother 


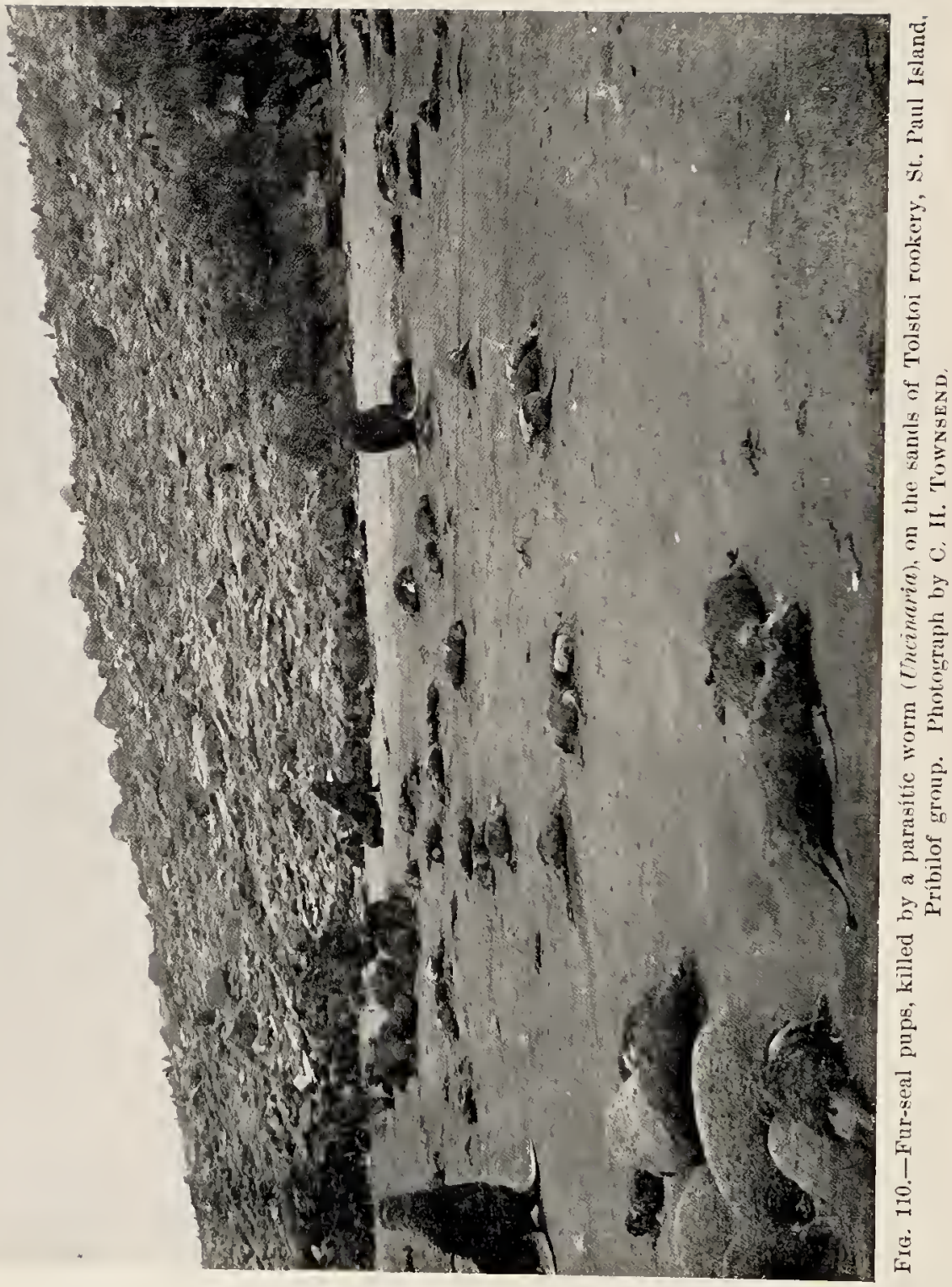


and the worm develops in the upper intestine. It feeds on the blood of the young seal, which finally dies from anæmia. On the beaches of the seal islands in Bering Sea there are sometimes hundreds of dead seal pups which have been killed by this parasite (Fig. 110).

99. Sacculina.-Among the more highly organized animals the results of a parasitie life, in degree of struetural degeneration, can be more readily seen. A well-known parasite, belonging to the erustacea- the elass of shrimps, erabs, lobsters, and cray-fishes-is Sarculina. The young Sacculina is an aetive, free-swimming larra mueh like a young prawn or young erab. But the adnlt bears absolutely no resemblanee to sueh a typical crustacean as a eray-fish or crab. The Sacculina after a short period of independent existence attaches itself to the abdomen of a e r a b, a u d there completes its development while living as a parasite. In its adult condition (Fig. 111) it is simply a great tumor-like sie, bearing mally
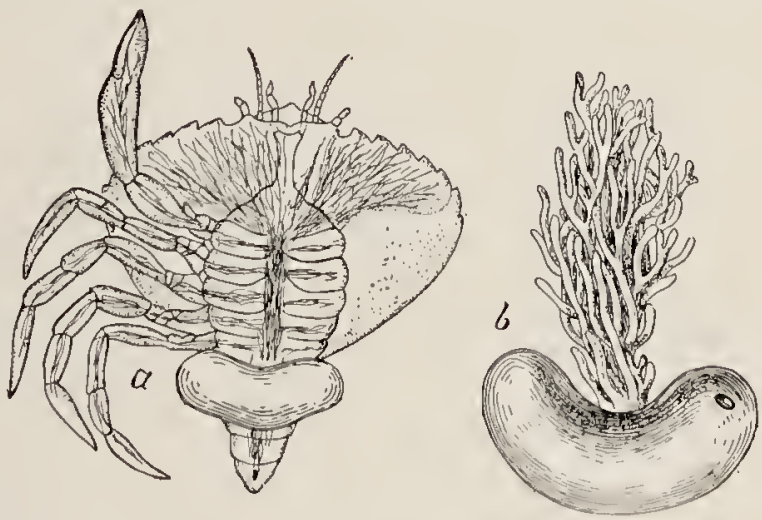

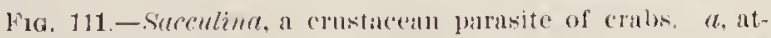
ached to a crab, with root-like proresses penetruting the crabs body; $b$, removed from the crab. delicate root-

like suckers whieh penetratc the body of the erab host and absorb nutriment. The Sarenlina has no eyes, no mouth parts, no legs, or other appendages, and hardly any of the nsual orgaus except reprodnetive organs. Degeneration here is carried very far.

Other parasitie erustacea, as the numerous kinds of fish-liee (Fig. 112) whieh live attaehed to the gills or to 
other parts of fish, and derive all their nutriment from the body of the fish, show various degrees of degeneration. With

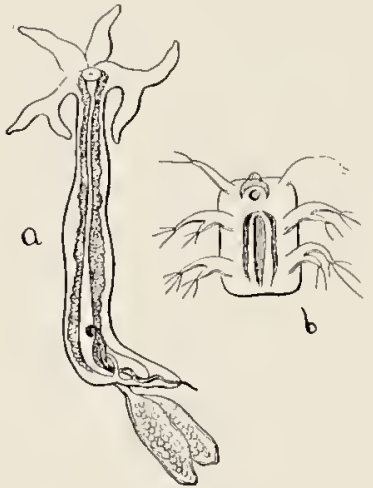

Fif. 112. - Fish-lonke (Lernoocera). $a$, adnlt; $b$, larva.

some of these fish-lice the female, whieh looks like a puffed-out worm, is attaehed to the fish or other aquatie animal, while the male, whieh is perhaps only a tenth of the size of the female, is permanently attaehed to the female, living parasitieally on her.

100. Parasitic insects. - Among the inseets there are many kinds that live parasitieally for part of their life, and not a few that live as parasites for their whole life. The true sueking liee (Fig. 113) and the bird-liee (Fig. 114) live for their whole lives as external parasites on the bodies of their host, but they are not fixed - that is, they retain their legs and power of loeomotion, although they have lost their wings through degeneration. The eggs of the liee are deposited on the hair of the mammal or bird that

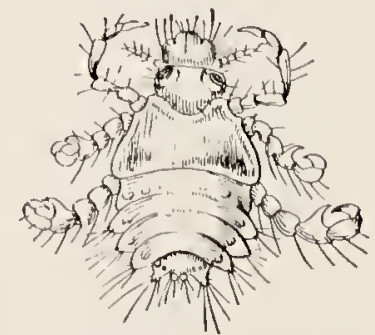

Fre. 113.-Sucking louse (Pediculus) of hummin body.

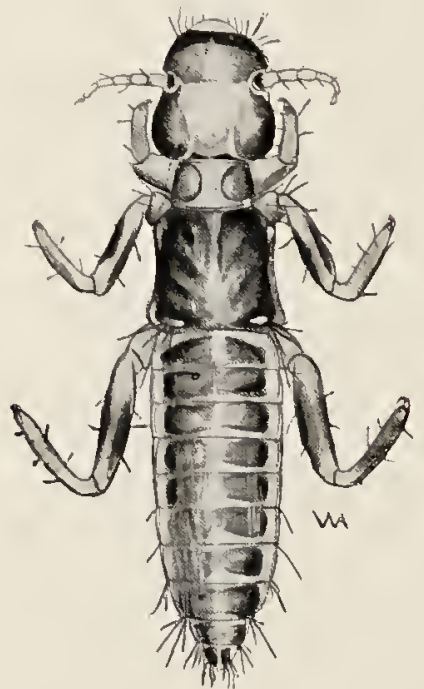

Fiti. 114-1Bird louse (Lipreumes deneus).

serves as host; the young hatch and immediately begin to live as parasites, either sucking the blood or feeding on the 
hair or feathers of the host. In the order Hymenoptera there are several familics, all of whose members live during their larval stage as parasites. We may eall all these lymenopterous parasites iehneumon flies. 'The iehneumon flies are parasites of other insects, especially of the larva of beetles and moths and butterflies. In fact, the iehneumon flies do more to keep in eheek the increase of injurious and destructive eaterpillars than do all our artifieial remedies for these inseet posts. The adult iehneumon fly is fourwinged and lives an active, independent life. It lays its cggs either in or on or near sone eaterpillar or bectle grub, and the young ichneumon, when hatehed, burrows about in the body of its host, feeding on its tissues, but not attaeking sueh organs as the heart or nervous ganglia, whose injury would mean immediate dcath to the host. The eaterpillar lives with the iehnemmon grub within it, usually until nearly

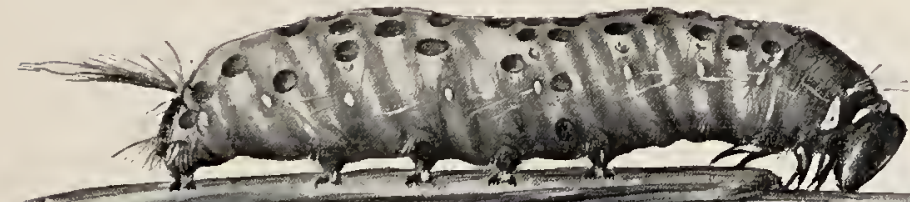

2

FIG. 115.-Parasitized caterpillar from which the ichnenmon lly parasites have issued, showing the circular holes of exit in the skin.

time for its pupation. In many instanees, indeed, it pupates, with the parasite still feeding within its body, but it never comes to maturity. The larval iehnenmon fly pupates eithcr within the body of its host (Fig. 115) or in a tiny silken coeoon outside of its body (Fig. 116). From the encoons the adult winged iehneumon flies cmorge, and after mating find another lost on whose body to lay their eggs.

One of the most interesting iehneumon flies is Thatessa (Fig. 119), whiel has a remarkably long, slender, flexible ovipositor, or egg-laying organ. An insect known as the 
pigeon horn-tail (Tremex columba) (Fig. 11\%) deposits its eggs, by means of a strong, piereing ovipositor, half an ineh deep in the trunk wood of growing trees. The young or
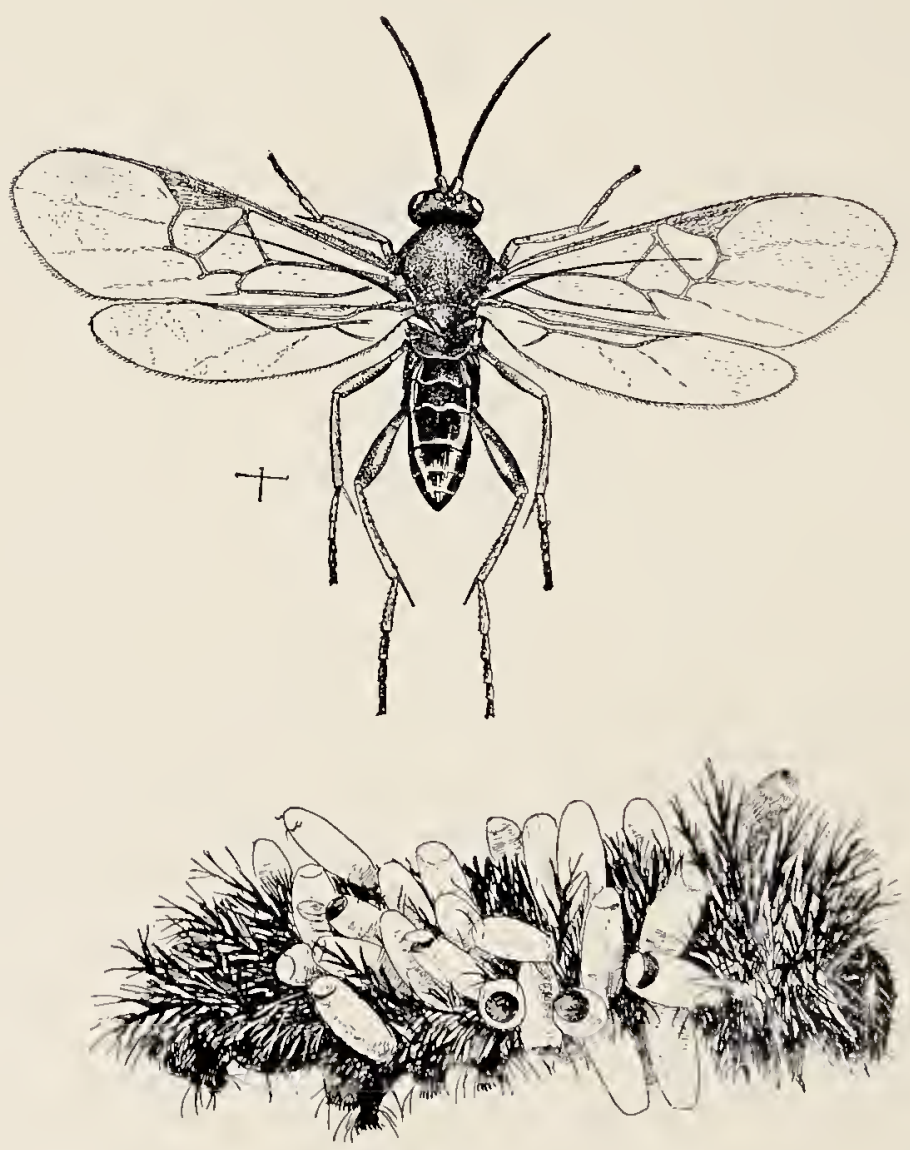

Fia. 116,-Caterpillur with eocoons of the pupe of ichnemmon tly parasites, and (above) one of the adult ichneumon thes. The lines indicate natural dimensions.

larval Tremex is a soft-bodied white grub, which bores deeply into the trunk of the tree, filling up the burlow behind it with small ehips. The Thalesse is a parasite of the Tremex, and "when a female Thulessu finds a tree infested by Tremex, she selects a platee which she judges is opposite 
a Tremex burrow, and, elevating her long ovipositor in a loop over her baek, with its tip on the bark of the tree (Fig.

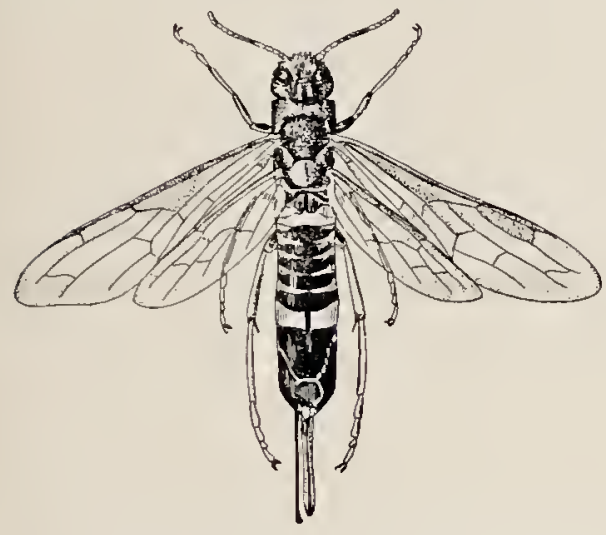

Fir. 11\%.-The pigeon horn-tail (Tremex columba), with strong boring ovipositor.

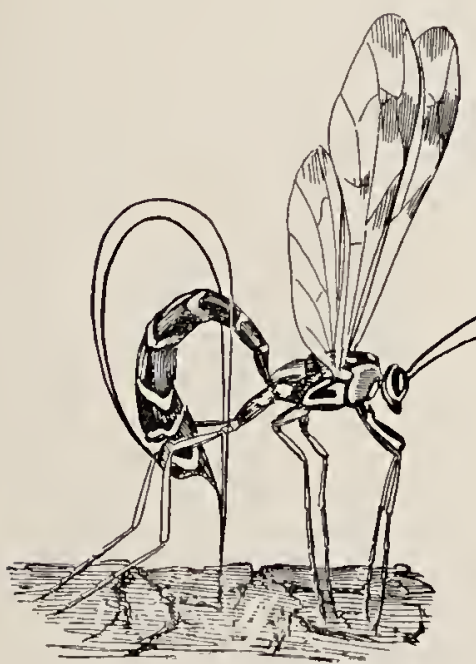

Fig. 118.-Thalessa lunator boring.-After Constuck.

118), she makes a derrick out of her body and proceeds with great skill and precision to drill a hole into the tree. When the Tremex burrow is reaehed she deposits an egg in it. 
The larva that hatehes from this egg ereeps along this burrow until it reaches its vietim, and then fastens itself to the horn-tail larva, which it destroys by sueking its blood.

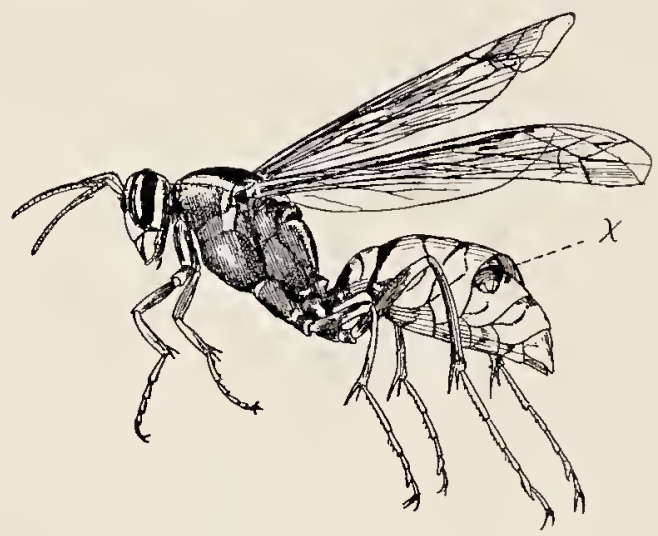

Fig. 120.-Wasp (Polistes), with female Stylops parasite $(x)$ in body.

The larva of Thates$s a$, when full grown, changes to a pupa within the burrow of its host, and the adult gnaws a hole out through the bark if it does not find the hole already made by the Tremex."

The beetles of the family Stylopidx present an interesting ease of parasitism. The adult males are winged, but the adult females are wingless and grub-like. The larval stylopid attaches itself to a wasp or bee, and bores into its abdomen. It pupates within the abdomen of the wasp or bee, and lies there with its head projecting slightly from a suture between two of the body rings of its host (Fig. 120). The adult finally issues and leaves the host's body.

Ahmost all of the mites and tieks, which are more nearly allied to the spiders than to the true insects, live parasitieally. Most of them live as external parasites, sucking the blood of their host, but some live underneath the skin like the iteh-mites

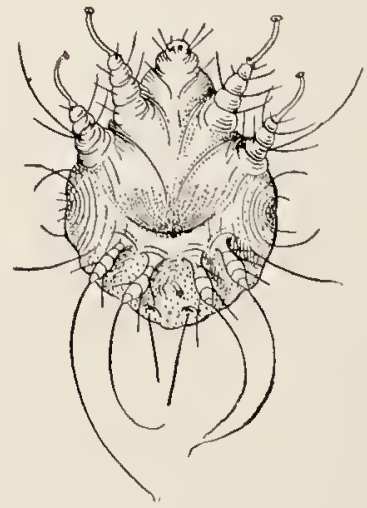

FIG. 121.-The itch-mite (Sarcoptes scabei).

(Fig. 121), which eause, in man, the discase known as the iteh. 
101. Parasitic vertebrates. - Among the vertebrate animals there are not many examples of true parasitism. The hag-fishes or borers (Myxine, Heptatrenia, Polistotrema) are long and cylindrical, eel-like creatures, very slimy and very low in structure. The mouth is without jaws, but forms a sucking disk, by which the hag-fish attaches itself to the body of some other fish. By means of the rasping teeth on its tongue, it makes a round hole through the skin, usually at the throat. It then devours all the muscular substance of the fish, leaving the viscera untouched. When the fish finally dies it is a mere hulk of skin, sealcs, bones, and viscera, nearly all the musele being gone. Then the hagfish slips out and attacks another individual.

The lamprey, another low fish, in similar fashion feeds leech-like on the flesh of other fishes, which it scrapes out with its rasp-like tceth, remaining attached by the round sucking disk of its mouth.

Certain birds, as the cow-bird and the European cuekoo, have a parasitic habit, laying their eggs in the nests of other birds, leaving their young to be hatehed and reared by their unwilling hosts. This is, however, not bodily parasitism, such as is seen among lower forms.

102. Degeneration through quiescence. - While parasitism is the principal cause of degeneration among animals, yet it is not the sole cause. It is evident that it for any other reason animals should become fixed, and live inactive or sedentary lives, they would degenerate. And there are not a few instances of degencration due simply to a quiescent life, unaccompanied by parasitism. The 'Iunicata, or seasquirts (Fig. 122), are animals which have become simple through degeneration, due to the adoption of a scdentary life, the withdrawal from the crowd of animals and from the struggle which it necessitates. The young tunicate is a free-swimming, active, tadpole-like or fish-like creature, which possesses organs very like those of the adult of the simplest fishes or fish-like forms. That is, the sea-squirt 
begins life as a primitively simple vertebrate. It possesses in its larval stage a notoehord, the delicate strueture which preeedes the formation of a baekbone, extending along the

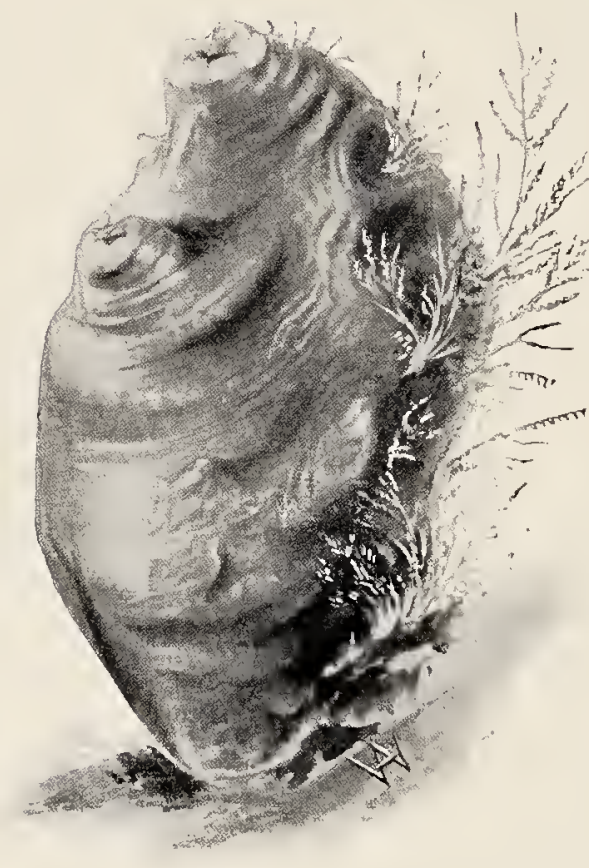

Fta. 122. - A sea-squirt, or tunicate.

upper part of the body, below the spinal eord. It is found in all young vertebrates, and is eharaeteristie of the class. The other organs of the young tunieate are all of vertebral type. But the young sea-squirt passes a period of aetive and free life as a little fish, after whieh it settles down and attaehes itself to a stone or shell or wooden pier by means of suekers, and remains for the rest of its life fixed. Instead of going on and developing into a fish-like creature, it loses its notoehord, its speeial sense organs, and other organs; it loses its eomplexity and high organization, and beeomes a "mere rooted bag with a double neck," a thoroughly degenerate animal.

A barnacle is another example of degeneration through quieseence. 'The barnaeles are crustaceans related most nearly to the crabs and shrimps. The young barnaele just from the egg (Fig. 123, $f$ ) is a six-legged, free-swimming nauplins, very like a young prawn or crab, with single eye. In its next larval stage it has six pairs of swimming feet, two compound eyes, and two large antennæ or feelers, and still lives an independent, free-swimming life. When it makes its final ehange to the adult condition, it attaches 
itself to some stone or shcll, or pile or ship's bottom, loses its compound cyes and feelers, develops a protecting shell, and gives up all power of loeomotion. Its swimming feet beeome ehanged into grasping organs, and it loses most of its outward resemblanees to the other members of its class (Fig. 123,e).

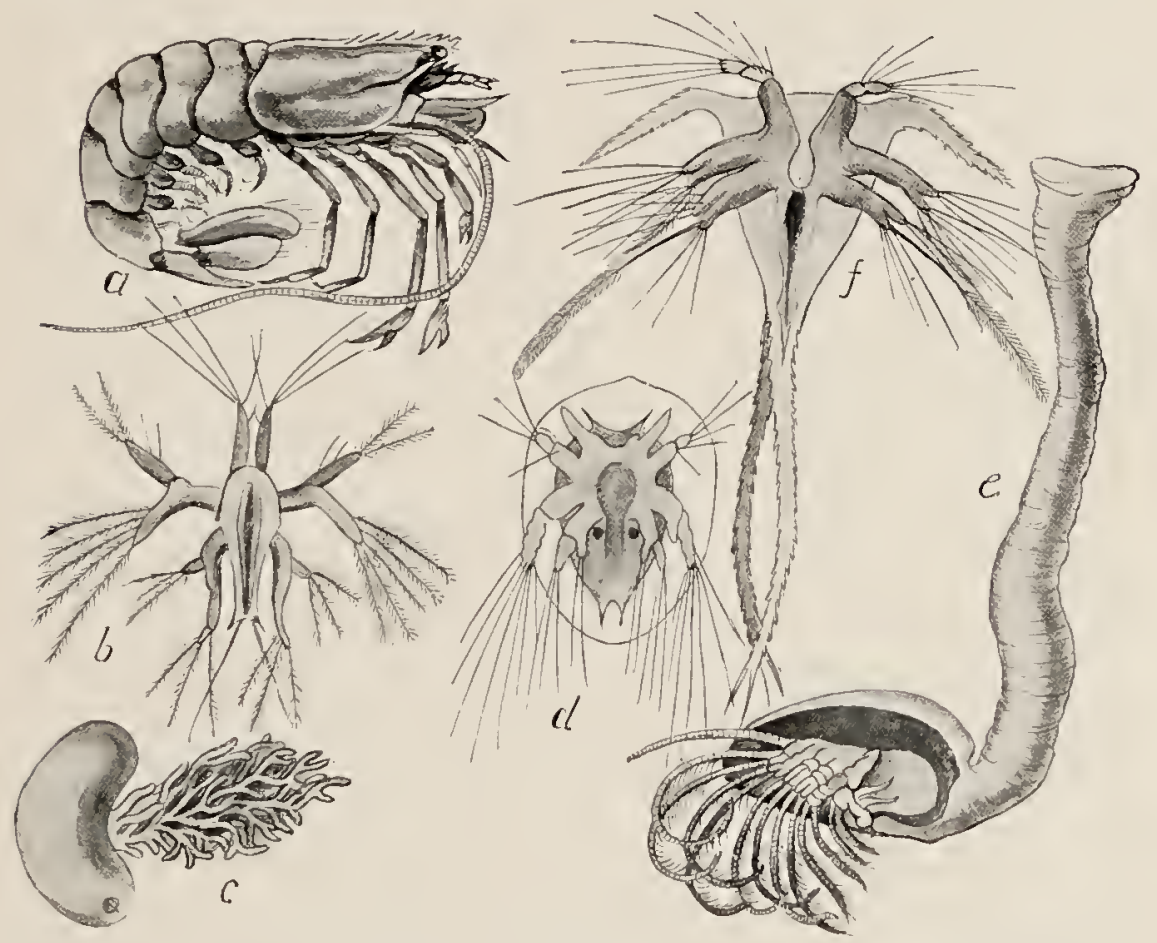

Fig. 123. - Three adult crustacenns and their larve. a, prawn (Peneus), active aud free-living: b. larva of prawn; $c$, Sacmlina, parasite ; $\hat{d}$, larva of sacmlina: $e$, barnacle (Lepas), with fixed quiescent life; $f$, larva of barnacle.-After HAECKEL.

Certain inseets live sedentary or fixed lives. All the members of the family of seale inscets (Coecida), in one sex at least, show degeneration, that has becn eaused by quieseence. Onc of these coeeids, called the red orange seale (Fig. 124), is very abundant in Florida and California and in other orange-growing regions. The male is a beantiful, tiny, two-winged midge, but the female is a wingless, 
footless little sae without eyes or other organs of special sense, whieh lies motionless under a flat, thin, eireular, reddish seale eomposed of wax and two or three cast skins of the inseet itself. The inseet has a long, slender, flexible, sueking beak, whieh is thrust into the leaf or stem or fruit of the orange on which the "seale bug" lives and through whieh the inseet sueks the orange sap, which is its only

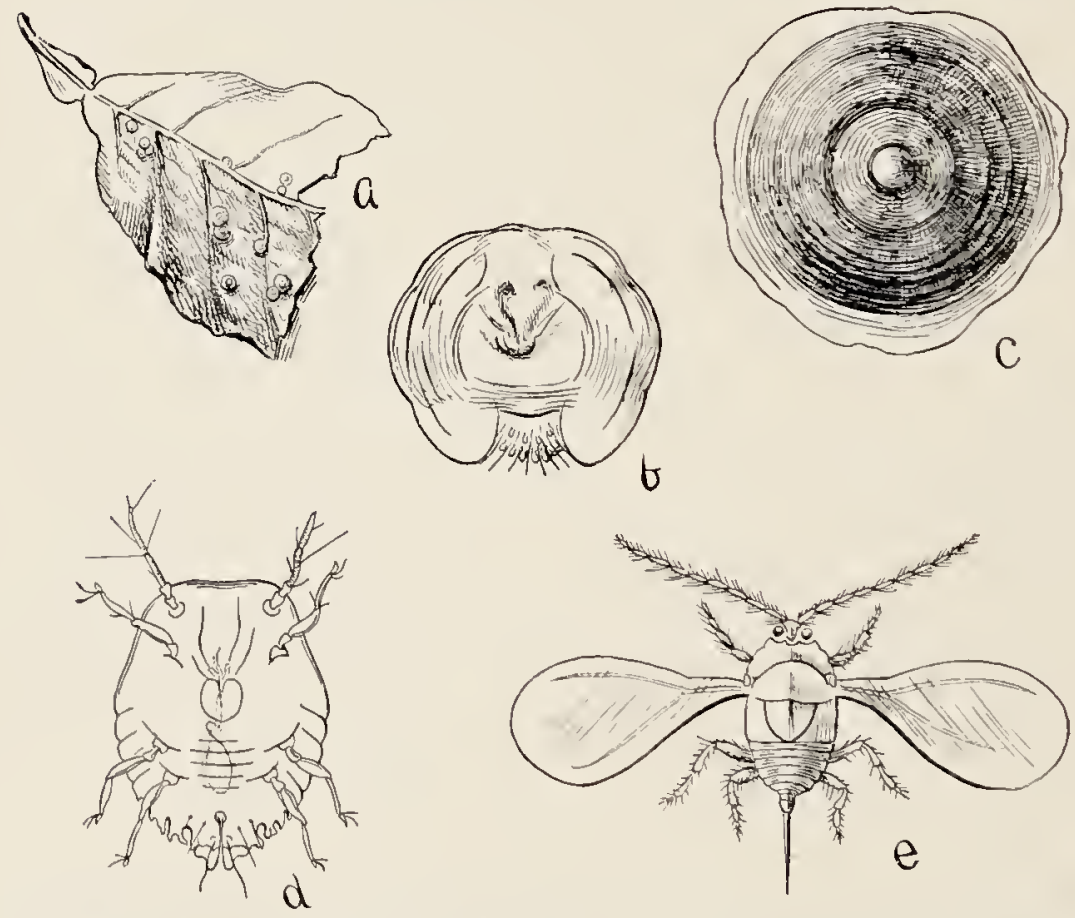

Fra. 12t.- l'he red orange scale of Califormiu. $a$, bit of leaf with seales; $b$, adult female; c, wax scale muder which adult fomale lives; d, larva; $e$, adult male.

food. It lays eggs moler its body, and thus also moler the proteeting wax seale, and dies. From the eggs hateh aletive little larral seale-bugs with eyes and feelers and six legs. 'They crawl from under the wax scale and roam about over the orange tree. Finally, they settle down, thrusting their sucking beak into the plant tissues, and east their skin. The females lose at this molt their legs and eyes and 
feelers. Each beeomes a mere motionless sae eapable only of sueking up sap and of laying eggs. The young males, however, lose their sueking beak and ean no longer take food, but they gain a pair of wings and an additional pair of eyes. They fly about and fertilize the sae-like females, whieh then molt again and seerete the thin wax seale over them.

Throughout the animal kingdom loss of the need of movement is followed by the loss of the power to move, and of all struetures related to it.

103. Degeneration through other causes.-Loss of eertain organs may oeeur through other eauses than parasitism and a fixed life. Many inseets live but a short time in their adult stage. May-flies live for but a few hours or, at most, a few days. They do not need to take food to snstain life for so short a time, and so their mouth parts have beeome rudimentary and funetionless or are entirely lost. This is true of some moths and numerous other speeially shortlived inseets. Among the soeial inseets the workers of the termites and of the true ants are wingless, although they are born of winged parents, and are deseendants of winged aneestors. The modifieation of strueture dependent upon the division of labor among the individuals of the eommunity has taken the form, in the ease of the workers, of a degeneration in the loss of the wings. Inseets that live in eaves are mostly blind; they have lost the eyes, whose funetion eould not be exereised in the darkness of the cave. Certain island-inhabiting inseets have lost their wings, flight being attended with too nueh danger. The strong sea-breezes may at any time earry a flying inseet off the small island to sea. Only those which do not fly mueh survive, and by natural seleetion wingless breeds or speeies are produeed. Finally, we may mention the great modifieations of strueture, often resulting in the loss of eertain organs, which take plaee to produee proteetive resemblanees (see Chapter XII). In sueh eases the body may be modified in 
color and shape so as to rescmble some part of the environment, and thus the animal may be unperceived by its enemies. Many inseets have lost their wings through this cause.

104. Immediate causes of degeneration.- Trhen we say that a parasitic or quiescent modc of life leads to or causes degeneration, we have explained the stimulus or the ultimate cause of degenerative changes, but we have not shown just how parasitism or quiescence actually produces these changes. Degeneration or the atrophy and disappearance of organs or parts of a body is often said to be due to disuse. That is, the disuse of a part is believed by many naturalists to be the sufficient cause for its gradual dwindling and final loss. That disuse can so affect parts of a body during the lifetime of an individual is true. A muscle unused becomes soft and flabby and small. Thether the effects of such disuse can be inhcrited, howerer, is open to serious doubt. Such inhcritanee must be assumed if disuse is to account for the gradnal growing less and final disappearance of an organ in thc conrse of many generations. Some naturalists bclievc that the results of such disuse can be inherited, but as yct such belief rests on no cortain knowledge. If claracters assmmed during the lifetime of the individual are subject to inheritance, disuse alone may explain degcneration. If not, some other immcdiate cause, ol some other cause aloug with disuse, must be found. Such a causc unust be sought for in the aetion of natural sclection, pleserving the advantages of simplieity of structurc wherc action is not required.

105. Advantages and disadvantages of parasitism and degeneration. - Wc are accustomed, perhaps, to think of degencration as necessarily implying a disadvantage in lifc. A degencratc animal is cousidered to be not the equal of a nondegencrate animal, and this would be truc if both kinds of animals had to face the same eonditions of life. The blind, footless, simple, degencrate animal could not cope with the 
active, keen-sighted, highly organized non-degenerate in free eompetition. But free competition is exaetly what the degenerate animal has nothing to do with. Certainly the Saccutina lives suecessfully; it is well adapted for its own peeuliar kind of life. For the life of a scale inseet, no better type of strueture could be derised. A parasitc enjoys certain obvious advantages in life, and even cxtreme degeneration is no drawback, but rather favors it in the advantageousness of its sheltcred and easy life. As long as the host is successful in eluding its enemies and avoiding aceident and injury, the parasite is safe. It needs to exereise no activity or vigilanee of its own; its life is casy as long as its host lives. But the disadvantages of parasitism and degeneration are apparent also. 'The fatc of the parasite is usually bound up with the fate of the host. When the enemy of the host erab prevails, the Sacculina goes down without a ehance to struggle in its own defense. But far more important than the disadvantage in such partieular or individual cases is the disadvantage of the fact that the parasite ean not adapt itsclf in any eonsiderable degree to new conditions. It has become so speeialized, so greatly modified and ehanged to adapt itsclf to the one set of conditions under which it now lives; it has gone so far in its giving up of organs and body parts, that if present conditions should change and new ones come to exist, the parasite eould not adapt itself to them. The independent, aetive animal with all its organs and all its funetions intact, holds itself, one may say, ready and able to adapt itself to any new eonditions of life which may gradually come into existence. The parasitc has risked everything for the sake of a sure and easy life under the prescntly existing conditions. Change of conditions means its extinction.

106. Human degeneration.-It is not proposed in these pages to discuss the application of the laws of animal life to man. But each and every onc extends upward, and ean 
be traced in the relation of men and society. Thus, among men as among animals, self-dependence favors complexity of power. Dependence, parasitism, quiescence faror degeneration. Degeneration means loss of complexity, the narrowing of the range of powers and capabilities. It is not necessarily a phase of disease or the precursor of death. But as intellectual and moral excellence are matters associated with high development in man, dependence is unfavorable to them.

Degeneration has been called animal pauperism. Pauperism in all its forms, whether due to idleness, pampering, or misery, is human degeneration. It has been shown that a large part of the criminality and pauperism among men is hereditary, due to the survival of the tendency toward living at the expense of others. The tendency to live without self-activity passes from generation to generation. Beggary is more profitable than unskilled and inefficient labor, and onr ways of careless charity tend to propagate the beggar. That form of charity which does not render its recipient self-hclpful is an incentive toward degcneration. Withdrawal from the competition of life, withdrawal from self-helpful activity, aided by the voluntary or involuntary assistance of others-these factors bring abont degeneration. The same results follow in all ages and with all races, with the lower animals as with men. 


\section{CHAPTER XII}

\section{PROTECTIVE RESEMBLANCES, AND MIMICRY}

10\%. Protective resemblance defined.-If a grasshopper be startled from the ground, you may watel it and determine exaetly where it alights after its leap or flight, and yet, on going to the spot, be wholly mable to find it. The eolors and marking of the inseet so harmonize with its surroundings of soil and vegetation that it is nearly indistinguishable as long as it remains at rest. And if you were intent on eapturing grasshoppers for fish-bait, this resemblanee in appearanee to their surroundings would be very annoying to you, while it would be a great advantage to the grasshoppers, proteeting some of them from eapture and death. This is protective resemblance. Mere easual observation reveals to us that such instanees of proteetive resemblanee are very eommon among animals. A rabbit or grouse eroulhing close to the ground and remaining motionless is almost indistinguishable. Green eaterpillars lying outstretehed along green grass-blades or on green leaves may be touched before being reeognized by sight. In aretie regions of perpetual snow the polar bears, the snowy aretie foxes, and the hares are all pure white instead of brown and red and gray like their eousins of temperate and warm regions. Animals of the desert are almost without exception obseurely mottled with gray and sand eolor, so as to harmonize with their smrromdings.

In the struggle for existence anything that may give an animal an advantage, however slight, may be sufficient to turn the seale in favor of the organism possessing the 
advantage. Such an advantagc may be swiftness of movement, or unusual streugth or capacity to withstand unfavorable meteorological conditions, or the possession of such color and markings or peculiar shape as tend to conceal the animal from its cncmies or from its prey. Resemblances may scrve the purpose of aggression as well as protection. In the case of the polar bears and other predaceous animals that show color likenesses to their surroundings, the resemblance can better be called aggressive than protective. The concealment afforded by the resemblance allows them to steal unpcrceived on their prey. This, of course, is an advantage to them as truly as escape from enemies would be.

We have already seen that by the action of natural selection and heredity those variations or conditions that give animals advantages in the struggle for life are preserved and emphasized. And so it has come about that advantageous protective resemblances are very widespread among animals, and assume in many cases extraordinarily striking and interesting forms. In fact, the explanation of much of the coloring and patterning of animals depends on this principle of protective resemblance.

Beforc considering further the gencral conditions of protective resemblances, it will be advisable to refer to specific cximples classificl roughly into gronps or special kinds of adrantageous colorings and markings.

108. General protective or aggressive resemblance.-As examples of general protectire resemblance-that is, a general color cflect harmonizing with the usual surroundings and tending to hide or render indistinguishable the animal - may be mentioned the hue of the green parrots of the evergreen tropical forests; of the green tree-frogs and treesnakes which live habitually in the grcen foliage; of the mottled gray and tawny lizards, birds, and small mammals of the deserts; and of the white hares and foxes and snowy owls and ptarmigans of the snow-covered arctic regions. Of the same nature is the slaty blue of the 


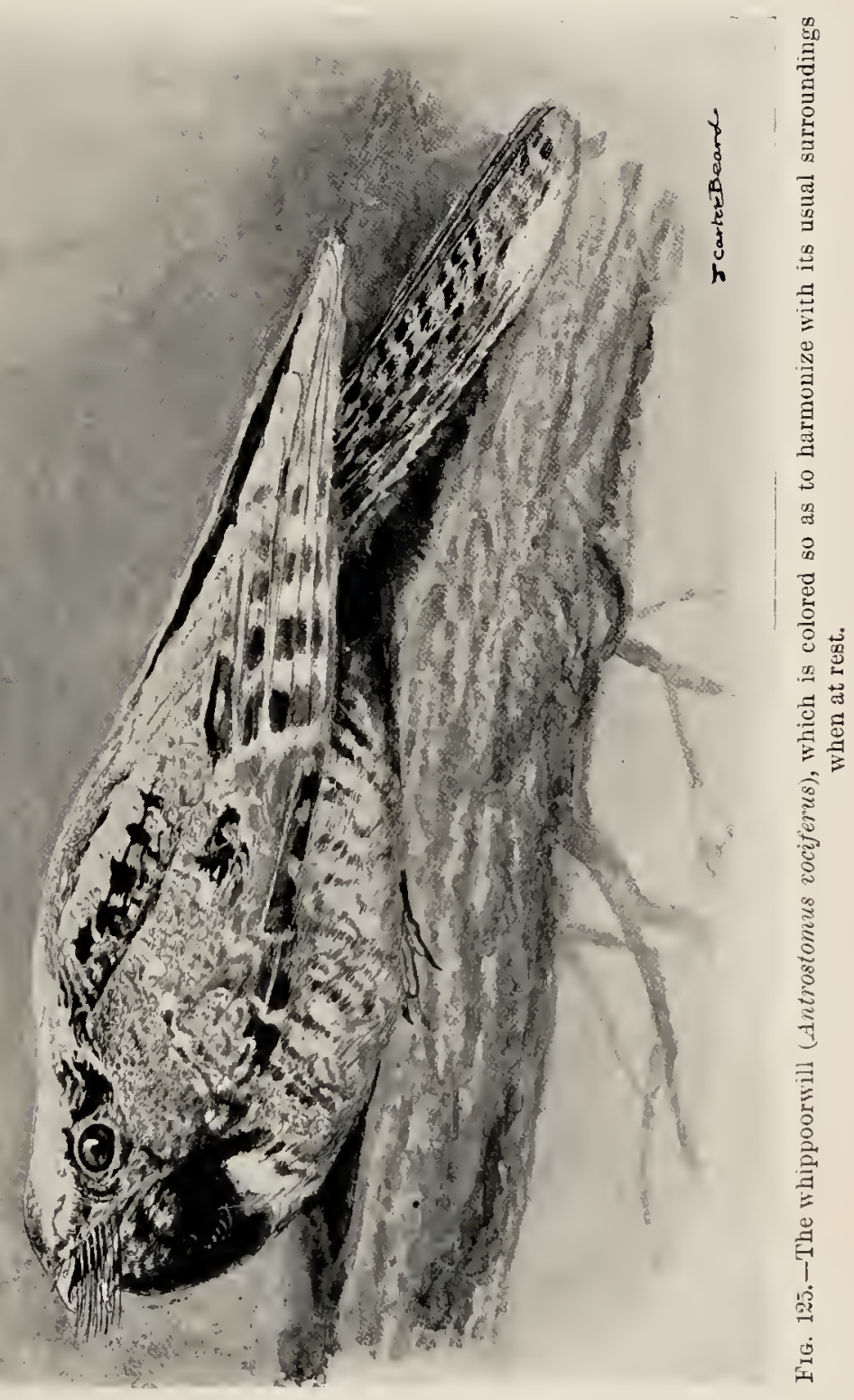


gulls and terns, eolored like the sea. In the brooks most fishes are dark olive or greenish above and white below. To the birds and other enemies whieh look down on them from above they are eolored like the bottom. To their fish enemies which look up from below, their eolor is like the white light above them, and their forms are not elearly seen. The fishes of the deep sea in perpetual darkness are *

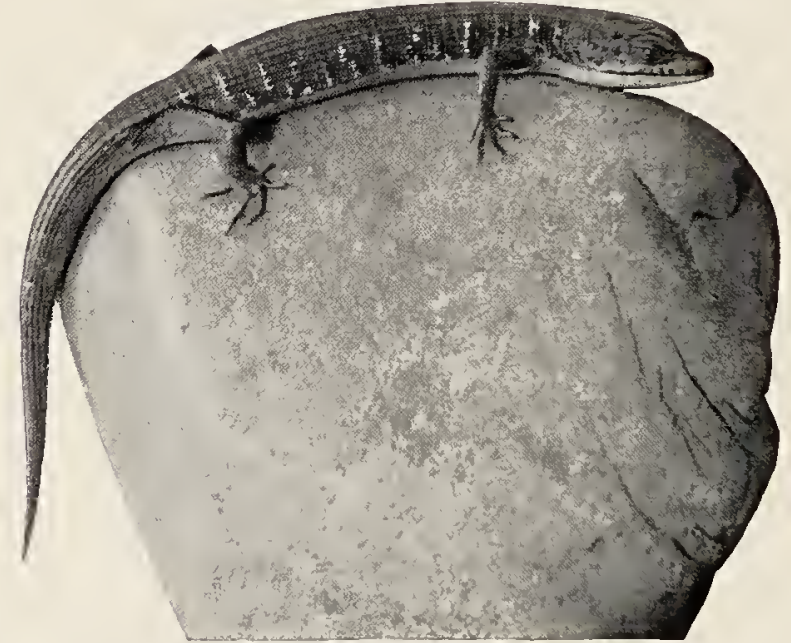

Fia. 126.-Alligator lizand (frerhonotus scincicaula) on granite rock. Plotograph by J. O. Snyder, Stanford University, California.

inky violet in eolor below as well as above. Those that live among sea-weeds are red, grass-green, or olive, like the plants they frequent. General proteetive resemblanee is very widespread among animals, and is not easily appreeiated when the animal is seen in museums or zoülogieal gardens-that is, away from its natural or normal environment. $\Lambda$ modification of general eolor resemblanee found in many animals may be ealled variable proteetive resemblanee. Certain hares and other animals that live in northerm batitudes are wholly white during the winter when the snow covers everything, but in summer, when mueh of the snow melts, revealing the brown and gray roeks and 
withered leares, these creatures change color, putting on a grayish and brownish coat of hair. The ptarmigan of the Rocky Mountains (one of the grouse), which lives on the snow and rocks of the high peaks, is almost wholly white in winter, but in summer when most of the snow is melted its plumage is chiefly brown. On the campus at Stanford University there is a little pond whose shores are corered in some places with bits of bluish rock, in other places with bits of reddish rock, and in still other places with sand. A small inscet called the toad-bug (Galgulus oculatus) lives abundantly on the banks of this pond. Specimens collected from the blue rocks are bluish in color, those from the red rocks are reddish, and those from the sand are sand-colored. Such changes of color to suit the changing surroundings can be quickly made in the case of some animals. The chameleons of the tropics, whose skin changes color momentarily from green to brown, blackish or golden, is an excellent example of this highly specialized condition. The same change is shown by a small lizard of our Southern States (Anolius), which from its habit is called the Florida chameleon. 'There is a little fish (Oligocollus snyderi) which is common in the tide pools of the bay of Monterey, in California, whose color changes quickly to harmonize with the different colors of the rocks it happens to rest above. Some of the treefrogs show this variable coloring. A very striking instance of variable protective

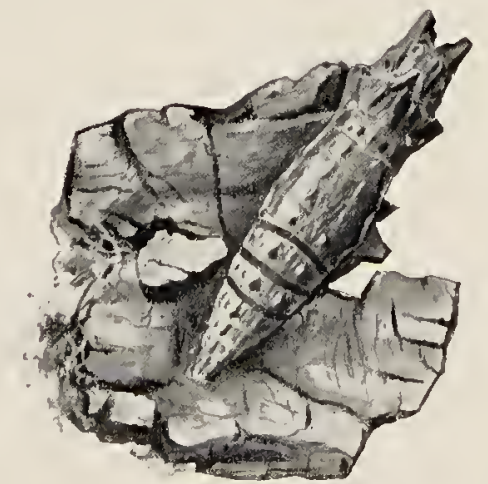

Fig. 127.-Chrysalid of swallow-tail butterfly (Papilio), harmonizing with the bark on which it rests. resemblance is shown by the chrysalids of certain butterflies. An eminent English natmalist collected many caterpillars of a certain spccies of 
butterfly, and put them, just as they were about to change into pupæ or chrysalids, into various boxes, lined with paper of different colors. The color of the chrysalid was found

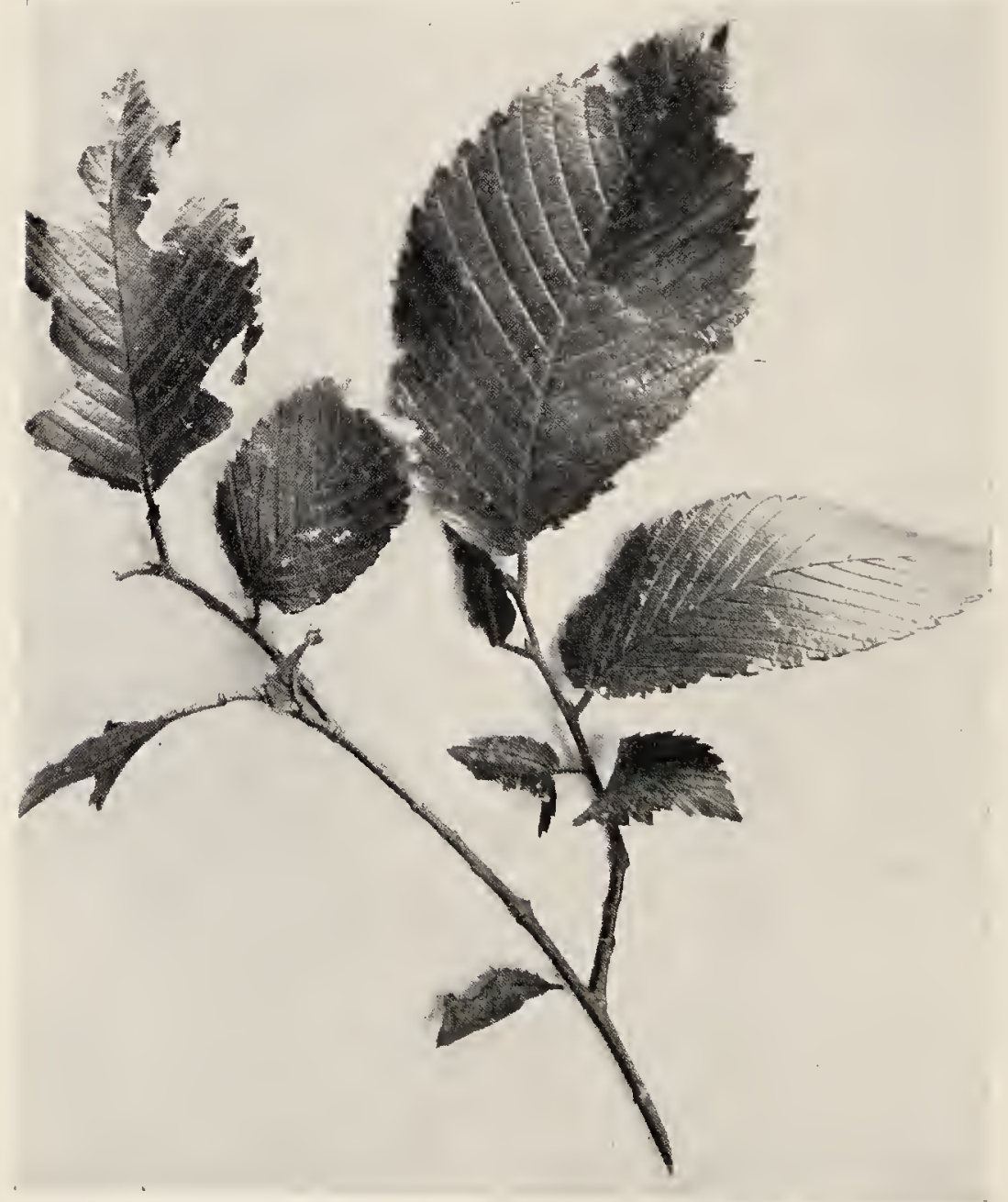

Fuc. 128.-Chrysalid of butterfly (lower left-hand projection from stem), showing protective resemblance. Photograph from Nature.

to harmonize very plainly with the color of the lining of the box in which the chrysalid hung. It is a familiar fact to entomologists that most butterfly chrysalids resemble in 
color and general external appearance the surface of the object on which they rest (Figs. 127 and 128).

109. Special protective resemblance.-Far more striking are those cases of protective resemblance in which the animal resembles in color and shapc, sometimes in extraordinary detail, some particular object or part of its usual environment. Certain parts of the Atlantic Ocean are covered with great patches of sca-weed called the gulf-weed (Sargassum), and many kinds of animals-fishes and other creatures-live upon and among the algæ. No one can fail to note the extraordinary color resemblances which cxist between those animals and the weed itself. The gulf-weed is of an olive-yellow color, and the crabs and shrimps, a certain flat-worm, a certam mollusk, and a little fish, all of which live among the Sargassum, are exactly of the same shade of yellow as the wced, and have small white markings on their bodies which are characteristic also of the surgassum. The mouse-fish or Surgassum fish and the little seahorses, often attached to the gulf-weed, show the samc traits of coloration (Fig. 129). In the black rocks about Tahifi is found the black nokce or lava-fish (Emmydrichlhys vulcenus) (Fig. 66), which corresponds perfectly in color and form to a piece of lava. This fish is also noteworthy for having envenomed spines in the fin on its back. The slender grass-grecn catcrpillars of many moths and buttcrflics resemble very closely the thin grass-blades among which they live. 'The larre of the geometrid moths, called inch-worms or span-worms, are twig-like in appearance, and have the habit, when disturbed, of standing out stiffly from the twig or branch upon which they rest, so as to resemble in position as well as in color and markings a short or a broken twig. One of the most striking resemblances of this sort is shown by the large geometrid larva illustrated in Fig. 130, which was found near Ithaca, New York. The body of this caterpillar has a few small, irregular spots or humps, rescmbling very exactly the scars left by fallen 


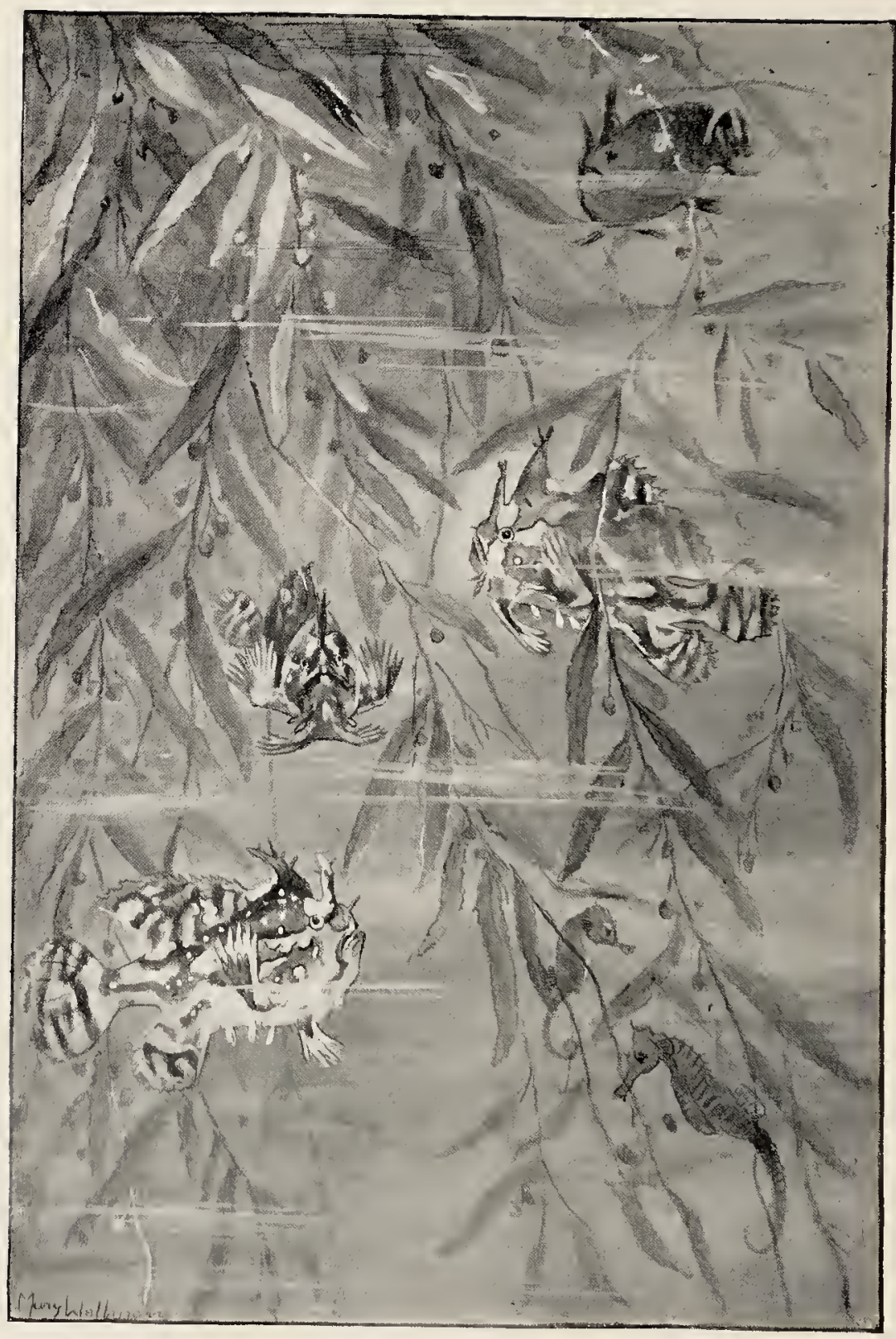

Fis. $1: 9$. The mouse-fish (Pterophryne histrio) in the Surgussum or gnlf-weed. The fishes are marked and eolored so as to be nearly indistinguishable from the masses of the gulf-weed. In the lower right-hand corner of figure are two sea-horses, also shaped and marked so as to be concealed. 
buds or twigs. These caterpillars have a special museular development to enable them to hold themselves rigidly for

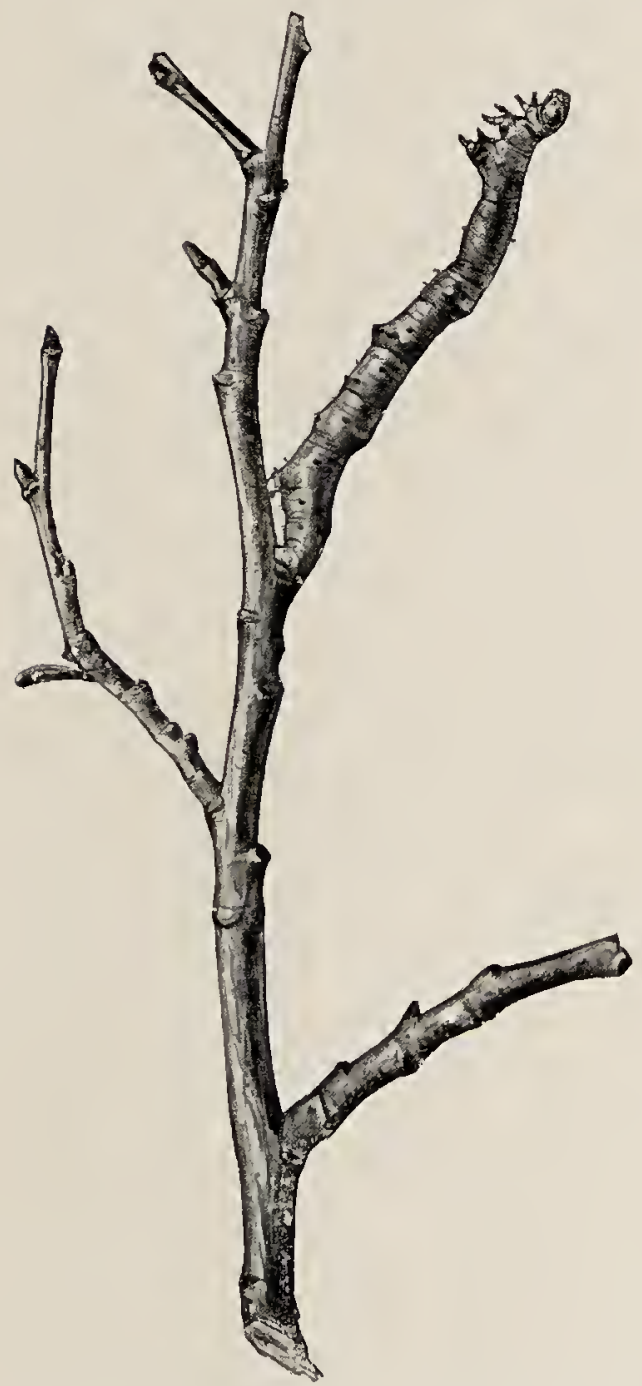

Fig. 130.-A geometrid larva on a braneh. (The larva is the upper right-haud projection from the stem.)

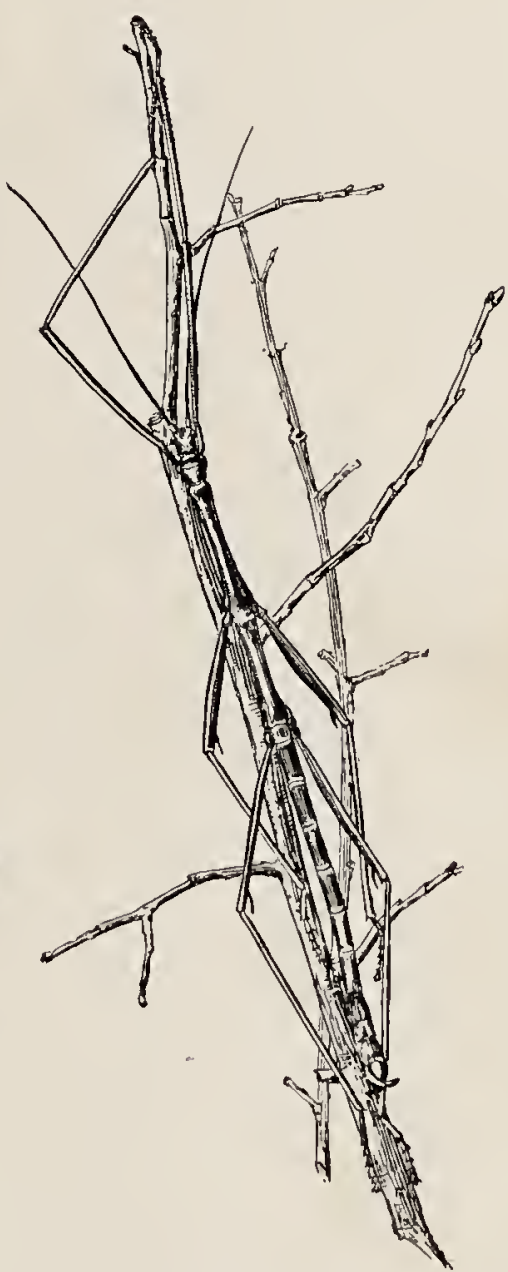

Fig. 131.-A walking-stick insect (Inapheromera femorata) on twig.

long times in this trying attitude. They also lack the middle prop-legs of the body, eommon to other lepidopter- 
ous larve, which would tend to destroy the illusion so successfully carried out by them. The common walkingstick (Diaphoromera) (Fig. 131), with its wingless, greatly elongate, dull-colored body, is an excellent example of special protective resemblance. It is quite indistinguishable, when at rest, from the twigs to which it is clinging. Another member of the family of insects to which the walking-stick belongs is the famous green-leaf insect (Ployllium)

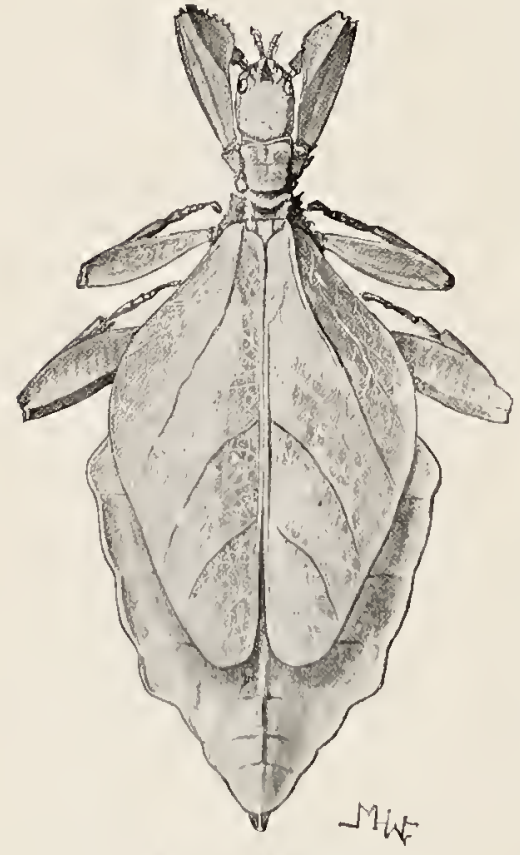

FH. 13:. The erren-leaf insect (IMylliuln.).

(Fig. 132). It is found in South America and is of a bright green color, with broad leaf-like wings and body, with markings which imitate the leaf veins, and small irregular yellowish spots which mimic decaying or stained or fungus-covered spots in the leaf.

There are many butterflies that rescmble dead leaves. All our common meadow browns (Grapta), brown and redish butterflies with ragged-edged wings, that appear in the autumn and flutter aimlessly about $\mathrm{cx}-$ actly like the falling leares, show this resemblanee. But most remarkable of all is a large butterfly (Katlima) (Fig. 133) of the East Indian region. The nlper sides of the wings are dark, with purplish and orange markings, not at all resembling a dead leaf. But the butterflies when at rest hold their wings together over the back, so that only the under sides of the wings are exposed. 'The under sides of fiallima's wings are exactly the color of a dead and dried leaf, and 
the wings are so held that all combine to mimic with extraordinary fidelity a dead leaf still attached to the twig by a short pedicle or leaf-stalk imitated by a short tail on the

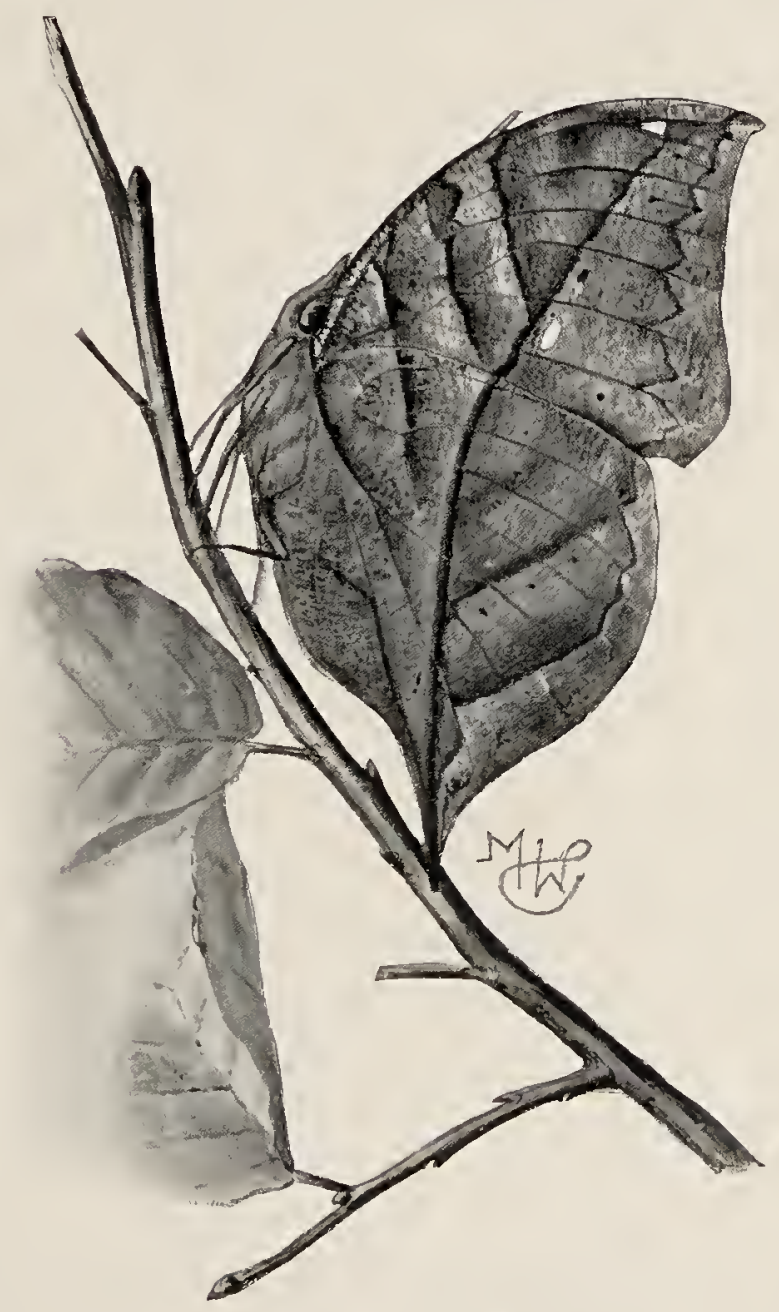

Fig. 133.-Kallima, the "dead-leaf butterfly."

hind wings, and showing midrib, oblique veins, and, most remarkable of all, two apparent holes, like those made in leaves by insects, but in the butterfly imitated by two small circular spots free from scales and hence clear and trans- 
parent. With the head and feelers concealed beneath the wings, it makes the resemblance wonderfully exact.

There are numerous instances of special protective rcscmblance among spiders. Many spiders (Fig. 134) that
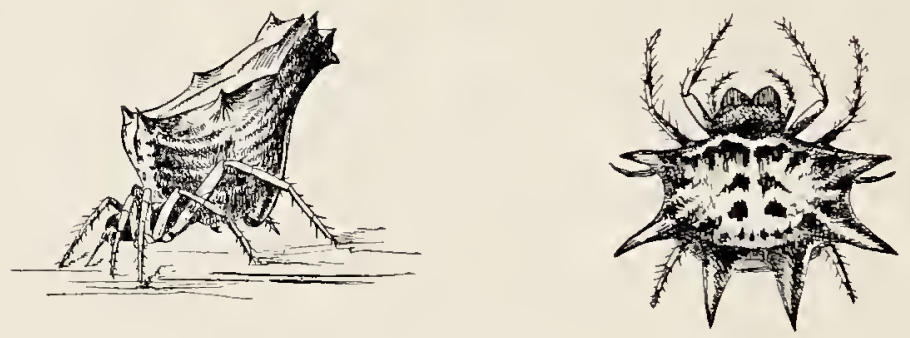

FIG. 134.-Spiders showing unusual shapes and patterns, for purposes of aggressive resemblance.

live habitually on tree trunks resemble bits of bark or small, irregular masses of lichen. A whole family of spiders, which live in flower-cups lying in wait for insccts, are white and pink and party-colored, rcsembling the markings of the special flowers frequented by them. This is, of course, a

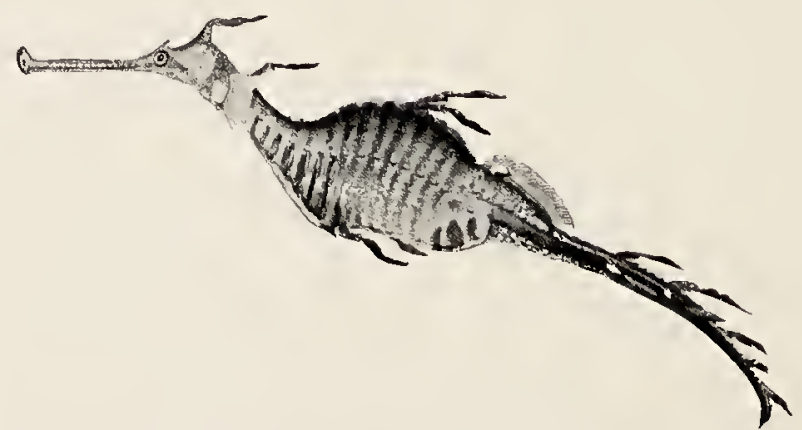

If16. 135. $-\Lambda$ pipe-fish (Ihyllopteryx) resenbling sea-wecd, in which it lives.

special resemblance not so much for protection as for aggression; the insects coming to visit the flowcrs are unable to distinguish the spiders and fall an easy prey to them.

110. Warning colors and terrifying appearances.-In the cases of advantageous coloring and patterning so far dis- 
cussed the advantage to the animal lies in the rescmblance between the animals and their surroundings, in the inconspicuousness and concealment afforded by the coloration. But there is another interesting phase of advantageous coloration in which the advantage derived is in rendering the animals as conspicuous and as rcadily recognizable as possible. While many animals are very inconspicuously colored, or are manifestly colored so as to resemble their surroundings, generally or spccifically, many other animals are very brightly and conspicuously colored and patterned. If we are struck by the numcrous cascs of imitative coloring among insccts, we must be no less impressed by the many cases of bizarre and conspicuous coloration among them.

Many animals, as we wcll know, possess special and cffective weapons of defcnse, as the poison-fangs of the venomous snakes and the stings of bees and wasps. Other animals, and with these cases most of us are not so well acquainted, possess a means of defcnse, or rather safety, in being inedible-that is, in possessing somc acrid or illtasting substance in the body which renders them umpalatable to predaccous animals. Many caterpillars have been found, by observation in Nature and by experiment, to be distasteful to insectivorous birds. Now, it is obvious that it would be a great advantage to these catcrpillars if they could be readily recognized by birds, for a severe stroke by a bird's bill is about as fatal to a catcrpillar as being wholly eaten. Its soft, distended body suffers mortal hurt if cut or bitten by the bird's beak. 'This advantagc of being rcadily rccognizable is possessed by many if not all illtasting catcrpillars by being brilliantly and conspicuously colored and marked. Such colors and markings are called. warning colors. They are intended to inform birds of the fact that the caterpillar displaying them is an ill-tasting insect, a caterpillar to be let alonc. The conspicuously black-and-yellow banded larva (Fig. $43, b$ ) of the common 
Monarch butterfly is a good example of the possession of warning eolors by distasteful eaterpillars.

These warning eolors are possessed not only by the illtasting eaterpillars, but by many animals which have special means of defense. The wasps and bees, provided with stings-dangerous animals to tronble-are almost all conspienously marked with yellow and black. The lady-bird beetles (Fig. 136), composing a whole family of small beetles
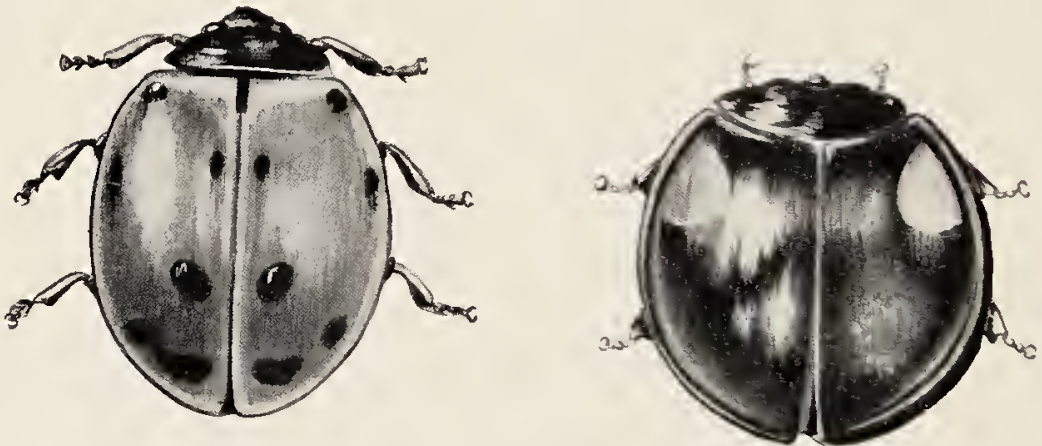

Fig. 136.-Two lady-bird beetles, conspicuously colored and marked.

which are all ill-tasting, are brightly and conspienonsly eolored and spotted. The Gila monster (Iteloderma), the only poisonous lizard, differs from most other lizards in being strikingly patterned with blaek and brown. Some of the venomous snakes are eonspicuously colored, as the eoral snakes (Elaps) or coralillos of the tropies. 'The raturalist Belt, whose observations in Nicaragua have adrled mueh to our knowledge of tropieal animals, descrilses as follows an interesting example of warning colors in a speeies of frog: "In the woods around Santo Domingo (Niearagua) there are many frogs. Some are green or brown and imitate green or dead leaves, and live among foliage. Others are dull earth-eolored, and hide in holes or imder logs. All these come out only at night to feed, and they are all preyed npon by snakes and birds. In contrast with these obseurcly colored species, another little frog hops abont in 
the daytime, dressed in a bright livery of red and blue. He ean not be mistaken for any other, and his flaming breast and blue stoekings show that he does not court concealment. He is very abundant in the damp woods, and I was convineed he was uneatable so soon as I made his aequaintance and saw the happy sense of security with which he hopped about. I took a few specimens home with me, and tried my fowls and dueks with them, but none would touch them. At last, by throwing down piees of meat, for which there was a great eompetition among them, I managed to entiee a young duek into snatching up one of the little frogs. Instead of swallowing it, however, it instantly threw it ont of its month, and went about jerking its head, as if trying to throw off some unpleasant taste."

Certain animals which are without speeial means of defense and are not at all formidable or dangerons are yet so marked or shaped and so behave as to present a threatening or terrifying appearanee. The large green eaterpillars (Fig. 13\%) of the Sphinx moths-the tomato-worm is a familiar one of these larvæ-have a formidable-looking,

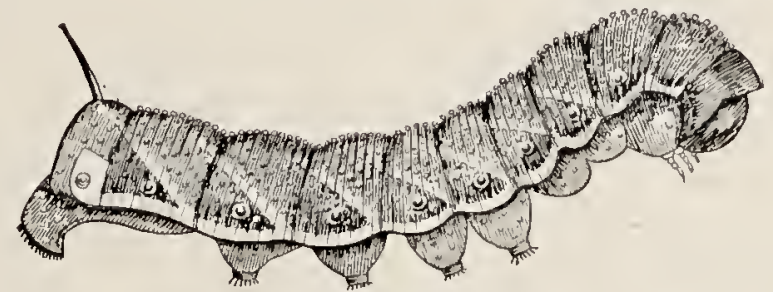

FIG. 13\%.-A "tomato-worm" larva of the Sphinx moth, IMlegethontiks curolina, showing terrifying appearance.

sharp horn on the baek of the next to last body ring. When disturbed they lift the hinder part of the body, bearing the horn, and move it about threateningly. As a matter of fact, the horn is not at all a weapon of defense, but is quite harmless. Numerous insects when disturbed lift the hind part of the body, and by making threatening mo- 
tions lead enemies to believe that they possess a sting. The striking eye-spots of many insects are believed by some entomologists to be of the nature of terrifying appearanees. The larva (Fig. 138) of the Puss moth (C'erura) has been often referred to as a striking example of terrifying appearances. When one of these larvæ is disturbed, "it retraets

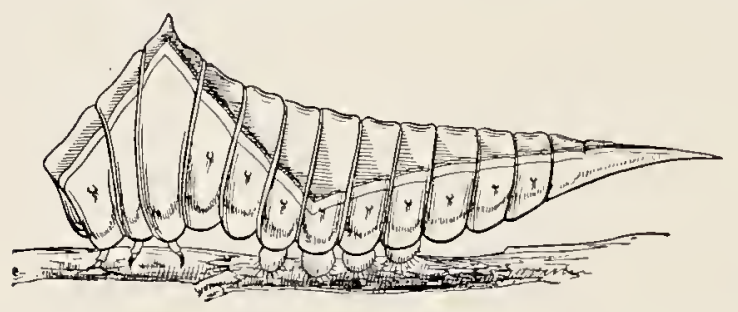
its head into the first body ring inflating the margin. which is of a bright red color. There are two intensely black spots

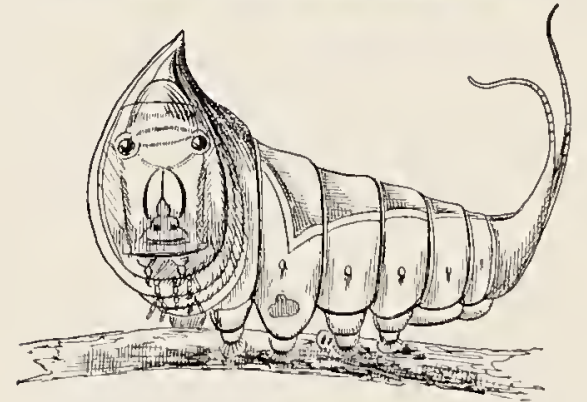

Fig. 138.-Larva of the Puss moth (Cemma).

Upyer figure shows the larva as it apjears when molisturbed; lower fignre, when disturbed.-After loulton.

on this margin in the appropriate position for eyes, and the whole appearanee is that of a large flat face extending to the onter edge of the red margin. The effect is an intensely exaggerated earicatmre of a vertebrate face, which is probably alarming to the vertebrate enemies of the eaterpillar. . . . The effeet is also greatly strengthened by two pink whips which are swiftly protruded from the prongs of the fork in which the body terminates. . . The end of the body is at the same time eurved forward over the back, so that the pink filaments are brandished above the head."

111. Alluring coloration. $-\Lambda$ few animals show what are ealled alluring colors-that is, they display a eolor pattern so arranged as to resemble or mimic a flower or other lure, and thus to entice to them other animals, their natural prey. This is a special kind of aggressive resemblanee. A speeies 
of predatory inseet ealled a "praying-horse" (allied to the genus Mantis), found in India, has the shape and eolor of an orehid. Small inseets are attraeted and fall a prey to it. Certain Brazilian fly-eatehing birds have a brilliantly eolored erest which ean be displayed in the shape of a flower-eup. The inseets attraeted by the apparent flower furnish the flyeateher with food. An Asiatie lizard is wholly colored like the sand upon whieh it lives exeept for a peeuliar red fold of skin at each angle of the mouth. This fold is arranged in flower-like shape, "exactly resembling a little red flower which grows in the sand." Inseets attraeted by these flowers find out their mistake too late. In the tribe of fishes ealled the "anglers" or fishing frogs the front rays of the dorsal fin are prolonged in shape of long, slender filaments, the foremost and longest of which has a flattened and divided extremity like the bait on a hook. The fish conceals itself in the mud or in the eavities of a eoral reef and waves the filaments baek and forth. Small fish are attrated by the lure, mistaking it for worms writhing about in the water or among the weeds. As they approaeh they are ingulfed in the mouth of the angler, which in some of the speeies is of enormous size. One of these speeies is known to fishermen as the "all-mouth." These fishes (Lophius piscatorius), which live in the mud, are eolored like mud or clay. Other forms of anglers, living among coral reefs, are brown and red (Antennurius), their eoloration imitating in minutest detail the markings and outgrowths on the reef itself, the lure itself imitating a worm of the reef. In a eertain group of deep-sea anglers, the seadevils (Ceratiide), certain species show a still further speeialization of the eurious fishing-rod. In one speeies ( $\mathrm{CO}$ rynolophus reinhardti) (Fig. 54), living off the eoast of Greenland at a depth of upward of a mile, the fishing-rod or first dorsal spine has a luminous bulb at its tip around which are fleshy, worm-like streamers. At the abyssal depths of a mile, more or less, frequented by these sea- 
devils there is no light, the inky darkness being absolute. 'This shining lure is therefore a most effective means of securing food.

112. Mimicry.-Although the word mimicry could often have been used aptly in the foregoing account of protective resemblances, it has been reserved for use in connection with a certain specific group of cases. It has been reserved to be applied exclusively to those rather numerous instances where an otherwise defenseless animal, one without poisonfangs or sting, and without an ill-tasting substance in its body, mimics some other specially defended or inedible animal sufficiently to be mistaken for it and so to escape attack. Such cases of protective resemblance are called true mimicry, and they are especially to be observed among insects.

In Fig. 139 are pictured three familial American butterflies. One of these, the Monarch butterfly (Anosia plexippus), is perhaps the most abundant and widespread butterfly of our country. It is a fact well known to entomologists that the Monarch is distasteful to birds and is let alone by them. It is a conspicuons butterfly, being large and chiefly of a red-brown color. The Viceroy butterfly (Basilarchia archipmus), also red-brown and much like the Monarch, is not, as its appearance would seem to indicate, a very near relative of the Monarch, belonging to the same genus, but on the contrary it belongs to the same genus with the third butterfly figured, the black and white Basilarchia. All the butterflies of the genus Basilarchia are black and white except this species, the Viceroy, and one other. 'The Viceroy is not distasteful to birds; it is edible, but it mimics the inedible Monarch so closely that the deception is not detected by the birds, and so it is not molested.

In the tropies there have been discovered numerous sinilar instances of mimicry by edible butterflies of inedible kinds. The members of two great families of butterflies (Danaidse and Ifeliconida) are distasteful to birds, and are 


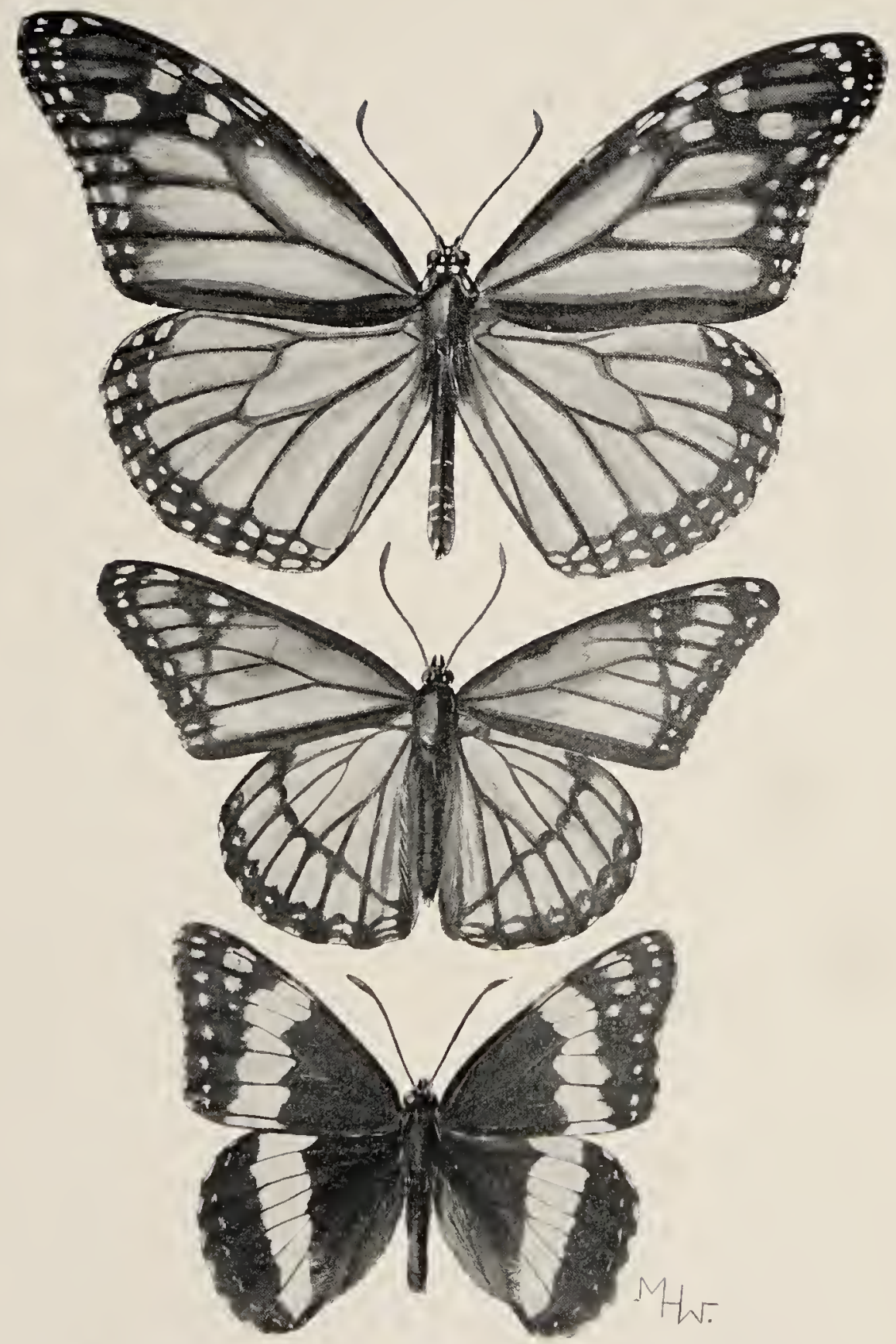

Fig. 139.-The mimicking of the inedible Monarch butterfly by the edible Viceroy. Upper fignre is the Monurch (Anosia Jlexippus); midlle figure is the Ticeroy (Basilarchia archimms); lowest figure is another member of the same cenus (Basilarchia), to show the nsual color pattern of the species of the genus. 
mimieked by members of the other butterfly families (especially the Pieridæ), to which family our eommon white cabbage-butterfly belongs, and by the swallow-tails (Papilionidx).

The bces and wasps are proteeted by their stings. They are usually conspicuous, being banded with yellow and black. 'They are mimicked by numerous other insects, especially moths and flies, two defenseless kinds of inseets. This mimieking of bees and wasps by flies is very common, and can be observed readily at any flowering shrub. The flowerflies (Syrphidx), which, with the bees, visit flowers, can be distinguished from the bees only by sharp observing. When these bees and flies can be caught and examined in hand, it will be found that the flics have but two wings while the bees have four.

A remarkable and interesting ease of mimicry among inseets of different orders is that of eertain South Anerican tree-hoppers (of the family Membraeide, of the order Hemiptera), which mimic the famous leaf-entting ant (Sauba) of the Amazons (Fig. 140). These ants have the curious habit of cutting off, with their sharp jaws, bits of

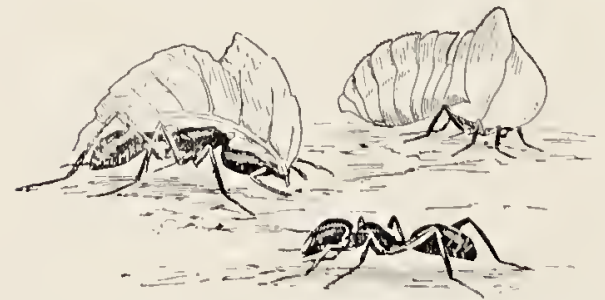

Fia. 140.-Tree-loppere (Memluacider), which mimies the lent-enting ant (Saube) of Brazil. (Uipler right-hand insect is the treehopper.) green leaves and earrying them to their nests. In carrying the bits of lcaves the ants hold them vertically above their heads. The leaf-hopper's mimie the ants and their burdens witl remarkable exactitude by having the back of the body elevated in the form of a thin, jagged-edged ridge no thicker than a leaf. This part of the body is green like the leaves, while the under part of the body and the legs are brown like the ants.

Some examples of mimiery among other animals than 
inseets are known, but not many. The conspicuonsly marked venomous coral-snake or coralillos (Elaps) is mimicked by certain non-venomous snakes called king-snakes (Lampropeltis, Osceola). The pattern of red and black bands surrounding the eylindrical body is perfeetly imitated. But whether this is true mimicry brought about for purposes of proteetion may be doubted. Instances among birds have been described, and a single case has been reeorded in the class of mammals. But it is among the inseets that the best attested instances occur. The simple fact of the close resemblance of two widely rclated animals can not be taken to prove the existence of mimicry. Two animals may both eome to rescmble somc partienlar part in their common environment and thins to rescmble closely eaeh other. Here we have simply two instances of special protective resemblance, and not an instance of mimicry. The student of zoölogy will do well to watel sharply for examples of protective resemblance or mimicry, for but few of the instanees that undoubtedly exist are as yct known.

\section{Protective resemblances and mimicry most common} among insects. - The large majority of the preeeding examples have been taken from among the inseets. 'This is explained by the faet that the phenomena of protective resemblances and mimicry have been studied espceially among insects; the theory of mimicry was worked out ehiefly from the observation and study of the eolors and markings of inscets and of the cconomy of inseet life. Why proteetive rescmblanees and mimicry among insects have been ehicfly studied is because these conditions are speeially eommon among insects. 'The great class Insecta includes more than two thirds of all the known living speeies of animals. The struggle for cxistence among the insects is espeeially severe and bitter. All kinds of "shifts for a living" are pushed to extremes; and as inscet colors and patterns are espeeially varied and conspicuous, it is 
only to be cxpected that this useful modification of colors and patterns, that results in the striking phenomena of special protective rescmblances and mimicry, should be specially widespread and pronouneed among insects. Moreover, they arc mostly deficient in other means of defense, and secm to be the favorite food for many different kinds of animals. Protective resemblance is their best and most widely adopted means of preserving life.

114. No volition in mimicry.-The use of the word mimicry has bcen criticised bccausc it suggests the exereise of volition or intent on the part of the mimieking animal. The student should not entertain this conception of minicry. In the usc of "mimiery" in eonncetion with the phenomena just deseribed, the biologist ascribes to it a technieal meaning, which exeludes any suggestion of volition or intent on the part of the mimie. Just how such extraordinary and perfect cases of mimiery as shown by Plyyllium and Lullima have eome to exist is a problem whose solution is not agreed on by naturalists, but none of them makes volition - the will or intent of the animal-any part of his proposed solution. Each ease of mimicry is the lesult of a slow and gradual change, through a long series of ancestors. The mimicry may indeed include the adoption of certain habits of action which strengthen and make more pronouneed the deception of shape and color. But these habits, too, are the result of a long development, and are instinctive or reflex-that is, performed without the exercise of volition or reason.

115. Color; its utility and beauty.-The eauses of color, and the uses of color in animals and in plants are subjects to which maturalists have paid and are paying much attention. The subjeet of "protective resemblanees and mimicry" is only one, though one of the most interesting, branches or subordinate subjeets of the general theory of the uses of eolor. Other uses are obvious. Bright colors and markings may serve for the attraction of mates; thus 
are explained by some naturalists the brilliant plumage of the male birds, as in the ease of the bird-of-paradise and the pheasants. Or they may serve for recognition eharaeters, enabling the individuals of a band of animals readily to reeognize their eompanions; the eonspieuons whiteness of the short tail of the antelopes and eotton-tail rabbits, the black tail of the black-tail deer, and the white tailfeathers of the meadow-lark, are explained by many naturalists on this ground. Reeognition marks of this type are especially numerous among the birds, hardly a speeies being without one or more of them, if their meaning is eorreetly interpreted. The white eolor of aretic animals may be useful not alone in rendering them inconspieuous, but may serre also a direct physiologieal function in preventing the loss of heat from the body by radiation. And the dark colors of animals may be of value to them in absorbing heat rays and thus helping them to keep warm. But "by far the most widespread use of eolor is to assist an aninal in escaping from its enemies or in eapturing its prey."

The colors of an animal may indeed not be useful to it at all. Many color patterns exist on present-day birds simply because, preserved by heredity, they are handed down by their ancestors, to whom, under different conditions of life, they may have been of direet use. For the most part, however, we can look on the varied colors and the striking patterns exhibited by animals as being in some way or another of real use and value. We can enjoy the exquisite coloration of the wings of a butterfly none the less, however, because we know that these beautiful colors and their arrangement tend to preserve the life of the dainty creature, and have been produced by the operation of fixed laws of Nature working through the ages. 


\section{CHAPTER XIII \\ THE SPECIAL SENSES}

116. Importance of the special senses-The means by which animals beeome aequainted with the onter world are the special senses, such as feeling, tasting, smelling, hearing, and seeing. The behavior of animals with regard to their surroundings, with regard to all the world outside of their own body, depends upon what they learn of this outer world through the exereise of these special senses. Habits are formed on the basis of experience or knowledge of the outer world gained by the speeial senses, and the development of the power to reason or to have sense depends on their pre-existenee.

11\%. Difficulty of the study of the special senses. - We are acenstomed to think of the organs of the special senses as extremely eomplex parts of the body, and this is certainly true in the ease of the higher animals. In our own body the ears and eyes are organs of most specialized and highly developed eondition. But we must not overlook the faet that the amimal kingdom is eomposed of ereatures of widely varying degrees of organization, and that in any eonsideration of matters eommon to all animals those animals of simplest and most lowly organization must be studied as well as those of high development. The study of the speeial senses presents two phases, namely, the study of the strueture of the organs of special sense, and the study of the physiology of speeial sense-that is, the functions of these organs. It will be reeognized that in the study of how other animals feel and taste and smell and hear and 
see, we shall have to base all our study on our own experience. We know of hearing and seeing only by what we know of our own hearing and seeing; but by cxamination of the structure of the hearing and seeing organs of certain other animals, and by observation and cxperiments, zoölogists are convinced that some animals hear sounds that we can not hear, and some see colors that we can not see.

While that phase of the study of the special scnses which concerns their structure may be quite successfully undertaken, the physiological phase of the study of the actual tasting and seeing and hearing of the lower animals is a matter of much difficulty. The condition and character of the special senses vary notably among different animals. There may even exist other special senses than the ones we possess. Some zoölogists believc that certain marine animals possess a "density or pressure sensc"that is, a sense which enables them to tell approximately how deep in the water thcy may be at any time. To certain animals is ascribed a "temperature scnse," and some zoölogists bclieve that what we call the homing instinct of animals as shown by the homing pigcons and honey-bees and other animals, depends on their possession of a special sense which man docs not posscss. Recent experiments, however, secm to show that the homing of pigeons depends on their keen sight. In numerous animals therc exist, besides the organs of the five special scnses which we possess, organs whosc structure compcls us to believe them to be organs of special scnsc, but whose function is wholly unknown to us. Thus in the study of the special senses we are made to sec plainly that we can not rely simply on our knowledge of our own body structure for an understanding of the structure and functions of other animals.

118. Special senses of the simplest animals.-In the Amobe (see Chapter I), that type of the simplest animals, with 
one-celled body, without organs, and yet with its capacity for performing the necessary life processes, there are no special senses except one (perhaps two). The Amoba can feel. It possesses the tactile sense. And there are no special scnse organs except one, which is the whole of the outer surface of the body. If the Amceba be touched with a fine point it feels the touch, for the soft riscous protoplasm of its body flows slowly away from the foreign object. The sense of feeling or tonch, the tactile sense, is the simplest or most primitive of the special senses, and the simplest, most primitive organ of special sense is the outer surface or skin of the body. Among those simple animals that possess the simplest organs of hearing and perceiving light, we shall find these organs to be simply specialized parts of the skin or outer cell layer of the body, and it is a fact that all the special sense organs of all animals are derived or developed from the onter cell layer, ectoblast, of the embryo. This is true also of the whole nervous system, the brain and spinal cord of the vertebrates, and the ganglia and nerve commissures of the invertebrates. And while in the higher animals the nervous system lies mnderneath the surface of the body, in many of the lower, many-celled animals all the ganglia and nerves, all of the nelvous system, lie on the onter surface of the body, being simply a specialized part of the skin.

119. The sense of touch.-In some of the lower, manycelled animals, as among the polyps, there are on the skin certain sense cells, either isolated or in small groups, which seem to be stimulated not alone by the touching of foreign substances, but also by warmth and light. They are not limited to a single special sense. They are the primitive or generalized organs of special sense, and can derelop into specialized organs for any one of the special senses.

The simplest and most widespread of these special senses with, is a whole, the simplest organs, is the tactile 
sense, or the sense of touch. The special organs of this sense are usually simple hairs or papillæ commecting with a nerve. These tactile hairs or papillæ may be distributed pretty evenly over most of the body, or may be mainly collcentrated mpon certain parts in crowded groups. Many of the lower animals liave projecting parts, like the feeling tentacles of many marinc invertebrates, or the antenmæ (feelers) of crabs and insects, which are the special seat of the tactile organs. Among the vertebrates the tactile organs are either like those of the invertebrates, or are little sac-like bodies of connective tissue in which the end of a nerve is curiously folded and convoluted (Fig. 141). These little touch corpuscles simply lie in the cell layer of the skin, covered over thinly by the cuticle. Sometimes they are simply frce, branched nerve-endings in the skin. These tactile corpuscles or free nerve-endings are especially abundant in those parts of the body which can be best used for feeling. In man the finger-tips arc thus espccially supplied; in ccrtain tailed monkeys the tip of the tail, and in hogs the end of the snout. The difference in abundance of these tactile corpuscles of the skin can be rearlily showl by expcriment. With a pair of compasses, whose points have bcen slightly blunted,

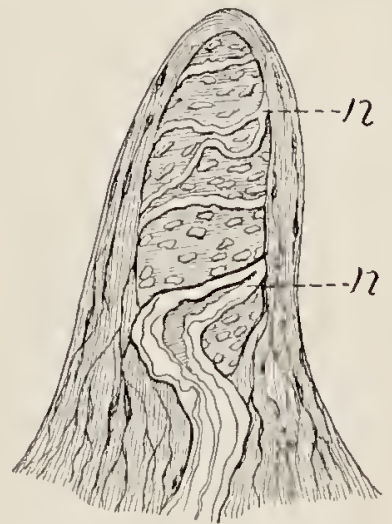

FIt. 141.-Tactile papilla of skin of man. n, nerve. After KOELLISER. touch the skin of the forcarm of a person who has his eyes slut, with the points about threc inches apart and in the direction of the length of the arm. The person touched will feel the points as two. Repeat the touching several times, gradually lessening the distance between the points. When the points are not more than an inch to an inch and a half apart, the person touched will feel but a single tonch-that is, the touching 
of both points will give the sensation of but a single contaet. Repeat the experiment on the tip of the forefinger, and both points will be felt until the points are only about one tenth of an inch apart.

120. The sense of taste.-The sense of taste enables us to test in some degree the chemical constitution of substances whieh are taken into the mouth as food. We diseriminate by the taste organs between good food and bad, well-tasting and ill-tasting. These organs are, with us and the other airbreathing animals, located in the mouth or on the mouth parts. They must be located so as to come into contat with the food, and it is also neeessary that the food substance to be tasted be made liquid. This is aeeomplished by the fluids poured into the mouth from the salivary glands. With the lower aquatic animals it is not improbable that taste organs are situated on other parts of the body besides the mouth, and that taste is used not only to test food substances, but also to test the chemical character of the fluid medium in which they live.

The taste organs are much like the tactile organs, except that the ending of the nerve is exposed, so that small partieles of the substance to be tasted ean come into actual contact with it. The nerve-ending is usnally in a small raised papilla or depressed pit. In the simplest animals there is no special organ of taste, and yet Ameba and other Protozoa show that they appreciate the chemical constitution of the liquid in whieh they lie. They taste-that is, test the elremical constitution of the substanees-by means of their undifferentiated body surface. The taste organs arc not always to be told from the organs of smell. Where an animal has a certain speeial seat of smell, like the nose of the higher animals, then the special sense organs of the mouth ean be fairly assumed to be taste organs; but where the seat of both smell and taste is in the moutl or mouth parts, it is often impossible to distinguish between the two kinds of organs. 
In mammals taste organs are situated on eertain parts of the tongue, and have the form of rather large, low, broad papillæ, each bearing many small taste-buds (Fig. 142). In fishes similar papillæ and buds have been found in various plaees on the surfaee of the body, from whieh it is believed that the sense of taste in fishes is not limited to the mouth. In inseets the taste-papillæ and taste-pits are grouped

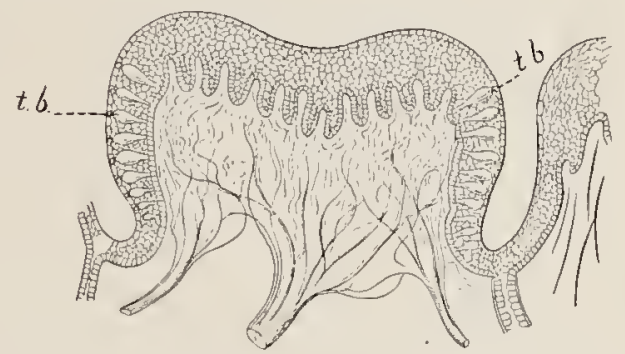
in eertain plaees on the mouth parts, being espeeially abundant on

FIG. 142.-Vertical section of large papilla on tongue of a calf; $t . b$. , taste-buds. - After LOVÉN.

the tips of small, segmented, feeler-like processes ealled palpi, whieh projeet from the under lip and from the soealled maxillæ.

121. The sense of smell._-Smelling and tasting are elosely allied, the one testing substanees dissolved, the other testing substanees vaporized. The organs of the sense of smell are, like those of taste, simple nerve-endings in papillæ or pits. The substanee to be smelled must, however, be in a very finely divided form; it must eome to the organs of smell as a gas or vapor, and not, as to the organs of taste, in liquid condition. The organs of smell are situated usually on the head, but as the sense of smell is used not alone for the testing of food, but for many other purposes, the organs of smell are not, like those of taste, situated prineipally in or near the mouth. Smell is a speeial sense of mueh wider range of use than taste. By smell animals ean diseover food, avoid enemies, and find their mates. They ean test the air they breathe as well as the food they eat. In the matter of the testing of food the senses of both taste and smell are eonstantly used, and are indeed intimately assoeiated. 
The sense of smell varics a great deal in its degree of development in various animals. With the strictly aquatic animals-and these include most of the lower invertebrates, as the polyps, the star-fishes, sea-urchins, and most of the worms and mollusks-the sense of smell is probably but little developed. There is little opportunity for a gas or vapor to come to these animals, and only as a gas or vapor can a substance be smelled. With these animals the sense of taste must take the place of the olfactory sense. But among the insects, mostly terrestrial animals, there is an extraordinary development of the sense of smell. It is indeed probably their principal special sense. Insects must depend on smell far more than on sight or hearing for

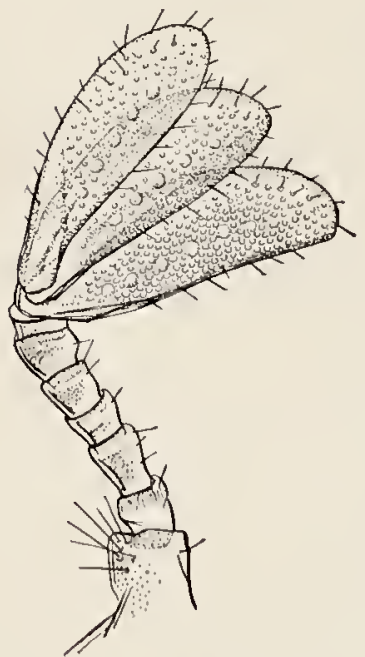

lite. 143.-Autenna of a leateating bectle, showing smelling-puts on the exmundeal terminal segrments. the discovery of food, for becoming aware of the presence of their enemies and of the proximity of their mates and companions. The organs of smell of insects are situated principally on the antcunæ or feelers, a single pair of which is borne on the head of every insect (Fig. 143). That many insects have an extraordinarily keen sense of smell has been shown by numerous experiments, and is constantly proved by well-known habits. If a small bit of dccaying flesh be inclosed in a box so that it is wholly concealed, it will nevertheless soon be found by the flies and carrion beetles that either feed on carrion or must always lay their cggs in decaying matter so that their carrion-eating larve may be provided with food. It is bclieved that ants find their way back to thcir nests by the sense of smell, and that they can recognize by scent among hundreds of individuals taken from various communitics the members of their 
own eommunity. In the insectary at Cornell University, a few years ago, a few females of the beautiful promethea moth (Callosamia promethea) were inclosed in a box, whieh was kept inside the inseetary building. No males had been seen about the insectary nor in its immediate vicinity, although they had been songht for by collectors. A few hours after the beginning of the eaptivity of the female moths there were forty male prometheas fluttering about over the glass roof of the inseetary. They could not

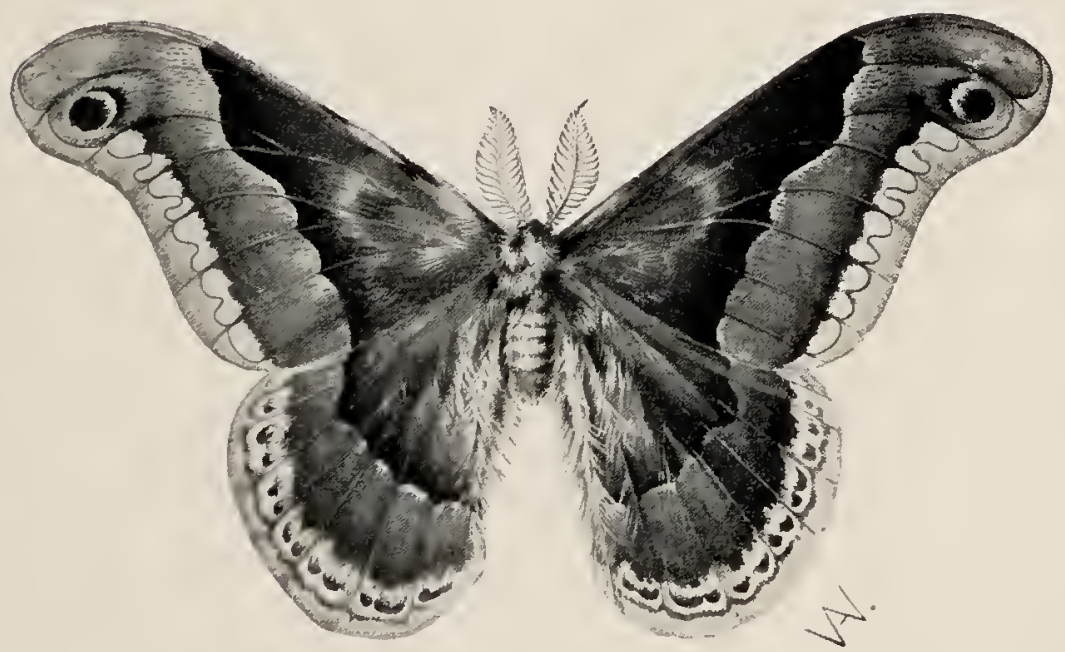

Fig. 141-Promethea moth, male, showing specialized antennie.

see the females, and yet had discorered their presenee in the building. The discovery was undoubtedly made by the scnse of smell. Thesc moths have very elaborately developed antennæ (Fig. 144), finely branehed or feathered, affording opportunity for the existence of very many smelling-pits.

The keenness of scent of hounds and bird dogs is familiar to all, although ever a fresh source of astonishment as we wateh these animals when hunting. We recontly watched a retriever dog select unerringly, by the sense of smell, any partieular duek out of a pile of a hundred. In 
the case of man the sense of smell is not nearly so well developed as among many of the other vertebrates. This inferiority is largely due to degeneration through lessened need; for in Indians and primitive races the sense of smell is keener and better developed than in civilized races. Where man has to make his living by hunting, and has to avoid his enemies of jungle and plain, his special senses are better developed than where the necessity of protection and advantage by means of such keenness of scent and hearing is done away with by the arts of civilization.

122. The sense of hearing.-Hearing is the perception of certain vibrations of bodies. These vibrations give rise to waves-sound waves as they are called-which proceed from the vibrating body in all directions, and which, coming to an animal, stimulate the special auditory or hearing organs, that transmit this stimulation along the auditory nerve to the brain, where it is translated as sound. These sound waves come to animals usually tlirough the air, or, in the case of aquatic animals, through water, or through both air and water.

The organs of hearing are of very complex structure in the case of man and the higher vertebrates. Our ears, which are adapted for perceiving or being stimulated by vibrations ranging from 16 to 40,000 a second-that is, for hearing all those somds produced by vibrations of a rapidity not less than 16 to a second nor greater than 40,000 to a second-are of sucli complexity of structure that many pages would be required for their description. But anong the lower or less highly organized animals the ears, or auditory organs, are much simpler.

In most animals the auditory organs show the common characteristic of being wholly composed of, or having as an essential part, a small sac filled with liquid in which one or lirore tiny spherical hard bodies called ototiths arc held. This auditory sac is formed of or lined internally by 
auditory cells, specialized nerve cells, which often bear delicate vibratile hairs (Fig. 145). Auditory organs of this general character are known among the polyps, the worms, the crustaceans, and the mollusks. In the common crayfish the "ears" are situated in the basal segment of the imner antennæ or feelers (Fig. 146). They eonsist cach of a small sae filled with liquid in which are suspended sevcral grains of sand or other hard bodies. The inner

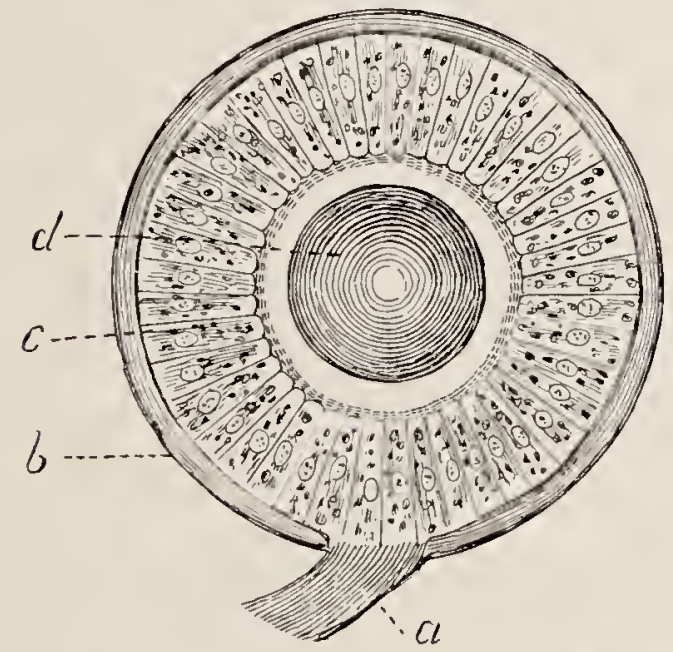

FIc. 145.-Auditory organ of a mollusk. a. auditory nerve: $b$. outer wall of comnoctive tissue; $c$, cells with auditory hairs; $d$, otolith.-After LEYDIG.

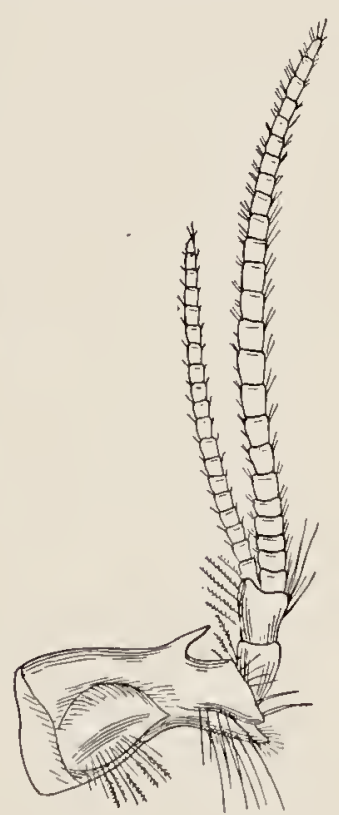

Fig. 146. - Antenua of cray - fish, with auditory sac at base.After IIUXLEY.

surface of the sac is lincd with fine auditory hairs. The sound waves coming through the air or water outside strike against this sac, which lics in a hollow on the upper or outer side of the antennæ. The sound waves arc taken up by the contents of the sae and stimulate the fine hairs, which in turn give this stimulus to the nerves which run from them to the principal anditory nerve and thus to the brain of the cray-fish. Among the insects other kinds of auditory organs cxist. The common locust or grasshopper 
has on the upper surface of the first abdominal segment a pair of tympana or ear-drums (Fig. 14\%), composed simply of the thinned, tightly stretched chitinous

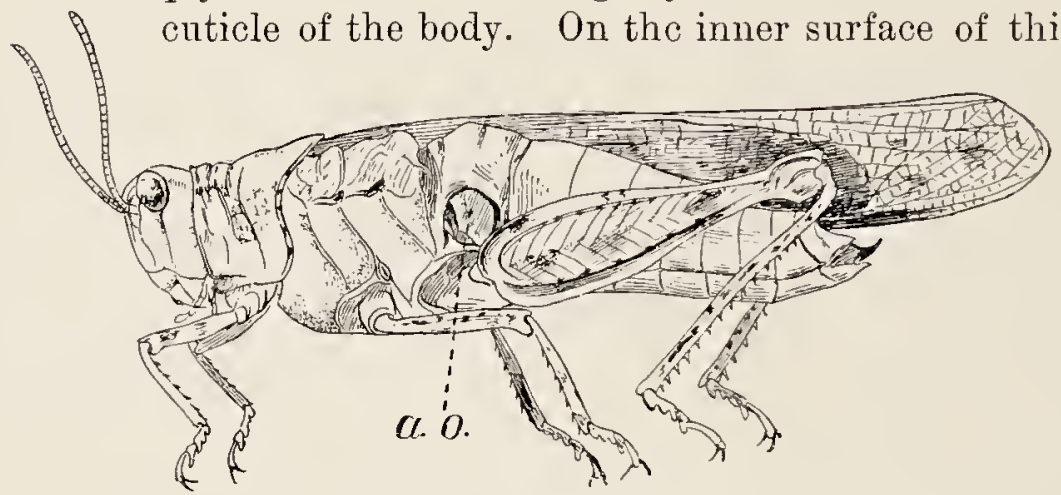

FIG. 14\%-Grasshopper, showing auditory organ (a.o.) in filst segment of abdomen.

(Wings of one side removed.)

ear-drum there are a tiny auditory sac, a fine nerve leading from it to a small auditory ganglion lying near the tympanum, and a large nerve leading from this ganglion to onc of the larger ganglia situated on the floor of the

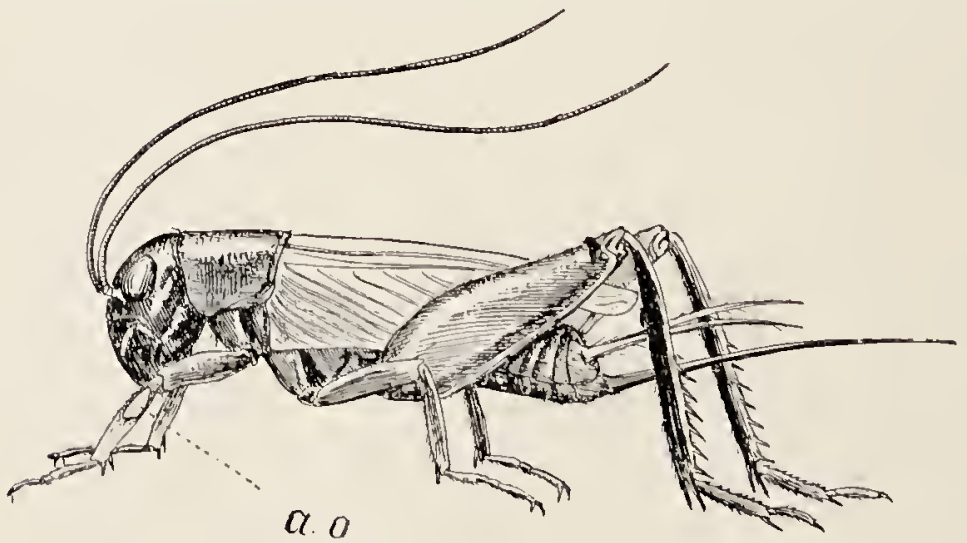

Fu, 14., $-\Lambda$ cricket, showing auditory organ $(a . o$.) in fore-leg.

thorax. In the crickets and katydids, insects related to the locusts, the anditory organs or ears are situated in the fore-legs (Fig. 148).

Certain other inscets, as the mosquitoes and other midges 
or gnats, undoubtedly hear by means of numerous delicate hairs borne on the antennæ. The male mosquitoes (Fig. 149) have many liundreds of thesc long, fine antennal hairs, and on the sounding of a tuning-fork these hairs have been observed to vibrate strongly. In the base of each antenna there is a most elaborate organ, composed of fine chitinous rods, and accompanying nerves and nerve cells whose function it is to take up and transmit through the auditory nerve to the brain the stimuli received from the external auditory hairs.

123. Sound - making. - The sense of hearing enables animals not only to hear the warning natural sounds of storms and falling trecs and plunging avalanches, but the sounds made by each other. Sound-making among animals serves to aid in frightening away enemies or in warning companions of thcir approach,

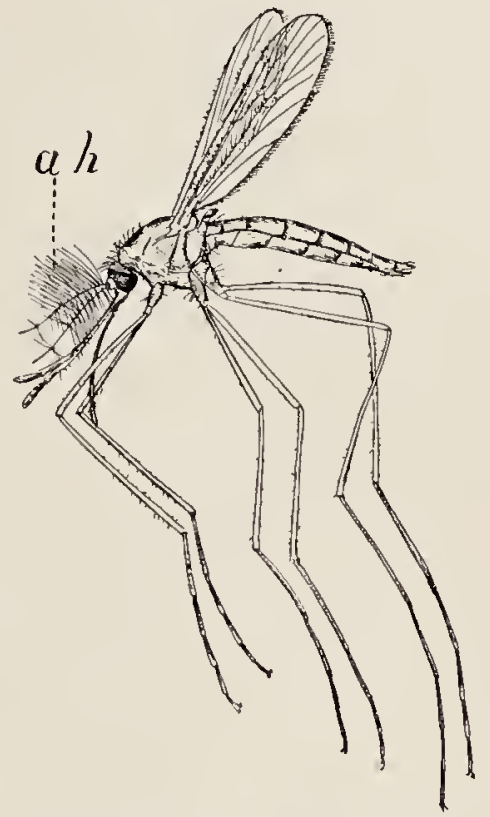

Fra. 149.- A male mosquito, showing auditory hairs $(a . h$.) on the untennie.

\section{for recognition among mates}

and nembers of a band or species, for the attracting and wooing of mates, and for the interchange of information. With the cries and roars of mammals, the songs of birds, and the shrilling and calling of inscets all of us are familiar. These are all sounds that can be heard by the hmman ear. But that there are many sounds made by animals that wc can not hear-that is, that are of too high a pitch for our hearing organs to be stimulated by-is believed by naturalists. Especially is this almost certainly truc in the casc of the inscets. The peculiar sound-producing organs of 
many sound-making inseets are known; but eertain other inseets, whieh make no sound that we ean hear, nevertheless possess similar sound-making organs.

Sound is produeed by mammals and birds by the striking of the air whieh goes to and comes from the lungs against certain vibratory cords or flaps in the air-tubes. Sounds made by this vibration are re-enforced and made louder by arrangements of the air-tubes and mouth for resonanee, and the eharaeter or quality of the sound is modified at will to a greater or less degree by the lips and teeth and other mouth structures. Sounds so made are said to be produeed by a voice, or animals making sounds in this way are said to possess a voice. Animals possessing a voiee have far more range and variety in their soundmaking than most of the animals whieh produee sounds in other ways. The marvelous variety and the great strength of the singing of birds and of the eries and roars of mammals are unequaled by the sounds of any other animals.

But many animals without a roice-that is, whieh do not make sounds from the air-tubes-make sounds, and some of them, as eertain inseets, show mueh variety and range in their singing. The sounds of insects arc made by the rapid vibrations of the wings, as the humming or buzzing of bees and flies, by the passage of air out or into the body through the miny breathing pores or spiraeles (a kind of voice), by the vibration of a stretehed membrane or tympanum, as the loud shrilling of the cieada, and most eommonly by stridulation-that is, by rubbing together two roughened parts of the body. The male criekets and the male katydids rub together the bases of their wing covers to produce thcir shrill singing. 'The loeusts or grasshoppers make sounds when at rest by rubbing the roughened inside of their great leaping legs against the upper surface of their wing eovers, and when in flight by striking the two wings of eaeh side together. Numerous other inseets make sounds by stridulation, but many of 
these sounds are so feeble or so high in piteh that they are rarely heard by us. Certain butterflies make an odd clicking sound, as do some of the watcr-bcetles. In Japan, where small things which are beantiful arc prized not less than large oncs, singing insects arc kept in eages and highly valued, so that their capture beeomes a lucrative industry, just as it is with song birds in Europe and America. Among the many species of Japanese singing insccts is a night ericket, known as the bridle-bit insect, because its note rcsembles the jingling of a bridlc-bit.

124. The sense of sight.-Not all animals have eyes. The moles which live underground, insects, and other animals that live in cares, and the deep-sca fishes which live in waters so deep that the light of the sun nevcr comcs to them, have no eyes at all, or have eyes of so rndimentary a character that they can no longer be used for sceing. But all these eyeless animals have no eyes because they live under eonditions where eyes are useless. Thcy have lost their eyes by degencration. There are, however, many animals that have no eycs, nor have thcy or thcir ancestors ever had eycs. Thesc are the simplest, most lowly organized animals. Many, perhaps all eycless animals are, howcver, eapable of distinguishing light from darkness. They are sensitive to light. An investigator pliced several individuals of the common, tiny fresh-water polyp $(H y d r a)$ in a glass eylinder the walls of which werc painted blaek. He lcft a small part of the cylinder unpainted, and in this part of the cylinder where the light penetrated the Hydras all gathered. The eyeless maggots or larve of flies, when plaeed in the light will wriggle and squirm away into dark crevices. They are eonseious of light when exposed to it, and endeavor to shmm it. Most plants turn thcir leaves toward the light; the sunflowers turn on thcir stems to face the sun. Light seems to stimulate organisms whether they have eyes or not, and the organisms either try to get into the light or to avoid it. But this is not seeing. 
The simplest eyes, if we may eall them eyes, are not eapable of forming an image or picture of external objects. They only make the animal better capable of distinguishing between light and darkness or shadow. Many lowly organized animals, as some polyps, and worms, have eertain eells of the skin speeially provided with pigment. Thesc eells grouped together form what is ealled a pigment fleek, whieh ean, beeause of the presenee of the pigment, absorb more light than the skin cells, and are more sensitive to the light. By such pigment-fleeks, or eye-spots, the animal ean deteet, by their shadows, the passing near them of moving bodies, and thus be in some measure informed of the approach of enemies or of prey. Some of these eye-flecks are provided, not simply with pigment, but with a simple sort of lens that serves to concentrate rays of light and

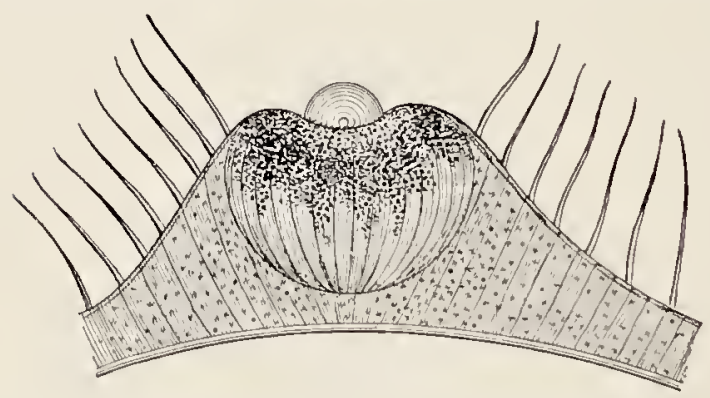

Fra. 150.-The simple eye of a jelly-fish (Lizzia koellikeri).-After O. and R. HERTwig.

make this simplest sort of eye even more scnsitive to ehanges in the intensity of light (Fig. 150).

Most of the many-eelled animals possess eyes by mcans of whieh a picture of external objects morc or less nearly conplcte and perfect can be formed. There is great variety in the fincr strueture of these pieture-forming eyes, but caeh consists essentially of an inner delicate or sensitive ncrvous surfaee ealled the retina, which is stimulated by light, and is comneeted with the brain by a large optic nerve, and of a transparent lightrefrating lens lying outside of the retina and cxposed to the light. 'Thesc arc the eonstant essential parts of an image-forming and image-percciving eye. In most cyes there are other accessory parts which may make the whole. 
eye an organ of excessively complicated structure and of remarkably perfect seeing capacity. Our own eyes are organs of extreme structural complexity and of high development, although some of the other vertebratcs have undoubtedly a keener and more nearly perfected sight.

The crustaceans and insects have cyes of a peculiar character called compound eyes. In addition most insects have smaller simple cyes. Each of the compound eycs is composed of many (from a few, as in ccrtain ants, to as many as twenty-five thousand, as in certain beetles) eye elements, cach eye element seeing independently of the other eye elemcnts and seeing only a very small part of any object in front of the whole eye. All thesc small parts of the external object seen by the many distinct eye elements are combined so as to form an image in mosaic-that is, made up of separate small parts-of the extcrnal object.

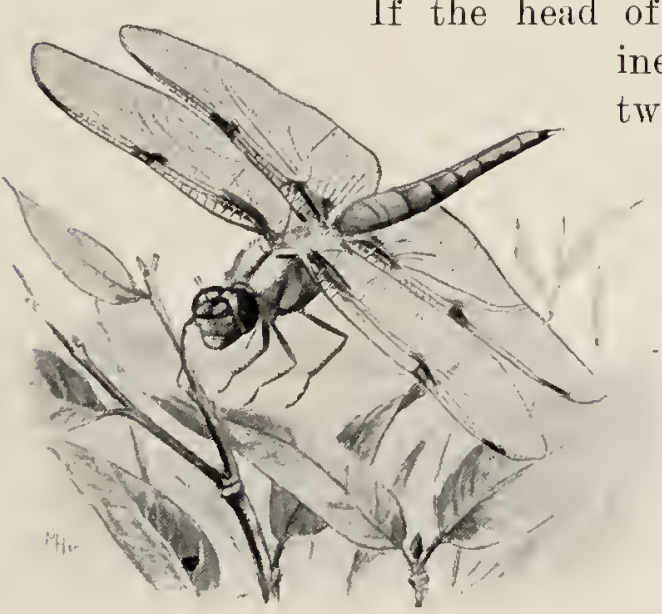

F1G. 151.-A dragon-fly, showing the large compomd eyes on the head. ined, it will be seen that two thirds or more of the

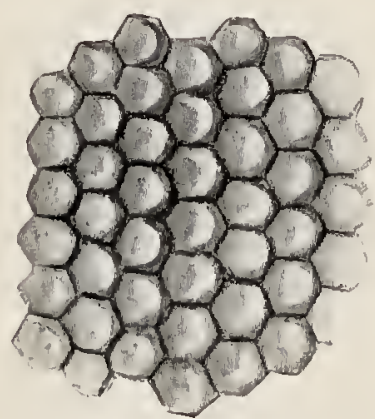

Fis. 15\%.- Some of the ficets of the compound eye of a dragon-fly.

whole head is madc up of the two large compound cyes (Fig. 151), and with a lens it may be scen that the outer surface of cach of these eycs is composed of many small spaces or facets (Fig. 152) which are the outer lenses of the many eye elements composing the wholc eye. 


\section{CHAPTER XIV \\ INSTINCT AND REASON}

125. Irritability.-All animals of whatever degree of organization show in life the quality of irritability or response to external stimulus. Contact with external things produces some effect on each of them, and this effect is something more than the mere meehanical effect on the matter of which the animal is composed. In the onecelled animals the functions of response to external stimulus are not localized. They are the property of any part of the protoplasm of the body. Just as breathing or digestion is a funetion of the whole cell, so are sensation and response in action. In the higher or many-eelled animals eaeh of these functions is specialized and localized. A eertain set of eells is set apart for each function, and each organ or series of eells is released from all funetions save its own.

126. Nerve cells and fibers.-In the development of the individual animal eertain eells from the primitive external layer or ectoblast of the embryo are set apart to preside over the relations of the ereature to its environment. These eells are highly specialized, and while some of them are highly sensitive, others are adapted for earrying or transmitting the stimuli reeeired by the sensitive eclls, and still others have the function of receiving sense-impressions and of translating them into impulses of motion. The nerve cells are receivers of impressions. 'These are gathered together in nerve masses or ganglia, the largest of these being known as the brain, the ganglia in general being known as nerve eenters. 'The nerves are of two elasses. 
The one elass, ealled sensory nerves, extends from the skin or other organ of sensation to the nerve eenter. The nerves of the other elass, motor nerves, earry impulses to motion.

127. The brain or sensorium. - The brain or other nerve eenter sits in darkness surrounded by a bony proteeting box. To this main nerve eenter, or sensorium, eome the nerves from all parts of the body that have sensation, the external skin as well as the speeial organs of sight, hearing, taste, smell. With these eome nerves bearing sensations of pain, temperature, museular effort-all kinds of sensation whieh the brain ean reeeive. These nerves are the sole sourees of knowledge to any animal organism. Whatever idea its brain may eontain must be built up through these nerve impressions. The aggregate of these impressions eonstitute the world as the organism knows it. All sensation is related to aetion. If an organism is not to aet, it ean not feel, and the intensity of its feeling is related to its power to aet.

128. Reflex action.-These impressions brought to the brain by the sensory nerves represent in some degree the faets in the animal's environment. They teaeh something as to its food or its safety. The power of locomotion is eharaeteristie of animals. If they move, their aetions must depend on the indieations earried to the nerve eenter from the outside; if they feed on living organisms, they must seek their food; if, as in many eases, other living organisms prey on them, they must bestir themselves to eseape. The impulse of hunger on the one hand and of fear on the other are elemental. The sensorium reeives an impression that food exists in a eertain direction. At onee an impulse to motion is sent out from it to the museles necessary to move the body in that direetion. In the higher animals these movements are more rapid and more exact. This is beeause organs of sense, museles, nerve fibers, and nerve eells are all alike highly speeialized. In the star-fish the sensation is slow, the museular response sluggish, but the 
method remains the same. This is simple reflex action, an impulse from the environment carried to the brain and then unconsciously reflected back as motion. The impulse of fear is of the same nature. Strike at a dog with a whip, and he will instinctively shrink away, perhaps with a cry. Perhaps he will leap at you, and you unconsciously will try to escape from him. Reflex action is in general unconscious, but with animals as with man it shades by degrees into conscious action, and into volition or action "done on purpose."

129. Instinct.-Different one-celled animals show differences in method or degree of response to external influences. The feelers of the Amoba will avoid contact with the feelers or pseudopodia of another Amoba, while it does not shrink from contact with itself or with an organism of unlike kind on which it may feed. Most Protozoa will discard grains of sand, crystals of acid, or other indigestible object. Such peculiarities of different forms of life constitute the basis of instinct.

Instinct is antomatic obedicnce to the demands of extemal conditions. As these conditions vary with each kind of animal, so must the demands vary, and from this arises the great varicty actually seen in the instincts of different animals. As the demands of life become complex, so may the instinets become so. The greater the stress of enviromment, the more perfect the antomatism, for impulses to safo action are necessarily adequate to the duty they have to perform. If the instinct were inadequate, the species would have become extinct. The fact that its individuals persist shows that they are provided with the instincts nccessaly to that end. Instinct differs from other allied forms of response to external condition in being hereditary, continuous from generation to generation. This sufficiently distinguishes it from reason, but the line between instinct and reason and other forms of reflex action can not be sharply diawn. 
It is not neeessary to eonsider here the question of the origin of instinets. Some writers regard them as "inherited habits," while others, with apparent justiee, doubt if mere habits or voluntary aetions repeated till they beeome a "seeond nature" ever leave a traee upon heredity. Sueh investigators regard instinet as the natural survival of those methods of automatic response whieh were most useful to the life of the animal, the individuals having less effeetive methods of reflex aetion having perished, leaving no posterity.

An example in point would be the homing instinet of the fur-seal. When the aretie winter deseends on its home in the Pribilof Islands in Bering Sea, these animals take to the open ocean, many of them swimming southward as far as the Santa Barbara Islands in California, more than three thousand miles from home. While on the long swim they never go on shore, but in the spring they return to the northward, finding the little islands hidden in the aretie fogs, often landing on the very spot from whieh they were driven by the iee six months before, and their arrival timed from year to year almost to the same day. The perfeetion of this homing instinet is vital to their life. If defeetive in any individual, he would be lost to the herd and would leave no deseendants. Those who return beeome the parents of the herd. As to the others the rough sea tells no tales. We know that, of those that set forth, a large pereentage never comes baek. To those that return the homing instinet has proved adequate. This must be so so long as the raee exists. The failure of instinet would mean the extinetion of the species.

130. Classification of instincts. - The instinets of animals may be roughly elassified as to their relation to the individual into egoistie and altruistie instinets.

Egoistic instinets are those whieh eoneern ehiefly the individual animal itself. To this elass belong the instinets of feeding, those of self-defense and of strife, the instinets 
of play, the climatie instinets, and environmental instincts, those which direct the animal's mode of life.

Altruistic instincts arc those which relate to parenthood and those which are eoneerned with the mass of indi-Dokck viduals of the same species. The latter may be called the soeial instincts. In the former class, the instincts of parenthood, may be included the instinets of eourtship, reproduction, home-making, nest-building, and care for the young.

131. Feeding. - The instincts of feeding are primitively simple, growing complex through eomplex conditions. The protozoan absorbs smaller ereatures whieh contain nutriment. The sea-anemone eloses its tentacles over its prey. The barnaele waves its feelers to bring edible ereatures within its mouth. The fish seizes its prey by direet motion. The higher vertebrates in general do the same, but the conditions of life modify this simple action to a very great degree.

In general, animals deeide by reflex actions what is suitable food, and by the same proeesses they rejcet poisons or unsuitable substanecs. The dog rejeets an apple, while the horse rejeets a pieee of meat. Either will turn away from an offered stone. Almost all animals rejeet poisons instantly. Those who fail in this regard in a state of nature die and leave no descendants. The wild retehes or "loco-weeds" of the arid regions affect the nerve centers of animals and eause dizziness or death. The native ponies rejeet these instinetively. This may be because all ponies whieh have not this reflex dislike have been destroyed. The imported horse has no sueh instinet and is poisoned. Very few animals will cat any poisonous objeet with which their instincts are familiar, mnless it be concealed from smell and taste.

In some cases, very elaborate instincts arisc in eonnection with feeding habits. With the California woodpeckers (Melanerpes formicivorus bairlii) a large number of them 
together seleet a live-oak tree for their operations. They first bore its bark full of holes, eaeh large enough to hold an aeorn. Then into eaeh hole an aeorn is thrust (Figs. 61 and 62). Only one tree in several square miles may be seleeted, and when their work is finished all those interested go about their business elsewhere. At irregular intervals a dozen or so eome baek with mueh elamorous discussion to look at the tree. When the right time eomes, they all return, open the aeorns one by one, devouring apparently the substanee of the nut, and probably also the grubs of beetles whieh lave developed within. When the nuts are ripe, again they return to the same tree and the same proeess is repeated. In the tree figured this has been notieed eaeh year sinee 1891 .

132. Self-defense.-The instinet of self-defense is even more raried in its manifestations. It may show itself either in the impulse to make war on an intruder or in the desire to flee from its enemies. Among the flesh-eating mammals and birds fiereeness of demeanor serves both for the seenring of food and for proteetion against enemies. The stealthy movements of the lion, the skulking habits of the wolf, the sly selfishness of the fox, the blundering goodnatured power of the bear, the groediness of the hyena, are all proverbial, and similar traits in the eagle, owl, hawk, and vulture are seareely loss matters of eommon observation.

Herbivorous animals, as a rule, make little direet resistanee to their enemies, depending rather on swiftness of foot, or in some eases on simple insignifieanee. To the latter eause the abundanee of miee and mouse-like rodents may be attributed, for all are the prey of earnivorous beasts and birds, and even snakes.

Even young animals of any speeies show great fear of their hereditary enemies. The nestlings in a nest of the Ameriean bittern when one week old showed no fear of man, but when two weeks old this fear was very inanifest 
(Figs. 153 and 154). Young mooking-birds will go into spasms at the sight of an owl or a eat, while they pay little attention to a dog or a hen. Monkeys that have nerer seen a snake show almost hysterical fear at first sight of one, and the same kind of feeling is common to most men. A monkey was allowed to open a paper bag which

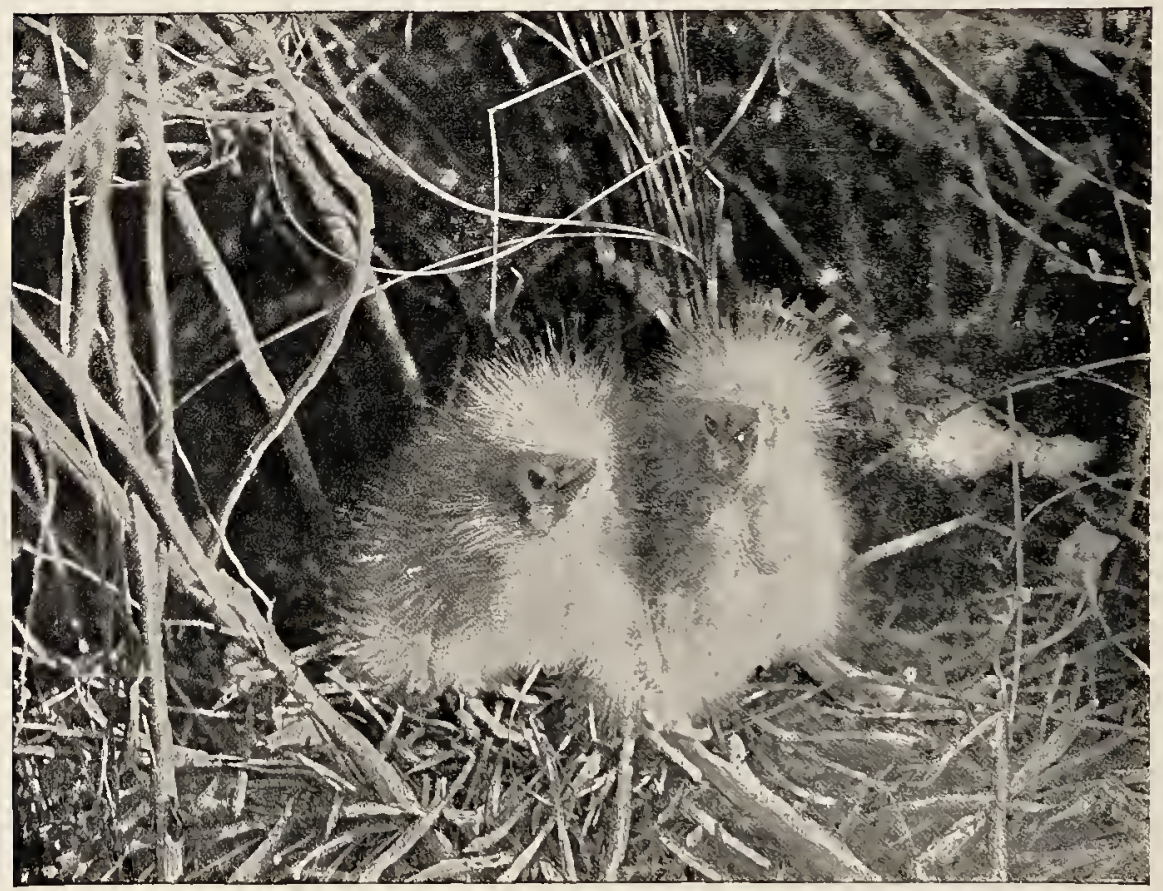

Fia. 153.-Nestlings of the American bittern. Two of a brood of four birds one week old, at which age they showed no fear of man. Photograph by E. II. TABor, Meridian. N. Y., May 31, 1898. (Permission of Macmillan Company, publishers of Bird-1,ore.)

contained a live smake. He was staggered by the sight, but after a while went baek and looked in again, to repeat tho exporienee. Each wild animal has its special instinet of resistance or method of keeping off its enemies. The stamping of a sheep, the kicking of a horse, the ruming in a circle of a hare, and the skulking in a cirole of some foxes, are examples of this sort of instinet. 
133. Play.-The play instinct is developed in numerous animals. To this class belong the wrestlings and mimic fights of young dogs, bear cubs, seal pups, and young beasts generally. Cats and kittens play with miee. Squir-

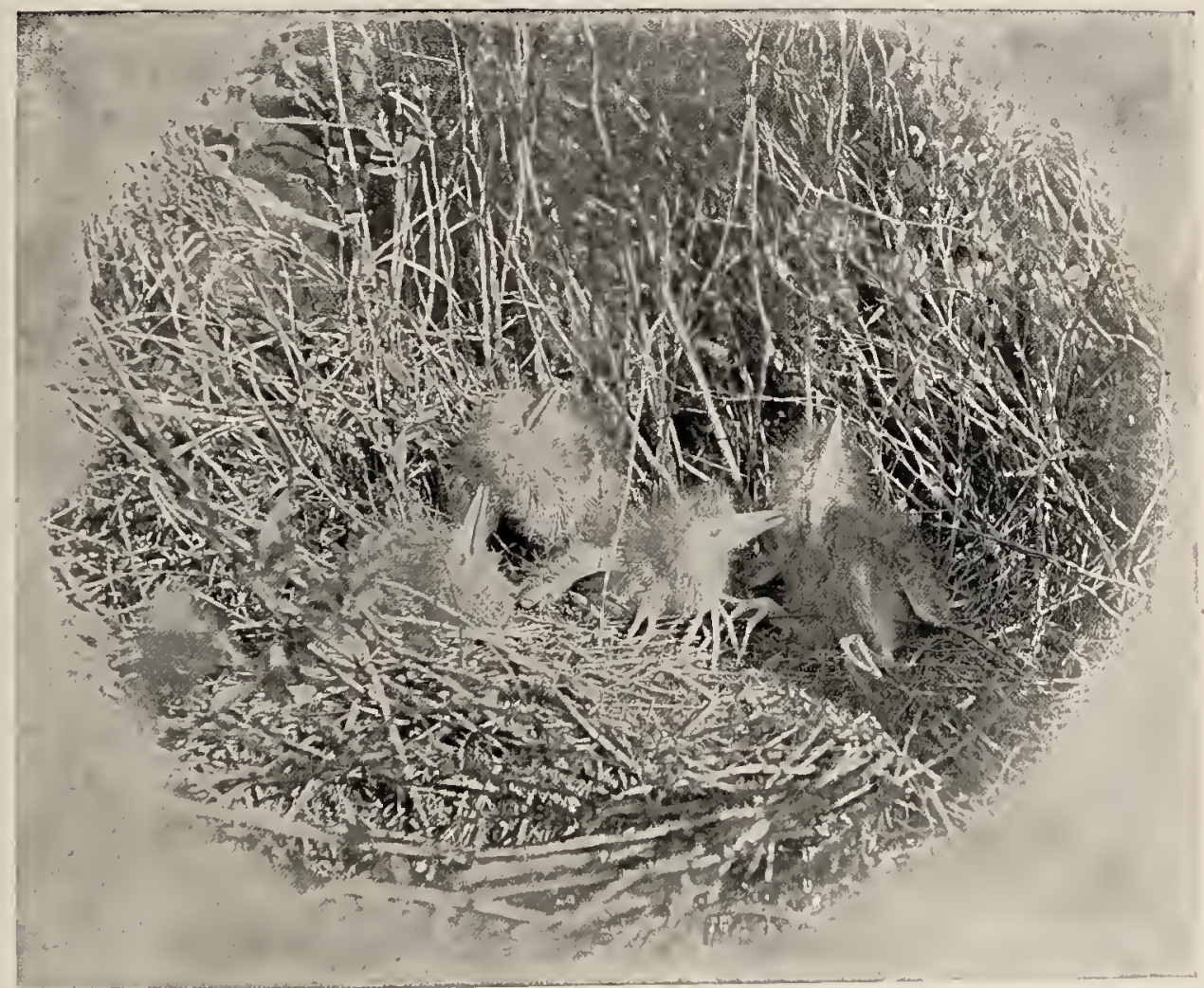

FIG. 154.-Nestlings of the American bittern. The four members of the brood of which two are shown in Fig. 153. two weeks old, when they showed marked four of man. Photograph by F. M. Chapran, Meridian, N. Y., June 8, 1898. (1'ermission of Macmillan Company, publishers of Bird-Lore.)

rels play in the trees. Perhaps it is the play impulse which leads the shrike or buteher-bird to impale small birds and beetles on the thorns about its nest, a ghastly kind of orrument that seems to eonfer satisfaction on the bird itself. The talking of parrots and their imitations of the sounds they hear seem to be of the nature of play. The greater 
their superflnous energy the more they will talk. Much of the singing of birds, and the crying, calling, and howling of other animals, are mere play, although singing primarily belongs to the period of reproduction, and other calls and eries result from social instincts or from the instinct to eare for the young.

134. Climate.-Chimatic instincts are those which arise from the ehange of seasons. When the winter eomes the fur-scal takes its long swim to the sonthward; the wild gecse range themselves in wedge-shaped lloeks and fly high and far, ealling loudly as they go; the bobolinks straggle away one at a time, flying mostly in the night, and most of the smaller birds in cold countries move away toward the tropics. All these movements spring from the migratory instinct. Another elimatie instinct leads the bear to hide in a cave or hollow tree, where he slceps or hibcrnates till spring. In some cases the climatie instinet merges in the homing instinet and the instinet of reproduction. When the birds move north in the spring they sing, mate, and build their nests. The fnr-seal goes home to rear its young. The bear exehanges its bed for its lair, and its first business after waking is to make ready to rear its young.

135. Environment.-Environmental instinets eoncer'n the ercature's mode of life. Such are the burrowing instincts of ecrtinin rodents, the woodehneks, gophers, and the like. 'To enumerate the chief phases of sueh instinets would be diffieult, for as all animals are related to their environment, this relation mnst show itself in eharacteristic instinets.

136. Courtship.-The instinets of courtship relate ehiefly to the male, the female being more or less passive. Among many fishes the male struts before the female, spreading his fins, intensifying his pigmented eolors throngh musenlar tension, and in sueh fashion as he can makes himself the preferred of the female. In the little brooks in spring male minnows can be found with warts on the nose or head, 
with crimson pigment on the fins, or blue pigment on the back, or jet-black pigment all over the head, or with varied combinations of all these. Their instinct is to display all these to the best advantage, even though the conspicuous hues lead to their own destruction. Against this contingency Nature provides a superfluity of males.

Among the birds the male in spring is in very many species provided with an orramental plumage which he sheds when the breeding season is over. The scarlet, crimson, orange, blue, black, and lustrous colors of birds are commonly seen only on the males in the breeding season, the young males and all males in the fall having the plain brown gray or streaky colors of the female. Among the singing birds it is chiefly the male that sings, and his voice and the instinct to use it are commonly lost when the young are hatched in the nest.

Among polygamous mammals the male is usually much larger than the female, and his courtship is often a struggle with other males for the possession of the female. Among the deer the male, armed with great horns, fight to the death for the possession of the female or for the mastery of the herd. 'The fur-seal has on an average a family of about thirty-two females (Fig. 71 ), and for the control of his harem others are ready at all times to dispute the possession. But with monogamous animals like the true or hair seal or the fox, where a male mates with a single female, there is no such discrepancy in size and strengtl, and the warlike force of the male is spent on outside enemies, not on his own species.

13\%. Reproduction. - The movements of many migratory animals are mainly controlled by the impulse to reproduce. Some pelagic fishes, especially flying-fislıes and fishes allied to the mackerel, swim long distances to a region favorable for a deposition of spawn. Some species are known only in the water's they make their breeding homes, the individuals being scattered through the wide seas at 
other times. Many fresh-water fishes, as trout, suckers, etc., forsake the large streams in the spring, ascending the small brooks where they can rear their young in greater safety. Still others, known as anadromous fishes, feed and mature in the sea, but ascend the rivers as the impulse of reproduction grows strong. Among such specics are the salmon, shad, alewifc, sturgeon, and striped bass in American waters. The most noteworthy case of the anadromous instinct is found in the king salmon or quimat of the Pacific coast. This great fish spawns in Norember. In the Columbia River it begins running in March and April, spcnding the whole summer in the ascent of the river without feeding. By antumn the individuals are greatly changed in appearance, discolored, worn, and distorted. On reaching the spawning beds, some of them a thousand miles from the sea, the female deposits her cggs in the gravel of some shallow brook. After they are fertilized both male and fomale drift tail foremost and helpless down the strcam, none of them ever surviving to reach the sea. The same habits are found in other species of salmon of the Pacific, but in most cases the individuals of other specics do not start so early or run so far. A few species of fishes, as the cel, reverse this order, fceding in the rivers and brackish creeks, dropping down to the sea to spawn.

The migration of birds has relation to reproduction as well as to changes of weather. As soon as they reach their summer homes, courtship, mating, nest-building, and the cure of the young occupy the attention of crery species.

138. Care of the young.-In the animal kingdom one of the great factors in development has been the care of the young. 'This feature is a promincht one in the specialization of birds and mammals. When the young are cared for the percentage of loss in the struggle for life is greatly reduced, the number of births necessary to the maintenance of the species is much less, and the opportunitics for specialization in other relations of life are much grcater. 
In these regards, the nest-building and home-making animals have the advantage over those that have not these instincts. The animals that mate for life have the advantage over polygamous animals, and those whose social or mating habits give rise to a division of labor over those with instincts less highly specialized.

The interesting instincts and habits connected with nest or home building and the care of the young are discussed in the next chapter.

139. Variability of instincts. - When we study instincts of animals with care and in detail, we find that their regularity is much less than has bcen supposed. Therc is as much variation in regard to instinct among individuals as there is with regard to other characters of the spccies. Some power of choice is found in almost every operation of instinct. Even the most machinc-like instinct shows some degree of adaptability to new conditions. On the other hand, in no animal does reason show entire frecdom from antomatism or reflex action. "The fundamental identity of instinct with intelligence," says an able investigator, "is shown in their dependence upon the same structural mechanism (the brain and nerves) and in their responsive adaptability."

140. Reason.-Reason or intellect, as distinguished from instinct, is the choice, more or less conscious, among responses to external impressions. Its basis, like that of instinct, is in reflex action. Its operations, often repeated, become similarly reflex by repetition, and are known as habit. A habit is a voluntary action repeated until it becomes reflex. It is essentially like instinct in all its manifestations. The only evident difference is in its origin. Instinct is inherited. Habit is the reaction produced witlin the individual by its own repeated actions. In the varied relations of life the pure reflex action becomes inadequate. The sensorium is offered a choice of responses. To choose one and to reject the others is the function of intel- 
lect or reason. While its excessive development in man obscures its close relation to instinct, both shade off by degrees into reflex action. Indeed, no sharp line ean be drawn between unconseious and subconseious choice of reaction and ordinary intellectual processes.

Most animals have little self-eonsciousness, and their reasoning powers at best are of a low order; but in kind, at least, the powers are not different from reason in man. A horse reaches over the fenee to be company to another. This is instinct. When it lets down the bars with its teeth, that is reason. When a dog finds its way home at night by the sense of smell, this may be instinct; when he drags a stranger to his wounded master, that is reason. When a jack-rabbit leaps over the brush to escape a dog. or runs in a circle before a coyote, or when it lies flat in the grass as a round ball of gray indistinguishable from grass, this is instinct. But the same animal is capable of reason-that is, of a distinct choice among lines of aetion. Not long ago a rabbit came bounding across the university campus at Palo Alto. As it passed a corncr it suddenly faced two hunting dogs ruming side by side toward it. It had the choice of turning back, its first instinct, but a dangerous one; of leaping over the dogs, or of lying flat on the ground. It chose none of these, and its choiee was instantaneons. It ceased leaping, lan low, and went between the dogs just as they were in the aet of seizing it, and the surprise of the dogs, as they stopped and tried to hurry around, was the same feeling that a man would have in like eiremmstanees.

On the open plains of Mereed County, California, the jack-rablit is the prey of the bald eagle. Not long sinee a rabbit pursmed by an eagle was seen to rum among the cattle. Leaping from cow to cow, he used these animals as a shelter from the savage bird. When the pursuit was closer, the rabbit broke cover for a barbed wire fenee. When the eagle swooped down on it, the rabbit moved a few inches to the right, and the eagle eould not reach him 
through the fence. When the eagle came down on the other side, he moved across to the first. And this was continued until the eagle gave up the chase. It is instinet that leads the eagle to swoop on the rabbit. It is instinet again for the rabbit to run away. But to rm along the line of a barbed wire fence demands some degree of reason. If the need to repeat it arose often in the lifetime of a single rabbit it would become a habit.

The difference between intelleet and instinet in lower animals may be illustrated by the conduet of eertain monkeys brought into relation with new experienees. At one time we had two adult monkeys, "Bob" and "Joeko," belonging to the genus Macacus. Neither of these possessed the egg-eating instinet. At the same time we had a baby monkey, "Mono," of the genus Cercopithecus. Mono had never seen an egg, but his inherited impulses bore a direct relation to feeding on eggs, just as the lieredity of Macacus taught the others how to eraek nuts or to peel fruit.

To each of these monkeys we gave an egg, the first that any of them had ever seen. The baby monkey, Mono, being of an egg-eating race, devoured his egg by the operation of instinct or inherited habit. On being given the egg for the first time, he cracked it against his upper teeth, making a hole in it, and sucked out all the substanee. Then holding the egg-shell up to the light and seeing that there was no longer anything in it, he threw it away. All this he did meehanically, automatieally, and it was just as well done with the first egg he ever saw as with any other he ate. All eggs sinee offered him he has treated in the same way.

The monkey Bob took the egg for some kind of nut. He broke it against his npper teeth and tried to pull off the shell, when the inside ran out and fell on the ground. He looked at it for a moment in bewilderment, took both hands and scooped up the yolk and the sand with whieh it was mixed and swallowed the whole. Then he stuffed the 
shell itself into his mouth. This aet was not instinetive. It was the work of pure reason. Evidently his raee was not familiar with the use of eggs and had aequired no instinets regarding them. He would do it better next time. Reason is an ineffieient agent at first, a weak tool; but when it is trained it beeomes an agent more valuable ard more powerful than any instinet.

The monkey Joeko tried to eat the egg offered him in mueh the same way that Bob did, but, not liking the taste, he threw it away.

The eonfusion of highly perfeeted instinet with intelleet is very eommon in popular disenssions. Instinet grows weak and less aecurate in its antomatie obedience as the intelleet beeomes available in its plaee. Botl intelleet and instinet are outgrowths from the simple reflex response to external eonditions. But instinet insures a single definite response to the eorresponding stimulus. The intelleet has a ehoiee of responses. In its lower stages it is vaeillating and ineffeetive; but as its development goes on it beeomes alert and adequate to the varied eonditions of life. It grows with the need for improvement. It will therefore beeome impossible for the eomplexity of life to outgrow the adequacy of man to adapt himself to its eonditions.

Many animals enrrently believed to be of high intelligenee are not so. 'The fur-seal, for example, finds it way back from the long swim of two or three thousand miles through a foggy and stomy sea, and is never too late or too early in arrival. The female fur-seal goes two hundred miles to her feeding grounds in summer, leaving the pup on the shore. After a week or two she returns to find him within a few rods of the roeks where she had left him. Both mother and young know each other by eall and by odor, and neither is ever mistaken, though ten thousand other pups and other mothers oeeupy the same rookery. But this is not intelligenee. It is simply instinct, beeanse it has no element of choice in it. Whatever its aneestors 
were forced to do the fur-seal does to perfection. Its instincts are perfect as clockwork, and the necessities of migration must keep them so. But if brought into new conditions it is dazed and stupid. It can not choose when different lines of action are presented.

The Bering Sea Commission once made an experiment on the possibility of separating the young male fur-seals, or "killables," from the old ones in the same band. The method was to drive them through a wooden chute or runway with two valve-like doors at the end. These animals can be driven like sheep, but to sort them in the way proposed proved impossible. The most cxperienced males would beat their noses against a closed door, if they had seen a scal before them pass through it. That this door had bcen shut and another opened beside it passed their comprehcnsion. They could not choosc the new direction. In like manner a malc fur-seal will watch the killing and skinning of his mates with perfect composure. He will sniff at their blood with langnid curiosity; so long as it is not his own it does not matter. That his own blood may flow ont on the ground in a minute or two he can not foresee.

Reason arises from the neccssity for a choice among actions. It may arise as a clash among instincts which forces on the animal the neccssity of choosing. A doe, for cxample, in a rich pasture has the instinct to feed. It hears the hounds and lias the instinct to flee. Its fawn may be with her and it is her instinct to remain and protect it. This may be done in onc of several ways. In proportion as the mother clooses wisely will be the fawn's chance of survival. Thus under difficult conditions, reason or choicc among actions rises to the aid of the lowcr animals as well as man.

141. Mind.-The word mind is popularly used in two different senses. In the biological sense the mind is the collective name for the functions of the sensorium in men and animals. It is the sum total of all psychic changes, 
aetions and reactions. Under the head of psyehie funetions are included all operations of the nervous system as wcll as all functions of like nature which may exist in organisms without speeialized nerve fibers or nerve eells. As thus dcfincd mind would inelude all phenomena of irritability, and even plants have the rudiments of it. The operations of the mind in this sensc need not be conscious. With the lower animals almost all of them are automatic and uneonscious. With mall most of them must be so. All funetions of the sensorium, irritability, reflex action, instinct, rcason, volition, are alike in essential nature though differing greatly in their degrec of specialization.

In another sense the term mind is applied only to eonscious reasoning or conscious rolition. In this sense it is mainly an attribute of man, the lower animals showing it in but slight degrec. The diseussion as to whether lower animals have minds turns on the definition of mind, and our answer to it depends on the definition we adopt.

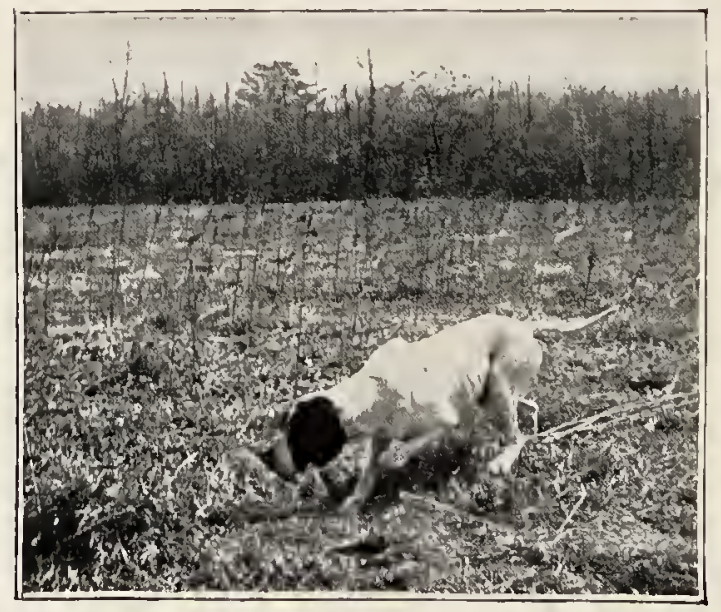

FIG. 155. -A "pointer" dog in the act of "pointing." a specialized instinct.

(Permission of G. O. Shields, publisher of Recreation.) 


\section{CHAPTER XV}

\section{HOMES AND DOMESTIC HABITS}

142. Importance of care of the young.- The nest-building and domestie habits of animals are adaptations, but adaptations of behavior or habit rather than of strueture, and are based on instinet, intelligenee, and reason. These instinets and habits are among the most important shown by animals, beeause on them depends largely the eontinuanee of the speeies. Of primary importanee in the perpetuation of the speeies is the possession by animals of adaptations of strueture and behavior, whieh help the individual live long enough to attain full development and to leave offspring. But in the ease of many animals a sueeessful start in life on the part of the offspring depends on the existenee in the parents of eertain domestie habits eoneerned with the eare and proteetion of their young. The young of many animals depend absolutely, for a part of their lifetime, on this parental eare. In these eases it is quite as neeessary for the eontinued existenee of the speeies that the habits that afford this eare be sueeessful as that the parent shonld eome sneeessfully to mature development and to the prodnetion of offspring.

143. Care of the young, and communal life.-The nestbuilding or home-making habits and the eontinued personal eare of the young for a part of their lifetime are most highly developed and widespread among the birds, manmals, and inseets; and it is both among the inseets and the higher vertebrates that we find most developed those soeial and eommunal habits disenssed in Chapter IX. 'The prineipal aetivities of an animal eommunity have to do 
with the protection and sustenance of the young, and the care of the young is undoubtedly a chief factor in the development of eommunal life.

144. The invertebrates (except spiders and insects).Among the lower invertebrates parental aid to the young is confined almost exelusively to exhibitions of pure instinct. And this is true of many of the higher animals also. Eggs are deposited in sheltered places, and in such plaees and under such eireumstances that the young on hatehing will find themselves elose to a supply of their natural food. The depositing of eggs in water by parents with terrestrial habits whose young arc aquatic, is an example. The toad, which lives on land, feeding on insects, has young which live in water and feed on minute aquatic plants (alga). The dragon fly, that hawks over the pond or brook with glistening wings, has young that erawl in the slime and mud at the bottom of the pool. With most animals, after laying eggs, the parents show no further solicitude toward their offspring. The eggs are left to the vieissitudes of fortune, and the parents know nothing of their fate. In many eases the parent dies before the young are hatehed. The mammals and birds are the only two great groups excepted, although there are numerous specifie exeeptions seattered among the lower invertebrates, fishes, batrachians, and higher invertebrates, notably the inseets.

There are no instanees of eare of the young after hatehing among the sponges, polyps, worms, ol star-fishes and sea-urehins, and but few among the crustaceans and mollusks. But there are in some of these groups a few eases of nest or home building in a erude and simple way. Certain sea-urchins (Fig. 156) and worms and mollusks bore into stones, and remain in the shelter afforded by the eavity. A shell-fish (Lima hiams) cements together bits of eoralline, shells, and sand to form a crude nest or hidingplace. 'The cray-fish digs a cylindrical burrow in the ground in which it ean hide. 
145. Spiders.-Most spiders spin silkcn cocoons or saes in whieh to deposit their eggs. Somc spiders earry this egg-filled eocoon about with them for the sake of protceting the eggs. Aftcr hatehing, the spiderlings remain in the coeoon a short time, feeding on each other! 'Thus only the

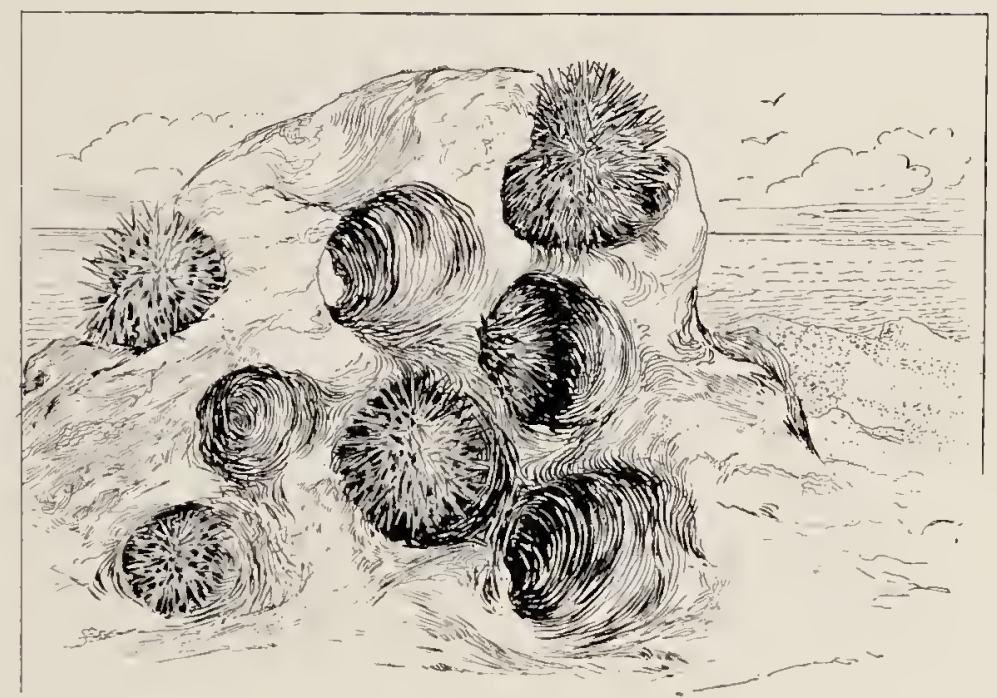

Fig. 156.-Sea-urchins living in holes bored into rocks of the scashore below hightide line.

strongest survive and issue from the eocoon to earn their living in the outcr world. With certain species of spiders the young after hatehing lcave the coeoon and gather on the baek of the mother and arc carricd about by her for some time. In conneetion with their webs or snares many spiders have silken tunnels or tubes in whieh to lie hidden, a sort of shcltering nest. Those spiders that live on the ground make for themsclves cylindrical burrows or holes in the ground, usually lined with silk, in which they hidc when not hunting for food. Espccially intcresting among the many kinds of these spider nests are the burrows of the various trap-door spiders. These spiders are common in California and some other far Mestern States. The bur- 
row (Fig. 15\%) or eylindrical hole is elosed above by a silken, thick, hinged lid or door, a little larger in diameter than the hole and neatly beveled on the edge, so as to fit tightly into and perfeetly eover the hole when elosed. The upper surface of the door is covered with soil, bits of leaves, and wood, so as to resemble very exactly the ground surface about it. We have found these trap-door nests in California in moss-eovered ground, and here the lids of the nests were always eovered with green, growing moss.

An English naturalist who studied the habits of these trap-door spiders found that if he remored the soil and bits of bark and twigs, or the moss, from the upper surface of the lid the spider always re-eovered it. It is, of course, plain that by means of this eovering the nest is perfectly conecaled, the surface of the elosed door not being different from the surroundiug ground surface. This naturalist finally removed the moss not only from the surface of a trap-door, but also from all the ground in a eirele of a few feet about the nest. The next day he found that the spider had brought moss from outside the cleared spaee aud covered the trap-door with it, thus making it rery eonspicuous in the eleared ground spaee. The spider's instinet was not eapable of that quick modifieation to allow it to do what a roasoning animal would have done-namely, eov(red the trap-(foor only with soil to make it resemble the eleared ground about it.

Another interestiug nest-making spider is the turretsprider, that builds up a little tower (Fig. 158) of sticks and soil aud moss above its burow. 'The sticks of which this burow are built are an inch or two in length, and are arranged in such manuer as make the turet five-sided. The stieks are fastened together with silk, and the turret is made two or three inehes high. This turret-building spider is one of those that earry about their egg-eoeoon with them. A female of this spider in eaptivity was observed to pay much attention to earing for this eoeoon. 


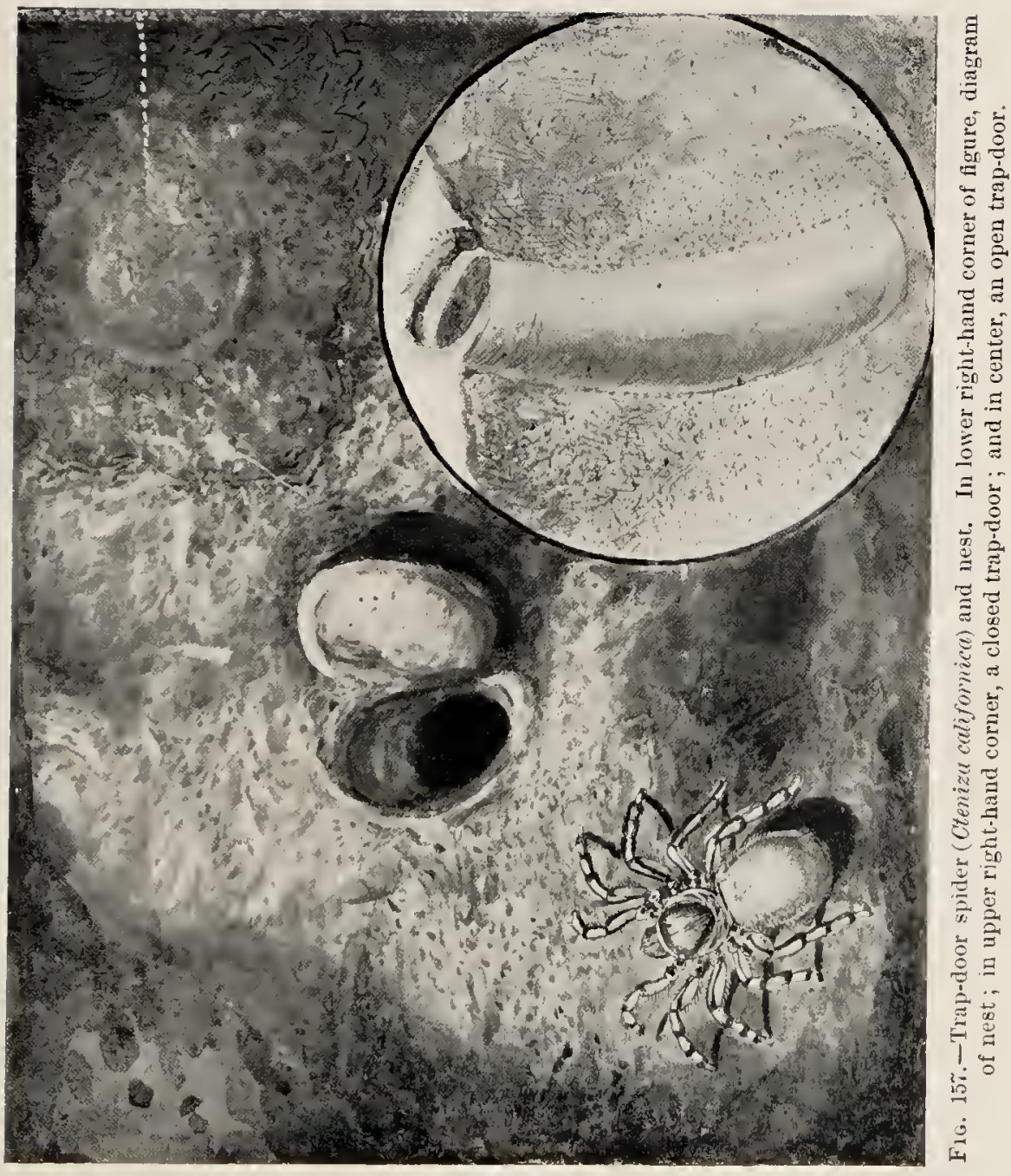


"If the weather was eold or damp, she retired to her tunnel; but if the jar in whieh she lived was set where the sun eould shine upon it, she soon re-

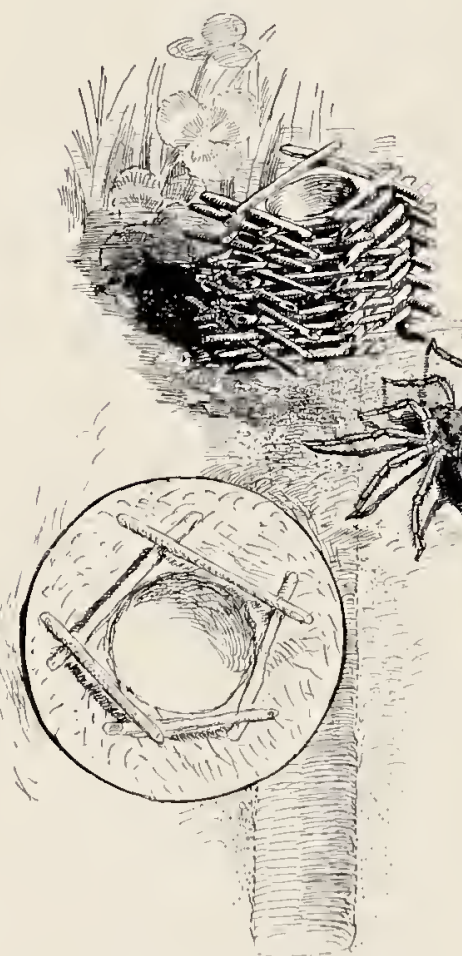

Hig. 158.-Nest of the turretspialer. appeared and allowed the eoeoon to bask in the sunlight. If the jar was plaeed near a stove that had a fire in it, the eoeoon was put on the side next the sonrce of warmth; if the jar was turned aromnd, she lost no time in moring the eocoon to the warmer side. Two months after the eggs were laid the yomg spiders made their a pearanee and immediately perehed upon their mother, many on her baek, some on her head, and even on her legs. She earried them about with her and fed them, and mitil they were older they never leit theil mother for a moment."

1+6. Insects. - So much space his alleady been deroted to an aeeount of the claborate nest-making and domestie habits of the bees, ants, and termites (see Chapter IX), that we need in this place merely refer to that account. It is among these social inseets that the most interesting and highly specialized habits eonnected with the care of the youmg and the building of homes are fommd.

Many insects make for themselves simple burrows or nests in the ground or in wood. The young or larve of eertain moths burrow about in the soft inside tissne of leaves, and the whole life of the moth except its short adult stage is passed inside the leaf. These larva are ealled leaf- 
miners. The larvæ of some moths and of many hymenopterous inseets live in galls on live plants. These galls are simply abnormal growths of plant tissue, and are caused by the irritating effect on the tissue of the larvæ which hateh from eggs that have been thrust into the soft plant substance by the female inseets. In the familiar galls on the golden-rod live the larve of a small moth, and in the various kinds of oak galls live the young of the numerous speeies of Cynipidce, the hymenopterous gall inseets. The tiny larvæ of some of the midges live in small galls on various plants. To this last group of gall-making inseets belongs the dreaded Hessian fly, the most destructive insect pest of wheat.

Among the bees and wasps only a few species, comparatively, are eommunal or live in communities. But nearly all the wasps and bees, whether soeial or solitary in habit, build nests for their young and provide the young with food, either by storing it in the nest or by hunting for it and bringing it to the nest as long as the young are in the larval condition. The "mud-daubers" or thread-waisted wasps make nests of mud attached to the lower surface of flat stones, to the eeiling of buildings, or in other out-ofthe-way and safe plaees. These nests usually have the form of several tubes an ineh or so long plaeed side by side. In each of the tubes or eells an egg is laid, and with it a spider which has been stung so as to be paralyzed but not killed. When the young wasp hatehes from the ogg as a grub or larva, it feeds on the unfortumate spider. Others of the solitary wasps make nests in the ground or in wood, and all of them provision their nests with some partienlar kind of inseet or spider. Some use only eaterpillars, some plant-lice, and some grasshoppers. Similarly the solitary bees make nests in the ground as do the mining-bees, or in wood as do the earpenter-bees, or by entting and fastening together loaves, as do the leaf-cutting bees. The bees provision their nests, not with paralyzed 
inseets, but with masses of pollen or pollen mixed with neetar.

14\%. The vertebrates. - It is among the vertebrates, espeeially in the ligher groups, the birds and mammals, that we find the eare of the young most perfeetly undertaken and most widespread.

Among the fishes, the lowest of the vertebrates, most speeies eontent themselves with the laying of many eggs in a situation best suited for their safe hatehing. But some speeies show interesting domestie habits. The female catfish swims about with her brood, mueh as a hen moves about with her ehiekens. Some of the larger oeean catfish of the tropies reeeive the eggs or the young within the mouth for safety in time of danger. Certain sunfishes eare for their young, keeping them together in still places in the brook. They also make some traees of a nest, whieh the male defends. The male silmon seoops out gravel to make a shallow nest, in which the female deposits her eggs. 'The male then covers the eggs. The males of the speeies of pipe-fish and sea-horses receire the eggs of the female into a groove or sae between the folds of skin on the lower part of the tail. Ilere they are kept until the little fishes are large enough to swim alout for themselves. The brave little sticklebacks build tiny nests about an inel and a half or two inehes in diameter, with a small opening at the top. The egrgs are laid in this nest, and the young fish remain in it some time after hatching. The male parent jealously guards the nest, and fights bravely with would-be intruders.

The batraelians and reptiles rarely show any care for their young. 'The eggs of most batraehians are laid in the water and left by the female. The males of the Surinan toad receive the eggs in pits of the spongy skin of the baek, where they remain until the young hatel. The eggs of snakes are laid muder logs or buried in the sand, and no further attention is given them by the parents.

Among the birds, on the other hand, nest-building and 
care of the young are the rule, and a high degree of development in these habits is reached. All of us are familiar with many different kinds of nests, from the few twigs loosely put together by the mourning-dove to the firm, closely knit, wool or feather lined nest of the hummingbird (Fig. 159), and the basket-like hanging nest of the

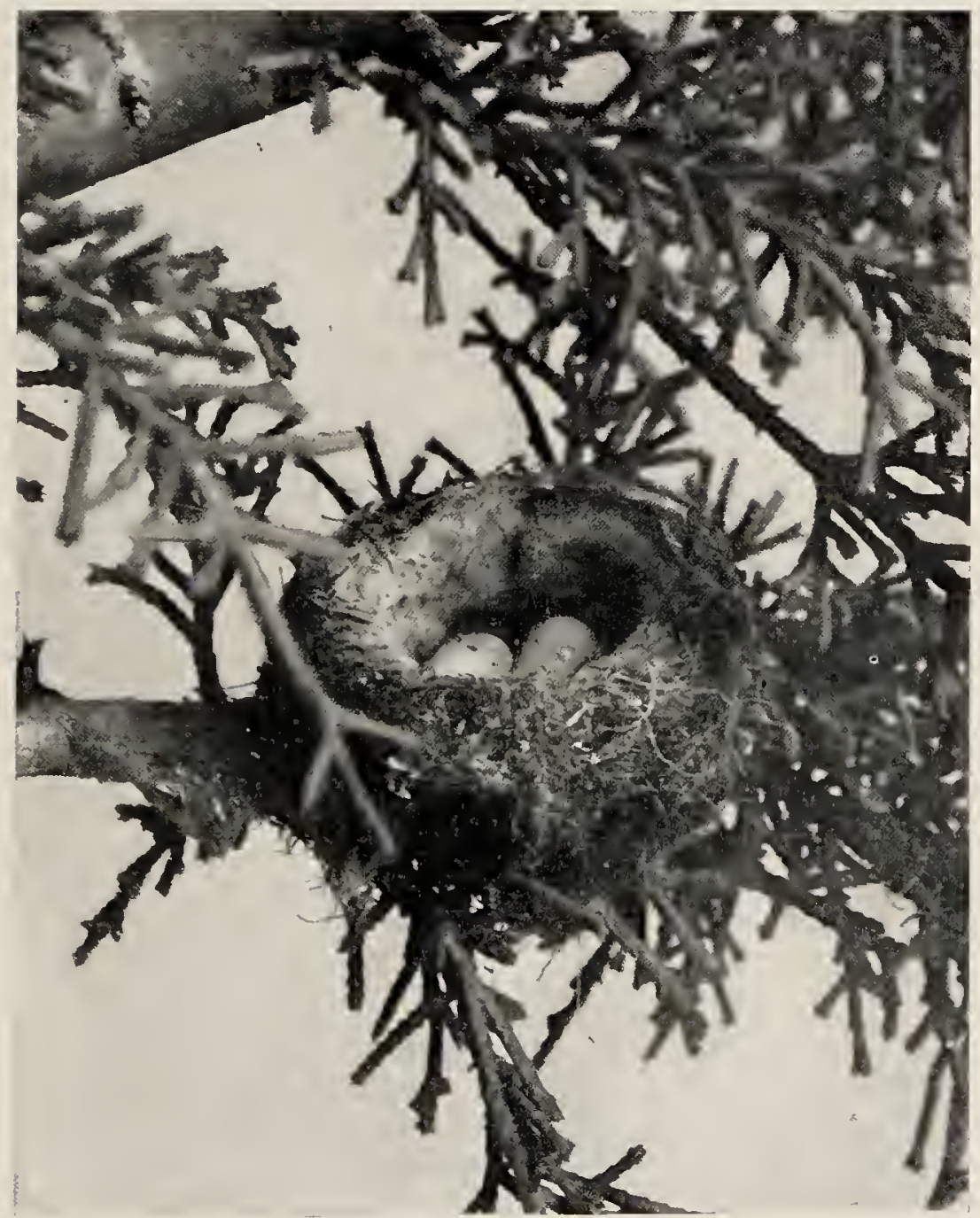

Fit. 159.-Nest and eggs of the Rufus humming-bird (Thochillis yufus). Photograph by J. O. SNYDER, Srantorl University, California. 
oriole (Fig. 161). Not all birds make nests. On the rocky islets of the northern oceans, where thousands of puffins and auks and other maritime birds gather to breerl, the eggs are laid on the bare rock. At the other extreme is the tailor bird of India, which sews together leaves by means of fibrous strips plucked from a growing plant to

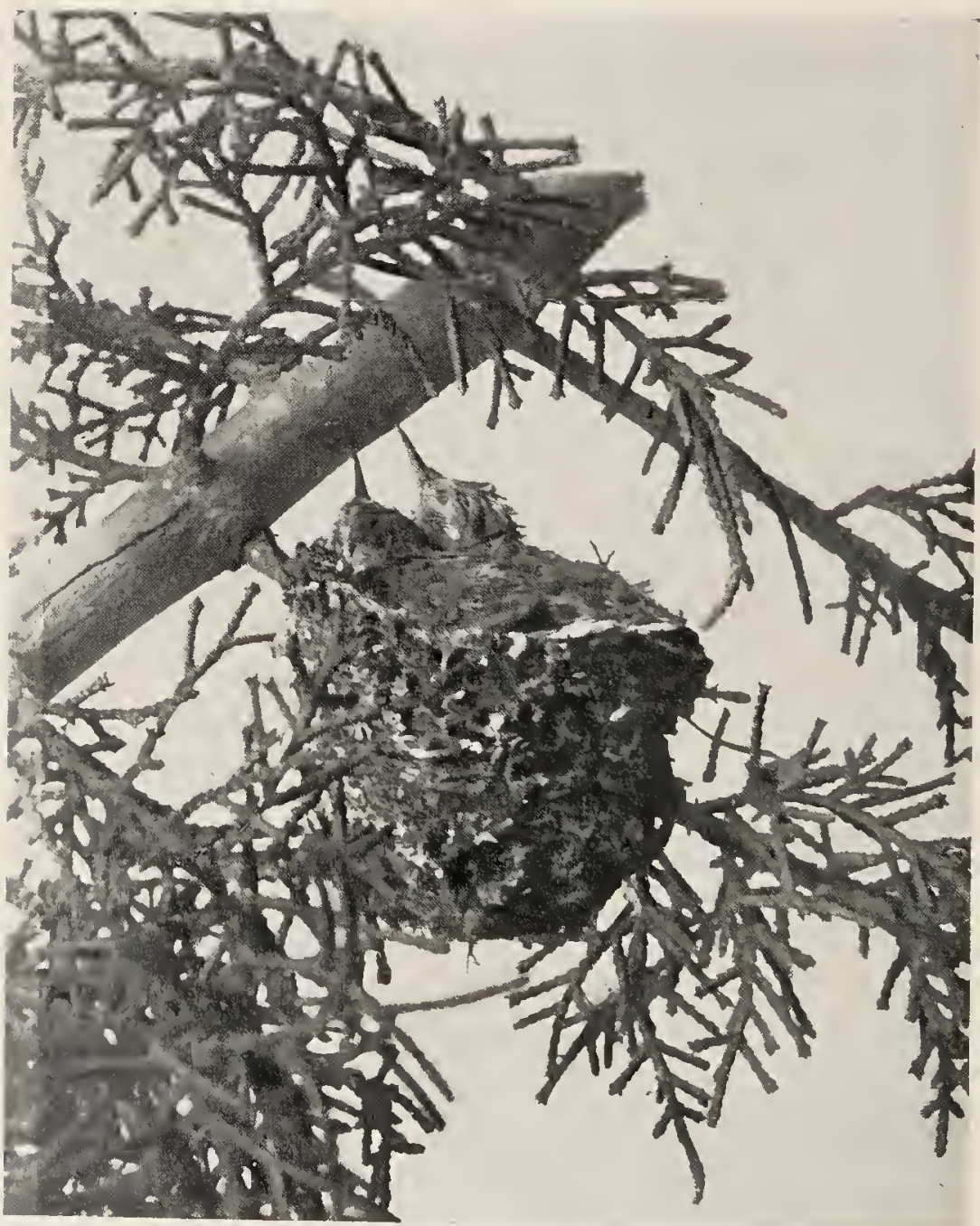

Fia. 160.-Nest and youmer of the Rufus hnmming-bird ('Trochilus rufus). Photograph by J. O. SNYDER, Stanford University, California. 


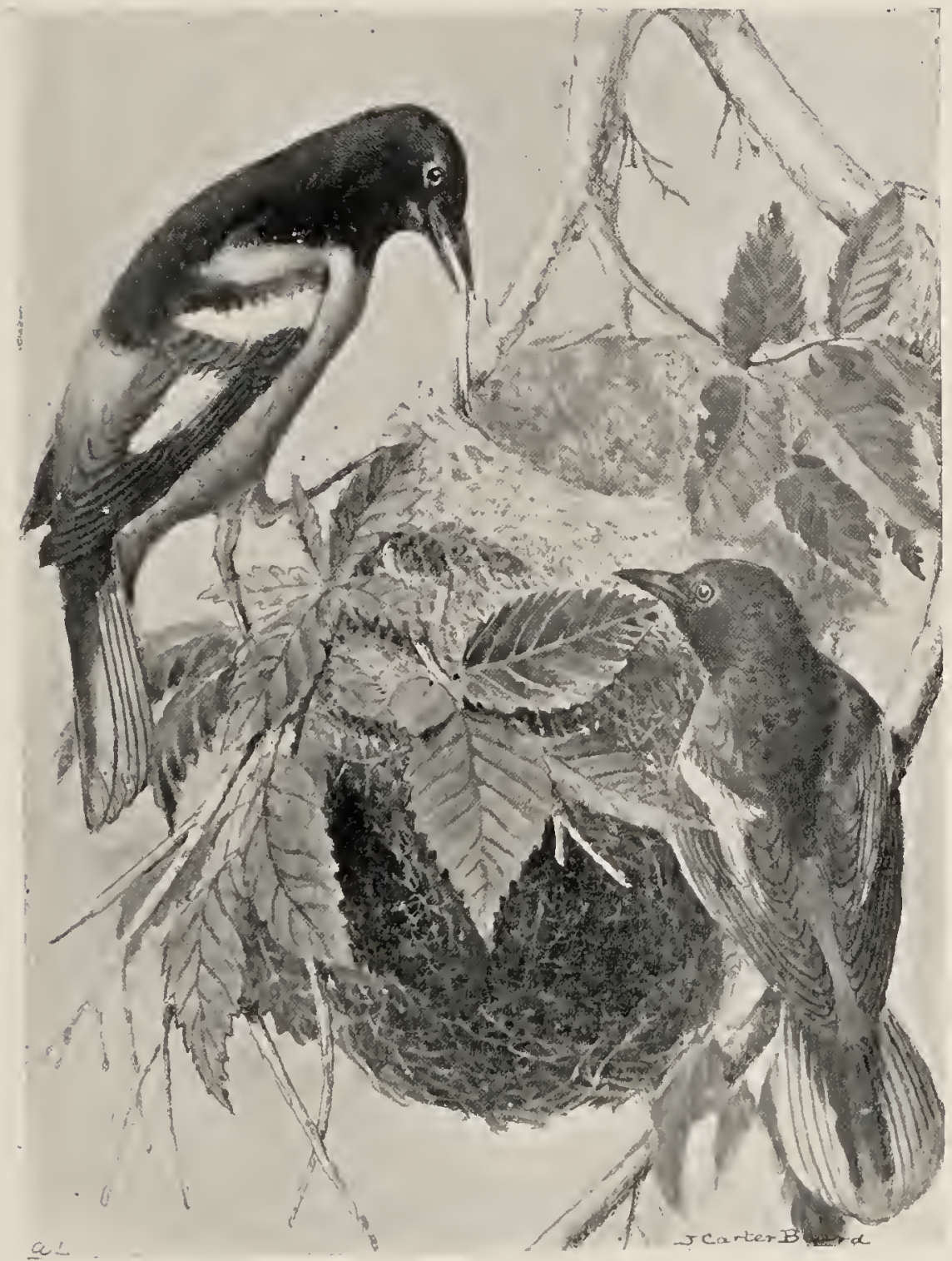

Fig. 161.-Baltimore orioles and nest; the male in upper left-hand corner of figure.

form a long, bagrlike nest (Fig. 162). In the degree of care given the nestlings there is also much difference. The robin brings food to the helpless young for many days, and 
finally teaches it to fly and to hunt for food for itself. Young chickens are not so helpless as the nestling robins, but are able to run about, and care of the hen mother to

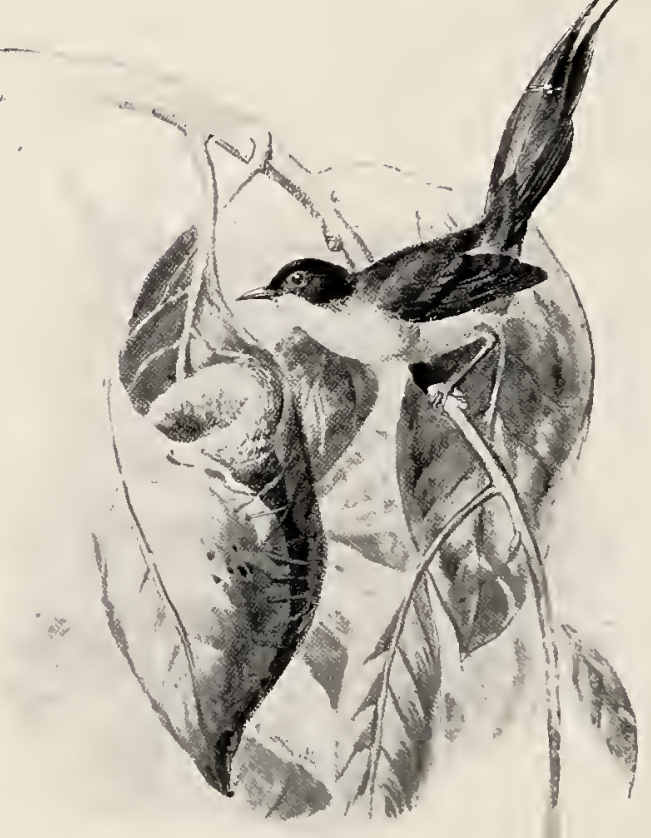

Fut 16:-Tailor-bird (Ornithotomus sutorius) and nest. under the guiding pick up food for themselves.

Among the mammals the young are always given some degree of care. Excepting in the ease of the duek-bills, the lowest of the mammals, the young are born alive-that is, are not hatched from eggs laid outside the body - and are nourished after birth for a shorter or longer time with milk drawn from the body of the mother. Before birth the young undergoes a longer or shorter period of development and growth in the body of the mother, being nomished by the blood of the mother. The nests or homes of mammals present rarying degrees of daboratencss, from a simple cave-like hole in the rocks or ground to the elaborately construeted villages of the beavers with their dams and conical several-storied louses (Hig. 163). The wood-rat piles together sticks and twigs in what seems, from the oufside, a most haphazard fashion, but which results in the construction of a convenient and ingenious nest. The moles and pocket-gophers (Fig. 165) build underground nests composed of chambers and gal- 


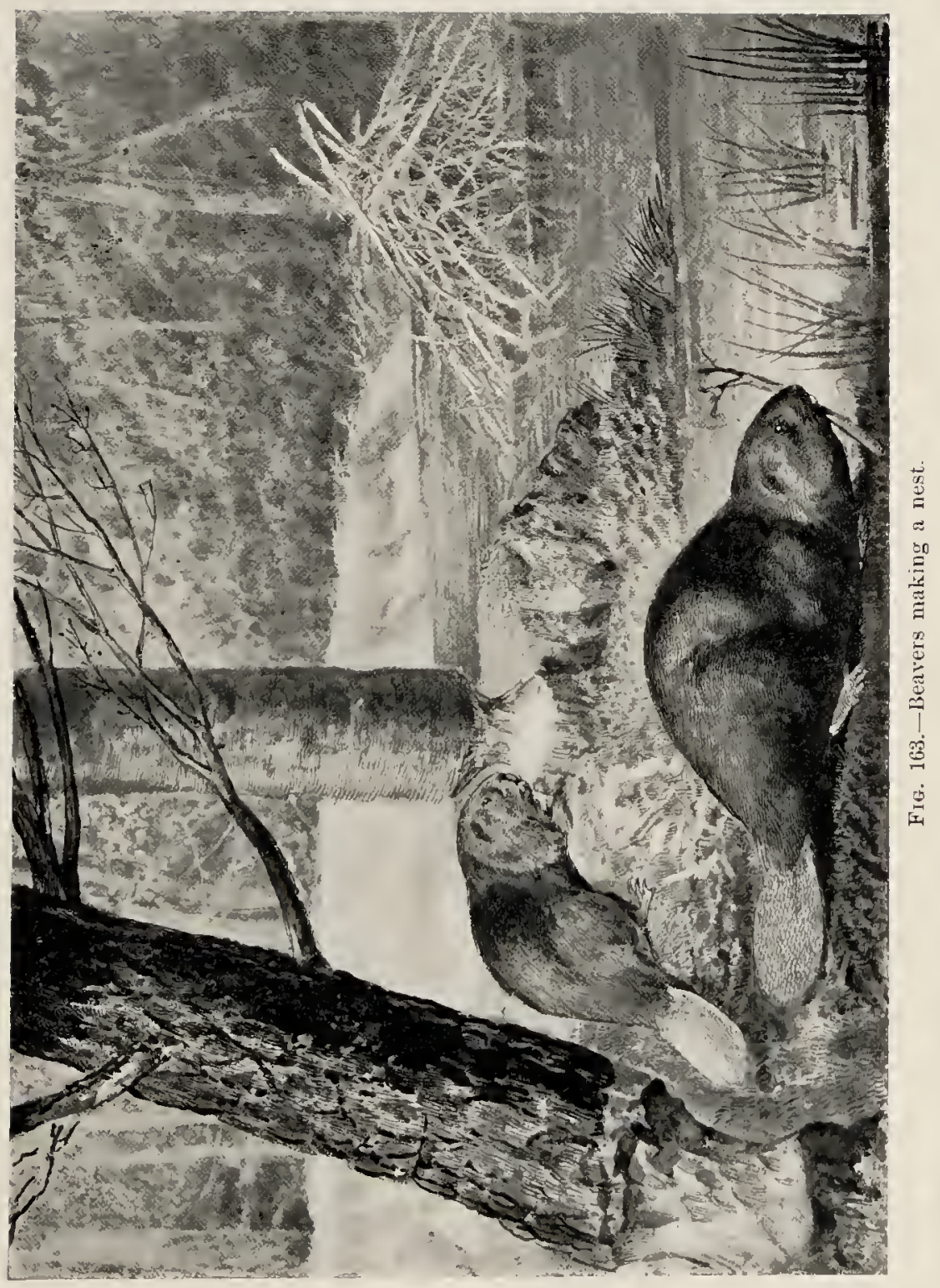




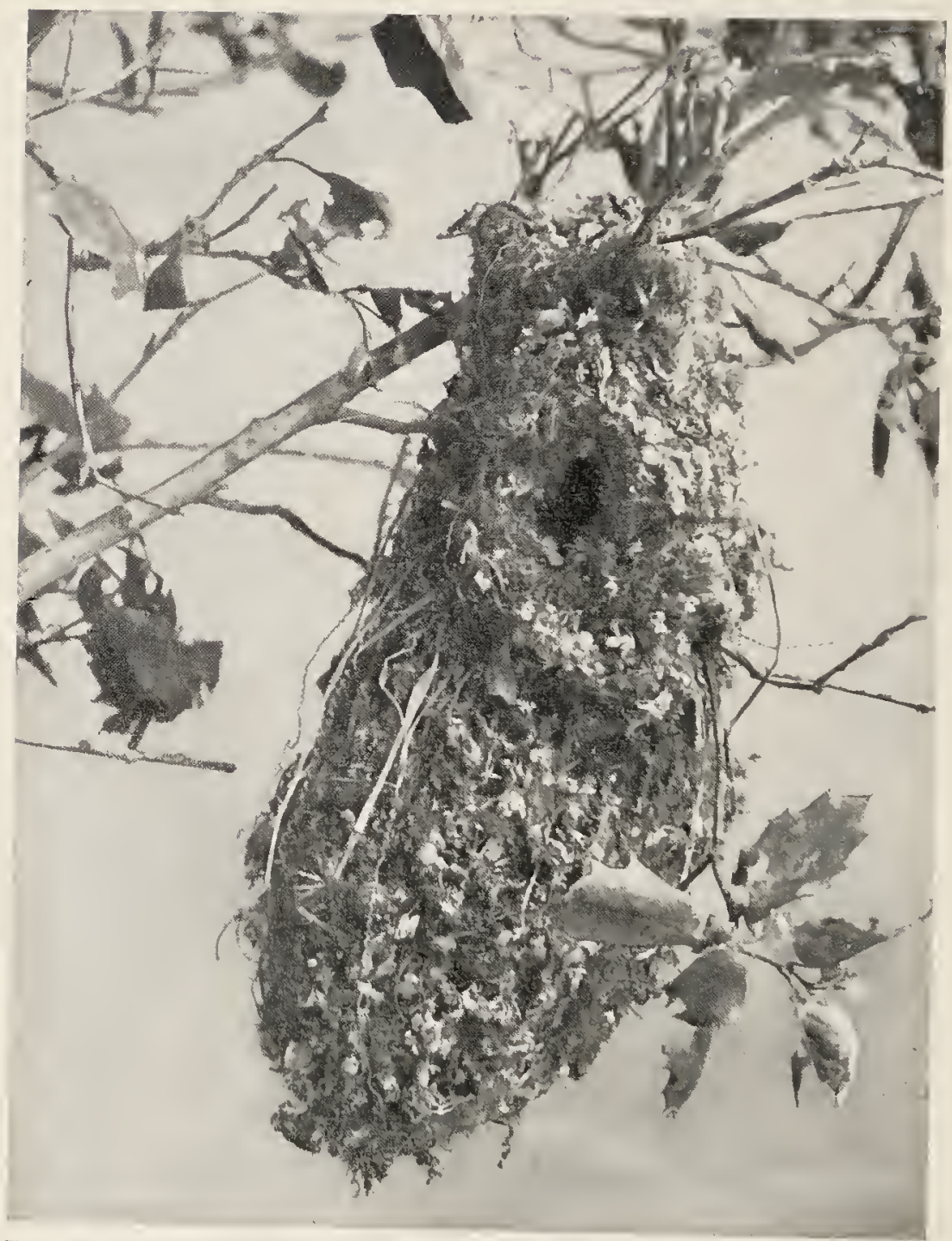

Fre. 161.-Nest of the Californian bush-tit (Psaltrimams minimus). Photograph by (i. O. SNYuEn, stmatord Unirersity, California.

leries. The pritrie-dogs make burrows in groups, forming large villages.

'ille devotion to their young displayed by birds and manmals is familial to us. The parents will often risk or 
suffer the loss of their own lives in protecting their off spring from enemies. Many mother birds have the instinet to flutter about a diseovered nest erying and apparently broken-winged, thus learling the predatory fox or weasel to

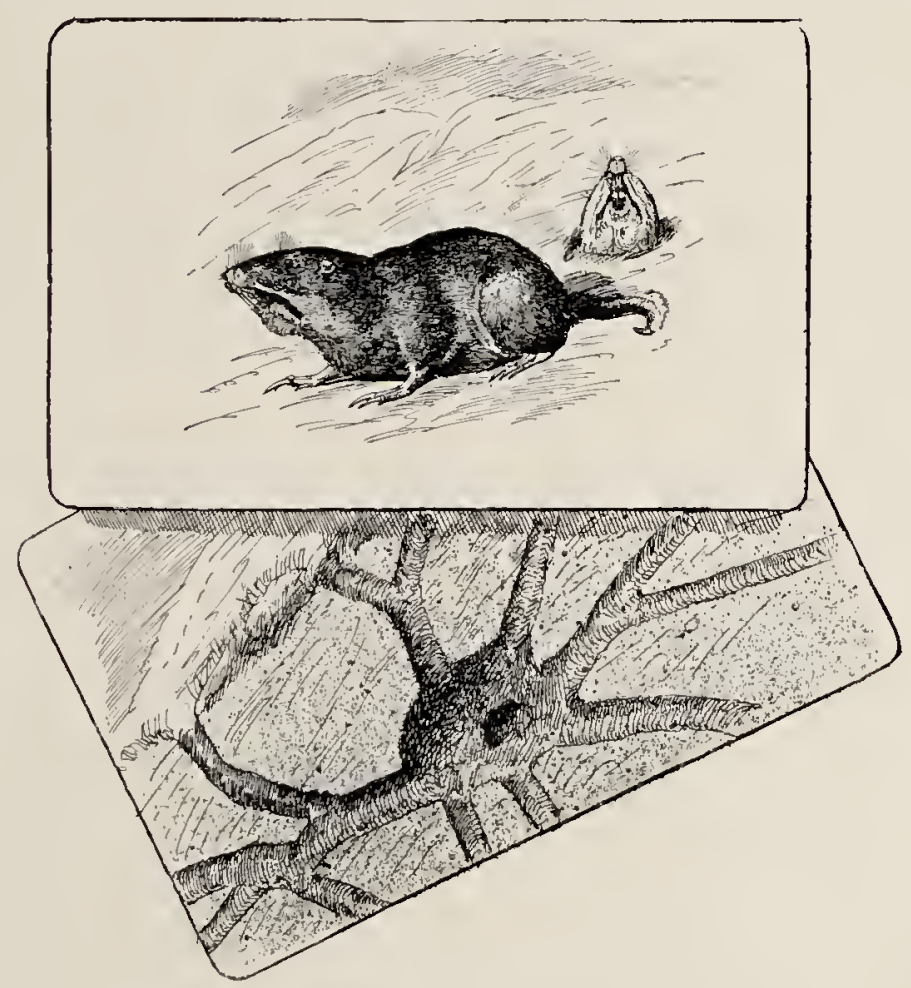

Fili. 165,-Nest and run-way of the pocket-gopher.

fix his attention on the mother and to leave the nest unharmed. This development of parental care and proteetion of the young reaches its highest degree in the case of the human speeies. The existenee of the family, which is the unit of human soeiety, rests on this high development of care for the young. 


\section{CHAPTER XVI}

\section{GECIGRAPHICAL DISTRIBUTION OF ANIMALS}

148. Geographical distribution.-Under the head of distribution we eonsider the facts of the diffusion of organisms over the surface of the earth, and the laws by which this diffusion is governed.

The geographieal distribution of animals is often known as zoögeography. In physical geography we may prepare maps of the earth which shall bring into prominenee the physical features of its surfaee. Sueh maps would show here a sea, here a platean, here a range of mountains, there a desert, a prairie, a peninsula, or an island. In political geography the maps show the physieal features of the earth, as related to the states or powers whieh elaim the allegianee of the people. In zoögeography the realms of the earth are eonsidered in relation to the types or speeies of animals which inhabit them. Thus a series of maps of the United States eonld be drawn whieh wonld show the gradual disappearanee of the buffalo before the attacks of man. Another might be drawn whieh wonld show the present or past distribution of the polar bear, black bear, and grizzly. Still another miglit show the original range of the wild hares or rabbits of the United States, the white rabbit of the Northeast, the eotton-tail of the Last and South, the jaek-rabbit of the plains, the snowshoe rabbit of the Columbia River, the tall jack-rabbit of Califormia, the black rabbits of the islands of Lower Califonia, and the marsh-hare of the South and the water-hare of the canebrakes, and that of all their relatives. Snel a 


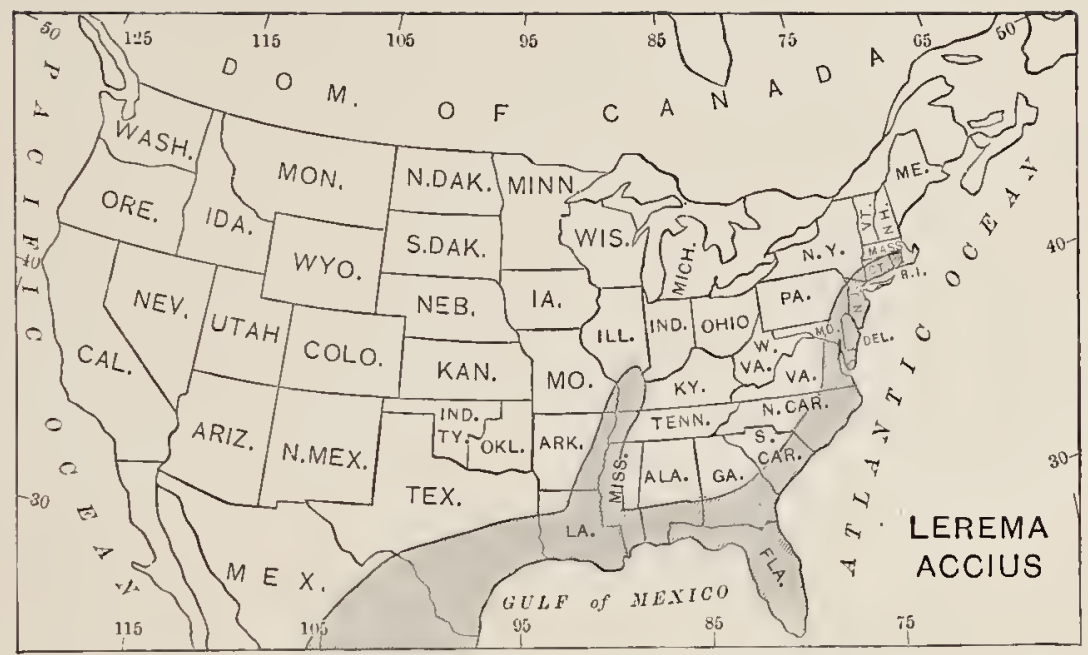

Fic. 166.-Map showing the distribution of the clouded Skipper butterfly (Lerema accizs) in the United states. The butterfly is found in that part of the conntry shaded in the map, at warm and moist region.-After Scudoer.

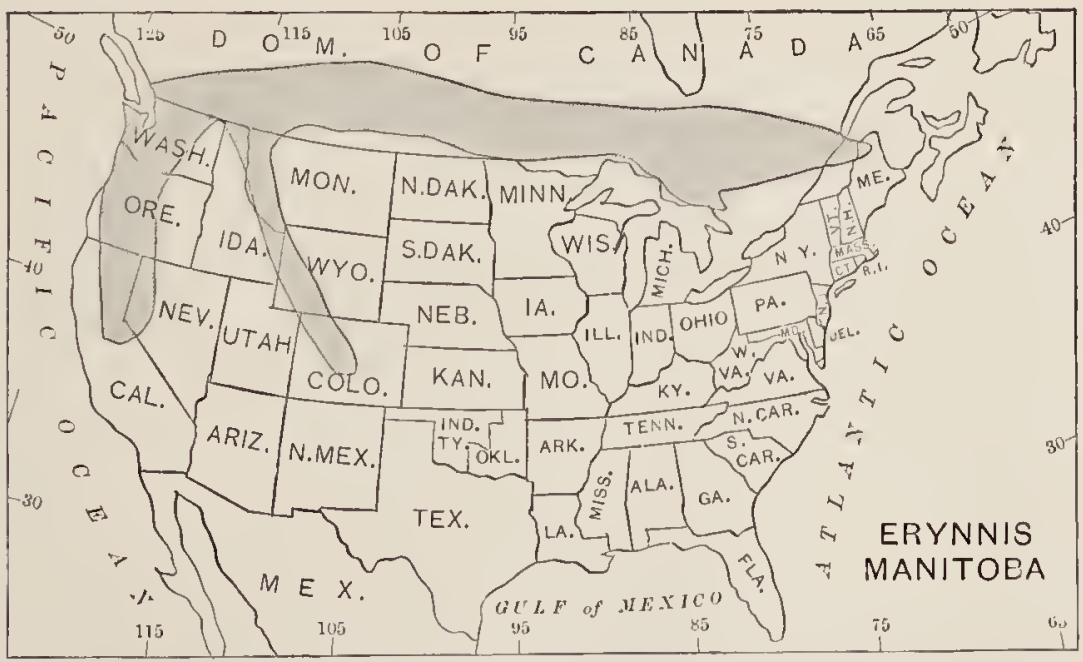

FIr. 16\%.-Wap shnwing the distribution of the Canadian Skipper butterfly (Erynnis manitoba) in the Uniter States. Tle butterfly is found in that part of the country shaded in the map. This butterfy is suburctic and subalpine in distribution, being fornd only far north or on hirh monntains, the two southern projecting parts of its range being in the locky Mountains and in the sierra Nevada Mountains. - After ScUDDER. 
map is very instructive, and it at onee raises a series of questions as to the reasons for each of the facts in geographical distribution, for it is the dnty of science to suppose that none of these faets is arbitrary or meaningless. Each fact has some good eanse behind it.

149. Laws of distribution.-The laws gorerning the distribution of animals are reducible to three very simple propositions. Every speeies of animal is found in every part of the earth having conditions suitable for its maintenanee, unless-

(a) Its individnals have been mable to reach this region, through barriers of some sort; or-

(b) Having reached it, the species is mable to maintain itself, through lack of capacity for adaptation, throngh severity of competition with other forms, or through destruetive conditions of environment; or-

(c) Having entered and maintained itself, it has become so altered in the process of adaptation as to become a speeies distinct from the original type.

150. Species debarred by barriers. Is examples of the first elass we may take the absence of kingbirds or meadowlarks or eoyotes in Enrope, the absenee of the lion and tiger in Sonth Ameriea, the absence of the eivet-eat in New York, and that of the bobolink or the Chinese flying-fox in California. In eaeh of these cases there is no evident reason why the speries in question shonld not maintain itself if onee introduced. The fact that it does not exist is, in gencral, an evilence that it has never passed the barriers whieh separate the region in question fron its original home.

Local illustrations of the same kind may be fomnd in most mountainous regions. In the Yosemite Valley in California, for example, the trout aseend the Merced River to the base of a vertical fall. They ean not rise above this, and so the streams and lakes above this fall are destitute of fish. 
151. Species debarred by inability to maintain their ground. - Examples of the second class are secn in animals which man has introduced from one country to another. The nightingale, the starling, and the skylark of Europe have been repeatedly set free in the United States. But none of these colonies has long endured, perhaps from lack of adaptation to the climate, more likely from severity of competition with other birds. In other cases the introduced spccies has been better fitted for the conditions of life than the native forms themselves, and so has graduallv crowded ont the latter. Both these cases are illustrated among the rats. The black rat, first introduced into America from Europe about 1544, helped erowd out the native rats, while the brown rat, brought in still later, about 1\%\%, in turn practically exterminated the black lat, its fitness for the conditions of life here bcing still gruater than that of the other European species.

Certain animals have followed man from lind to land, having been introduced by him against his will and to the detriment of his domestic amimals or crops. To many of these the term vermin has been applied. Among the vermin or "animal weeds" arc certain of the rodents (rats, mice, rabbits, etc.), the mongoose of India, the English sparrow, and many kinds of noxious insects. Of all the vermin of this class few have caused such widespread destruction of property as the common European rabbit introduced into Australia. 'The annual loss through its presence is estimated at $\$ 3,500,000$.

It often happens that man himself so changes the environment of a species that it can no longer maintain itself. Checking the increase of a species, cither by actually killing off its members or by adverse change in its surroundings, is to begin the process of its destruction. Circumstances become unfarorable to the growth or reproduction of an animal. Its numbers arc rednced, fewer are born each year, and fower reach maturity, it grows rare, 
is gone, and the final step of extinction may often pass nnnoticed.

But a few years ago the air in the Ohio Talley was dark in the season of migration with the hordes of passenger pigeons. The advance of a tree-destroying, pigeon-shooting civilization has gone steadily on, and now the bird which once crowded our Western forests is in the same region an ornithological curiosity. The extinction of the American bison or "buffalo," and the growing rarity of the grizzly bear, the wolf, and of large camivora generally, furnishes cases in point. When Bering and Steller landed on the Commander Islands in $1 \% 41$, the sea-cow, a large herbirorous creature of the shores, was abundant there. In about fifty years the species, being used for food by fishelmen, entirely disappeared. In most cases, however, a species that crosses its limiting barriers, but is unable to maintain itself, leaves no record of the ocemrence. We know, as a matter of fact, that stray individuals are very often found outside the usual limit of a species. A tropical bird nay be found in New Jersey, a tropical fish on Cape Cod, or a bird from Europe on the shores of Maine. Of course, hundreds of other cases of this sort must escape notice; but, for one reason or another, the great majority of these waifs are mable to gain a new foothold. For this reason, outside of the disturbances created by man, the geographical distribution of speeies changes but little from century to century; and yet, when we study the facts more closely, evidences of change appear everywhere.

15\%. Species altered by adaptation to new conditions.Of the third class or species altered in a new enviromment examples are numerous, but in most cases the causes involved can only be inferred from their effects. One class of illustrations may be taken from island faunæ. An island is set off from the mainland by barriers which species of land animals can very rarely cross. On an island a few waifs of wave and storm may maintain themselves, increasing in 


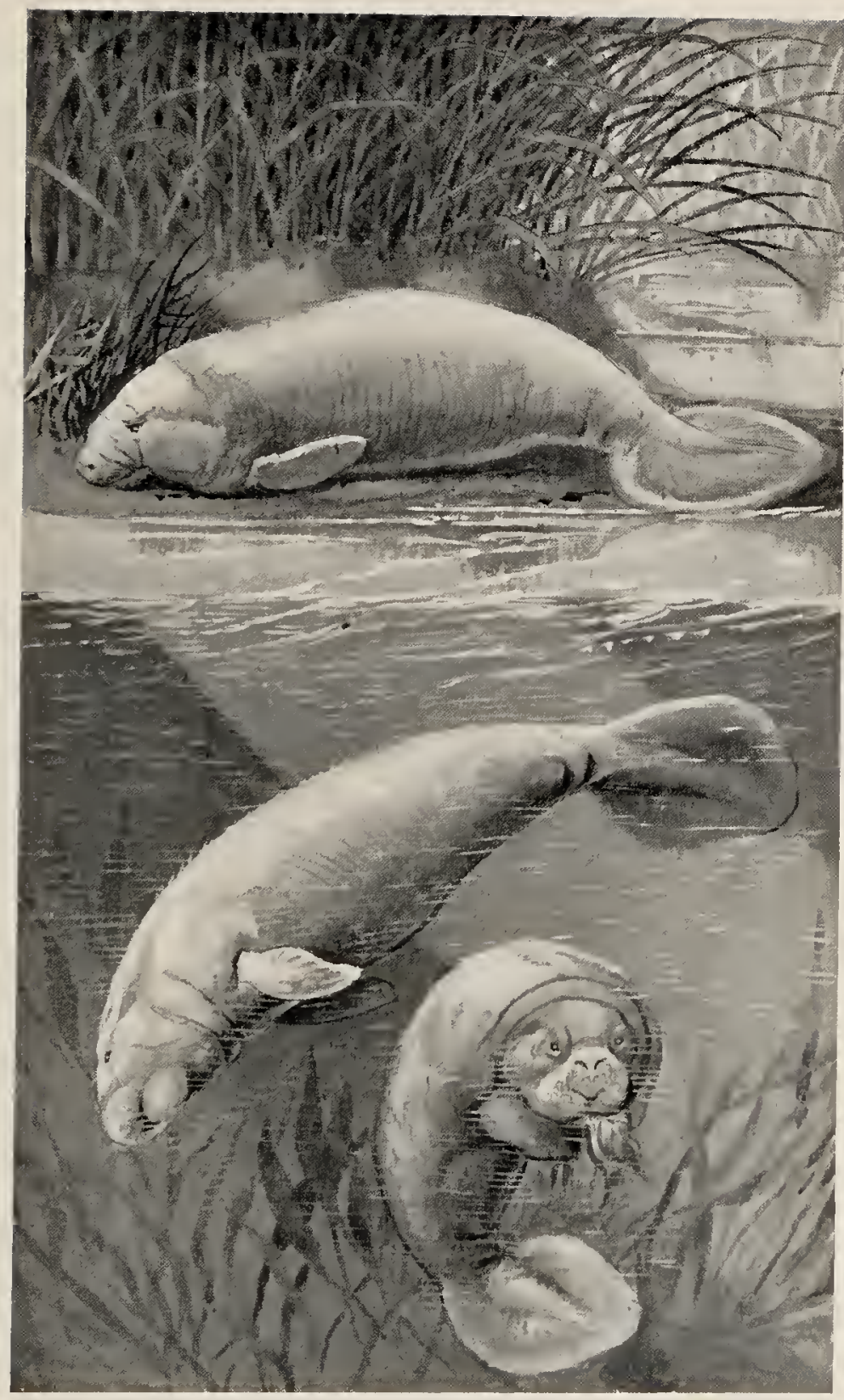

Fig. 168-The manater, or soa-cow (Trichechrelatirostris). A livine species of seacow related to the now extinct Steler's sea-cow. 


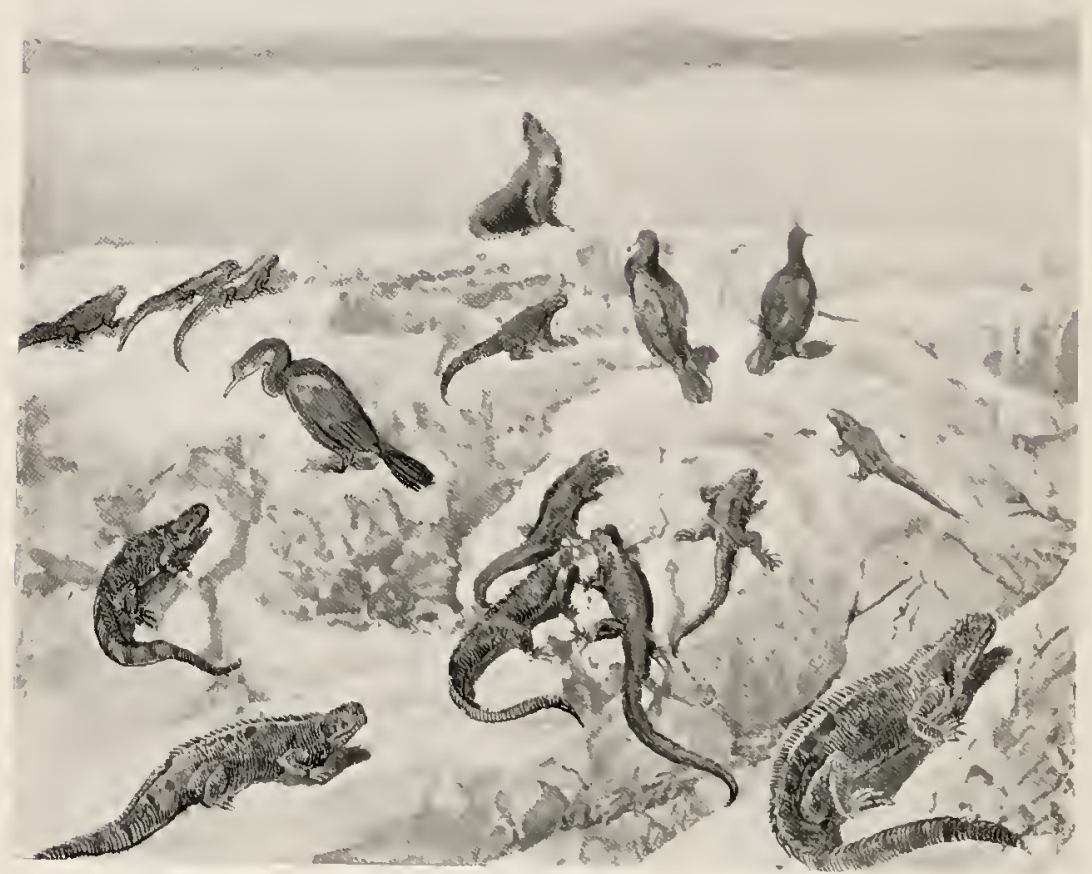

Fro. 169.-On the shorr of Narborongh Island, one of the Galaparos Islands. Pacific Ocean, showing peculiar suecies of sca-lions, lizards, and cormorals. Drawn from a photograpla male by Messre. SNomgrass and Hez,el:

numbers so as to oeeupy the territory; but in so doing only those will survive that can fit themselves to the new eonditions. 'Though this proeess a new species will be formed, like the parent species in general structure, but having gained new traits adjusted to the new environment. 
The Galapagos Islands are a cluster of volcanic rocks lying in the open sea about six hundred miles to the west of Ecuador. On these islands is a peculiar land fauna, derived from South American stock, but mostly different in species. Darwin noted there "twenty-six land birds; of these, twenty-one, or perhaps twenty-three, are ranked as distinct species. Tet the close affinity of most of these birds to American species is manifest in every character, in their habits, gestures, and tones of voice."

Among land animals similar migrations may oceur, giring rise, through the adaptation to new conditions, to new species. The separation of species of animals isolated in river basins or lakes often permits the acquisition of new characters, which is the formation of distinct species in similar fashion. On the west side of Mount Whitney, the highest nountain in the Sierra Nevada of California, there is a little strcam called Volcano Creck. In this brook is a distinet species or form of trout, locally called golden trout. It is unusually small, very brilliantly colored, its fins being bright golden, and its tiny scales scarcely overlap each other along its sides. This stream flows over a high waterfall (Igua Bonita) into the Kern River. The Kern River is full of trout, of a kind (Salmo gilberti) to which the golden trout is most closely allied. There can not be much doubt that the latter is descended from the former. With this assumption, it is easy to suppose that once the waterfall did not exist, or that through some agency we can not now ilentify certain fishes had been carried over it. Once above it, they ean not now return, nor can they mix with the common stock of the river. Those best adapted to the little stream have survived. The process of adaptation has gone on till at last a distinct species (or sub-species*) is formed. In recent times the

* In deseriptive works the nume species is applien to a form when the process of adaptation seems complete. When it is incomplete, or 


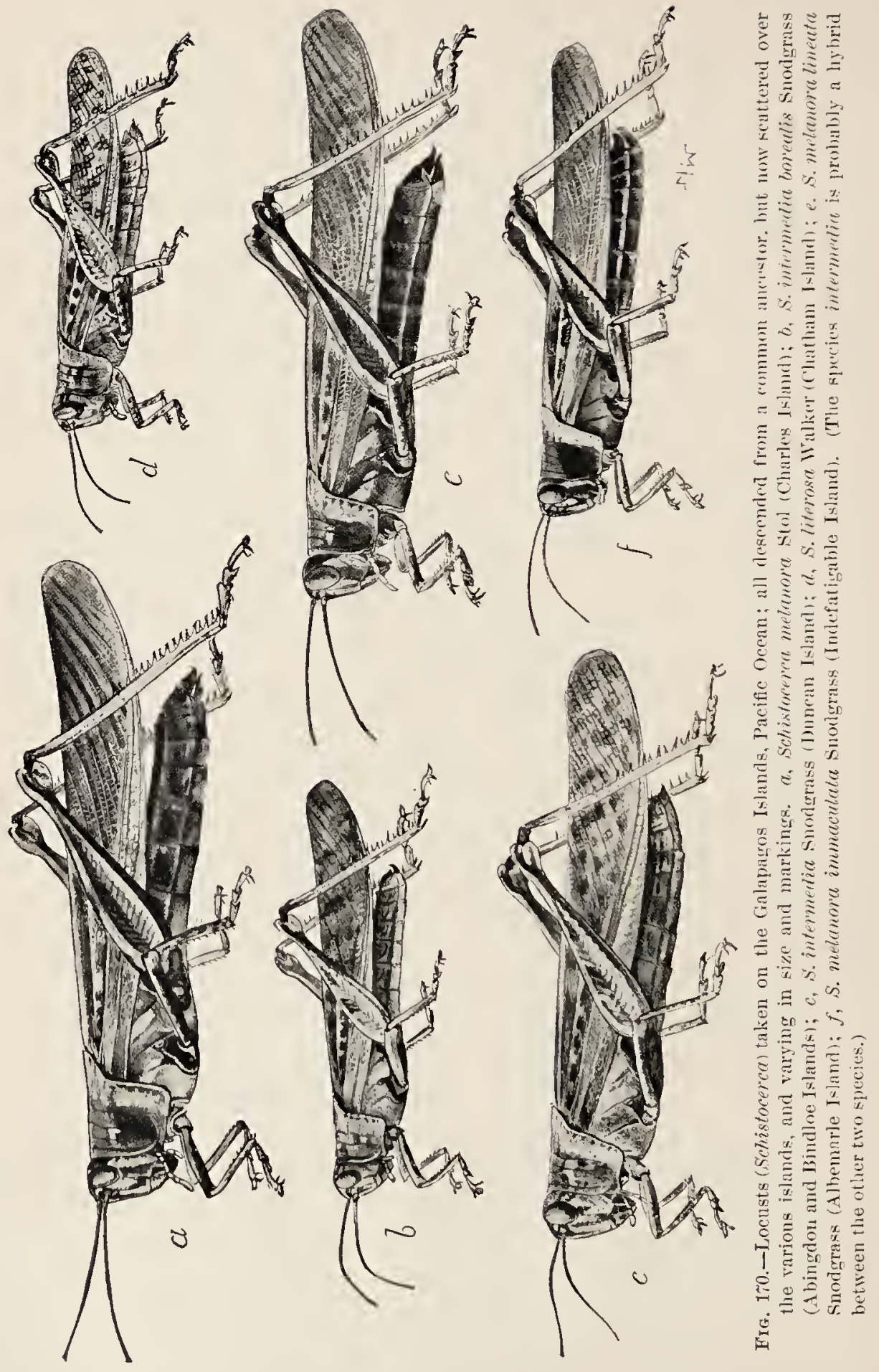




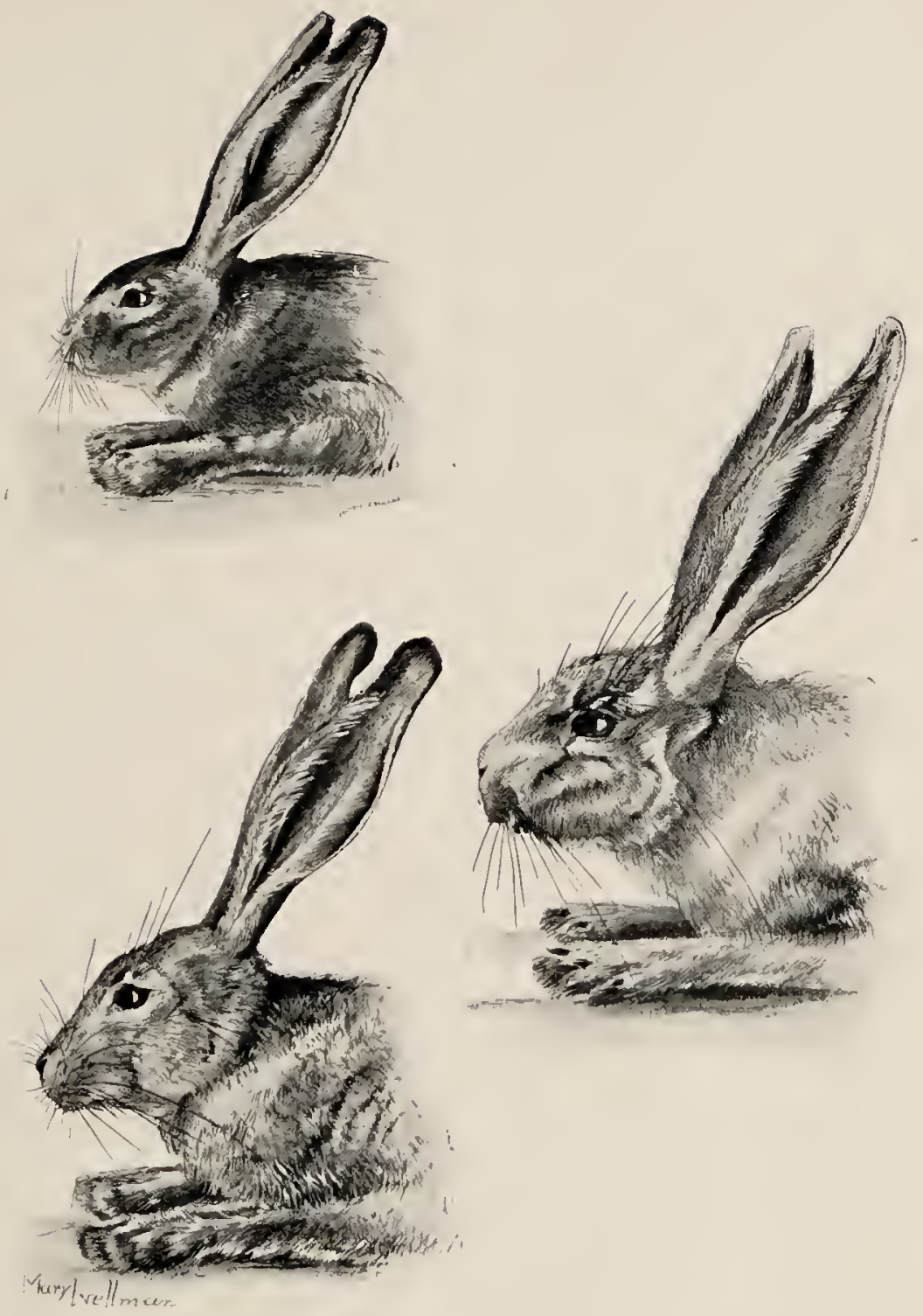

FiG. 171.-Three species of jack-rabbits, differing in si\%e, color, and markings, but believed to be derived from a common stock. The differences lave arisen throngly isolation and adaptation. The upper fignre shows the heat and fore leses of the black jack-rablit (Lepus insularis), of Espiritu Sinto Island, Gulf of California; the lower right-hand figure, the Arizona jack-rablit (Lemes alleni), specimen from Fort Lowell, Arizona ; and the lower left-hnd figure is the San Pedro Martir jack-rabbit (Lepus martirensis), from San Pedro Martir, Baja California. 
hand of man has carried the golden trout to other little mountain torrents, where it thrives as well as in the one where its peculiarities were first acquired.

Other cases of this nature are found among the blind fishes of the caves in different parts of the world (Fig. 1\%:).
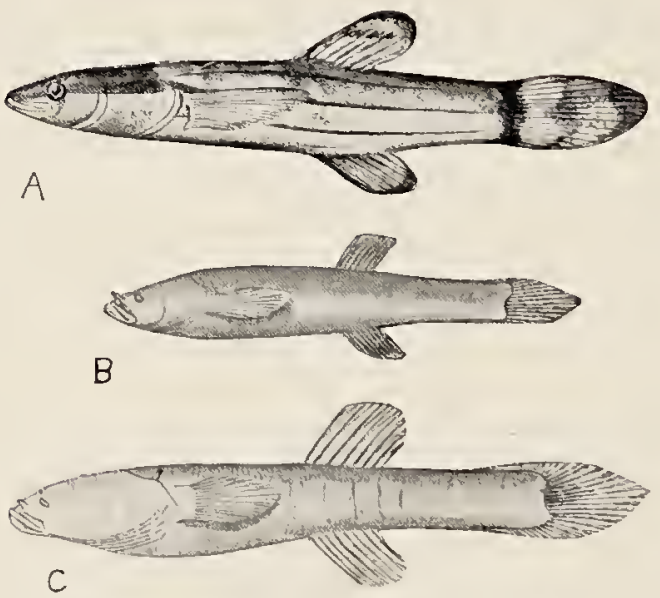

Fig. 172-Fishes showing stages in the loss of eres and color. A. Dismal swamp tish (Chologaster aretus), ancestor of the blind fish ; B. Angassiz's cave fish (Chologesuter agusizizi); C, cave blind fish (Typhlichthys subterraneus).

In general, cares are formed by the erosion or wearing of underground rivers. These streams are either clear and cold, and when they issme to the surface those fishes which like cold and shaded waters are likely to enter them. But to hare eyes in absolnte darkness, in which no nse can be made of them, is a disadrantage in the struggle for life. Hence the eyed species die or withdraw, while those in which the eye grows less from generation to generation, until its function is finally lost, are the ones which survive. By such lmoresses the blind fishes in the limestone cares of Kentuek Indiana, I'cnnessee, and Missouri have been formed.

rather when specimens showing intergratation of characters are known, the wort sub-species is used. The word variety has much the same meaning when nsed for a sublivision of a species, but it is a term defincl with less cxactness. Thus the common fox (Iulpes jennsylramicus) is a distinct species, being separate from the aretic fox or the gray fox or the fox of Europe. The crose fox (Tulpes pennsyluanicus decussatus) is culled a sub-speeies, as is the silver fox (Tulpes penusylv'anicus argentutus), beanse these intergrade perfectly with the common red fox. 
To processes of this kind, on a larger or smaller scale, the variety in the animal life of the globe is very largely due. Isolation and adaptation give the clew to the formation of a very large proportion of the "new species" in any group.

153. Effect of barriers.-It will be thus seen that geographieal distribution is prinarily dependent on barriers or checks to the morement of animals. The obstacles met in the spread of animals determine the limits of the speeies. Fach species broadens its range as far as it ean. It attempts unwittingly, through natural proeesses of inerease, to overome the obstacles of ocean or river, of mountain or plain, of woodland or prairie or desert, of cold or heat, of larek of food or abundance of enemies-whatever the barriers may be. Were it not for these barriers, each type or species would become eosmopolitan or universal. Man is pre-eminently a barrier-erossing animal. Hence he is found in all regions where human life is possible. The difierent races of men, however, find checks and barriers entirely similar in nature to those experieneed by the lower animals, and the race peeuliarities are wholly similar to characters acquired by new speries under adaptation to ehanged conditions. The degrce of hindrance offered by any barrier differs with the nature of the species trying to surmount it. That which constitutes an impassable obstacle to one form may be a great airl to another. The river whieh blorks the monkey or the cat is the highway of the fish or the turtle. The waterfall which limits the ascent of the fish is the chosen home of the ouzel. The mountain harrier which the bobolink or the prairie-dog does not cross may be the eenter of distribution of the ehief hare or the arctic bluebird.

154. Relation of species to habitat. - The habitat of a species of animal is the region in which it is found in a state of Nature. It is currently believed that the habitat of any ereature is the region for whieh it is best adapted. 
But the reverse of this is often truc. There are many eases in which a spccies introduecd in a new territory, through the voluntary or involuntary influence of man, has shown a marvelous adaptation and power of persistence. The rapid spread of rabbits and pigs as wild animals in Australia, of horses and cattle in South America, and of the English sparrow in North America, of bumble-bees and houseflies in New Zealand, are illustrations of this. Not one of thcse animals has maintained itself in the wild state in its native land as successfully as in these new countries to which it has been introdueed. The work of introduetion of useful animals illustrates the same fact. The shad, striped bass, and cat-fish from the Potomac River, introdueed into the Sacramento River and its tributaries by the United States Fish Commission, are examples in point. These valued food-fishes are nowhere more at home than in the new waters where no species of their types had ever existed before. The carp, originally brought to Europe from China, and thence to the United Statcs as a foodfish, becomes in California a nuisanee, which ean not be cradicatcd, destroying the eggs and the foodstuff of far better fish.

In all monntain regions watcrfalls are likcly to oceur, and these serve as barricrs, preventing the aseent of trout and other fishes. On this aceount in the mountains of California, Colorado, Tyoming, and other States, hundreds of lakes and streams suitable for trout are found in which no fishes cver exist. In the Ycllowstone Park this fact is especially noticeablc. 'This region is a high volcanie platcau, formed by the filling of an ancient granite basin with a vast deposit of lava. The strcams of the park are very cold and clear, in every way favorable for the growth of trout; yet, with the cxecption of a single stream, the Yellowstone River, none of the streams was found to contain any fish in that part of it lying on the platcau. Below the plateau all of them are well stocked. The reason for this is ap- 


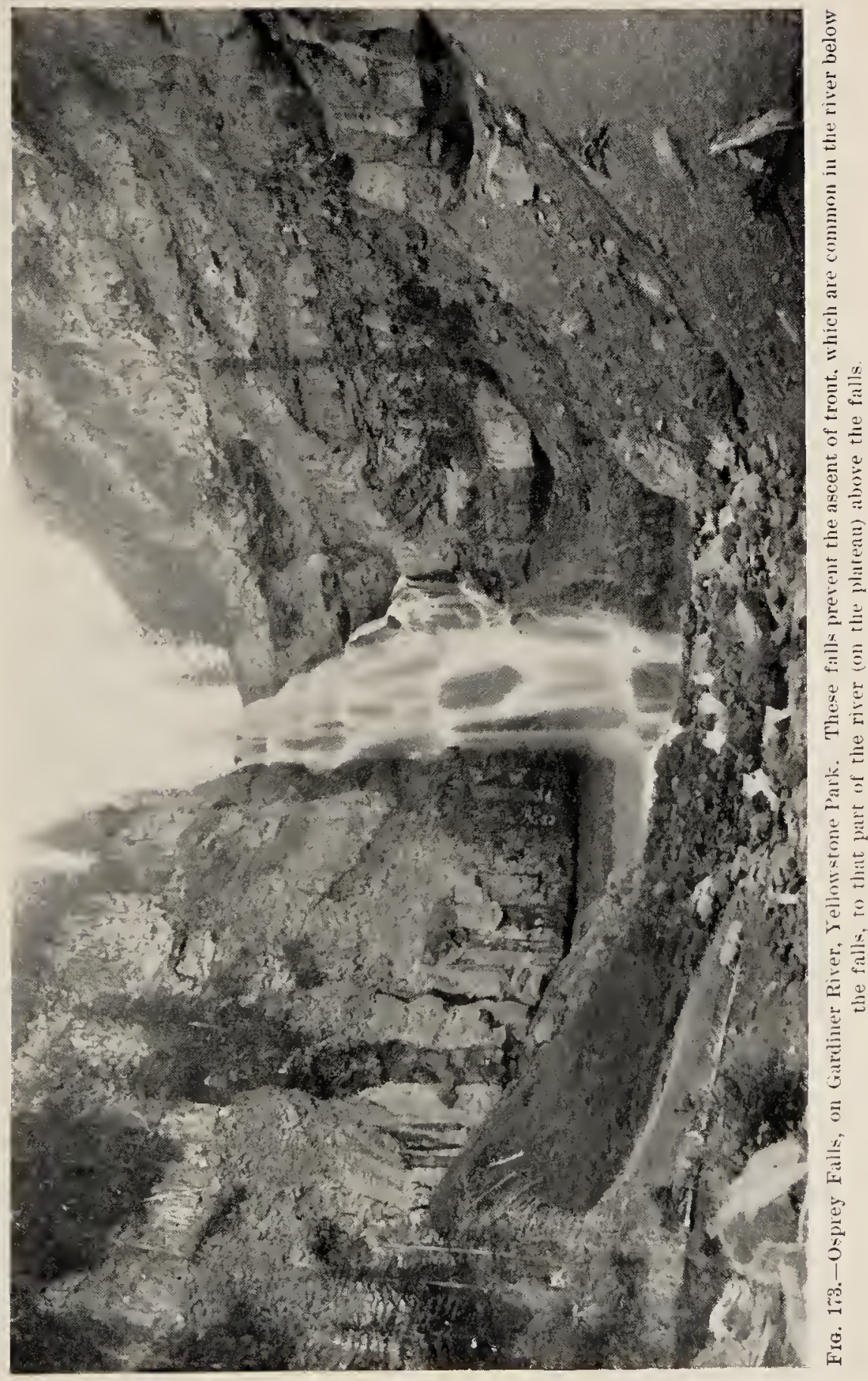


parent in the fact that the platean is fringed with cataracts which fishes can not ascend. Each stream has a cañon or deep gorge with a waterfall at its head, near the point where it leaves the hard bed of black lava for the rock below (Fig. 173). So for an area of fifteen hundred square miles within the Yellowstone National Park the streams were without trout because their natural inhabitants had never been able to reach them. When this state of things was diseovered it was easy to apply the remedy. Trout of different speeies were carried above the cascades, and these hare multiplied with great rapidity.

The exception noted above, that of the Yellowstone River itself, evidently needs explanation. An abundance of trout is found in this river both above and below the great falls, and no other fish occurs with it. This anomaly of distribution is readily explained by a study of the tributaries at the head waters of the river. When we aseend above Yellowstone Lake to the continental divide, we find on its very summit that only about an eighth of a mile of wet meadow and marsh, known as Two Oeean Pass (Fig. 1\%4), separates the dramage of the Yellowstone from that of the Columbia. A stream known as Atlantic Creek flows into the Jellowstone, while the waters of Pacific Creek on the other side find their way into the Snake River. 'These two crecks are eonneeted by waterways in the wet meadow, and trout may pass from one to the other without cheek. Thus from the Snake River the Yellowstone receired its tront, and from the Yellowstone they have spread to the streams tributiry to the upper Missouri.

'This ease is a type of the anomalies in distribution of which the student of zoögeography will find many. But aach effect depends upon some cause, and a thorough study of the surroundings or history of a species will show what this cause may be. In numerous cases in which fishes have beon found above an insumountable caseade, the cause is seen in a marsh flooded at high water, eomnecting one 


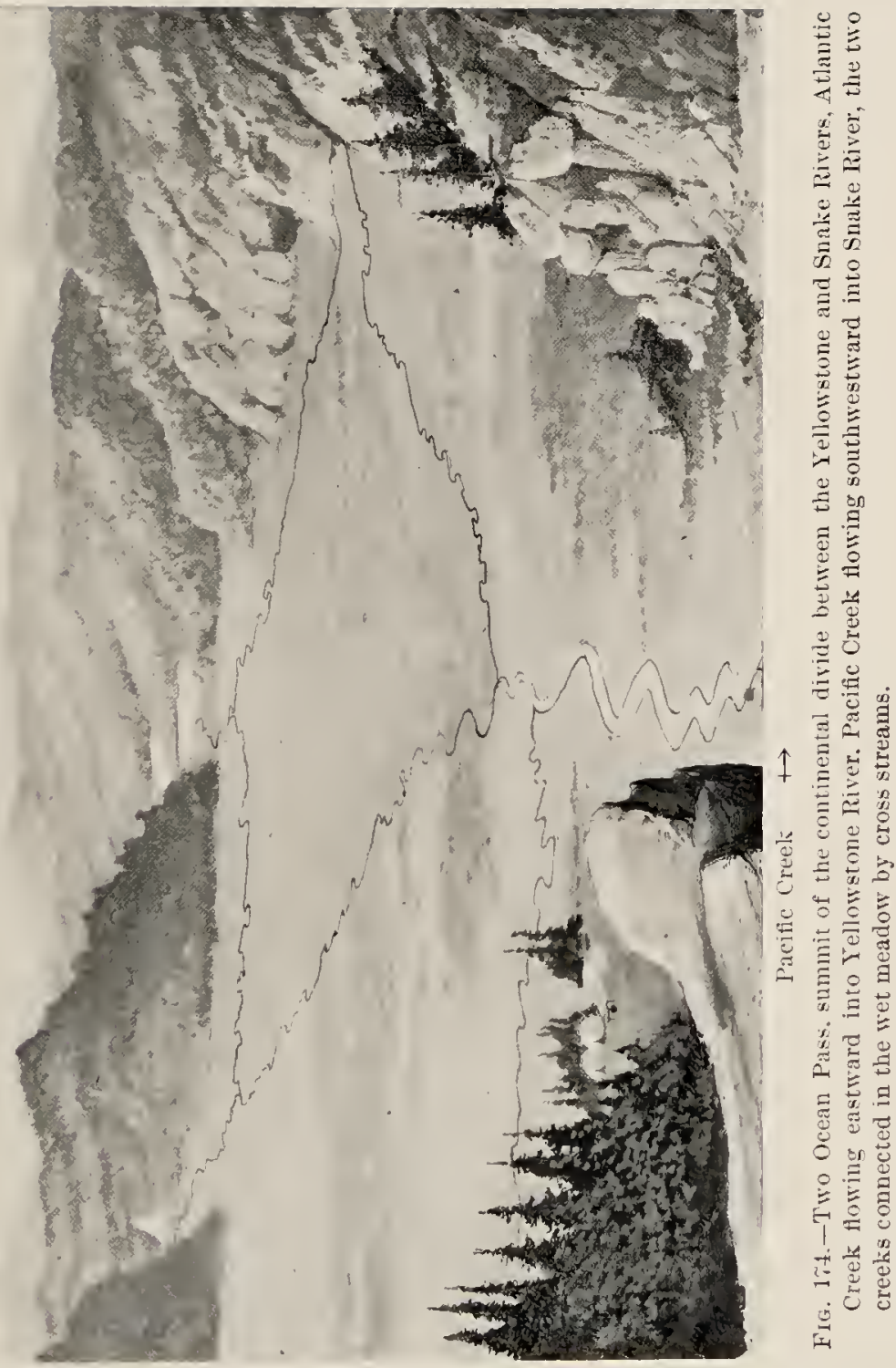


drainage basin with another. An example of this is found in Lava Creek in Tollowstone Park. Above Undine and Wraith Falls, both insurmountable, are found an abundance of trout. A marsh dry in summer connects Lava Creek with Black Tail Deer Creek, a tributary of the Yellowstone and without waterfall. From the Yellowstone through this creek and marsh the trout find their way into Lava Creck. In California numerons anomalics have becn noted, as the occurrence of Tahoe trout in Feather River and in the Blue Lakes of Amador, which are on the other side of the main crest of the Sierra Nevada from Lake Tahoc, and the occurrence of the Whitucy golden tront in Lone Pine Creek, another similar instance. In each case naturalists have found the man who actually carried the species across the divide. If this matter had been investigatcd a gencration latcr, these cases would have been unexplainable anomalies in geographical distribution. Real causes are almost always simple when they are once known.

The ways in which species may cross barriers in a state of Nature are as varied as the creatures themselves, and far more varied than the actual barriers. By the long-continued process of aljustment to conditions with the incessant destruction of the marlapted, the various organisms have beeone so well fitted to their surroundings that the casual observer may well suppose that each inhabits the region best fitted for it. Men hare even thought that the conditions of life have been fitted to the crcatures themselves, so perfect is this relation.

155. Character of barriers to distribution.-Taking the animal kingrom as a whole, the two great barriers modifying distribution ale the presence of the sea and ehanges in temperature. It is only in rare eases that any land animals can cross either of the great oceans, and these rare cases relate chiefly to the aretic regions. For this reason the land faunz of Africa, South America, and Australia 
have developed almost independently of one another. To the fresh-water fishes the sea forms equally a barrier, and

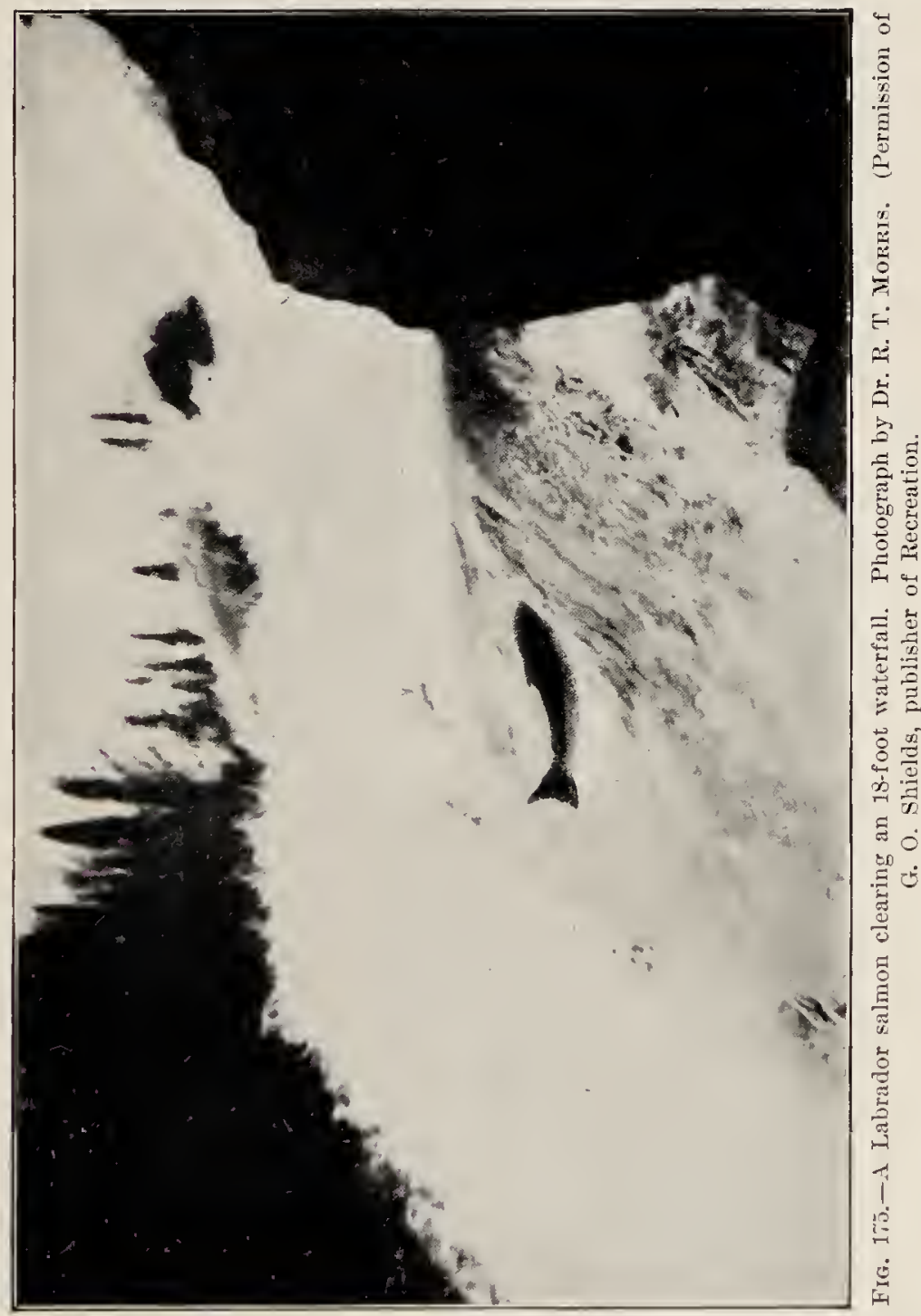

even the shore-fishes very rarely pass aeross great depths. Relatively few of the shore-fishes of Cuba, for example, ever eross the deep Florida Straits, and none of those of Cali- 
fornia ever reach IIonolnlu, nor are Hawaiian shore-fishes ever seen on the coast of California. For these reasons natural boundaries of the great realms of distribution are found in the sea.

The other great check to distribution is found in heat and cold. Most of the tropical animals can not endure frost. The aretic animals, however fierce or aetive, are enfeebled by heat. The timber line, north of which and above which frost oceurs the year round, thereforc serves

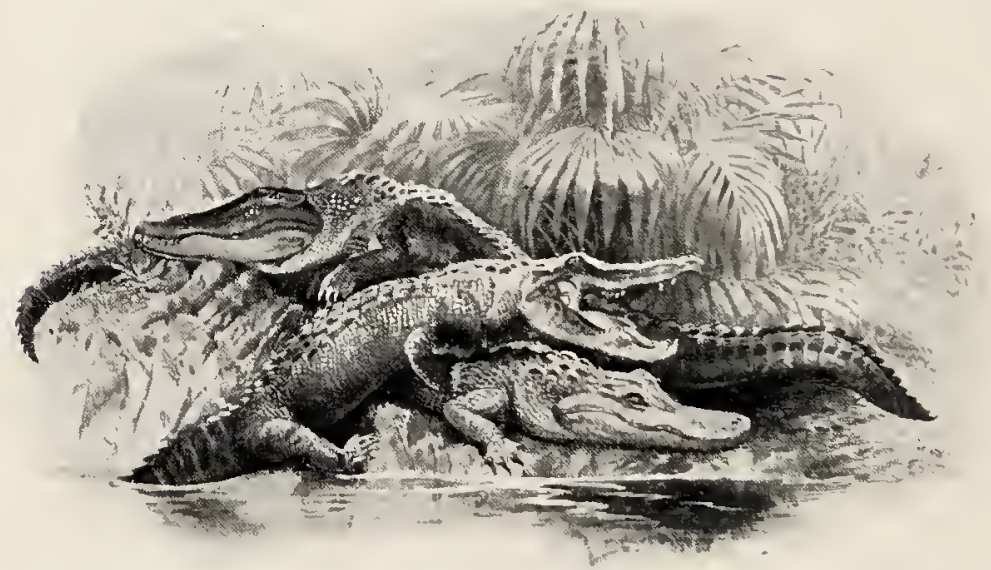

Fia. 176.-Alligators ; animals found only in the warm waters of tropical and subtropical regions.

as a boundary of limitation. Another equally marked is the frost line. Even the fislies of the tropies are extremely sensitive to slight cold. Off Florida Keys the cutlassfish is sometimes seen stiff and benumbed on the water, where the temperature is searcely below $60^{\circ}$ Falir. A "norther" on the Gulf of Mexieo will sometimes bring fisles which live in eonsiderable deptlss to the surfaee, throngh chilling the water. 'These barriers are rarely erossed by loealized species, but many forms, espeeially birds, keep within a relatively uniform temperature through migration. The summers are spent in the nortl or in the mountains, the winters in districts that are warmer. 
The climate, as distinct from the temperature, also greatly influenees many species. I.1 the Eastern United States and in the extreme Northwest, as in Europe and mueh of Asia, the atmosphere is humid all the year long. Rains occur at intervals in the summer, and rain or snow in the winter. The green season is from spring to fall, and the resting of plants is in the winter. To this condition the native animals adapt themselves, and this would seem to be the natural order of things.

But as we pass the Western plains of Nebraska, Kansas, and Texas this condition is materially changed. For part of the year rainfall is practically unknown. The air becomes dry, and under the eloudless sky the greater part of the vegetation ripens its seed and perishes. This is the arid climate. When the rainfall is very seant the region is never covered with verdure, and is known as desert. Sueh great desert tracts are found in parts of Wyoming, Utah, Nevada, Idaho, Colorado, Arizona, New Mexico, California, as well as in the northern parts of Mexico. In some eases the deserts are exposed to great heat, forming an ultra-torrid region, as in Death Talley in California and in eertain parts of Arizona.

But the arid region is not as a whole desolate. In many parts rain falls more or less heavily for part of the year, bringing a rank growth of annual grasses and of verdure in general. In California this rainfall is in the winter, the eoldest part of the year, and the eountry is green from November or October to June or May. In Mexico and northward to Colorado the ehief rainfall is in midsummer, the warmest part of the year, and the summer is the time of verdure.

To all these conditions the plant life must adapt itself and with this the animal life. But the species that have beeome fitted to the arid habitat have undergone some ehange in the process and may have beeome different speeies. It is, then, not easy for them to reeross the barrier 
of elimate to eompete with those forms already adapted. For this reason a marked change of elimate like a marked ehange of temperature forms a natural barrier to distribution and serves to eireumseribe a natural fauna.

Closely associated with climate is the nature of forest growth, the growth of grass, and in general the devclopment of conditions whieh serve for food or shelter to animals. These eonditions depend in part on soil, partly on elimate and topography, and partly on the aets of man. The forest and forest soils, acting like a great sponge, retain the waters of the rainy season, and thus regulate the size of the streams. The stream that ehanges least in rolume is most favorable to the life of fishes, frogs, and water animals generally. The destruction of forests on the mountain sides aets adversely to the life of these ereatures as well as to the interests of the farmer below whose lands the streams should water. When the forests are destroyed, the great host of wood ereatures, the bears, squirrels, warblers, various birds, beasts, and inseets of the woods ean no longer maintain themselves, and grow rare and disappear. For reasons that are obvious the conditions that produee forest, prairie, eanebrake, sage-desert, eactus-desert, and the like are potent in regulating the distribution of the speeies.

Still another set of eonditions depends on the food supply. The planting of orehards tends to multiply greatly the number of individuals of those speeies which prey upon fruit. When food is abundant the severity of the struggle for life is relaxed and individuals inerease in number. A speeies may be put to great stress by the disappearance of the animal or plant on which it has depended. Each ehange made by man annong the wild animals or plants may have far-reaching effects npon others. The coyote or prairic-wolf destroys sheep in the ranges of the West. It is thinned out by means of the bounty upon its scalp. Then the jack-rabbit, on which it also feeds, greatly in- 
creases in abundance, injuring fruit trees and grain fields. It is then necessary to pay for its destruction also.

To destroy hawks or owls beeause they catch chickens may inerease the numbers and destruetiveness of field-mice on which they also prey. To shoot robins, linnets, and other birds that destroy small fruits is likely to increase greatly the inseet pests on which these birds also feed. The inter-relations of species and species are so close that none should be exterminated by man unless its habits and relations have been subjected to eareful scientific study. Still less should any new ones be introduced without the fullest consideration of the possible results. For example, the mongoose, a weasel-like ereature, was introduced from India into Jamaica to kill rats and miee. It killed also the lizards, and thus produced a plague of fleas, an insect which the lizards kept in eheek. The English sparrow, introdueed that it might feed on insects inhabiting shade-trees, has become a nuisance, erowding out better birds and not aceomplishing the purpose for which it was brought to the United States.

T'o most kinds of animals a monntain range must act as a barrier to distribution. In a region laving high mountains a species will beeome in time split up into sereral, because the individuals in one valley will be isolated from those of another. The fauna of Califormia furnishes many illustrations of this, as among its mountain chains are many deep valleys shut off from eaeh other and having different peculiarities of temperaturc. For this reason two counties of California differ mueh more widely in their fanna than do two counties in Illinois. But Illinois as a whole has more different kinds of animals than California, beeause no barrier anywhere prevents their entrance. 'The State has, we may say, its doors wide open to immigrants from all quarters. The same is true of Iowa or of Kansas or Kentueky. Illinois has a rieher fauna than Iowa, because its extension is north and south, and it therefore 
covers a wider range of climate. Kentucky has a richer fauna than Iowa because it includes a greater variety of conditions. New England was called by Professor Agassiz a "zoölogical island," because of the relatively small number of its native animals, especially of species inhabiting its rivers. The cause of this is found in its isolation, being shut off from the Middle States by momntain ranges, while it is bounded on two sides by the sea.

156. Barriers affecting fresh-water animals. - The animals inhabiting fresh-water streams are affected by differences in temperature and elevation much as land animals are. They tend to spread from stream to stream whenever they can find their way. An isolated stream is likely to have its peculiar fauna just as island life is likely to differ from that of the mainland. The same species wanders widely within the limits of a single river basin. If a kind of fish establishes itself anywhere in the Mississippi Talley, it may find its way to every stream in the whole basin. If it likes cold spring water, as the rainbow-darter does, we may look for it in any cold spring. If, like the long-eared sun-fish, it frequents deep pools in the brooks, we may look for it moler roots of stumps and in every "swimming hole." If, like the chamnel-cat, it chooses the ripples of a river, we may fish for it wherever ripples are. The larger the whole river basin the more species find their way into it, and therefore the greater the number of species in any one of its streams.

Each species finds its habitat fitted to its life, and then in turn is forced to adapt itself to this habitat. Any other kind of habitat then appears as a barrier to its distribution. 'Thus to a fish of the ripples a stretch of still water' becomes a barrier. I species adapted to sandy bottoms will seldom force its way through swift waters or among weeds or rocks. The effect of waterfalls as barriers is elsewhere noticed. In some streams the dam made by a colony of beavers has the same effect. Mill-dams and artificial 
waterfalls have checked the morements of many species, while others have becn helped by artificial channels or canals. Streams that run muddy at times are not favorable for animal life. Still less favorable is the condition frequent in the arid region in which streams are full to the banks in the rainy season and shrunk to detached pools in the dry months.

The stream that has the grcatest variety of animals in it would be one (1) connected with a large river, (2) in a warm climate, (3) with clear water and (4) little fluctuation from winter to summer, (5) with little change in the clearncss of the watcr, (6) a gravelly bottom, (\%) preferably of limcstone, and (8) covered in its quiet reaches and its ripples with watcr-wceds. Thesc conditions arc best realized in tributaries of the Ohio, Cumberland, Tennessec, and Ozark Rivers among American streams, and it is in them that the greatest number of specics of fresh-water animals (fishes, cray-fishcs, mussels, etc.) has been recorded. These strcams approach most nearly to the idcal homes for animals of the fresh waters. The streams of Wisconsin, Michigan, and the Columbia region have many advantages, but are too cold. Those of Illinois, Iowa, northern Missouri, and Kansas are too sluggish, and sometimes rum mudrly. Those of Texas and California shrink too much in summer, and arc too isolated. The streams of the Atlantic coast are less isolated, but nonc connect with a great basin, and those of New England run too cold for the great mass of the species. For similar reasons the fresh-water animal life of Europe is relatively scanty, that of the Danube and Volga being richest. The animal life of the fresh watcr of South America centers in the Amazon, and that of Africa in the Nile, the Niger, and the Congo. The great rivers of Siberia, like the Yukon in Alaska and the Mackenzic River in British America, have but few forms of fresh-water animals, though those kinds fitted for life in cold, clear water exist in grcat abundance. 
15\%. Modes of distribution.-The means and modes of migration and distribution are obvious in the case of animals that can fly or swim or make long journeys on foot. An island can be visited and become peopled by birds from the nearest mainland. Fishes and marine mammals can travel from ocean to ocean. But many animals have no means of crossing watery barriers. "Oceanic islands, that have been formed de novo in mid-ocean and are not detached portions of pre-existing continents, are almost invariably free from such animals as are incapable of traversing the sea. If sufficiently distant from any continent, oceanic islands are generally without mammals, reptiles, and amphibia, but have both birds and insects and certain other invertebrates which are transported to them by involuntary migration."

As suggested in the last sentence, migration may be passive or involuntary. For example, those minute animals that can become dried $n \mathrm{p}$ and yet retain the power of renewing their active life under favorable conditions are sometimes carried in the dried mud adhering to the feet of birds, and may thus become widely distributed. Parasites are carried by their hosts in all their wanderings. Some animals, as rats and mice, are carricd by ships and railway trains and thus widely distributed.

158. Fauna and faunal areas.-The term fauna is applied to the animals of any region considered collectively. Thus the fauna of Illinois comprises the entire list of animals found naturally in that State. It includes the aboriginal men, the black benr, the fox, and all its animal life down to the Amoba. 'The relation of the fam of one region to that of another depends on the ease with which barriers may be crossed. Thus the fauna of Illinois differs little from that of Indiana or Jowa, because the State contains no barriers that animals may not readily pass. On the other hand, the fauna of California or Colorado differs materially from that of adjoining regions, because a moun- 
tainous country is full of barriers which obstruct the diffusion of life. Distinctness is in direct proportion to isolation. That is true in this regard of the fauna of any region is likewise true of its individual species. The degree of resemblance among individuals is in strict proportion to the freedom of their movements. Variation within the limits of a species is again proportionate to the barriers which prevent equal and free diffusion.

159. Realms of animal life.-The various divisions or realms into which the land surface of the earth may be divided on the basis of the character of animal life have their boundary in the obstacles offered to the spread of the average animal. In spite of great inequalities in this regard, we may yet roughly divide the land of the globe into seven principal realms or areas of distribution, each limited by barriers, of which the chief are the presence of the sea and the occurrence of frost. There are the Arctic, North Temperate, South American, Indo-African, Lemurian, Patagonian, and Australian realms. Of these the Australian roalm alone is sharply defined. Most of the others are surrounded by a broad fringe of debatable ground that forms a transition to some other zone.

The Arctic realm includes all the land area north of the isotherm of $32^{\circ}$. Its southern boundary corresponds closcly with the northern limit of trees. The fauna of this region is very homogeneous. It is not rich in species, most of the common types of life of warmer regions being excluded. Among the large animals are the polar bear, the walrus, and certain specics of "icc-riding" seals. Therc are a few species of fishes, mostly trout and sculpins, and a few insects. Some of thesc, as the mosquito, are excessively numerous in individuals. Reptiles arc absent from this region and many of its birds migrate southward in the winter, finding in the arctic only their breeding homes. When we consider the distribution of insects and other small animals of wide diffusion we must add to the arctic realm all high moun- 


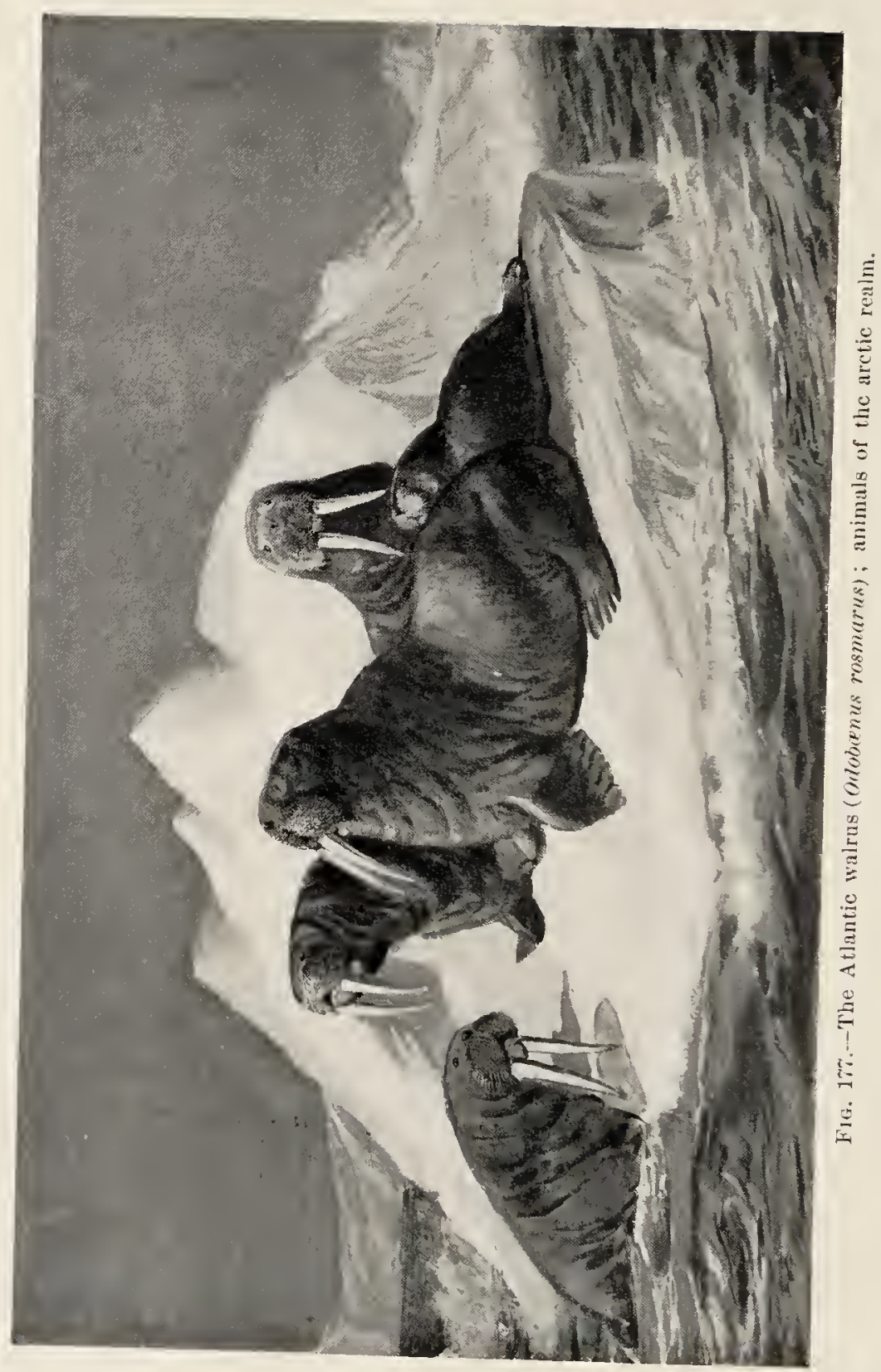


tains of other realms whose summits rise above the timber line. The characteristic large animals of the arctic, as the polar bear or the musk-ox or the reindeer, are not found there, because barriers shut them off. But the flora of the mountain top, even under the equator, may be characteristically arctic, and with the flowers of the north may be found the northern insects on whose presence the flower depends for its fertilization. So far as climate is concerned high altitude is equivalent to high latitude. On certain mountains the different zones of altitude and the corresponding zones of plant and insect life are very sharply defined (Fig. 178).

The North Temperate realm comprises all the land between the northern limit of trees and the sonthern limit of frost. It includes, therefore, nearly the whole of Europe, most of Asia, and most of North America. While there are large differences between the fauna of North America and that of Europe and Asia, these differences are of minor importance and are scarcely greater in any case than the difference between the fauna of California and that of our Atlantic coast. The close union of Alaska with Siberia gives the arctic region an almost continuous land area from Grecnland to the westward around to Norway. To the south everywhere in the temperate zone realm the species increase in number and variety, and the differences between the fauna of North America and that of Europe are due in part to the northward extension into the one and the other of types originating in the tropics. Especially is this true of certain of the dominant types of singing birds. The group of wood-warblers, tanagers, American orioles, vireos, mocking-birds, with the fly-catchers and humming-birds so characteristic of our forests, are umrepresented in Enrope. All of them are apparently immigrants from the neotropical realm where nearly all of them spend the winter. In the same way central Asia has many immigrants from the Indian realm to the southward. With all these variations there 


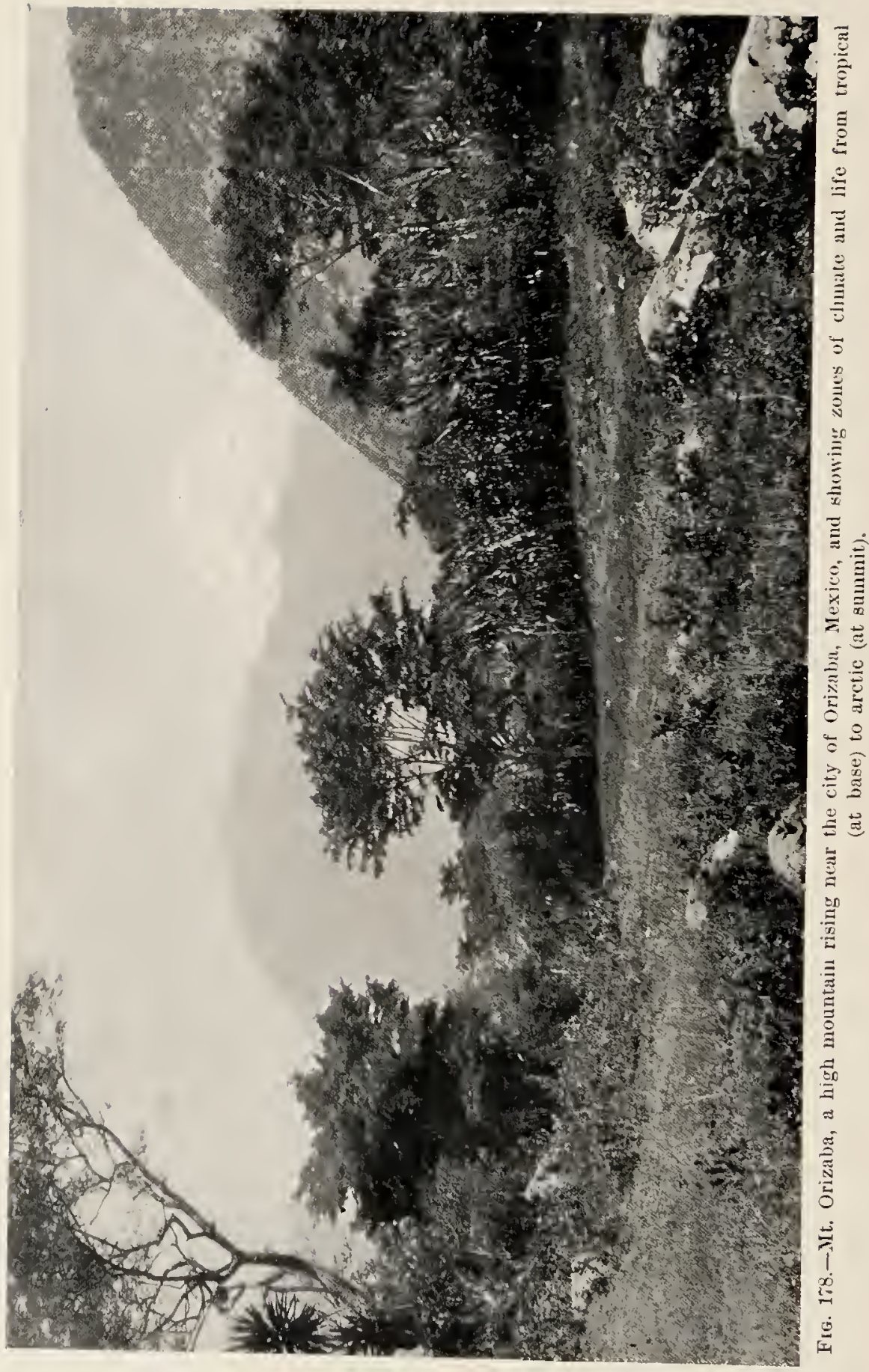


is an essential unity of life over this vast area, and the reeognition of North America as a separate (nearetic) realm, which some writers have attempted, seems hardly praetieable.

The Teotropical or South American realm ineludes Soutl Ameriea, the West Indies, the hot eoast lands of Mexieo, and those parts of Florida and Texas where frost does not oceur. Its boundaries through Mexico are not sharply defined, and there is mueh overlapping of the north temperate realm along its northern limit. Its birds especially range widely through the United States in the summer migrations, and a large part of them find in the North their breeding home. Southward, the broad barrier of the two oeeans keeps the South Ameriean famna very distinet from that of Afriea or Australia. The neotropical fanna is riehest of all in speeies. The great forests of the Amazon are the dreams of the naturalists. Charaeteristie types among the larger animals are the snout or broad-nosed (platyl'rhine) monkeys, whieh in many ways are very distinet from the monkeys and apes of the Old ITorld. In many of them the tip of the tail is highly speeialized and is used as a hand. The Edentates (armadillos, ant-eaters, ete.) are eharaeteristieally South Ameriean, and there are many peeuliar types of birds, reptiles, fishes, and inseets.

The Indo-A frican realm eorresponds to the neotropieal realm in position. It includes the greater part of Ifrica, merging gradually northward into the north temperate realm through the transition distriets whieh border the Mediterranean. It ineludes also Arabia, India, and the neighboring islands, all that part of Isia south of the limit of frost. In monkeys, carnivora, ungulates, and reptiles this region is wonderfully rieh. In variety of birds, fishes, and inseets the neotropieal realm exeeds it. The monkeys of this distriet are all of the narrow-nosed (eatarrhine) type, various forms being much more nearly related to man than is the ease with the peeuliar monkeys of Sonth 
America. Some of these (anthropoid apes) have much in common with man, and a primitive man derived from these has becn imagincd by Haeckel and others. No creature of this character is yet known, but that it may have once existed is not impossible. To this region belong the elephant, the rhinoceros, and the hippopotamus, as well as the lion, tiger, leopard, giraffe, the wild asses, and horses of various species, besides a large number of ruminant animals not found in other parts of the world. It is, in fact, in its lower mammals and reptiles that its

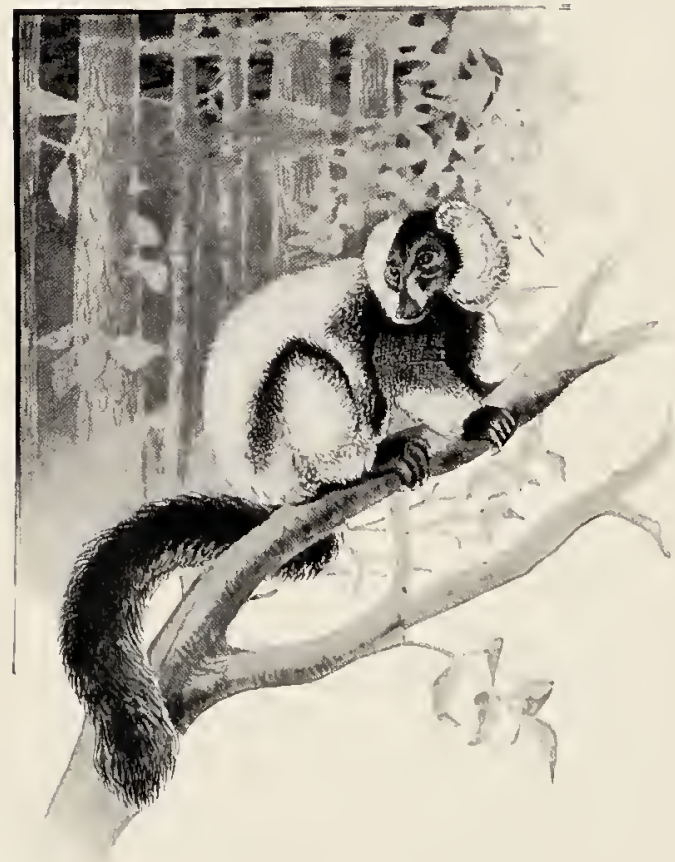

Fl(4. 1\%9.-A lemur (Lemur narius). most striking distiuctive characters are found. In its fish fauna it lias rery much in common with South Anrerica.

The Lemurian realm comprises Madagascar alone. It is an isolated dirision of the IndoAfrican realm, but the prosence of many specics of lemul and an unspecialized or primitive type of lemur is held to justify its recognition as a distinct realm. In most other groups of animals the fauna of Madaguscar is essentially that of neighboring parts of Africa.

The Patagonian realm includes the south temperate zone of South Amcrica. It has much in common with the neotropie:al realm from which its fauna is mainly derived, 
but the presence of frost is a barrier which vast numbers of species can not eross. Beyond the Patagonian realm lies the Antarctic eontinent. The scanty fama of this region is little known, and it probably differs from the Patagonian famna chiefly in the absence of all but the ice-riding speeies.

The Austratian realm comprises Australia and the neighboring islands. It is more isolated than any of the others, having been protected by the sea from the invasions of the characteristie animals of the Indo-African and temperate realms. It shows a singular persistence of low or primitive types of vertebrate life, as though in the process of evolution the region had been left a whole geological age behind the others. It is certain that if the elosely competing fauna of Africa and India could have been able to invade Australia, the dominant mammals and birds of that region would not have been left as they are now-marsupials and parrots.

It is only when barriers have shut out competition that simple or unspecialized types abound. The larger the land area and the more varied its surface, the greater is the stress of eompetition and the nore specialized are its characteristic forms. As part of this specialization is in the direction of hardiness and power to persist, the species from the large areas, as a whole, are least easy of extermination. The rapid multiplication of rabbits and foxes in Australia, when introduced by the hand of man, shows what might have taken place in this eomntry had not impassable barriers of ocean shut them out.

160. Subordinate realms or provinces. - Each of these great realms may be indefinitely subdivided into provinees and sections, for there is no end to the possibility of analysis. No school distriet has exactly the same animals or plants as any other, as finally in ultimate analysis we find that no two animals or plants are exactly alike. Shut off one pair of animals from the others of its species, and its dascendants will differ from the parent stock. This differ- 
ence increases with time and with distance so long as the separation is maintained. Hence new species and new fauna or aggregations of species are produced wherever free diffusion is checked by any kind of barrier.

161. Faunal areas of the sea.-In like manner, we may divide the oceans into faunal areas or zones, according to the distribution of its animals. For this purpose the fishes probably furnish the best indications, although results very similar are obtained when we consider the mollusks or the crustacea. The fresh-water fishes are not considered here, as in regard to their faunal areas they agree with the land animals of the same regions. Perhaps the most important basis for primary divisions is found in the separation from the localized shore-fishes of the cosmopolitan pelagic species, and the scarcely less widely distributed bassalian species or fishes of the deep sea.

The pelagic fishes are those which inhabit the open sea, swimming near the surface, and often in great schools. Such forms are mainly confined to the warmer waters. 'They are for the most part prediatory fishes, strong swimmers, and many of the species are found in all warm seas. Most species have special homing waters, to which they repair in the spawning season. Often there will be special regions to which they never resort, either for breeding or for food. At other times a certain species will appenr in numbers in regions where it has hitherto been muknown. For example, the frigate-mackerel (- uxis thazurd), homing in the Fast Indies and the Mediterranean, appeared in great numbers in 1880 off the coast of New England. Typical pelagic fishes are the mackerel, tmnny, dolphin, flyingfish, opah, and some species of shark. This group shades off by degrees into the ordinary shore-fish, some being partly pelagic, venturing out for short distances, and some are pelagic for part of the year only. To the free-swimming forms of classes of animals lower than fishes, found in the open ocean, the name Plankton is applied. 
The bassalian fauna, or deep-sea fauna, is composed of species inhabiting great depths (2,500 feet to 25,000 feet) in the sea. At a short distanee below the surfaee the ehange in temperature from day to night is no longer felt. At a still lower depth there is no difference between winter and summer, and still lower none between day and night. 'The bassalian fishes inhabit a region of great eold and inky darkness. Their bodies are subjeeted to great pressure, and the eonditions of life are practically unvarying. There is therefore among them no migration, no seasonal change, no spawning season fixed by outside eonditions, and no need of adaptation to varying environment. As a result, all are uniform indigo-blaek in eolor, and all show more or less degeneration in those charaeters associated with ordinary environment. Their bodies are elongate, from the lack of speeialization in the vertebrx. The flesh, being

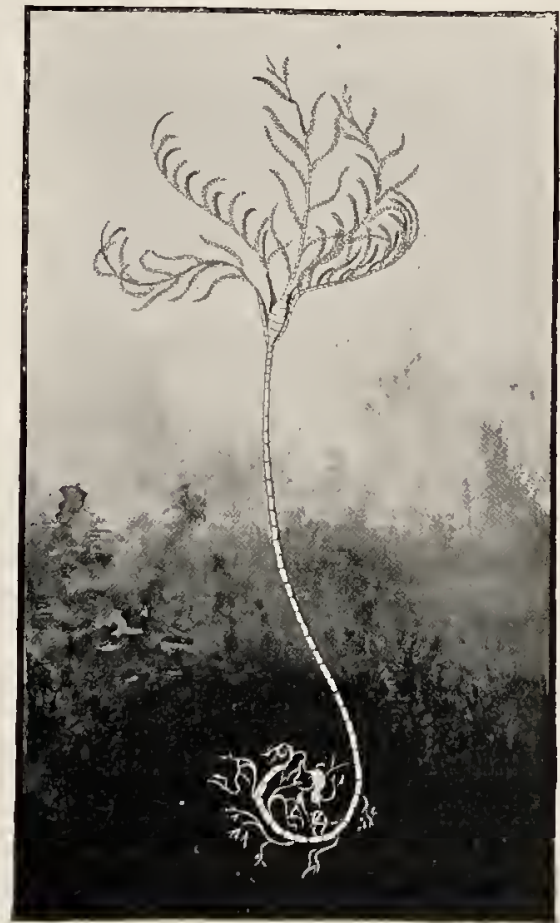

FIG, 180. - A crinoid (h/hazorimes loroten sis). A deep-sea animal which lives, fixed plant like, at the bottom of the ocean. held in place by the great pressure of the water, is soft and fragile. 'The organs of toueh are often highly developed. 'The eye is either' excessively large, as if to eateh the slightest ray of light, or else it is undeveloped, as if the fish had abandoned the effort to see. In many eases luminous spots or lanterns are developed by whieh the fish may see to guide his way in the 
sea, and in some forms these shining appendages are highly developed. In one form (Lthoprora) a luminous body corers the end of the nose, like the head-light of an engine. In another (Ipnops) the two eyes themselres are flattened out, covering the whole top of the heal, and are luminous in life. Many of these species have excessively large teeth, and some have been known to swallow animals actually larger than themselres. Those which have lantern-like spots have always large eyes.

The deep-sea fishes, however fantastic, have all near relatives among the shore forms. Mlost of them are degenerate representatives of well-known species-for example, of eels, cod, smelt, grenadiers, semlpin, and flomders. The deep-sea crustaceans and mollusks are similarly related to shore forms.

The third great subdivision of marine animals is the littoral or shore group, those living in water of moderate depth, never venturing fal into the open sea either at the surface or in the depths. This group shades into both the preceding. 'The individuals of some of the species are excessively local, remaining their life long in tide pools or coral reefs or piles of rock. Other's renture far from home, and might well be classed as pelagic. Still others ascend rivers either to spawn (anadromous, as the salmon, shad, and striped bass), or for purposes of feeding, as the robalo, corvina, and other shore-fishes of the tropies. Some live among rocks alone, some in sei-weed, some on sandy shores, some in the surf, and some only in sheltered lagoons. In all seas there are fishes and other marine animals, and each creature ham the places for which it is fitted. 


\section{CLASSIFICATION OF ANIMALS*}

In this diagram of classification every animal referred to in this book, either by its vernueular or its scientific name, is assigned to its proper class and branch. Of the species mentioned by their seientific names, only the genus name is given in this list.

\section{KINGDOM ANIMALIA}

\section{BRANCH I. PROTOZOA}

Class I. Rhīzŏp'oda.

Amœ'ba, Globigerīn

Class II. Mycētozōa.

Cllass III. Mastigðph'ora.

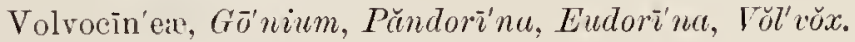

Class IV. Spōrozōa.

Grĕgarīna.

Class V. Infusōria.

Püramócium, Vorticěll'la.

\section{BRANCII II. PORIF'ERA}

\section{Class I. Porifera.}

Sponges, Călcoly̆n'thus, Prophysē'ma, Spongĭlla, Sponigia, Clīona.

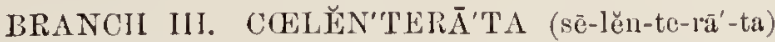

\section{Class I. Hȳdrozōa.}

IIȳ'dra, Eucō'pe, Sīphōnŏph'ora, Phȳsŏph'ora, Obē'liu, sea-anĕm'one, pŏl'yp, Phīssā'lia, Pürapŭg'urus.

Class II. Scȳphozōa (sī-fō-zō'-a).

Jelly-fish, Lizz'zia.

Cluss III. Actinozōa.

Cŏrals, Mètrǔdium.

Class IV. Ctěnǒph'ora (těn-ŏph'-o-ra).

* The arrangement of hranches (or phyla) and classes here used is that adopted in Parker and IIaswell's Text-Book of Zoölogy (1897). 


\section{BIANCII IV. PLĂTYIĚLHǏN'THES}

Class I. Turbellā'ria.

Plan̄̄'ria.

ClaAsS II. Trĕmatō'da.

Class III. Cěstō'da.

'Tape-worm, Tae'nia, Lăg'ula, flat-worm.

A ppendix to Platyelinthes-C'lass Nemertǐn'ea.

\section{BRANCH V. NĔHATHĚLHǏN"THES}

C'laAss I. Nĕmatō'da.

Sy̆n'gamus, round-worm, Trŭchïna, Böthriocĕphialus, pupworm, Uncènū'ria.

Class II. Acanthocĕph'ala.

C'lass III. Chætŏg' natha (kē-tŏg'-na-tha).

\section{BRANCII VI. TROCIELAIYN"TIES}

Class I. Rotif'era.

Rotutōria.

Class II. Dīnophì'lea.

Class III. Gastrǒt'richa.

\section{BRANCH VII, HǑLLUSCOI'DA}

Cluss I. Pǒlyzōa.

Cunss Il. Phōrŏnida.

CLASS III. Brăchiǒp'oda.

\section{BR.ANCI VHI. ĔCHY̌NŌDĔR'AITA}

ChASS I. Asteroi'dea.

Startish.

('uass II. Ophiuroi'dea.

CLASS III. Ëchinoi'dea.

Sot-urchin.

Crass IV. Hölothuroi'dea.

Seit-encumber.

Class V. Crīnoi'dea.

Crinnid, lihzōōerē'nus.

Class VI. Cüstoi'dea.

Cluass VII. Blăstoi'dea. 


\section{BRANCH IX. ANNULĀ'TA}

Class I. Chætŏp'oda (kē-tŏp'-o-da).

Earth-worm.

A prendix to the Chetopoda-Class Mȳzostŏmida.

Class II. Gĕphyrēa (jĕf-e-rēé-a).

Class III. Archi-annĕlida.

('Lass IV. Hĭrudin'ea.

BRANCH X. ARTHRŎP'ODA

\section{Class I. Crustā'cea.}

Lobster, cray-fish, crab, bar'nacle, Lè̈ pas, hermit-crab, Păg'urus, pea-crab, P̌̌nnothé'res, Epizoăn'thus, fish-lice, whale-lice, Sacculìna, Lernceŏcera, prawn, Penē us.

Appendix to Crustacea-Class Trïlobíta.

CLASs II. Ŏnychǒph'ora.

Class III. My̆riăp'oda.

Cĕn'tipèd.

Class IV. Insĕc'ta.

Water-beetle, water-bug, canker-worm moth, bce, white ant, cockroach, mosquito. wecvil, grasshopper, eaterpillar, butterfly, katydid, bcetle, Iॅ̆p'tera, Lępidðp'tera, monarch butterfly, Anō'sia, Cu'lex, Melăn'oplus, May-fly, locust, cottony-cushion seale, Icë'rya, lady-bird, Vēdālia, praying-horse, Măn'tis, Sër'plıus, Céerō'pia, gall insect, An'dricus, mole-cricket, Grÿllotül'pa, IIȳdrŏph'ilus, Prōónus, Camponötus, plant-lice, Āpl'ida, Cóe'eida, Āphis-lion, ant, Ec'iton, termite, bumble-bee, earpenter-bee, André'ma, IIaľ̌c'tus, yellow-jacket, hornet, Těs'pa, wasp, Át'ta, bird-lice, Mallöph'aga, flea, louse, Pedic'utus, Lipeu'rus, IIȳmenŏp'tere, ichnemmon

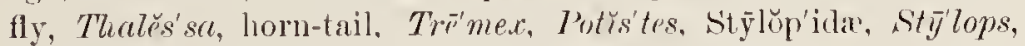
red orange-scale, toad-bug, Găl'gulus, inch-worm, span-worm, gennetrid, walking-stick, Diapherǒn'era, Pliy̆lium, meadow brown, Grăp'ta, Kăl'lima, sphinx-moth, tomato-worm, Phlégethŏn'tius, puss-moth, Cerü'ra, viceroy butterfly, Bäsitar'chia, Dan'ì'idx, Ilelieŏn'ide, Piěr'ida, Pạı̆liŏn'idx, Syr'phida, flower-flies, trec-hopper, Membrăc'ida, IIemřp'tera, San'ba (saw'-ha), earrionbeetle, Callosī'mia, promét thea, cricket, cicī'da, dragon-fly, Cynīp'idle, Hessian-fly, mud-dauber, Lerë'ma, Ery̆n'nis, skipper butterfly, Schistocér'ca.

Class V. Arăch'nida.

Tardl̆g'rada, bear-animalcule, scorpion, Lyeŏs'idx, tick, itchmite, Sarcŏp'tes, spider, trap-door spider, turret-spider, Ctenť $z \alpha$. 


\section{BRANCII XI. MŎLLŬS'CA}

\section{Class I. Pĕlecy̆póoda.}

Clam, pond-mussel, $L_{i}^{\prime} m a$.

Class II. Amphineu'ra.

Class III. Gaströp'oda.

Pond-suail, Lymux'us, whelk.

Appendix to the Gastropona-Class Scaphŏp'oda and Rhö dope. CuAss IV. Cěphalöp'oda.

\section{BRANCII XII. CILORDÁ'TA}

\section{Sub-Branch I. Adělochǒr'da. Class Adelorhorda.}

Sub-Branch II. Urochor'da. Class Urochorda.

Sea-squirts, 'Tunicā'ta.

Sub-branch I1T. Vertebrāta. Divisioñ A. Acrānia. Class Acrania. Division B. Crāniāta.

\section{Class I. Cỹclostŏm'ata.}

Class II. Pŭs'ces (p̌̀s'-sēz).

Codfish, seulpin, skate, lady-fish, $\breve{A} l^{\prime} b u l a$, sword-fish, Xrph'ias, flounder, Platöphirys, Salanx, Cöt'tus, blob, niller"s-thumb, conger-eel, Rëmiora, Exoco'tus, flying-fish, Cypselu'rus (š̄p-sc-hu rns), decp-sea angler, lantern-fish, Corynŏlophus, Echros'toma, AEthöphira, nokee, seorpion-fish, Emmydrachthys, mad-tom, Schilbeódes, eat-fish, horned pout, toal-fish, sting-l:ay, globe-fish, poreupine-fish, torpedo, electric eel, electric cut-fish, star-gazer, electric lay, Grǒt'ophus, Díorlon. Narcìné, Rǘja, black-fish, mud-fish, tront, Săt'mo, chub, hormed dace. Eehcueidida Amphimrion, $N^{-}$meas, hag-fish, Myxíne, Heptatréma, Iolistotrëma, lamprey, Oligocont'tus, mousc-tish, lava-fish, Pterophrīne, pipe-fish, Phyllöp'teryx, anglers, l,öplius, Antennērrius, Ceratiile, minnow, mackerel, sweker, salmon, shad, alewife, sturgeon, striped bass, quin'nat, cel, sun-fish, stickle-back, carp, cutlass-fish, rainbow darter, channel-cat, Ar'xis, tumy, dolphin, opah, shark, Asthopmo'ra. Ïp'nops, eorl, smelt, grenadier, rōb'alo, corvinua, Chölogŭs'ter, TY̌phlích'thy̆s, blind-fish.

Clast IIl. Amphib'ia.

Toad, frog, salamander, tree-frog, $I \bar{y}^{\prime} 7 a$.

\section{Cluass IV. Reptǐl'ia.}

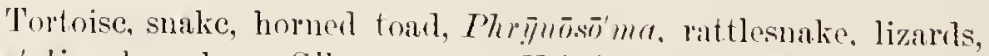
An'olis, chamcleon, Gila monster, Hèloděr'ma, Élaps, coralúl'los, Lămpropĕl'tis, Osceŏla, alliğntor. 


\section{Class V. Ä'ves.}

Bird-of-paradise, peacock, pheasant, robin, pigeon, chicken, eagle, vulture, guil'leınot (gĭl'-e-mŏt), murre (mŭr), auk, ful'mar, pět'rel, sparrow, bluebird, woodpecker, owl, Colŭm'ba, pelican, Delaněr'pes, cormorant, mcadow-lark, warbler, turkcy, Canada jay, black duck, Perisō'reus, Lria, cow-bird, cuckoo, parrot, ptarmigan, whippoorwill, Antrǒs'tomus, gull, tcrn, fly-catcher, bittern, mocking-bircl, shrike, bobolink, goose, humming-bird, oriole, puffin, tailor-bird, king-bird, nightingale, starling, skylark, passenger-pigeon, ouzel (ooz'-el), linnet, tanager, vireo, wood-warbler, Mhülacrŏ'corax, Trǒch'ilus. Ornithŏt'omus, I'saltrĭp'arus.

\section{Class VI. Mammā'lia.}

Horse, ram, fur-seal, rabbit, cat, ox, tiger, lion, sheep, elephant, whale, bear, wolf, squirrel, lĕm'ming, fox, dog, weasel, stoat, rcindecr, otter, ant-eater, giraffe', skunk, poreupine, helgehog, armadillo, Callorhënus, sea-lion, decr, buffalo, kangaroo, Măc'ropus, duck-bill, Mlón'otrēme, monkey, gopher, elk, bison, prairic-dog, big-horn, harc, antelope, black-tail leer, hound, mole, hycna, micc, rodent, woodchuck, jack-rabbit, Macä'cus, Cěrcopüth'ecus, bcaver, wood-rat, pocket-gopher, coyo'te, civet-cat, flying-fox, mŏn'goose, sca-cow, Trül'pes, walrus, musk-ox, ape, rhīnŏe'cros, hŭppopŏt'amus, leopard, ass, lëmur, T'rǔch'échus, manatee, Léépus, Odōbce'nus, Lémur. 



\section{GLOSSARY}

[Only those terms are defined in this glossary that are not explained in the text. In the case of the terms defined or explained in the text, reference is made to the number of the paragraph in which the explanation occurs. The pronumciation of the vernacular and scientific names of the animals mentioned in the text is given in the Classification.]

Ăbomā'sum : 42 .

Adaptation: $6 \%$. 74 .

Albuminous : said of substances containing albumen,

Aliměn'tary canal : 42 .

Alluring coloration: 111 .

Altrǐc'ial : 79.

Altruis'tic instinct: 129.

Amœ'boid: having the changing form of an Amoba.

Anăd'romous: said of fishes that go from the sea up rivers to lay their eggs.

Anăt'omy : 39.

Animăl'cule: an animal of microseopie smalhness.

Antern næ: the "feelers," the most anterior pair of appendages of insects and insect-like animals; situated on the hearl, and the seat of organs of speeial sense.

Ăn thropoid : man-like.

$\bar{A}$ 'nus: 42 .

Appěn'dix vermiror'mis : 82 .

Artificial selection: 72 .

Assimmilate : to receive fool and transform it into a homogenous part of the bolly substance.

Atŏll' : a ring-shaped coral island nearly or quite inclosing a lngoon.

At'rophy : a stoppage of the growth or development of a part or organ.

Auditory : referring to the sense of hearing.

Autŏm'atism : the state of being automatie; involuntary action. 
Bassā'lian : 160.

Bīŏl'ogist : student of animals and plants.

Blăs'tōderm : 50.

Blăs'tula : 50 .

Budding : the process of reproduction among animals in which a suall part of the body substance of an animal grows out from the surface, separates from the parent, and develops into a new individual.

Cæ'cum (sē-kum) : 42 .

Carnǐv'orous: flesh-eating.

Căt arrhìne: nostril downward; said of the narrow-nosed Old-World monkeys.

Cell : 2 .

Cěllulose : a peculiar compound insoluble in all ordinary solvents, forming the fundamental material of the structure of plants, and also contained in the mantle of tunicates.

Chī'tin : $5 \%$.

Chlō'rophy̆ll : 13.

Chrō'matophore : a color-bearing granule or sac.

Chrō'mosome: 2.

Chry̆s'alis : $5 \%$.

Chy̆le: 42.

Cǔl ia: 5.

Cleavage : 50 .

Cō'lon : 42.

Comměn'salism : 90.

Crom'munal : 83.

Conjugātion : 5 .

Contractile vacuole: a vacunle that dilates and contracts regularly, and is supposed to have an exeretory function.

Cy̆st: 98.

Cȳtoplasm : 2.

Degeneration : 95 .

Development: 46.

Differentiation: the setting apart of special organs for special work; frogressive eliange from general to special: specialization.

Digestion: the process of dissolving and chemically changing food so that it an be assinilated by the blood and fumish nutriment to the borly.

Dìmor' phism : 24 .

Divertǐc'ulum : a blind pouch arising from another larger pouch. 44.

Duodē'num : 42. 
Ěć tōblast: 50.

Ëctōiderm: 20 .

Egg-cell : 20.

Egoǔs'tic instinct : 129.

Embry̆ŏl'ogy : 39.

Embryŏn'ic : 49.

En'dōblast : 50 .

Ën'dōderm : 20.

Envīronment : an organism's surroundings taken colleetively.

Ex'cretory: referring to excretion, as exeretory organs, the organs which get rid of waste matter in the animal body.

Fau'na (fawna): $15 \%$

Fertilized egg : 20.

Fission: 4 .

Flagěl'la : 13 .

Function: $3 \%$.

Găn'glion (pl. ganglia) : a nerve-eenter composed of an aggregation of nerve-eells.

Găs'trula : 50 .

Gěm'mule : 20.

Generalization : 41 .

Gēŏl'ogist: student of the strueture and history of the earth.

Grēgā'rious: 87.

Growth : 46.

Habit: 139.

Herbǐv'orous : plant-eating.

Herèd'ity : 54.

Fermăphrodǐt ic : 35.

Hibernātion: passing the winter in a death-like sleep.

Hōmogè'neous: of the same eomprosition or structure throughout.

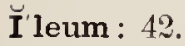

Inorganic: not being nor having been a living organism; not organie.

Insectiv' orous : insect-eating.

Instinct: 128.

Intellect : 139 .

Intercěl'lular: outside of and between the eells.

Jeju'num : 42. 
Lagoon' : a pool or lake; the still water inclosed within an atoll.

Lar'va: $5 \%$.

Lěpidŏp'terous : referring to the Lepidoptera, or moths and butterflies.

Lit' toral : 160.

Lu'men: the cavity of a tubular organ. 44.

Medu'sa: 24 .

Mĕg alops : 59.

Mĕs'oderm : 20.

Mĕtăbolism : the act or process by which dead food is built up into living matter, and living matter is broken down into simpler produets within a cell or organism.

Mĕtamor' phosis : 56.

Mìgration : $; 0$.

Mill'limeter : about one twenty-fifth of an inch; a term nsed in the metrie system of measure.

Mím' icry : 112.

Mind: 140.

Molt : $5 \%$.

Mŏnŏg'amous: said of animals in whieh a male mates with only a single female.

Multiplication: used in the text usually synonymonsly with reproduction.

My̆rmecŏph'ilons : said of insects which are fonnd inhabiting the nests of ants.

Natural selection: 70 .

Nótochord: an chastie rod, or row of eells, formed in the early embryo of chordateanimals (ineluding all the vertehrates and some others), which lies betow the dursal nervous tube and above the ventral alimentary tube.

Nu'cleus (1). nuclei) : 2.

Essǒph'agus : 4ঐ.

Olfactory: referring to the sense of smell.

Omā'sum : 42.

Organ: $3 \%$

Organic: referring to the matter of which animals and plants are eomjused.

Organism: a living being, plant or animal.

Orientātion: 9.5.

O tolith : 121 . 
Papull la (pl. papillæ) : a small nipple-like process, as the papillae of the skin or tongue.

Parasite: 93 .

Parthěnogěn esis : 35.

Pĕlăg'ic: inhabiting the surface of mid-ocean. 160.

Phar'ynx : 42.

Phy̌sičl'ogy: 39.

Plăt'yrrhine: iroad-nosed; said of the New-World monkeys.

Plu'teus: 59.

Poly̆g'amous: said of animals in which a single male mates with several females: 35.

Pŏlymor phism : 24.

Pől yp : 21.

Post-embryonic : 49

Præcō cial (¡pr'-co'-shal) : 79.

Prĕd atory : feeding on other animals.

Prō polis: 84.

Protective resemblance: $10 \%$.

Prōtoplasm : 2.

Prōventric'ulus : 42.

Pseu'dopod : 4.

Psȳ'chic: 140.

Pu pa: 57.

Reason : 199.

Recognition marls: $77,115$.

Rĕc'tum : 42.

Reflex action: $12 \%$.

Reproduction : $6 \%$.

Respiration: 4.

Retǐc'ulum : 42.

Rĕt ina: 123.

Ru'men: 42.

Ru'minant : 42 .

Salī'va : 42 .

Sensation : 67 .

Sensorium : 126.

Sil'ica: the mincral of which quartz, sand, flint, cte., are composed.

Spawn, v. : to lay eggr.

Specialization: 41 .

Species : 151. 
Sperm cell : 20 .

Spir'acle: one of the breathing openings of an insect situated on the side of the abtomen or thorax.

Spon' gin : 20.

Stimulus (pl. stimuli): that which excites action in plant or animal tissue.

Strā'ta : layer's, usually said of rocks.

Strǐdulāition: 12:.

Sub-species : 151.

Sy̆mbiō'sis : 90.

Tactile: referring to the sense of toneh. 118.

Tadpole: 58 .

Tĕn tacle: a protruding flexible proeess or appendage, usually of the heal of invertebrate animals, being used as an organ of toneh, prehension, or motion.

Tĕrmitŏph'ilous : said of insects inhabiting the nests of termites.

Văc'uole: a minute eavity containing air, water. or a chemical secretion of the protopiasm, found in an organ, tissue, or cell.

Vestı̆g'ial : 83 .

Vis'cera: the organs in the great eavities of the body, commonly used for the organs in the abdominat cavity.

Yōllk (yūk) : 48.

Zoē'a : 59.

Zōogeŏg'raphy : 147.

Zōoid : one of the more or less inderendent members of a eolonial or rompound ormanism.

Zōobl'ogist : a student of amimals. 


\section{N D E X}

Abonasum, 68 .

Actinocephalus oligacanthus (ill.), 14.

Adaptations, 113, 123; classification of, 12:3; eoncerned wilh surroundings, $14: 3$; degree of struetural clunge in, 146 ; for defense of young. 137 ; for rivalry, 135 ; for self-defense, 128 ; for securing food, 125 ; origilu of, $12: 3$. Agassiz's cave-fish (illus.), 282. Albula vulpes, metamorplosis of (illus.), 98.

Alimentary canal, 66 ; of cockroath (illus.), 73 ; of earthworm (illus.), 71 ; of flatworm (illus.), 70 ; of Holothurian (illus.), 70 ; of mussel (illus.), 72: of Obelia (illus.), 69; of ox (illus.), 67 ; of Planaria (illus.), 70 ; of scaenculubel (illus.). $\% 0$.

Alligator (illus.), 290.

Alluring coloration, 216.

Alternation of gencrations, 42.

Altricial, 140.

Amoba, 5.

Amoba polyporia (illus.), 8.

Anatomy, 64.

Andrena, nest of (illus.). 160.

Andricus californicus, galls of (illus.), 143.
Angler, deep-sen (illus.), 124.

Animals, life of simplest, 1 ; manycelled, 2 ; one-celled, 2 ; slightly complex, 24.

Anosia plexippus, netamorplosis of (illus.), 92 ; minicked by $B a$ silarchia archippus (illus.). 219.

Antemma of eray-fish (illus.), 233 ; of leaf-eating beetle (illus.), 230 . Antemna, speeialized, of promethea moth (illus.), 281.

Antrostomus vociferus (illus.), 203. Auts (illus.), 155.

Anus, 68.

Appearance, terrifying 212.

Arctic realin. $29 \%$.

Area, fammal. 206.

Artificial selection, 120 .

Atoll (illus.), 44.

Auditory organ of cray-fish (illus.), 253: of ericliet (illus.), 234; of grasshopper (illus.), :344; of mollusk (illus.), 233; of mosqnito (illus.), 235.

Auditory organs, 232.

Anstralian realı, 303.

Barbadoes earth, 19.

Barnacle, adtult and latra (illus.). 195; metamorphosis of (illus.), 101. 
Barrier, mountains a, to distribution, 293 ; sea a, to distribution, 288 ; temperature a, to distribution, 290.

Barriers affecting fresh-water animals, 294 ; effect of, 283 ; species debarred by, 274; to distribution, character of, 288.

Basilarchia archippus mimicking Anosia plexippus (illus.), 219.

Bassalian fauna, 305.

Beavers, nest of (illus.), 269.

Beetle, larva of (illus.), 146.

Beetles, lady-bird (illus.), 214.

Bird, egg of (illus.), 79.

Bird-louse (illus.), 188.

Bird of paradise (illus.), 58 .

Birds, nest-maling habits of, 264 .

Birth, 78.

Bitteru, nestlings of (illus.), 246, 247.

Blastoderm, 82.

Blastula, 82.

Brain, 241.

Budding. 13.

Bumble-bee, 159, (illus.), 161.

Bush-tit, nest of California (illus.), 270.

Butterfly, egg of (illus.), 79 : monalrch, inctamorphosis of (illus.), 92.

Ceermin, 68.

Calcolynthus porimigenius (illus.), 33.

Calf, taste buds of (illus.), 229.

Cullortinus alasconus (illus.), 136.

Camponotus (illus.), 155.

Canada jay (illus.), 138.

Canadian skipper butterfly, distribution of (illus.), 273.
Canal, alimentary, 66.

Cankerworm-moth (illus.), 59.

Care of young of mammals, 268 .

Carpenter-bee, nest of (illus.), 160.

Caterpillar parasitized (illus.), 189, (illus.), 190.

Cave blind-fish (illus.), 282.

Cecropia (illus.), 141.

Cell, animal, 2 ; egg, 21, 56 ; plant, 2 ; products, 3 ; wall, 3.

Cells, brood, of honey-bee (illus.), 152 ; nerve, 240 ; reproductive, $29,55$.

Cellulose, 24, 2\%.

Centiped (illus.), 130.

Cerura, larra of (illus.), 216.

Chalk, 18.

Chick, embryonic stages of (illus.), 87.

Chitin, 91.

Chlorophyll, 24 .

Chologaster agassizi (illus.), 282.

Chologaster avitus (illus.), 282.

Chromatophore, 24 .

Chromosome, 3.

Chrysalid of butterfly, showing protective resemblance (illus.), 206.

Chrysalis, 93.

Chyle, 68.

Cilia, 9.

Cleavage, 82.

Climate, influeneing distribution, 291 : instincts of, 248.

Clouded skipper butterfly, distribution of (illus.), 278.

Coccidium oviforme (illus.), 14.

Cockroach, alimentary eanal of (illus.), 73; egg case of (illus.), 140.

Cocoon of Cecropia moth (illus.), 141. 
Colon, 68.

Colonial jelly-fishes, 45 ; Protozoa, 24.

Colony, 31.

Color, 222.

Coloration, alluring, 216.

Colors, warning, 212.

Commensalism, 172, 173.

Communal life, 168; advantages of, 170 .

Communities, animal, 149.

Conditions, primary, of animal life, 106.

Conjugating cells, 28.

Conjugation, 11, 27, 55 .

Contractile vaeuole, 10 .

Coral, brain, 45; island (illus.), 44 ; organ-pipe (illus.), 45 ; red, 45.

Corals, 37-43.

Corynolophus reinhardti (illus.), 124.

Cottony cushion seale (illus.), 142. Conrtship, instincts of, 248 .

Crab, metamorphosis of (illus.), 97; with sea-anemone (illus.), $17 \%$.

Cray-fish, auditory organ of (illus.), 233.

Cricket, anditory organ of (illus.), 234.

Cricket, mole (illus.), 146.

Crinoid (illus.), 305.

Crop, 71.

Crowd of animals, 114.

Crustaceans, ardults and litrvir? (illus.), 195.

Cteniza catifornica, nest of (illus.), 261.

Crcle, life. 78.

Cypselurus (illus.). 131.

Cyst. 15.

Cytoplasm, 3.
Dead-leaf butterfly (illus.), 211.

Death, 103.

Deep-sea angler (illus.), 124.

Defense of the young, adaptations for, $13 \%$.

Degencration, causes of, 197,198 ; human, 200 ; througli quiescence, 193.

Desiccation, 104.

Development, 78 ; continuity of, 83 ; divergenee of, 84 ; embryonic, 80 ; first stages in (illus.), 81 ; laws of, 86 ; metamorphie, 90 ; of flounder (illus.), 100 ; of locust (illus.), 91 ; of vert ebrates, (illus.), 87; post-embryonic, 80 ; significance of facts of, 89 .

Diapheromera femorata (illus.), 209.

Differentiation, 41 ; of structure, 64.

Dimorphism, 42 ; sex, 58.

Diodon hystrix (illus.), 134.

Disinal Swamp fish (illus.), 282.

Distribution, claracter of barriers, to, 288; geographical, 272; influenced by climate, 291; laws of, 274 ; modes of, $296 ;$ mol11tains a bartier to, 293; of Camadian Skipper butterfly (illus.), 273; of cloulerl skipue hutlerfly (illus.), 273; of Erynnis manitoba (illus.), 273 ; sea a harricr to, 288: temperature a barrier to, 290 .

Diverticula, 74 .

Division of labor, 22. 168 .

Dog, pointer (illus.), 256.

Dragon-fly, cye of (illus.), 239 .

Duck, Aretic blaek (illus.), $13 \%$.

Duodenum, 68 .

Duration of life, 101. 
Earthworm, alimentary canal of (illus.), $\% 1$.

Ectoblast, 82.

Eetoderm, 33.

Egg case of Californian barn-door skate (illus.), 140 ; cockroaeh (illus.), 140.

Egg cell, 21, 56.

Egg, fertilized, 35; of bird (illus.), 79 ; of butterfly (illus.), 79 ; of fish (illus.), 79 ; of katydid (illus.), 79 ; of skate (illus.), 79 ; of toad (illus.), 79 .

Electric ray, (illus.), 135.

Elk, hor'ns of (illus.), 148.

Embryology, 64.

Embryonic developinent, 80.

Emmydrichthys vulcanus (illus.), 132.

Endoblast, 82.

Endoderm, 33.

Environment, instinets of, 248.

Epizoanthus paguriphilus, with sea-inemone (illus.), $17 \%$.

Erynnis manitoba, distribution of (illus.), 273.

Eucope (illus.), 42.

Eudorine, $2 \%$

Eudorina elegans (illus.), 28.

E.cocotus (illus.), 131.

Fye of dragon-fly (illus.), 899 ; of jelly-fish (illus.), 238.

Faum, 296; bassalian, 305 ; littoral, 306 ; pelagie, 304.

Fatumal areas of the sen, 304.

Feeding habit of Cahifornian woodpeeker (illus.), 128, 129; of Melanerpes formicivorus bairdii (illus.), 128, 129; instincts of, 244.

Female, 57.
Fish, egg of (illus.), 79 ; embryonic stages of (illus.), 87; -louse (illus.), 188.

Fishes, man-of-war (illus.), 175 ; nest-making habits of, 264 .

Fission, 9 ; binary, 54.

Flagella, 25.

Flagellata, 24.

Flatworm, alimentary canal of (illus.), 70 .

Flounder, development of (illus.), 100 ; ride-eyed (illus.), 100 .

Flying fishes (illus.), 131.

Food, adaptations for securing, 125: necessary to animal life, 106.

Form. primitive, 20 .

Fossil, 18.

Fresh-water animals, binriers affeeting, 294 .

Function, 63.

Fur seal (illus.), 136.

Galapagos Islands, animals of (illus.). 278; locusts of (illus.), 280 .

Gall, giant, of white oak (illus.), 143.

Galls, insect, on leaf (illus.), 144.

Gapes, worm which causes, 60 .

Gastrula, 82.

Gemmule, 35 .

Generalization, 66.

Generation, spontaneous, 51.

Generations, alternation of. 51.

Geographical distribution, 272.

Geometrical larva on branch(illus.), 209.

Crerhonotus scincicauda (illus.), 204.

Giraffe (illus.), 126.

Gizzard, 71. 
Globigerina-ooze, 18.

Globigerina, 16.

Gonium, 25-30.

Gonium pectorale (illus.), 25.

Grasshopper, auditory organ of (illus.), 234 .

Green-leaf insect (illus.), 210.

Gregarina, 13, 182.

Gregarina polymorpha (illus.), 14.

Gregarinidæ, 14.

Gregariousness, 163.

Growth, 78.

Gryllotalpa (illus.), 146.

IIabit, 251.

Habitat, relation of species of, 283. Habits, domestie, $25 \%$.

Habits, nest-making, of birds, 264 ; of fishes, 264 ; of insects, 262 ; of invertebrates, 258; of spiders, 259 ; of vertebrates, 264 .

Hearing, sense of, 232.

Heliospharera actinota (illus.), 19.

Heredity, 89.

Hermaphroditism, 60 .

Hermit-crab, witl the sea-anemone (illus.), 176.

IIibernation, 103.

Hiving honey-bees (illus.), 154.

Holothurian, alimentary canal of (illus.), 70.

11omes, $25 \%$.

Honey-bee (illus.), 150; adult and larva (illus.), 83; leg of (illus.), 151: life history of, 149.

Honey-bees, living a swarm of (illus.), 154.

Host, relation of parasite to, 179 .

Human degeneration, 200.

Humming-bird, nest of rufus (illus.), 265, 266.

Hydra, $3 \%$.
IIydra vulgans (illus.), 38.

IIydrophilus (illus.), 146.

Ifyla regilla (illus.), 145.

Icerya and Vedalia, 121.

Icerya purchasi (illus.), 142.

Ileuin, 68.

Individual, 31.

Indo-African realm, 301.

Inorganic matter, 112.

Insect galls on leaf (illus.), 144 .

Insects, lletamorphosis of, 90 ; nestmaking habits of, 262 ; parasitic, 188.

Instinct, 242 .

Instincts, altruistic, 243 ; classification of, 243 ; concerned with care of the young, 250 ; egoistic, 243 ; of climate, 248 ; of eourtship, 248 ; of environment, 248 ; of feeding, 244; of play, 247 ; of reproduction, 249 : of self-defense, 245 ; variability of, 251 .

Intellect, 254 .

Intestiue, 68.

Invertebrates, nest-naking labits of, 258 .

Irritability, 8, 240 .

Islanrl, coral (illus.). 44.

Itch-mite (illus.), 192.

Jack-lahbits, showing variation (illus.). 281 .

Jay, Canada (illus.), 138.

Jejunum, 68.

Jelly-fish, eye of (illus.), 238.

Jelly-fishes, 37 ; colonial, 45.

Kallima (illus.), 211.

Kangaroo (illus.), 139.

Katydid, egg of (illus.), 79.

Lady-bird beetles (illus.), 214 . 
Lady-fish, metanor phosis of (illus.), 98.

Lagoon (illus.), 44 .

Larva, 92 ; of butterfly pupating (illus.), 94.

Leaf-eutting ant mimieked by treehoppers (illus.), 220.

Lemur (illus.), 302.

Lemur varius (illus.), 302.

Lemurian realm, 302.

Lepas, adult and larva (illus.), 195; metamorphosis of (illus.), 101.

Lerema accius, distribution of (illus.), 273.

Lernoeocerc (illus.), 188.

Life eyele, $7 \mathrm{~s}$.

Life, eommunal, 168 ; duration of, 101 ; lrimitive, 21 ; proeesses, 21 ; soeial, 149.

Light, influence of, on animals, $23 \%$.

Lipeureus densus (illus.), 188.

Littoral fanna, 306.

Lizard, alligator (illus.), 204.

Lizzia koellikeri, eye of (illus.). 238.

Locust, post-embryonie develop. ment of (illus.), 91.

Loeusts of Galipagos Islandis (illus.), 280.

Louse, sucking (illus.), 188.

Macropus rufus, 139.

Mad Tom (illus.), 132.

Male, 57.

Mammals, cale of young of, 268 .

Manatee (illus.), $27 \%$.

Man-of-war, Portuguese (illus.), 175.

Mantis (illıs.), $12 \%$.

Mary-celled animal, 2.

Narine Protozoa, 15.
Marks, reeognition, 22, 129, 223.

Meduse, 41.

Negalops, 97 .

Melanerpes formicivorus bairdii, feeding habit of (illus.), 128, 129.

Nembraeida minicking Sauba ant (illus.), 220 .

Mesoder'm, 33.

Metamorphosis, 90 ; of Albula rulpes (illus.), 98: of Anosia plexippus (illus.), 92: of barnaele (illus.), 101 ; of butterfly (illus.), 92; of crab (illus.), 97; of inseets, 90; of lady-fish (illus.), 98; of Lepas (illus.), 101; of mosquito (illus.), 93 ; of sea-urchin (illus.), 96: of sworl-fish (illus.), 99; of toad, 94. (illus.), 95: of Xiphias gladius (illus.), 99.

Metazoa, 32.

Metridium dianthus (illus.), 43.

Miero-organism, 16.

Migration of lemming, 118: of loeust, 118.

Minickry, 218.

Mind, 255 .

Mining-bee, nest of (illus.), 160 .

Molt, 91.

Momareh butterfly (illus.), 219 ; minicked by Vieeroy buttertiy (illus.), 219.

Monogany, 135.

Mosquito, auditor organ of (illus.). 285 ; lead of (illus.), 127; netramorphosis of (illus.), 93 ; young stages of (illus.), 147.

Moth, cankerworm (illıs.), 59.

Mountains as barrier's to distribution, 293.

Mouth parts of mosquito (illus.), 127. 
Mouse-fish in gulf-weed (illus), 208. Mit. Orizaba (illus.), 300.

Multiplication, 50 ; of animals, 114: simplest method of, 53; slightly complex methols of, 54 . Murres, Pallas's (illus.). 165.

Mussel, alimentary canal of (illus.), 72.

Nutual aid, 163.

Narcine brasiliensis (illus.), 135.

Natural selection, $11 \%$.

Neotropical realm, 301.

Nerve cells, 240.

Nerve fibers, 240.

Nest-making habits of birts, 264 ; of fishes, 264; of insects, 262; of invertebrates, 258 ; of spiders, 259 ; of vertebrates, 264 .

Nest of Baltimore oriole (illus.), 267 ; of beavers (illus.), 269 ; of Californian bush-tit (illus.), 270 : of Cteniza californica (illus.), 261 ; of pocket-gopher (illus.), 271 ; of rufus liumming-bird (illus.), 265, 266 ; of tailor-bird (illus.), 268 ; of trap-rloor spider (illus.), 261; of turret-spider (illus.), 262.

Nokce (illus.), 132.

Nomeus gronovii (illus.), 175.

North Temperate realin, 299.

Nuclear membrane, 3.

Nucleus, 3.

Obelia, alimentary sac of (illus.), 69.

(Esophagne, 67.

Omasum, $6 \%$.

One-celled animals, 2.

Organ, 63 ; auditory, of eray-fish (illus.), 233; of cricket (illus.),
234; of grasshopper (illus.), 234 ; of mosquito (illus.), 235 ; of mollusk (illus.), 233.

Organic matter, 112.

Organs, auditory, 232; of smell, 229 ; of sound-making, 235 ; of taste, 228; of touch, 226; specialization of, 66 ; vestigial, 147. Oriole, Baltimore, nest of (illus.), $26 \%$.

Ornithotomous sutorius, nest of, 268.

Osprey Falls (illus.), 285.

Otolith, 232.

Ox, alimentary canal of (illus.) 67. Oxygen, necessary to animal life, 107.

Pagurus (illus.), 176.

Pandorina, 26.

Pandorina sp. (illus.), 26.

Pandorina morum (illus.), 27.

P'apilio, chrysalid of (illus.), 205.

Papilla, tactile, of skin of man

(illus.), $22 \%$.

Papilla, $6 \%$.

I'aramacium, 9.

Peremacium aurelia (illus.), 10.

I'aramocium creudatum (illus.), 11.

Paramccium plutorimum. (illus.), 11.

Parasite of catcrpillar (illns.), 190 ; relation to host, 179.

Parasites, simple structure of, 181.

Parasitism, 179; kinds of, 180.

Parthenogenesis, 60.

Patagonian realm, 302.

Pediculus (illus.), 188.

Pelagic fanna, 304.

Pelican, brown (illus.), 125.

Peneus, adult and larva (illus.), 195. 
Perisoreus canadensis (illus.), 138. Pharynx, 71.

Phlegethontius carolina, larva of (illus.), 215.

Phrynosoma blainvillei(illus.), 131. Phyllium (illus.), 210.

Phyllopteryx (illus.), 212.

Physalia (illus.), 175.

Physiology, 64 .

Physoptora (illus.), 47.

Pocket-gopher, nest of (illus.), 271.

Pointer dog (illus.), 256.

Polistes, parasitized by Stylops (illus.), 192.

Polygamy, 59.

Polymorphism, 42.

Polyps, 37.

Polystomella strigillata (illus.), 17. Poreupine-fish (illus.). 134.

Post-embryonie development. 80 .

Pigeon horn-tail (illus.), 191.

Pipe-fish (illus.), 212.

Planaria, alimentary canal of (illus.), 70.

Plankton, 304.

Plants, difference between animials and, 111.

Platophrys lunatus (illus.), 100.

Play, instincts of, 247.

Pluteus, 96.

Prateocial, 140.

Prawn, adult and larva (illus.), 195.

Praying-horse (illus.), $12 \%$.

Pressure, a condition of animal life, 109.

Primitive form, 20.

Primitive life, 21.

Prionus, lurva of (illus.), 146.

Proeesses, life, 21.

Promethea moth (illus.), 231.

Prophysema primordiale (illus.), 34.
Proteetive resemblanee, 201.

Protoplasm, 3; chemical eoustitution of, 4 ; physical constitution of, 4 .

Protozoa, 1 ; colonial, 24 ; marine, 15.

Psaltriparus minimus, nest of (illus.), 270.

Pseudopod, 5.

Pterophryne histrio in Sargassum (illus.), 208.

Pupa, 93.

Puss moth, larva of (illus.), 216.

Quiescence, degeneration through, 193.

Rabbit, embryonic stages of (illus.), $8 \%$

Radiolaria, 16.

Radiolaria-ooze, 19.

Raja binoculata (illus.), 140.

Realm, Aretie, 29r; Australian, 308 ; Indo-African, 301 ; Lemurian, 302: Neotropienl, 301; North Temperate, 299 ; of animal life, 297: Patagonian, 302; Sonth Ameriean, 301.

Realms, subordinate, 303 .

liason, 251 .

leeognition marks, 22, 129, 223 .

licetum, 68 .

Reflex aetion, 241 .

Renora (illus.), 173.

Remora remora (illus.), 125.

Reproduetion, 9, 50; instincts of, 249.

Reproduetive cells, 28,55 .

Resenblanee, aggressive, 202 ; general proteetive, 202 ; protective, 201 ; special protective, 207 ; v riable proteetive, 204 . 
Respiration, 7.

Resting spore, 28.

Retieulum, 6r.

Rhizocrinus loxotensis (illus.), 305.

Rivalry, adaptations for, 135 .

Rookeries, fur-seal (illus.), 169.

Rumen, 67.

Secculina (illus.), $18 \%$.

Saceulina, adult and larva (illus.). 195.

Salamander, embryonic stages of (illus.), $8 \%$

Saliva, $6 \%$.

Salnon leaping (illus.), 289.

Salmo viridens (illus.), 145.

Sareoptes (illus.), 192.

Sauba, ant mimicked by Membracide (illus.), 220 .

Scale, red orange (illus.), 196.

Schilbeodes furiosus (illus.), 132.

Scorpion (illus.), 12\%.

Scorpion-fish (illus.), 132.

Sen, a barrier to distribution, 288.

Sea, famal areas of, 304.

Sea-anemone. 3\%; with algae in bouly (illus.), 178.

Sea-cow (illus.), $27 \%$

Sea-cueunber, alimentary canal of (illus.). 50 .

Sea-squirt (illus.), 194.

Sea-urchin, metamorphosis of (illns.), 96.

Sea-urehins (illus.), 259.

Seal, fur (illus.), 136; pups killed by parasite (illus.), 186; rookeries (illus.), 169.

Selection, artificial, 120; natural, $11 \%$

Self-defense, alaptations for, 128 ; instincts of, 245 .

Sensation, 8.
Senses, speeial, 224 ; of the simplest animals, 225.

Sensorium, 241.

Serphus (illus.), 141.

Sex, 57 ; object of, 57 ; dimorphism, 58.

Shark-clinging fish (illus.), 125.

Sheep, bighorn (illus.), 167; Rocky Mountain (illus.). 167.

Sight, sense of, $23 \%$.

Simplest animals, life of, 1.

Siphonophora, 46.

Skate, cgg case of California barndoor (illus.), 140; egg of (illus.), 79.

Skin of man, tactile papilla of (illus.), $22 \%$.

Smell, sonse of, 229.

Smelling organs, 229.

Smelling pits of leaf-eating beetle (illus.), 230.

Social life, 149.

Sound-making, 235; organs, 235.

Sonth Ameriean realm, 301.

Specialization, 66 ; of organs, 66 .

Special senses, 224.

Species, altered by adaptation to new eonditions, 276; debarred by harriers, 274 : debatred by inability to maintain their ground, 275 ; definition of, 279 ; relation of, to labitat, 283.

Sperm cell, 35, 56.

Sphinx moth, larva of (illus.), 215.

Spicules, sponge, 33.

Spiders (illus.), 212; nest-making habits of, 259 .

sponges, 32.

sjongin, 36.

Spontaneous generation, 51 .

Spore, 15, 52 ; resting, 28.

Sting-1ay (illus.), 133. 
Strueture, 63 ; differentiation of, 64 . Struggle for existence, 116. Stylops parasitizing I'olistes (illus.), 192.

Sub-species, definition of, 282.

Surroundings, adaptations coneerned with, 143.

Swallow-tail butterfly, chrysalid of (illus.), 205 .

Sword-fish, netamorphosis of (ilIus.), 99.

Symbiosis, 172, 175 .

Syngamus trachealis (illus.), 60.

Systematic zoölogy, 64 .

Tactile organs, 226 .

Tactile papilla of skin of man (illus.), $22 \%$.

Tadpole, 94.

Trenia solium (illus.), 183.

'Tailor-birt, nest of (illus.), 268.

Tape-worm (illus.), 183.

Taste bucls of eall (illus.), 229 .

Taste organs, 228.

Taste, sense of, 228.

Temperature a barrice to distribution, 290 ; a eondition of animal life, 108 .

Tentrele, 37.

Termite, 158. (illus.), 159.

Terrifying appratunces, 212.

Thatessot tumetor (illus.), 191.

Troud, egg of (illus.), ra; holned (illus.), 131: metamorphosis of, 94, (illus.). 95.

Torperto (illus.), 185.

T'ortoise, embryonic stages of (illns.), $8 \%$.

Touch, sense of, 226.

Trap-door spider nest (illus.). 261. Tree-hoppers mimicking leaf-cutting ant (illus.), 220.
Tree-trad (illus.), 145.

Tremex columba (illus.), 191.

Trichechus Tatirostris (illus.), $27 \%$.

Trichina spiralis (illus.), 184.

Tripoli, 19.

Trochitus rufus, nest of (illus.), $265,266$.

Trout, rainbow, head of (illus.), 145.

Two Ocean Pass (illus.), 28\%.

Tunicate (illus.), 194.

Turret-spider, nest of (illus.), 262.

Typhlichthys subterraneus (illus.), 282.

Uncinaria, killing fur-seal pups (illus.), 186.

Uria Tomvira arra (illus.), 165.

Urolophus goodei (illus.), 133.

Vacuole, 10 ; contractile, 10.

Variety, definition of, 282.

Vedratio and Icerya. 121.

Vertebrates, early stages in development of (illus.), 8i; nest-making labits of. 264; parasitic. 193. Tespu (illus.). 162: nest of (illus.), 163.

Testigial organs, $14 \%$.

Vieeroy butterfly minicking Monarch butterfly (illus.), 210 .

Toice, 236.

Volvocina, 24.

lohrox, 28.

Tolrox globator (illus.). 29.

Voliner minor (illus.), 29.

Torticella. 12.

I'orticella microtoma (illus.), 12.

Walking-stick inseet (illus.). 209.

Warning colors, 212.

Walrns, Atlantic (illus.), 298. 
Wasps, social, 161.

Water - beetle (illus.), 146; bug, giant (illus.), 141.

Whippoorwill (illus.), 203.

Woodpecker, Californian, feeding habit of (illus.), 128, 129 .

Xiphias gladius, metamorphosis of (illus.), 99.

Yellow-jacket (illus.), 162.

Yolk, 80.

Young, adaptations for defense of, 137 ; care of the, 250,257 ; number of, 61 .

Zoea, 97.

Zoögeography, 272.

Zoölogy, systematic, 64 . 



\section{TWENTIETH CENTURY TEXT-BOOKS.}

\section{Plant Relations.}

\section{NOW READY.}

A First Book of Botany. By John Merle Coulter, A. M., Ph. D., Head of Department of Botany, University of Chicago. I2mo. Cloth, \$I.Io.

\section{Plant Structures.}

A Second Book of Botany. By John Merle Coulter, A. M., Ph. D. I2mo. Cloth, \$1.20.

\section{Plant Studies.}

An Elementary Botany. By John M. Coulter, A. M., Ph. D. I2mo. Cloth, \$1.25.

Plants.

A Text-Book of Botany. By John Merle Covlter, A. M., Ph. D. 12 mo. Cloth, \$r.80.

\section{A History of the American Nation.}

By Andrew C. Mclaughlin, A. M., LL. B., University of Michigan. I2mo. Cloth, \$r.40.

English Texts. I2mo. Cloth, 50 cents ; boards, 40 cents.

Dryden's Palamon and Arcite. Edited by George M. Marshall, Ph. B., University of Utah.

Shakspere's Macbeth. Edited by RICHARD Jones, Ph. D., Vanderbilt University.

The Sir Roger de Coverley Papers. Edited by Franklin T. Baker, A. M., Columbia University, and Richard JONES, Ph. D.

Selections from Milton's Shorter Poems. Edited by Frederic D. Nichols, University of Chicago.

Macaulay's Essays on Milton and Addison. Edited by Geokge B. AITon, A. M., State Supervisor of High Schools, Minnesota.

Burke's Speech on Conciliation with America. Edited by Wilinam I. Crane, Steele High School, Dayton, Ohio.

Coleridge's Rime of the Ancient Mariner. Edited by Pelham Edgar, B. A., Ph. D., Victoria College.

George Eliot's Silas Marner. Edited by J. Rose CnLby, Ph. D., Illinois State Normal University, and Richard Jones, Ph. D. Cloth, 60 cents; boards, 45 cents.

\section{Animal Life.}

A First Book of Zoölogy. By David S. Jordan, M. S., M. D., I'h. D., LL. D., President of Leland Stanford Junior University, and VerNoN L. KELLOGG, M. S., Leland Stanford Junior University. I mo. Cloth, \$I.20.

\section{The Elements of Physics.}

By C. Hanford Henderson, Ph. D., Principal of Pratt High School, Frooklyn, and Joun F. Woodhull, A. M., Professor of Physical Science, Tcachers' College, Columbia University.

\section{Physical Experiments.}

A Laboratory Mamual. By John F. Woodhull, Ph. D., and M. B. Van Arsdale, Instructor in Physical Science in Horace Mann School and Assistant in T'eachers' College.

The Elementary Principles of Chemistry.

By Abram Van Eps Young, Ph. B., Northwestem University, Evanston, Ill.

D. APPLE'TON AND COMPANY, NEW YORK.




\section{TWENTIETH CENTURY TEXT BOOKS.}

The closing years of the present century are witnessing the beginning of a remarkable awakening of interest in our American educational problems. There has been repeated and elaborate discussion in every part of our land on such topics as the coordination of studies, the balancing of the different contending elements in school programmes, the professional training of teachers, the proper age of pupils at the different stages of study, the elimination of pedantic and lifeless methods of teaching, the improvement of text books, uniformity of college-entrance requirements, and other questions of like character.

In order to meet the new demands of the country along the higher plane of educational work with a complete and correlated series of text books fully embodying the latest advances in our education, the Twentieth Century 'Text Books are now offered.

At every step in the planning of the series care has been taken to secure the best educational advice, in order that the books issued may really meet the increasing demand that now comes alike from academies, high schools, and colleges for text books that shall be pedagogically suitable for teachers and pupils in the schools, sound in modern scholarship, and adequate for college preparation. 
The editors and the respective authors of the Twentieth Century Text Books have been chosen with reference to their qualifications for the special work assigned to them. These qualifications are, first, that the author should have a thorough knowledge of his subject in its latest developments, especially in the light of recent educational discussions ; second, that he should be able to determine the relative importance of the subjects to be treated in a text book; third, that he should know how to present properly his topics to the ordinary student.

The general editorial supervision of the series has been placed in the hands of Dr. A. F. Nightingale, Superintendent of High Schools, Chicago, and Professor Charles H. Thurber, of the University of Chicago, men thoroughly conversant with every phase of education.

The offer of a complete series of text books for these higher grades of schools, issued under auspices so favorable, concentrating and co-ordinating such a force of able writers all working with one end in view, is an event worthy of the twentieth century, and a good omen for the educational welfare of the future.

Nearly one hundred volumes are in preparation, and several are now ready. Others will follow rapidly, the issue of which will be duly announced.

D. APPLETON AND COMPANY, NEW YORK. 


\section{FRANK M. CHAPMAN'S BOOKS.}

\section{Bird Studies with a Camera.}

With Introductory Chapters on the Outfit and Methods of the Bird Photographer. By Frank M. Chapman, Assistant Curator of Vertebrate Zoology in the American Museum of Natural History ; Author of " Handbook of Birds of Eastern North America" and "Bird-Life." Illustrated with over Ioo Photographs from Nature by the Author. 12 mo. Cloth, \$1.75.

Bird students and photographers will find that this book possesses for them a unique interest and value. It contains fascinating accounts of the habits of some of our common birds and descriptions of the largest bird colonies existing in eastern North America; while its author's phenomenal success in photographing birds in Nature not only lends to the illustrations the charm of realism, but makes the book a record of surprising achievements with the camera Several of these illustrations have been described by experts as "the most remarkable photographs of wild life we have ever seen." The book is practical as well as descriptive, and in the opening chapters the questions of camera, lens, plates, blinds, decoys, and other pertinent matters are fully discussed.

Bird-Life.

A Guide to the Study of our Common Birds. With 75 full-page uncolored plates and 25 drawings in the text, by ERNEST SETON Tномрson. Library Edition. I zmo. Cloth, $\$ 1.75$.

The Same, with lithographic plates in colors. 8vo. Cloth, \$5.00.

TEACHERS' EDITION. Same as Library Edition, but containing an Appendix with new matter designed for the use of teachers, and including lists of birds for each month of the year. I $2 \mathrm{mo}$. Cloth, $\$ 2.00$.

TEACHERS' MANUAL. To accompany Portfolios of Colored Plates of Bird-Life. Contains the same text as the Teachers" Edition of "Bird-Life," but is without the 75 uncolored plates. Sold only with the Portfolios, as follows:

Portfolio No. I.- Permanent Residents and Winter Visitants. 32 plates.

Portfolio No. II.-March and A pril Migrants. 34 plates.

Portfolio No. III.-May Migrants, Types of Birds' Eggs, Types of Birds' Nests from Photographs from Nature. 34 plates.

Price of Portfolios, each, \$1.25; with Manual, \$2.00. The three Portfolios with Manual, $\$ 4.00$.

Handbook of Birds of Eastern North America. With nearly 200 Illustrations. I $2 \mathrm{mo}$. Library Edition, cloth, $\$ 3.00$; Pocket Edition, flexible morocco, $\$ 3.50$.

D. APPLETON AND COMPANY, NEW YORK. 


\section{APPLETON AND COMPANY'S PUBLICATIONS.}

\section{FAMILIAR LIFE IN FIELD AND'FOREST. By F. Schuyler Mathews. Uniform with "Familiar Flow- ers," "Familiar Trees," and "Familiar Features of the Road- side." With many Illustrations. I2mo. Cloth, \$I.75.}

The great popularity of Mr. F. Schuyler Mathews's charmingly illustrated books upon flowers, trees, and roadside life insures a cordial 1eception for his forthcoming book, which describes the animals, reptiles, insects, and birds commonly met with in the country. His book will be found a most convenient and interesting guide to an acquaintance with common wild creatures.

\section{FAMILIAR FEATURES OF THE ROADSIDE. \\ By F. SCHuYler Mathews, author of "Familiar Flowers of} Field and Garden," "Familiar Trees and their Leaves," etc. With I 30 Illustrations by the Author. I2mo. Cloth, 1.75.

" Which one of us, whether afoot, awheel, on horseback, or in comfortable carriage, has not whiled away the time by glancing about? How many of us, however, have taken in the details of what charms us? We see the flowering fields and budding woods, listen to the notes of birds and frogs, the hum of some big burmblebee, but how much do we know of what we sense? These questions, these doubts have occurred to all of us, and it is to answer them that Mr. Mathews sets forth. It is to his credit that he succeeds so well. He puts before us in chronological order the flowers, birds, and beasts we meet on our highway and byway travels, tells us how to recognize them, what they are really like, and gives us at once charming drawings in words and lines, for Mr. Mathews is his own illustrator."-Boston fournal.

\section{FAMILIAR TREES AND THEIR LEAVES.}

By F. SChUYLER Mathews, author of "Familiar Flowers of Field and Garden," “The Beautiful Flower Garden," etc. Illustrated with over 200 Drawings from Nature by the Author, and giving the botanical names and habitat of each tree and recording the precise character and coloring of its leafage. I2mo. Cloth, \$1.75.

"It is not often that we find a book which deserves such unreserved commendation. It is commendable for several reasons : it is a book that has been needed for a long time, it is written in a popular and attractive style, it is accurately and profusely illustrated, and it is by an authority on the subject of which it treats." - Public Opinion.

\section{FAMILIAR FLOWERS OF FIELD AND GARDEN. By F. SCHUyler Mathews. Illustrated with} 200 Drawings by the Author. I2mo. Library Edition, cloth, \$1.75; l'ocket Edition, flexible morocco, \$2.25.

"A book of much value and interest, admirably arranged for the student and the lover of flowers. .. The text is full of compact information, well selected and interestingly presented. . . It scems to us to be a most attractive handbook of its kind." -New Iork Sun.

D. APPLETON AND COMPANY, NEW YORK. 


\section{FOR NATURE LOVERS AND ANGLERS.}

\section{Familiar Fish: Their Habits and Capture.}

A Practical Book on Fresh-Water Game Fish. By Eugene McCarthy. With an Introduction by Dr. David Starr Jordan, President of Leland Stanford Junior University, and numerous Illustrations. I 2 mo. Cloth, \$I.5O.

This informing and practical book describes in a most interesting fashion the habits and environment of our familiar freshwater game fish, including anadromous fish like the salmon and sea trout. The life of a fish is traced in a manner very interesting to Nature lovers, while the simple and useful explanations of the methods of angling for different fish will be appreciated by fishermen old and young. As one of the most experienced of American fishermen, Mr. McCarthy is able to speak with authority regarding salmon, trout, ouananiche, bass, pike, and pickerel, and other fish which are the object of the angler's pursuit. His clear and practical counsel as to Hy-casting, and rods and tackle and their use, and his advice as to outfits and the various details of camp life, render his book a most useful companion for all sportsmen and campers. Dr. David Starr Jordan has read the manuscript, and has lent the weight of his approval by writing an introduction. The book is profusely illustrated with pictures and serviceable diagrams.

D. APPLETON AND COMPANY, NEW YORK. 



DEC 031930

\section{Date Due}

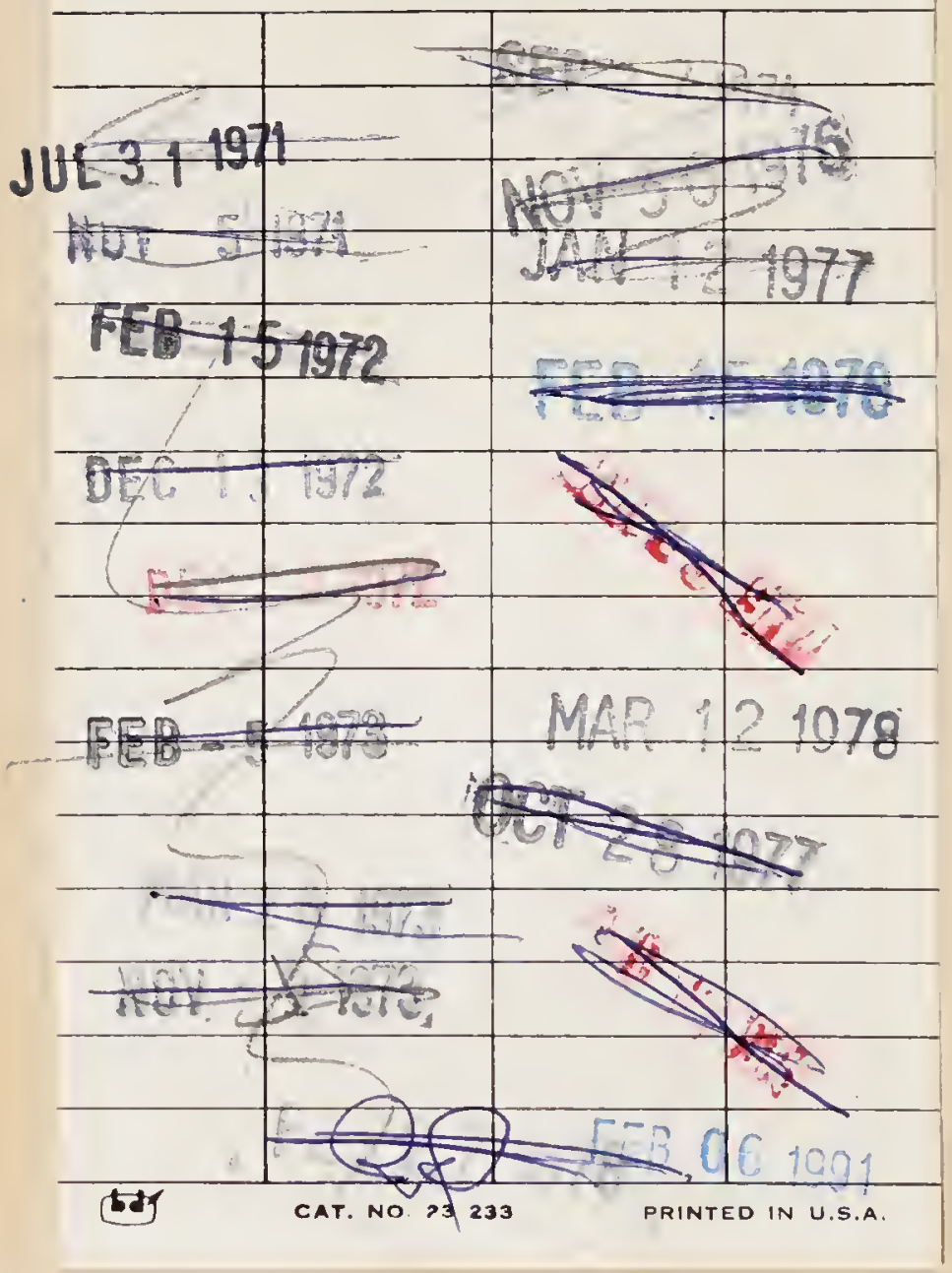




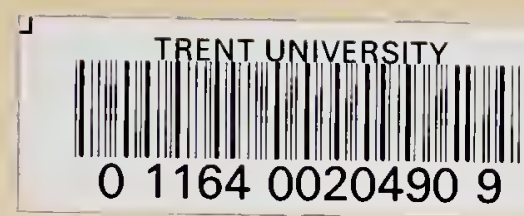

QL48 .J83 1900

Jordan, David Starr

... Animal .1ife

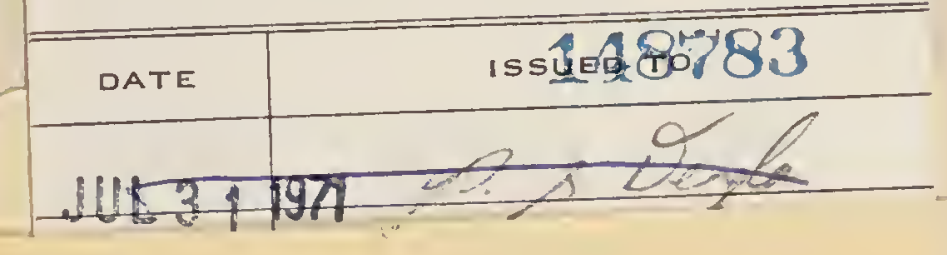




\section{Gist, binn, sto}

:

40 S. $=1$

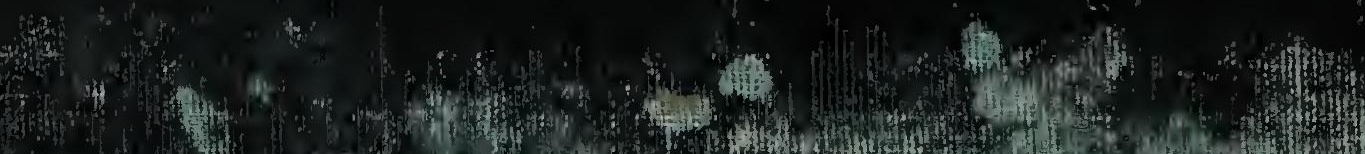

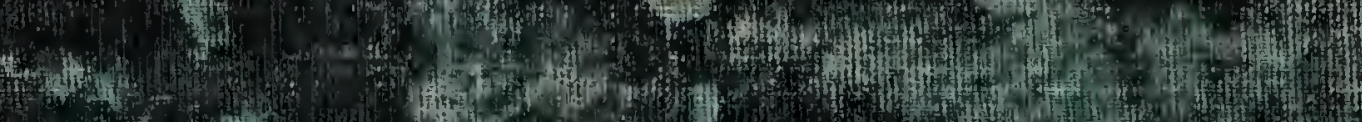
(152) 4. 